\title{
A RELEVÂNCIA DO ELEMENTO SUBJETIVO NA FRAUDE DE EXECUÇÃO
}

Tese de Doutorado apresentada à Banca Examinadora da Faculdade de Direito da Universidade de São Paulo, como exigência parcial para a obtenção do título de Doutor em Direito, sob orientação do Prof. Dr. Walter Piva Rodrigues

FACULDADE DE DIREITO DA USP

SÃO PAULO

2010 
BANCA EXAMINADORA: 


\section{AGRADECIMENTOS}

Agradeço ao meu orientador, Professor Walter Piva Rodrigues, pela antiga amizade, pela esperança em mim depositada e por todas as oportunidades que me tem proporcionado.

Ao Professor José Ignacio Botelho de Mesquita, eterno mestre e amigo, por toda a sua disponibilidade e paciência para o debate e a reflexão sobre o tema.

Agradeço aos Professores Carlos Alberto Carmona e Carlos Alberto de Salles pelas valiosas sugestões feitas no exame de qualificação.

À minha amiga Ana de Lourdes Coutinho por chamar minha atenção para a questão do elemento subjetivo na fraude de execução, em razão das discussões sobre o tema no Tribunal de Justiça de São Paulo.

Agradeço, também, ao Professor José Lebre de Freitas, pelo esclarecimento de diversas dúvidas quanto ao direito português vigente.

Registro também minha gratidão à minha irmã, Renata, e aos meus amigos, Samantha, Lúcia, Nicole, Tomás, Jaime, Marcus e Cleyton pelas inestimáveis contribuições ao longo do trabalho e a todos os amigos e colegas do escritório que tornaram possível o desenvolvimento desta tese.

Agradeço, ainda, aos meus pais Tânia e Sylvio e à D. Edda que tanto incentivaram o desenvolvimento desta tese.

Por fim, agradeço à minha esposa, Isabel, não só pela profunda alegria que me faz sentir por estar ao meu lado, mas por todo o apoio incondicional e a ajuda imprescindível para a conclusão desta tese. 


\section{SUMÁRIO}

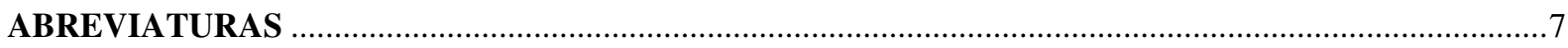

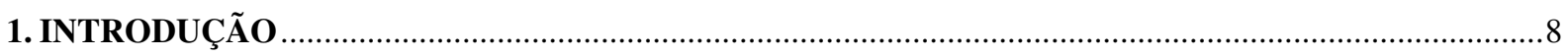

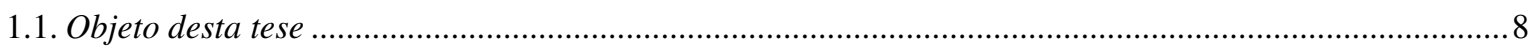

1.2. Organização e desenvolvimento do trabalho ................................................................................... 13

2. FRAUDE DE EXECUÇÃO: TERMINOLOGIA, PREMISSAS CONCEITUAIS E HIPÓTESES

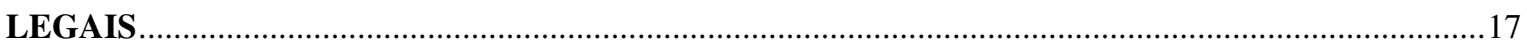

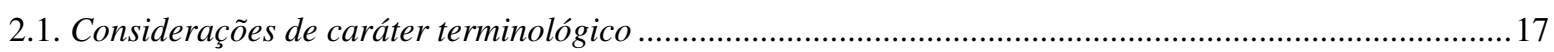

2.2- Em torno do conceito da fraude de execução ........................................................................................20

2.3. As hipóteses da fraude de execução na legislação atual...........................................................................22

2.3.1. Pendência de ação fundada em direito real ............................................................................28

2.3.2. Pendência de ação que possa reduzir o devedor à insolvência....................................................32

2.3.3. Outras hipóteses expressamente previstas em lei.........................................................................35

2.3.3.1. Quitação pelo devedor de débito de terceiro penhorado...................................................36

2.3.3.2. Alienação de bens dentro do termo legal da falência .......................................................37

2.3.3.3. Alienação de bens após a inscrição de crédito tributário como dívida ativa ........................39

2.3.3.4. Transferência do bem de família para imóvel mais valioso?............................................41

2.3.3.5. Alienação de bem penhorado, arrestado ou sequestrado? ..................................................43

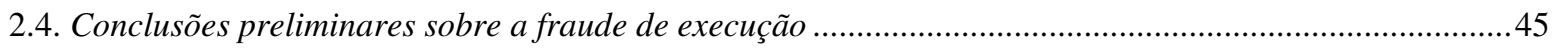

3. O ESTADO DA QUESTÃO: O ELEMENTO SUBJETIVO COMO REQUISITO PARA CONFIGURAÇÃO DA FRAUdE DE EXECUÇÃO E SUA FEIÇÃO CONFORME O

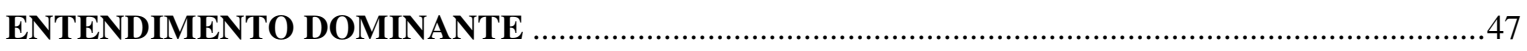

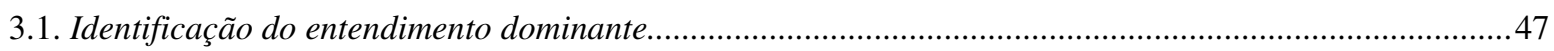

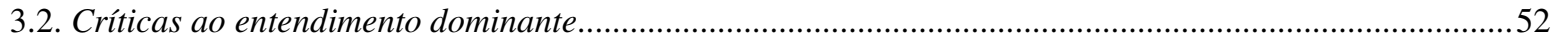

4. ANÁLISE HISTÓRICA DA FRAUDE DE EXECUÇÃO NO DIREITO BRASILEIRO: BUSCA DA ORIGEM DO PROBLEMA E RESGATE DA FEIÇÃO E DA RELEVÂNCIA ORIGINAIS DO ELEMENTO SUBJETIVO

4.1. Primeiro período (1850-1890): surgimento e consolidação das hipóteses da fraude de execução nas leis do processo civil e do processo comercial e sua relação com as normas do registro imobiliário ......57

4.2. Segundo período (1890-1939): a legislação federal, os códigos estaduais e a gradual conquista do paralelismo entre as regras processuais e registrárias

4.3. Terceiro período (1939-1973): o Código de Processo Civil de 1939 e o rompimento do paralelismo conquistado no período anterior .

4.4. Quarto período (1973-2009): o Código de Processo Civil de 1973, a manutenção das alterações de 1939 e a inserção, pelas reformas processuais de 1994, 2002 e 2006, de normas incompativeis com o sistema adotado originalmente pelo código 


\section{CONFRONTO ENTRE O ENTENDIMENTO DOMINANTE E A HIPÓTESE PROPOSTA À LUZ}

\section{DA LEGISLAÇÃO ATUAL}

5.1. Irrelevância do elemento subjetivo nos casos do inciso I do artigo 593 do Código de Processo Civil e naqueles do inciso II em que a notícia da pendência da ação conste de registro público

5.2. Irrelevância do elemento subjetivo do devedor......

5.3. Investigação do elemento subjetivo em sua feição original.

5.4. Inexistência de regra excepcional de distribuição do ônus da prova

6. O EFEITO DO RECONHECIMENTO DA FRAUDE DE EXECUÇÃO: INOPONIBILIDADE DO LIMITE PATRIMONIAL DO TERCEIRO À ATIVIDADE EXECUTIVA

\section{AS CINCO VARIÁVEIS DA FRAUDE DE EXECUÇÃO E SUA RELAÇÃO COM O ELEMENTO} SUBJETIVO: PROPOSTA DE METODOLOGIA PARA ANÁlISE DA CONFIGURAÇÃo DE FRAUDE DE EXECUÇÃO.

7.1. Ação fundada em direito real ou que possa reduzir o devedor à insolvência ......................................... 153

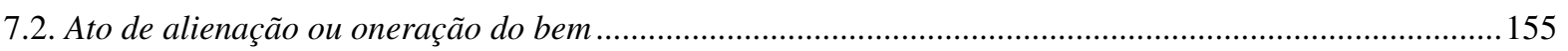

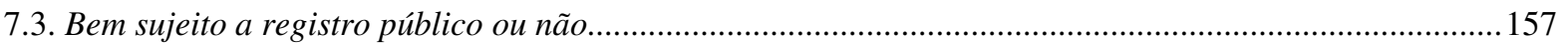

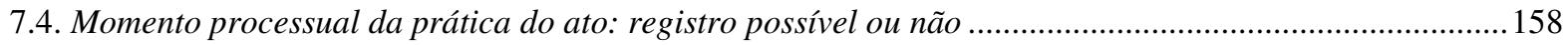

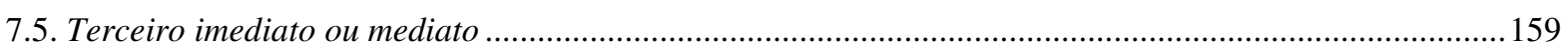

7.6. Delimitação dos casos em que o elemento subjetivo é relevante e sugestão de critério - extraído do ordenamento jurídico - para aferir sua presença .....

RESUMO

ABSTRACT.

RIASSUNTO 
Apêndice 2 - Relatório da análise da jurisprudência do Superior Tribunal de Justiça sobre o tema da súmula 375

Apêndice 3 - Figuras.

Apêndice 4 - Propostas de alterações legislativas ....

ÍNDICE DE FONTES 236 


\section{ABREVIATURAS}

$1^{\circ}$ TAC-SP - Primeiro Tribunal de Alçada Civil do Estado de São Paulo AI - Agravo de Instrumento

Apel. - Apelação

Art. - Artigo

Câm. - Câmara

CC - Código Civil - Lei n. ${ }^{\circ}$ 10.406, de 10 de janeiro de 2002

CPC - Código de Processo Civil - Lei n. ${ }^{\circ}$ 5.869, de 11 de janeiro de 1973

CP - Código Penal - Decreto-Lei n. ${ }^{\circ}$ 2.848, de 7 de dezembro de 1940

CTN - Código Tributário Nacional - Lei n. ${ }^{\circ}$ 5.172, de 25 de outubro de 1966

Dec.-lei - Decreto-lei

Des. - Desembargador

j. - julgado em

Min. - Ministro

RE - Recurso Extraordinário

Rel. - Relator

REsp. - Recurso Especial

RJTJSP - Revista de Jurisprudência do Tribunal de Justiça de São Paulo

RT - Revista dos Tribunais

RTJ - Revista Trimestral de Jurisprudência

STF - Supremo Tribunal Federal

STJ - Superior Tribunal de Justiça

TJPR - Tribunal de Justiça do Paraná

TJSP - Tribunal de Justiça de São Paulo

T. - Turma 


\section{1- INTRODUÇÃO}

\section{1- Objeto desta tese}

É relevante para a configuração das hipóteses de fraude de execução previstas no artigo 593 do CPC a boa ou a má-fé das pessoas nelas envolvidas?

Diferentemente da maioria das questões jurídicas, em que os intérpretes se dividem em duas correntes antagônicas, com a eventual formação de terceira corrente intermediária, a pergunta acima formulada provoca na doutrina e na jurisprudência as mais diversas respostas, que podem ser ordenadas conforme a maior ou menor relevância que atribuam ao elemento subjetivo para a configuração da fraude de execução.

Num extremo, encontraríamos o entendimento, outrora majoritário, que defende a absoluta irrelevância da boa ou má-fé dos envolvidos para a configuração das hipóteses de fraude de execução. ${ }^{1}$

No outro extremo, estaria o entendimento, atualmente dominante, que sustenta a total relevância do elemento subjetivo, não havendo fraude de execução sem que tanto o devedor quanto o terceiro - seja ele imediato ou mediato ${ }^{2}$ - estejam de má-fé. ${ }^{3}$

\footnotetext{
${ }^{1}$ Nesse sentido, Pontes de Miranda: "toda indagação da má-fé é estranha à concepção do instituto, em qualquer dos incisos do art. 593. (...) É preciso que não se intrometa no assunto da fraude à execução o elemento da culpa, nem, tão-pouco, do lado do adquirente, o elemento da má-fé." (MIRANDA, Francisco Cavalcanti Pontes de. Comentários ao Código de Processo Civil. Atualização legislativa por Sérgio Bermudes. 2. ed. rev. e aumen. Rio de Janeiro: Forense, 2001. t. 9, p. 344-345); Liebman: "a lei dispensa a prova do elemento subjetivo da fraude, do consilium fraudis. A intenção fraudulenta está in re ipsa." (LIEBMAN, Enrico Tullio. Processo de execução. Com notas de atualização do Prof. Joaquim Munhoz de Mello. 5. ed. São Paulo: Saraiva, 1986. p. 108); José Sebastião de Oliveira: "na configuração da fraude de execução não há que se provar que o devedor agiu dolosamente, alienando o único bem que possuía, ou então que o adquirente tinha ciência, na época da aquisição, da ação em curso que levaria aquele ao estado de insolvência." (OLIVEIRA, José Sebastião de. Fraude à execução. 2. ed. São Paulo: Saraiva, 1988. p. 74) e, mais atualmente, Eduardo Henrique de Oliveira Yoshikawa: "não se exige, para a aplicação do instituto, a citação do executado, nem se cogita da boa-fé do adquirente do bem alienado, quer se cuide de aquisição realizada diretamente do executado, quer se cuide de aquisição de terceiro, após alienações sucessivas." (YOSHIKAWA, Eduardo Henrique de Oliveira. Do caráter objetivo da fraude à execução e suas consequências (artigo 593, II, do CPC). Revista Dialética de Direito Processual, n. 25,p. 45, abr. 2005).

${ }^{2}$ Sobre a terminologia usada nesta tese, inclusive o sentido de "devedor" e "terceiro imediato e mediato" aqui mencionados, cf. item 2.1, infra.

${ }^{3}$ Nesse sentido, Gelson Amaro de Souza: "para a configuração da fraude de execução, necessária se faz, a presença da má-fé, tanto do devedor que vende ou onera a coisa, bem como do terceiro adquirente." (SOUZA, Gelson Amaro de. Fraude de execução e o direito de defesa do adquirente. São Paulo: Juarez de Oliveira, 2002. p. 90); Araken de Assis: "é a partir da data em que ocorreu a citação do réu, portanto, que se
} 
Entre os dois extremos, há várias posições intermediárias, como (i) a que exige apenas a má-fé do devedor, decorrente de sua citação, não a do terceiro; ${ }^{4}$ (ii) a que simplesmente sustenta que apenas a má-fé do terceiro seria relevante para a configuração da fraude de execução, não a do devedor; ${ }^{5}$ (iii) a que vislumbra a existência de presunções

passará a cogitar da fraude contra a execução" e, mais adiante, diz que, ausente o registro público da citação ou da penhora, "incumbe ao exequente provar, por outros meios, que o adquirente conhecia a litispendência." (ASSIS, Araken de. Comentários ao Código de Processo Civil. 2. ed. Rio de Janeiro: Forense, 2003. p. 246 e 252); Cledi de Fátima Manica Moscon: "é de se concluir pela necessidade da citação o demandado como marco temporal inicial a configurar, em fraude de execução, os atos de disposição praticados pelo devedor. Entretanto o critério não deve ser rígido, comportanto prova inequívoca da ciência do réu da demanda em curso, mesmo antes de citado (...) a scientia fraudis há de ser exigida para que o terceiro adquirente sofra os efeitos da constrição dos bens adquiridos" (MOSCON, Cledi de Fátima Manica. Fraude de execução judicial. São Paulo: LTr, 2007. p. 104 e 118); Dinamarco "reputa-se momento inicial do processo, para o fim de caracterização da fraude executiva, aquele em que é feita a citação do demandado e não aquele em que o processo tem início (propositura da demanda); só então ele fica ciente da demanda proposta, não sendo razoável nem legítimo afirmar uma fraude da parte de quem ainda não tenha conhecimento da litispendência instaurada (...). Mas essa razão cessa quando por algum modo o demandado já tiver conhecimento da pendência do processo, antes de ser citado; essa é uma questão de fato a ser apreciada caso a caso, sendo legítimo considerar até mais maliciosa a conduta daquele que se furta à citação com o objetivo de desfazer-se de bens ou onerá-los antes que esta se consuma. (...) Em princípio, só podem considerar-se ineficazes os atos de disposição ou oneração de bens em fraude de execução se o adquirente tiver conhecimento da existência do processo ou houver razões para que não pudesse ignorá-la. Como é ele quem irá suportar diretamente os inconvenientes dessa ineficácia, não se admite que esta se imponha quando estiver absolutamente inocente, não sabendo e não tendo razoavelmente como saber da litispendência." (“As Fraudes do Devedor”, Instituições de direito processual civil. 3. ed. São Paulo: Malheiros, 2009. v. 4, p. 443-444); Paulo Henrique dos Santos Lucon: "antes da penhora, os requisitos caracterizadores da fraude de execução podem ser assim elencados: a) ato jurídico que importe a alienação ou oneração de bens; b) capaz de reduzir o devedor à insolvência; c) após a sua citação em processo cognitivo ou executivo ou, ainda, o seu conhecimento inequívoco da existência da demanda por qualquer meio possível de ser provado judicialmente (p. ex. notificação) (...)A falta de registro não impede a alegação de fraude de execução, mas tem conseqüência direta sobre o ônus da prova. Isso significa, em síntese, que o exeqüente, sem o registro da penhora, tem o encargo de provar a má-fé do adquirente como imperativo de seu interesse. Ou seja, competirá ao exeqüente provar que o adquirente tinha conhecimento de que estava sendo movida em face do alienante demanda capaz de provocar um substancial desequilíbrio patrimonial de tal modo que ficaria insolvente." LUCON, Paulo Henrique dos Santos. Fraude à execução, responsabilidade processual civil e registro da penhora. Revista Síntese de Direito Civil e Processual Civil, Porto Alegre, v. 1, n. 5, p. 132 e 139, maio/jun. 2000). É também esse o entendimento dominante na jurisprudência do Superior Tribunal de Justiça, conforme se verifica, por todos, no acórdão de sua Corte Especial no EREsp. 259.890/SP, rel. Min. José Delgado, j. 02.06.04: "não é possível a declaração de fraude de execução sem a existência de demanda anterior com citação válida" e na súmula 375, de março de 2009 : "o reconhecimento da fraude à execução depende do registro da penhora do bem alienado ou da prova de má-fé do terceiro adquirente."

${ }^{4}$ Cf. MOURA, Mário Aguiar. Fraude de execução pela insolvência do devedor. Revista dos Tribunais, São Paulo, n. 509, p. 301-302, mar. 1978; "Para a caracterização da fraude de execução prevista no inciso II do Art. 593 do CPC é necessário apenas: alienação ou oneração de bens na pendência de demanda (de conhecimento ou executiva), com citação válida, capaz de reduzir o devedor à insolvência (...) Em momento algum a lei exige a ciência do adquirente como elemento da fraude de execução" (STJ, $3^{\mathrm{a}} \mathrm{T}$., RMS 24.293/RJ, rel. Min. Humberto Gomes de Barros, j. 23.10.07).

${ }^{5}$ Cf., entre outros, Frederico Fontoura da Silva Cais: "não se mostra lícito diferir tal marco [inicial da fraude de execução] para o momento em que for efetivada a citação do réu. (...) o que mais importa para fim de verificação da fraude é a ciência pelo terceiro adquirente - e não pelo réu - da existência do processo em curso" (CAIS, Frederico Fontoura da Silva. Fraude de execução. São Paulo: Saraiva, 2005. p. 132 e 135 sem colchetes no original). 
legais relativas no artigo 593 do CPC, ora em favor do credor, ora em favor do terceiro; ${ }^{6}$ ou, ainda, (iv) a que entende que o elemento subjetivo somente seria relevante no caso específico de alienação ou oneração de bem penhorado. ${ }^{7}$

A questão não é de menor importância e não pode permanecer ao sabor de tamanha diversidade de entendimentos. Sobre ela equilibram-se - em difícil, porém necessária convivência - nada menos que os princípios da responsabilidade patrimonial que, em substituição à responsabilidade pessoal do devedor, certamente é um dos maiores legados do direito romano, e do devido processo legal, advindo da Magna Carta de 1215, ambos erigidos em nosso ordenamento ao status de garantias constitucionais. ${ }^{8}$

O instituto da fraude de execução busca, assim, conciliar dois objetivos: de um lado, evitar que a atividade jurisdicional se frustre porque os bens que estariam sujeitos a ela foram transferidos para o patrimônio de terceiro; e, de outro lado, definir claramente em que situações os bens permanecerão sujeitos à atividade jurisdicional ainda que estejam em patrimônio de terceiro. Esse sistema se completa, ainda, pela existência à disposição do terceiro de um meio processual para que esse possa alegar e provar que a

${ }^{6}$ Cf. José Eli Salamacha que, baseando-se no princípio da proporcionalidade, sustenta que "haverá presunção relativa em benefício do credor (autor), podendo ser declarada de imediato a fraude à execução, se a demanda tramitar na mesma comarca em que se localizar o imóvel litigioso ou no domicílio do alienante, cabendo ao adquirente provar o contrário por meio dos embargos de terceiro. (...) Se, no entanto, a demanda não correr na mesma comarca em que se localizar o imóvel objeto da alienação ou oneração, ou no domicílio do alienante, entendemos que a presunção relativa deva correr em favor do adquirente" (SALAMACHA, José Eli. Fraude de execução: direitos do credor e do adquirente de boa-fé. São Paulo: Ed. Revista dos Tribunais, 2005. p. 163-164) e mesmo acórdãos do Superior Tribunal de Justiça prolatados pouco antes da súmula 375: "o inciso II, do art. 593, do CPC, estabelece uma presunção relativa da fraude, que beneficia o autor ou exeqüente, razão pela qual é da parte contrária o ônus da prova da inocorrência dos pressupostos da fraude de execução" (STJ, 3 ${ }^{a}$ T., REsp 618.625/SC, rel. Min. Nancy Andrighi, j. 19.02.08).

${ }^{7}$ Nesse sentido, cf. Amílcar de Castro: "faz-se no registro de imóveis a inscrição das penhoras, arrestos e seqüestros de imóveis (...) não sendo feita a inscrição, o exeqüente deve provar as condições legais de existência de fraude de execução. Vale dizer: a inscrição só tem efeito de publicidade, e, vale como prova presumida, irrefragável, de conhecimento das condições da fraude por parte de terceiros." (CASTRO, Amílcar de. Comentários ao Código de Processo Civil. São Paulo: Ed. Revista dos Tribunais, 1974. v. 8, p. 86-87). Tal autor é o precursor dessa interpretação, fazendo-a já na vigência do Código de Processo Civil de 1939, como será visto no item 4.3, infra. Atualmente, dela também partilha Luiz Fux: "a lei exige o registro da penhora, quando imóvel o bem constrito. A novel exigência visa à proteção do terceiro de boafé, e não é ato essencial à formalização da constrição judicial; por isso o registro não cria prioridade na fase de praceamento. Entretanto, a moderna exigência do registro, altera a tradicional concepção da fraude de execução; razão pela qual somente a alienação posterior ao registro é que caracteriza a figura em exame. Trata-se de uma exceção criada pela própria lei, sem que se possa argumentar que a execução em si seja uma demanda capaz de reduzir o devedor à insolvência e, por isso, a hipótese estaria enquadrada no inciso II do art. 593 do CPC. A referida exegese esbarraria na ratio legis que exsurgiu com o nítido objetivo de proteger os terceiros adquirentes." (FUX, Luiz. O novo processo de execução: o cumprimento da sentença e a execução extrajudicial. Rio de Janeiro: Forense, 2008. p. 100).

${ }^{8}$ Art. $5^{\circ}$, LIV - ninguém será privado da liberdade ou de seus bens sem o devido processo legal.

Art. 5, LXVII - não haverá prisão civil por dívida, salvo a do responsável pelo inadimplemento voluntário e inescusável de obrigação alimentícia e a do depositário infiel; 
situação em que o bem foi transferido ao seu patrimônio não se configurava como alguma daquelas definidas como fraude de execução. ${ }^{9}$

É nesse difícil equilíbrio que se insere o tema objeto desta tese. Será apenas definindo-se claramente em que consiste e que relevância tem o elemento subjetivo para a configuração das diversas hipóteses de fraude de execução, que tanto o credor quanto o terceiro saberão exatamente os ônus de que precisam se desincumbir para evitarem riscos a seus respectivos direitos.

A permanecência da grande diversidade de entendimentos descrita acima leva, inexoravelmente, ao indesejável casuísmo, que somente contribui para aumentar o grau de desconfiança na atuação do Poder Judiciário ${ }^{10}$ e, portanto, deve ser combatido.

Não nos parece útil, aqui, explorar cada um dos entendimentos existentes, verificando qual deles traria a resposta mais satisfatória à questão formulada acima. Até mesmo porque, segundo nossa análise, nenhum abarca todos os aspectos da solução que reputamos correta.

\footnotetext{
${ }^{9} \mathrm{O}$ meio pelo qual, atualmente, o terceiro pode impugnar a configuração da fraude de execução no sistema aqui descrito são os embargos de terceiro (arts. 1.046 e ss. do CPC). Há, contudo, respeitável corrente doutrinária que questiona a constitucionalidade desse sistema, seja pela limitação do objeto dos embargos de terceiro, seja pelo diferimento do exercício do devido processo legal nesse caso. É o que sustenta Sérgio Coelho Junior com os seguintes fundamentos "os embargos de terceiro, embora ostentem a natureza de ação cognitiva constitutiva, não se oferecem como sede própria ao reconhecimento da fraude de execução, porque neles a cognição é sumária, tanto em sentido vertical, quanto em sentido horizontal. Ainda que se amplie e aprofunde a cognição nos embargos, subsistirá a incompatibilidade dessa via para a pesquisa da fraude - seja de execução, seja contra credores - pois ela somente se abre quando já consumada ou determinada a constrição do bem de terceiro. O contraditório tem de ser efetivo, ou seja, às partes (e a todo aquele que tiver uma pretensão de direito material a proteger em juízo) deve-se franquear a oportunidade de previamente influenciar a decisão que afetará seus direitos." (COELHO JUNIOR, Sérgio. Fraude de execução e garantias fundamentais do processo. Rio de Janeiro: Lumen Juris, 2006. p. 157). Não nos parece haver aqui qualquer inconstitucionalidade. Embora concordemos que a ampliação do objeto de discussão nos embargos de terceiro seja de todo vantajosa e, à semelhança de José Rogério Cruz e Tucci (Limites subjetivos da eficácia da sentença e da coisa julgada civil. São Paulo: Ed. Revista dos Tribunais, 2006. p. 350), já a tenhamos sugerido em trabalho anterior (Embargos de terceiro: legitimidade passiva. São Paulo: Atlas, 2006. p. 105-107), os limites atuais dessa ação não comprometem o objetivo de discutir a ocorrência ou não de fraude de execução. Também sua posterioridade em relação à constrição não ameça a constitucionalidade do instituto. Nesse ponto, a situação assemelha-se à dos embargos do executado tal como vigiam à época em que escreveu o autor. O executado somente poderia embargar após ter seus bens constritos. E, mesmo considerando a disciplina atual da Lei n. ${ }^{\circ}$ 11.382/2006, os embargos de terceiro ainda apresentam mais vantagens em relação aos embargos do devedor, pois diferentemente desses, aqueles sustam de imediato os atos executivos (art. 1.052, CPC) e dispõem de liminar possessória, que mantém ou reintegra o embargante na posse do bem (art. 1.051, CPC).

${ }^{10}$ Segundo pesquisa denominada "Barômetro de Confiança nas Instituições Brasileiras", apresentada pela Associação dos Magistrados Brasileiros em junho de 2008 e divulgada pelo Conselho Nacional de Justiça, apenas 56\% dos entrevistados afirmaram confiar no Poder Judiciário (cf. <www.cnj.jus.br>).
} 
Ao contrário, preferimos confrontar a hipótese por nós apresentada nesta tese com o entendimento que atualmente tem se apresentado como dominante, enfocando seus pontos de divergência e as razões de nossa discordância.

Assim, como já exposto, tem predominado o entendimento de que, para a configuração das diversas hipóteses da fraude de execução, é necessária a má-fé tanto do devedor quanto do terceiro - seja ele imediato ou mediato. Além disso, tem-se considerado tal má-fé como decorrente da ciência da pendência da ação, o que, do lado do devedor se dá por meio de sua citação, admitindo-se ainda outra prova, a cargo do credor; do lado do terceiro, dependeria da inscrição de algum ato que dê notícia da pendência da ação em registro público, ou outra prova, igualmente a cargo do credor.

A hipótese que se pretende demonstrar nesta tese é que, ao contrário do que sustenta o entendimento dominante, o elemento subjetivo não é relevante para a configuração de todas as hipóteses de fraude de execução, sendo irrelevante (i) nos casos do artigo 593, I, do CPC - pendência de ação fundada em direito real -; (ii) quando, nos casos do artigo 593, II, do CPC - pendência de ação que possa reduzir o devedor à insolvência -, a notícia da pendência da ação constar de registro público; e (iii) nos casos do artigo 593, III, do CPC, cumulado com o artigo 129 da Lei n. ${ }^{\circ}$ 11.101/2005 - período suspeito da falência. Somente nos outros casos o elemento subjetivo seria relevante para a configuração da fraude de execução.

Mais ainda, procurar-se-á demonstrar que a feição do elemento subjetivo relevante para a configuração da fraude de execução não é a má-fé tanto do devedor quanto do terceiro, decorrente de sua efetiva ciência da pendência da ação, como o apresenta o entendimento dominante, e sim apenas a má-fé do terceiro, sendo que essa decorre não só de sua ciência efetiva, como também da existência de razão para que esse saiba da ação pendente e de sua possível consequência para o patrimônio do devedor. Além disso, sustentar-se-á, ainda, que não há base legal para se atribuir exclusivamente ao credor o ônus de prova quanto ao elemento subjetivo para a configuração da fraude de execução.

Por fim, demonstrar-se-á que a hipótese acima enunciada não apenas apresenta-se mais fiel à origem histórica da fraude de execução, como também decorre de interpretação mais adequada aos vários dispositivos legais que se relacionam com a matéria e com a visão da ciência processual sobre a responsabilidade patrimonial. 


\section{2- Organização e desenvolvimento do trabalho}

Para atingir o objetivo proposto, a primeira dificuldade a ser vencida é a definição dos contornos da própria fraude de execução. Dado o objeto específico desta tese, evitamos realizar, aqui, abordagem ampla, abarcando todos os aspectos do instituto, até porque já existem diversos trabalhos na doutrina processual brasileira nesse sentido. ${ }^{11}$ Ao contrário, na primeira parte do trabalho, limitamo-nos a esclarecer questões relacionadas à terminologia utilizada nesta tese, a firmar algumas premissas conceituais e a identificar as hipóteses de fraude de execução atualmente previstas na legislação.

Em seguida, definimos, à luz da doutrina e da jurisprudência, a feição e a relevância que o entendimento dominante atribui ao elemento subjetivo para a configuração da fraude de execução.

Pretendendo por à prova o entendimento dominante frente aos dispositivos que disciplinam o instituto no Código de Processo Civil, verificamos que esses não fornecem orientação segura, uma vez que, após as sucessivas reformas processuais, as normas antigas e novas apontam para sentidos diferentes, ${ }^{12}$ dando ensejo às diversas interpretações acima expostas. Valendo-nos, portanto, do ensinamento de CARNELUTTI de que "per conoscere il diritto vigente occore studiare anche il diritto passato, come per conoscere il diritto di un paese ocorre studiare anche quello di un'altro," ${ }^{13}$ para tal tarefa, procuramos, então, buscar elementos de apoio no direito pretérito e no direito estrangeiro.

No entanto, uma das análises logo se viu frustrada pelo fato de a fraude de execução ser instituto sem similar nos ordenamentos estrangeiros. ${ }^{14}$ De fato, apenas

\footnotetext{
${ }^{11}$ Cf. SOUZA, Gelson Amaro de. Fraude de execução e o direito de defesa do adquirente, cit.; CAIS, Frederico Fontoura da Silva. Fraude de execução, cit.; SALAMACHA, José Eli. Fraude de execução: direitos do credor e do adquirente de boa-fé, cit.; COELHO JUNIOR, Sérgio. Fraude de execução e garantias fundamentais do processo, cit.; MOSCON, Cledi de Fátima Manica. Fraude de execução judicial, cit.; PEÑA, Ricardo Chemale Selistre. Fraude à execução. Porto Alegre: Livraria do Advogado, 2009, apenas para citar as monografias mais recentes.

${ }^{12}$ Nos artigos 592, V, e 593, existentes no sistema original do Código de Processo Civil, não há qualquer menção ao elemento subjetivo, seja do devedor, seja de terceiro, para a configuração da fraude de execução. No entanto, as alterações promovidas pelas Leis n. ${ }^{\text {os }} 8.953$, de 14 de dezembro de 1994, 10.444, de 7 de maio de 2002, e 11.382, de 6 de dezembro de 2006, introduziram as normas do $\S 4^{\circ}$ do artigo 659 e do artigo 615-A, que versam sobre a presunção absoluta de ciência do terceiro quanto à existência da ação pendente, caso essa informação conste de registros públicos, criando aparente contradição no Código de Processo Civil.

${ }^{13}$ CARNELUTTI, Francesco. Sistema di diritto processuale civile. Padova: Cedam, 1936 v. 1, p. 2.

${ }^{14} \mathrm{~A}$ exclusividade brasileira da fraude de execução é pacífica na doutrina nacional. Cf., entre outros, LIMA, Alcides de Mendonça. Comentários ao Código de Processo Civil. 3. ed. Rio de Janeiro: Forense, 1979. v. 6, t. 2, p. 554; LIEBMAN, Enrico Tullio. Processo de execução, cit., p. 127; TEIXEIRA, Sálvio de
} 
para tomar por base os ordenamentos italiano e português, normalmente os mais utilizados como paradigma do direito processual brasileiro, sobretudo em matéria de execução, verificamos que, regulamentando situações assemelhadas àquelas em que incide a fraude de execução, existem disposições referentes à alienação de bem litigioso ${ }^{15}$ e alienação de bem penhorado, ${ }^{16}$ sendo as demais resolvidas similarmente à nossa fraude contra credores, com a necessidade de ajuizamento de ação autônoma semelhante à ação pauliana. ${ }^{17}$

Figueiredo. Fraude de execução. Revista dos Tribunais, São Paulo, n. 609, p. 8, jul. 1986; OLIVEIRA, José Sebastião de. Fraude à execução, cit., p. 53; CAIS, Frederico Fontoura da Silva. Fraude de execução, cit., p. 111-112; SALAMACHA, José Eli. A fraude de execução no direito comparado. Revista de Processo, São Paulo, v. 31, n. 131, jan. 2006 p. 110; DINAMARCO, Cândido Rangel. As fraudes do devedor. In: . Instituições de direito processual civil. 3. ed. São Paulo: Malheiros, 2009. v. 4, p. 441.

${ }^{15}$ Cf. o artigo $271^{\circ}$ do Código de Processo Civil português:

"Artigo $271^{\circ}$ (Legitimidade do transmitente - Substituição deste pelo adquirente)

1. No caso de transmissão, por acto entre vivos, da coisa ou direito litigioso, o transmitente continua a ter legitimidade para a causa, enquanto o adquirente não for, por meio de habilitação, admitido a substituí-lo.

2. A substituição é admitida quando a parte contrária esteja de acordo. Na falta de acordo, só deve recusar-se a substituição quando se entenda que a transmissão foi efectuada para tornar mais difícil, no processo, a posição da parte contrária.

3. A sentença produz efeitos em relação ao adquirente, ainda que este não intervenha no processo, excepto no caso de a acção estar sujeita a registo e o adquirente registar a transmissão antes de feito o registo da acção."

E o artigo 111 do Código de Processo Civil italiano:

"Art. 111 (Successione a titolo particolare nel diritto controverso)

Se nel corso del processo si trasferisce il diritto controverso per atto tra vivi a titolo particolare, il processo prosegue tra le parti originarie.

Se il trasferimento a titolo particolare avviene a causa di morte, il processo é proseguito dal successore universale o in suo confronto.

In ogni caso il successore a titolo particolare puó intervenire o essere chiamato nel processo e, se le altre parti vi consentono, l'alienante o il successore universale puó esserne estromesso.

La sentenza pronunciata contro questi ultimi spiega sempre i suoi effetti anche contro il successore a titolo particolare ed é impugnabile anche da lui, salve le norme sull'acquisto in buona fede dei mobili e sulla trascrizione."

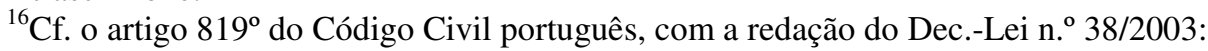

"Artigo $819^{\circ}$ (Disposição ou oneração dos bens penhorados)

Sem prejuízo das regras do registro, são inoponíveis em relação à execução os actos de disposição, oneração ou arrendamento dos bens penhorados."

E o artigo 2.913 do Código Civil italiano:

"Art. 2.913. (Inefficacia delle alienazioni del bene pignorato)

Non hanno effetto in pregiudizio del creditore pignorante e dei creditori che intervengono nell'esecuzione (Cod. Proc. Civ. 498 e seguenti) gli atti di alienazione dei beni sottoposti a pignoramento, salvi gli effetti del possesso di buona fede per i mobili (1.153 e seguenti) non iscritti in pubblici registri."

${ }^{17} \mathrm{Cf}$. artigo $610^{\circ}$ do Código Civil português:

"Subsecção III - Impugnação pauliana - Artigo $610^{\circ}$ (Requisitos gerais)

Os actos que envolvam diminuição da garantia patrimonial do crédito e não sejam de natureza pessoal podem ser impugnados pelo credor, se concorrerem as circunstâncias seguintes:

a) Ser o crédito anterior ao acto ou, sendo posterior, ter sido o acto realizado dolosamente com o fim de impedir a satisfação do direito do futuro credor;

b) Resultar do acto a imposibilidade, para o credor, de obter a satisfação integral do seu crédito, ou agravamento dessa impossibilidade."

E o artigo 2.901 do Código Civil italiano:

"Sezione II - Dell'azione revocatoria - Art. 2.901 (Condizioni)

Il creditore, anche se il credito è soggetto a condizione o a termine, può domandare che siano dichiarati inefficaci nei suoi confronti gli atti di disposizione del patrimonio coi quali il debitore rechi pregiudizio alle sue ragioni quando concorrono le seguenti condizioni: 
Justifica-se, assim, nossa opção em não dedicarmos, nesta tese, um capítulo específico à análise detalhada de institutos de direito estrangeiro. No entanto, sempre que se mostrar útil, utilizaremos o confronto com tais institutos para elucidar algum ponto específico. De momento, partindo desse breve cotejo com os ordenamentos italiano e português, cabe apenas registrar que nosso regramento sobre a matéria mostra-se mais vantajoso, uma vez que o direito de executar bens alienados em fraude de execução proporciona maior garantia à eficácia da atividade executiva do que os institutos presentes naqueles países. Afirma-se isso, especialmente em relação ao caso do artigo 593, II, do CPC, pois, para a legislação italiana e portuguesa, haja ou não processo em curso quando alienado o bem, deve ser ajuizada ação autônoma para ser reconhecida a fraude.

Diante do pouco proveito que traria a análise do direito estrangeiro para a elucidação do nosso tema específico, dedicamo-nos à pesquisa da parte histórica e, tendo em conta o ensinamento de CARLOS MAXIMILIANO de que "mais importante do que a história geral do Direito é, para o hermeneuta, a especial de um instituto e, em proporção maior, a do dispositivo ou norma submetida à exegese," ${ }^{18}$ concentramos nossos esforços em traçar, passo a passo, a origem e a evolução da norma que hoje se encontra no artigo 593 do CPC, identificando quais as hipóteses em que o elemento subjetivo se fazia relevante na história da fraude de execução e qual a feição que era atribuída e esse elemento subjetivo.

Identificadas a feição e a relevância do elemento subjetivo para a fraude de execução extraídas na origem do instituto, faz-se o seu confronto com o entendimento dominante, confirmando a tese proposta tanto à luz da legislação em vigor, quanto em relação à moderna concepção do instituto da responsabilidade patrimonial.

Feito isso, prossegue-se com a sugestão de metodologia para análise dos casos de fraude de execução com base na hipótese aqui proposta.

1) che il debitore conoscesse il pregiudizio che l'atto arrecava alle ragioni del creditore o, trattandosi di atto anteriore al sorgere del credito, l'atto fosse dolosamente preordinato al fine di pregiudicarne il soddisfacimento;

2) che, inoltre, trattandosi di atto a titolo oneroso, il terzo fosse consapevole del pregiudizio, e, nel caso di atto anteriore al sorgere del credito, fosse partecipe della dolosa preordinazione.

Agli effetti della presente norma, le prestazioni di garanzia, anche per debiti altrui, sono considerate atti a titolo oneroso, quando sono contestuali al credito garantito.

Non è soggetto a revoca l'adempimento di un debito scaduto.

L'inefficacia dell'atto non pregiudica i diritti acquistati a titolo oneroso dai terzi di buona fede, salvi gli effetti della trascrizione della domanda di revocazione." 
Finalmente, conclui-se o trabalho com a verificação das propostas dos Projetos de Lei n. ${ }^{\text {os }} 3.057 / 2000$ e 5.951/2009 para a disciplina futura da fraude de execução, apresentando sugestão alternativa, com base na análise empreendida nesta tese.

${ }^{18}$ MAXIMILIANO, Carlos. Hermenêutica e aplicação do direito. 19. ed. Rio de Janeiro: Forense, 2001. p. 113. 


\section{2- FRAUDE DE EXECUÇÃO: TERMINOLOGIA, PREMISSAS CONCEITUAIS E HIPÓTESES LEGAIS}

\section{1- Considerações de caráter terminológico}

O termo fraude de execução foi usado pela primeira vez no Direito Processual brasileiro pelo Regulamento n. ${ }^{\mathrm{o}} 737$, de $1850,{ }^{19}$ sendo repetido sem alteração por toda a legislação processual brasileira subsequente, ${ }^{20}$ embora nem sempre para designar as mesmas circunstâncias. Desde esse primeiro momento, o termo foi escolhido para expressar a circunstância excepcional em que determinado ato jurídico válido e, em princípio, totalmente eficaz, tornava-se inoponível em relação ao processo cuja atividade jurisdicional executiva seria frustrada se aquele ato produzisse todos os seus efeitos.

A escolha do termo fraude para designar o instituto certamente contribui para a dificuldade de identificação da relevância que o legislador pretendeu atribuir ao elemento subjetivo para sua configuração, dado o duplo sentido que possui.

De um lado, segundo a clássica lição de Alvino LiMA, “a fraude envolve a má-fé, porque é inconcebível, normalmente, que o frustrador da lei, procurando obter um resultado proibido pela norma jurídica; procurando conscientemente subtrair-se dos efeitos de um dispositivo legal imperativo, não esteja agindo de má-fé.” De fato, já no início de sua obra, esse mesmo autor esclarece que "a má-fé é a expressão genérica que abrange todas as modalidades dos que agem contrariando aquele princípio de boa-fé a que nos referimos; é o gênero dos quais o dolo, a fraude e a simulação fraudulenta constituem feições especiais e que se distinguem, não só na sua própria estrutura, assim como nos processos postos em jogo para a sua realização e nos seus resultados.",21

\footnotetext{
${ }^{19}$ Previa o artigo $492^{\circ}, \S 6^{\circ}$, do referido regulamento que a execução poderia se fazer contra "o comprador ou possuidor de bens hypothecados, segurados, ou alienados em fraude de execução...".

${ }^{20}$ Atualmente, o Código de Processo Civil prevê em seu artigo 592, V, que "ficam sujeitos à execução os bens: (...) V - alienados ou gravados com ônus real em fraude de execução."

${ }^{21}$ LIMA, Alvino. A fraude no direito civil. São Paulo: Saraiva, 1965. p. 51 e 25, respectivamente. Também considerando que a fraude se encerra no gênero da má-fé, Flávio Luiz Yarshell afirma que a simulação e a fraude "integram o gênero de 'atos de má-fé', constituindo expediente malicioso empregado para prejudicar terceiros que nele não intervêm." (YARSHELL, Flávio Luiz. Simulação e processo de execução. In: SHIMURA, Sérgio; WAMBIER, Teresa Arruda Alvim (Coords.). Processo de execução e assuntos afins. São Paulo: Ed. Revista dos Tribunais, 1998. p. 230) e CAHALI, Yussef Said. Fraudes contra credores. 3. ed. São Paulo: Ed. Revista dos Tribunais, 2002. p. 51-52.
} 
De outro lado, contudo, entende PonTES DE MiRAnda que "fraudar é apenas violar indiretamente. Qualquer elemento subjetivo que se intrometa provém da confusão com outros elementos do suporte fático das regras jurídicas sobre fraude; portanto, de elementos que não são a fraus. Quem frauda frustra. O étimo é o mesmo. Quem frauda viola, frustrando. Violar, frustrando, é violar indiretamente. Se o sistema jurídico exige algum elemento subjetivo, esse elemento é à parte."22

Como se percebe, a adoção de um ou do outro sentido aproxima ou afasta o elemento subjetivo do foco da análise da fraude de execução.

Ainda quanto à expressão fraude de execução, muitos autores substituem a preposição "de", usada pelo legislador, por outras como "a", "contra" ou "em", sendo comuns as expressões "fraude à execução", "fraude contra a execução" e "fraude na execução". Excetuada essa última, que traduz a ideia de que o ato foi praticado durante a fase ou o processo de execução, ${ }^{23}$ as outras duas também exprimem bem o instituto.

Como se sabe, a preposição "a" indica objetivo ou movimento de aproximação. ${ }^{24}$ Assim, "fraude à execução" exprime a ideia do objetivo almejado com o ato fraudulento: frustrar a atividade executiva. Já a preposição "contra" traz a ideia de em frente de ou em oposição a. ${ }^{25}$ Dessa forma, a expressão "fraude contra a execução" menos comum que as outras - contém o sentido de que a fraude se oporia à execução.

Melhor, contudo, é ater-se à expressão fraude de execução. Não apenas por ser a terminologia adotada pelo legislador desde o surgimento do instituto, mas também porque efetivamente exprime melhor o sentido almejado pelo legislador. A preposição "de" indica circunstância ou matéria, ${ }^{26}$ de modo que fraude de execução caracteriza o tipo de fraude, delimitando uma circunstância específica e separando-a das

\footnotetext{
${ }^{22}$ MIRANDA, Francisco Cavalcanti Pontes de. Tratado de direito privado. Rio de Janeiro: Borsoi, 1954. t. 4, p. 415.

${ }^{23} \mathrm{O}$ que retringe o sentido, dado que as situações descritas no art. 593, CPC podem ocorrer ainda na fase de conhecimento. Reforça esse entendimento Sérgio Coelho Junior ao explicar que "é do locus do seu reconhecimento - e não de sua ocorrência - que deriva a denominação legal." (COELHO JUNIOR, Sérgio. Fraude de execução e garantias fundamentais do processo, cit., p. 90).

${ }^{24}$ Como nas expressões "tiro ao alvo", "viagem à Alemanha" etc. (BUENO, Francisco da Silvera. Grande dicionário etimológico-prosódico da língua portuguesa. 2. tir. São Paulo: Saraiva, 1968. v. 1, p. 1).

${ }^{25}$ É o sentido que se observa em "colocou-se contra a luz", "nadar contra a corrente" etc. (BUENO, Francisco da Silvera. Grande dicionário etimológico-prosódico da língua portuguesa, cit., v. 2, p. 806).

${ }^{26}$ Como nas expresões "concerto de câmara", "jogo de cartas" etc. (Cf. BUENO, Francisco da Silvera. Grande dicionário etimológico-prosódico da língua portuguesa, cit., v. 2, p. 877).
} 
demais. Não designa qualquer fraude que tenha por objetivo frustrar a atividade jurisdicional executiva, mas apenas aquelas situações previstas taxativamente pela lei. ${ }^{27}$

Como será visto no capítulo 4 desta tese, fraude de execução foi um termo cunhado para abarcar circunstâncias diversas, inserindo-as sob uma denominação comum entre as outras hipóteses de responsabilidade executória secundária. ${ }^{28}$

Em relação às pessoas envolvidas nas diversas situações de fraude de execução, procurando evitar distinções repetitivas, utilizaremos o termo "credor" para designar, indistintamente, tanto o exequente, quanto o autor da ação condenatória ou da ação fundada em direito real. Da mesma forma, usaremos "devedor" para designar tanto o executado, quando o réu nessas ações. Faz-se essa opção consciente da diferença de sentido que as expressões têm no direito processual e material, ${ }^{29}$ mas seguindo a terminologia adotada pelo próprio legislador no artigo 593, II, do CPC, que é também a utilizada pela maioria dos acórdãos e da doutrina sobre o tema, como será visto ao longo desta tese.

\footnotetext{
${ }^{27}$ Em sentido semelhante, cf. Frederico Fontoura da Silva Cais (Fraude de execução, cit., p. 99) e José Eli Salamacha (Fraude de execução: direitos do credor e do adquirente de boa-fé, cit., p. 137), embora esse último tenha preferido utilizar-se da expressão "fraude à execução".

${ }^{28}$ Desde o Regulamento 737, de 1850, até o Código de Processo Civil atual, a fraude de execução encontra-se disciplinada normalmente em duas normas interligadas. Na primeira delas, o legislador prevê mais uma hipótese de responsabilidade executória secundária: "bens alienados em fraude de execução" (cf. art. 492º $\S 6^{\circ}$, do Regulamento 737 e art. 592, V, CPC). Na segunda norma, o legislador especifica quais são as circunstâncias em que a alienação será considerada em "fraude de execução" (cf. art. $494^{\circ}, \S \S 1^{\circ}$ a $3^{\circ}$, do Regulamento 737 e, atualmente, art. 593, I a III, do CPC). Na prática, equivaleria a incluir na primeira norma não uma, mas tantas mais hipóteses de responsabilidade executória secundária quantas forem as circunstâncias em que o legislador considera que a alienação ocorre em "fraude de execução". Assim, por exemplo, o artigo 592 do CPC seria redigido dessa forma:
}

Art. 592. Ficam sujeitos à execução os bens:

I- do sucessor a título singular, tratando-se de execução fundada em direito real ou obrigação reipersecutória;

II- do sócio, nos termos da lei;

III- do devedor, quando em poder de terceiros;

$I V$ - do cônjuge, nos casos em que os seus bens próprios, reservados ou de sua meação respondem pela divida;

$V$ - alienados ou onerados quando sobre eles pender ação fundada em direito real; (cf. art. 593, I)

VI- alienados ou onerados quando, no momento da alienação ou oneração, corria contra o devedor demanda capaz de reduzi-lo à insolvência; (cf. art. 593, II)

VII- do terceiro que teve seu débito quitado pelo devedor após penhora até o valor desse débito (cf. art. 593, III, c/c art. 672, $\$ 3^{\circ}$, do $\left.C P C\right)$;

VIII- alienados ou onerados no período suspeito da falência (cf. art. 593, III, c/c art. 129 da Lei n. ${ }^{o}$ 11.101/05);

IX-alienados ou onerados após a inscrição de crédito tributário como dívida ativa (cf. art. 593, III, c/c art. 185 do CTN).

${ }^{29}$ Sobre o tema, cf., por todos, SHIMURA, Sérgio. Título executivo. 2. ed. São Paulo: Método, 2005. p. 79. 
Ainda em relação às pessoas envolvidas, utilizaremos a expressão "terceiro" também de forma ampla, significando tanto o adquirente do bem alienado em fraude de execução, quanto o beneficiário do ônus real instituído nessas circunstâncias. Apenas uma diferenciação se faz necessária nesse ponto: trata-se da menção que fazemos a "terceiros mediatos" e "terceiros imediatos", significando estes os que adquiriram os bens diretamente do devedor e aqueles os que já os adquiram de outro terceiro. ${ }^{30}$

Novamente com o objetivo de evitar distinções desnecessárias ao longo desta tese, a menção a "alienação ou oneração" será substituída simplesmente pela expressão "alienação", englobando esta também a "oneração", com as observações feitas no item 7.2, infra, sobre a forma diversa pela qual os atos de oneração frustram a atividade executiva. A mesma observação vale em relação a "alienados e onerados" que passam a ser mencionados apenas como "alienados" e assim por diante.

Por fim, utiliza-se aqui também indistintamente a expressão "execução" para designar não só os casos de execução propriamente dita, mas também os de cumprimento de sentença em razão das alterações promovidas pela Lei n. ${ }^{\circ} 11.232 / 2005 .{ }^{31}$

\section{2- Em torno do conceito da fraude de execução}

Conceituar a fraude de execução não é tarefa fácil. O fenômeno abarca situações bastante distintas entre si e que nem sempre permaneceram as mesmas ao longo de sua história, ${ }^{32}$ sendo difícil encontrar um denominador comum entre todas as suas manifestações.

\footnotetext{
${ }^{30}$ Preferiu-se utilizar as denominações "terceiro imediato" e "terceiro mediato" nesta tese em lugar das expressões "terceiro adquirente" e "quarto adquirente", atualmente em voga. A razão da escolha se dá não apenas por se tratar de terminologia tradicional (cf. LOBÃO, Manuel de Almeida e Sousa. Tratado encyclopedico, pratico e critico sobre as execuções. Lisboa: Nacional, 1865. p. 66, § 59), mas também por ser tecnicamente mais adequada, evitando-se a mistura de termo ligado ao plano do direito processual ("terceiro") com expressão ligada ao direito material ("adquirente"), evitando-se também eventual equívoco de se entender que esse "terceiro adquirente" seria a terceira pessoa a adquirir o bem numa cadeia de transmissões.

${ }^{31}$ Sobre a terminologia adotada pela Lei n. ${ }^{\circ}$ 11.232/2005, cf. José Carlos Barbosa Moreira (Cumprimento e execução de sentença: necessidade de esclarecimentos conceituais. In: processual: nona série. São Paulo: Saraiva, 2007. p. 329-330).

${ }^{32}$ Conforme será analisado no capítulo 4, infra, situações que já foram consideradas pela legislação processual como fraude de execução hoje não mais o são e vice versa.
} 
Além disso, a dificuldade de se conceituar o instituto decorre de não haver uniformidade de sentidos, sendo a expressão fraude de execução empregada usualmente em três sentidos diversos, ora para designar o próprio ato que frustraria a atividade executiva; ${ }^{33}$ ora para designar o remédio processual existente para combater os efeitos danosos desse ato; ${ }^{34}$ ora, por fim, para significar a circunstância prevista em lei, que autorizará que o bem que dele é objeto seja alcançado pela atividade jurisdicional executiva decorrente de processo em curso. É este último o sentido empregado pelo Código de Processo Civil ${ }^{35}$ e que será adotado nesta tese.

O direito de executar bens alienados ou onerados em fraude de execução é instituto que se insere no contexto da efetividade do processo, tendo por objetivo garantir que a atividade jurisdicional executiva não seja frustrada em razão da prática de atos de alienação de bens pelo devedor.

Segundo antiga lição de Philadelpho Azevedo, o direito de executar bens alienados em fraude de execução e a ação pauliana inserem-se, juntamente com a hipoteca judiciária, o arresto e o sequestro, na categoria dos meios para se evitar a frustração da atividade jurisdicional executiva. A diferença que aparta os dois primeiros

\footnotetext{
${ }^{33}$ É esse, por exemplo, o sentido empregado por Cledi de Fátima Manica Moscon ao conceituar a fraude de execução como o "ato ou conjunto de atos realizados na existência de demanda por quem é devedor, afastando a disponibilidade patrimonial de possível constrição judicial quando, em insolvência ou atingindo o resultado de levá-lo à insolvência pelo ato de transferência ou oneração, causando prejuízo ao credor, frustrando a execução e com isso afrontando o poder jurisdicional." (MOSCON, Cledi de Fátima Manica. Fraude de execução judicial, cit., p. 29).

${ }^{34}$ Diferentemente do que ocorre com a ação pauliana ou revocatória, que visa a combater a fraude contra credores, não se atribui qualquer denominação ao remédio processual utilizado pelo credor para declarar ineficaz o ato praticado em fraude de execução, sendo frequentemente utilizada, por metonímia ou sinédoque, o próprio termo fraude de execução para designá-lo. É esse o sentido encontrado, por exemplo, no conceito de José Sebastião de Oliveira, segundo o qual a fraude de execução seria "um instituto de direito público, inserido no direito processual civil, que tem por finalidade coibir e tornar ineficaz a prática de atos fraudulentos de disposição ou oneração de bens, de ordem patrimonial, levados a efeito por parte de quem já figura no pólo passivo de uma relação jurídica processual, como legitimado ordinário (devedor demandado), visando com isso impedir que a satisfação da pretensão deduzida em juízo por parte do autor da demanda (credor demandante), configurando verdadeiro atentado à dignidade da Justiça, cuja atividade jurisdicional já se encontrava em pleno desenvolvimento." (OLIVEIRA, José Sebastião de. Fraude à execução, cit., p. 64).

${ }^{35}$ É o sentido que se extrai do artigo 593 do Código de Processo Civil:

"Art. 593. Considera-se em fraude de execução a alienação ou oneração de bens:

I- quando sobre eles pender ação fundada em direito real;

II- quando, ao tempo da alienação ou oneração, corria contra o devedor demanda capaz de reduzi-lo à insolvência;

III- nos demais casos expressos em lei." (sem destaque no original).
} 
dos três últimos é que aqueles são meios repressivos contra essa frustração, enquanto estes são meios preventivos dela. ${ }^{36}$

De fato, tanto a ação pauliana quanto o direito de executar bens alienados em fraude de execução atuam posteriormente à prática do ato que poderia frustrar a atividade executiva. Já a hipoteca judiciária, o arresto e o sequestro são manejados anteriormente a tal ato, buscando exatamente obstar tal frustração.

O modo pelo qual os institutos da fraude de execução e da fraude contra credores garantem a efetividade do processo de execução consiste na criação de hipóteses excepcionais de responsabilidade executória de bens existentes em patrimônio de terceiro. Ou, para se valer da terminologia utilizada por LIEBMAN, ${ }^{37}$ operam mediante a criação de hipóteses de responsabilidade executória secundária, permitindo que os atos de execução incidam sobre bens existentes em patrimônio de terceiro, caso seu ingresso nesse patrimônio tenha se dado em circunstâncias específicas, expressamente previstas em lei. ${ }^{38}$

Como se sabe, no direito brasileiro, a regra geral da responsabilidade patrimonial ou responsabilidade executória enuncia que todos os bens existentes no patrimônio do devedor respondem pelo cumprimento de suas obrigações. ${ }^{39}$ A respeito dessa regra, ensina DinAMARCo que ela se divide "em duas proposições: a) todos os bens do devedor respondem por suas obrigações e b) somente os bens do devedor respondem por suas obrigações." 40

Entretanto, para cada uma dessas proposições a regra geral admite uma correspondente exceção: a primeira consiste na existência de bens que, embora presentes

\footnotetext{
${ }^{36}$ Cf. AZEVEDO, José Philadelpho de Barros e. Da fraude contra sentenças. Rio de Janeiro: Faculdade Livre do Rio de Janeiro, 1920. p. 7. Menciona o mesmo autor que o direito de executar bens alienados em fraude de execução na época, era a "última e eficaz trincheira" contra a fraude (op. cit., p. 18). Ainda no sentido do texto, cf. Amílcar de Castro: "os meios de combate à fraude, em geral, são preventivos ou repressivos; preventivos são o arresto, o seqüestro e a hipoteca judicial; e repressivos são o direito de penhorar bens alienados em fraude de execução e a lide pauliana exercida direta ou indiretamente, em concurso de credores (...), ou em contestação a embargos de terceiro" (CASTRO, Amílcar de. Comentários ao Código de Processo Civil, cit., v. 8, p. 90).

${ }^{37}$ LIEBMAN, Enrico Tullio. Processo de execução, cit., p. 95.

${ }^{38}$ Atualmente, as circunstâncias previstas como fraude de execução estão disciplinadas no artigo 593 do Código de Processo Civil e as de fraude contra credores, no artigo 158 e 159 do Código Civil.

${ }^{39}$ É o que estabelece o artigo 591 do Código de Processo Civil: "O devedor responde, para o cumprimento de suas obrigações, com todos os seus bens presentes e futuros, salvo as restrições estabelecidas em lei." E, da mesma forma, o artigo 391 do Código Civil: "Pelo inadimplemento das obrigações respondem todos os bens do devedor." Como se observa, a redação do artigo 391 do Código Civil é mais técnica, pois deixa claro que quem responde são "os bens", e não "o devedor", como prevê o artigo 591 do Código de Processo Civil.
} 
no patrimônio do devedor, não respondem por determinadas obrigações ${ }^{41}$ e a segunda consiste na existência de bens que, não obstante estejam fora do patrimônio do devedor em patrimônio de terceiro, portanto -, respondem por determinadas obrigações daquele. ${ }^{42}$ É nessa última exceção que se inserem os bens alienados em fraude de execução e em fraude contra credores. ${ }^{43}$

Pode-se dizer, portanto, que a fraude de execução e a fraude contra credores inserem-se no gênero das circunstâncias previstas em lei que autorizam o credor a fazer uso de meios repressivos contra a frustração da atividade jurisdicional executiva, permitindo a prática de atos executórios sobre bens existentes em patrimônio de terceiro.

Encontrado o gênero em que se insere a fraude de execução, ainda com o intuito de conceituá-la, é necessário diferenciá-la da outra espécie que também o compõe, qual seja, a fraude contra credores, o que novamente apresenta particular dificuldade em razão da evolução do entendimento científico sobre ambos os institutos.

Em geral, as diferenças apontadas entre fraude de execução e fraude contra credores dizem respeito: (i) à sua natureza, pois a primeira seria instituto de direito público e a segunda, de direito privado; (ii) à consequência do seu reconhecimento, pois a primeira seria causa de ineficácia do ato e a segunda, de sua anulabilidade; (iii) à forma de sua decretação, pois a primeira seria decretada no curso do próprio processo ou fase de execução e a segunda dependeria do ajuizamento de ação própria (a denominada ação pauliana); (iv) aos seus requisitos, dependendo a segunda da existência do elemento subjetivo (comumente chamado de consilium fraudis) e a primeira não; e (v) ao momento

\footnotetext{
${ }^{40}$ DINAMARCO, Cândido Rangel. Execução civil. 8. ed. Paulo: Malheiros, 2002. p. 256.

${ }^{41}$ São exemplos dessa situação os bens absolutamente impenhoráveis (art. 650, CPC), o bem de família previsto na lei n. ${ }^{\circ} 8.009$, de 29 de março de 1990, entre outros (cf. lista bastante completa apresentada por CAHALI, Yussef Said. Fraudes contra credores, cit., p. 27-45 e, mais recentemente, também por Cândido Rangel Dinamarco, Bens impenhoráveis. In: Instituições de direito processual civil. 3. ed. São

Paulo: Malheiros, 2009. v. 4, p. 379-409).

${ }^{42}$ São exemplos dessa hipótese excepcional os direitos reais de garantia sobre bens alheios (v.g. hipoteca ou penhor de bem de terceiro) e, exceção feita ao caso do inciso III, as previstas no artigo 592 do Código de Processo Civil, que assim dispõe:

"Art. 592. Ficam sujeitos à execução os bens:

I- do sucessor a título singular, tratando-se de execução fundada em direito real ou obrigação reipersecutória;

II- do sócio, nos termos da lei;

III- do devedor, quando em poder de terceiros;

IV- do cônjuge, nos casos em que os seus bens próprios, reservados ou de sua meação respondem pela dívida;

V-alienados ou gravados com ônus real em fraude de execução."

${ }^{43}$ Exatamente por se tratar de hipóteses excepcionais à regra geral da responsabilidade executória, dependem de previsão expressa em lei, não admitindo interpretação ampliativa.
} 
em que ocorrem, sendo a primeira na pendência da ação cuja atividade executiva seria frustrada pela prática do ato de alienação e a segunda antes do ajuizamento da ação. ${ }^{44}$

No entanto, à luz do entendimento atualmente predominante sobre os dois institutos, nem todas as diferenças acima apontadas afiguram-se verdadeiras.

Inicialmente, pode-se dizer que a diferenciação dos dois institutos quanto à sua natureza, de direito público ou privado, é equivocada, pois tanto a fraude contra credores quanto a fraude de execução pertencem ao campo do direito público, uma vez que disciplinam hipóteses de extensão da responsabilidade executória, matéria que - como já há muito demonstrou CARNELUTTI, em evolução à teoria do Schuld und Haftung de ALOYS VON BRINZ - encontra-se exclusivamente no campo do direito processual. ${ }^{45}$ Nesse ponto, pouco importa que a fraude contra credores tradicionalmente seja prevista no Código Civil, diploma dedicado à disciplina de direito privado. Tal fato, que, em análise superficial pode induzir a equívocos, não é capaz de alterar a natureza do instituto. ${ }^{46}$

De igual modo, a diferenciação entre fraude de execução e fraude contra credores em relação aos seus efeitos não se sustenta, pois conforme a concepção da doutrina atual, também a decretação da fraude contra credores tem por consequência a ineficácia ou inoponibilidade do ato e não a sua anulação, como textualmente prevê o atual artigo 158 do Código Civil e, antes dele, previa o artigo 106 do código revogado. ${ }^{47}$

${ }^{44}$ Cf. CAHALI, Yussef Said. Fraudes contra credores, cit., 93-03 e COELHO JUNIOR, Sérgio. Fraude de execução e garantias fundamentais do processo, cit., p. 112. Em sentido semelhante, também o entendimento de Pontes de Miranda: "a fraude de execução é instituto de direito processual, que se não confunde, posto que em muitos pontos coincida com a fraude contra credores, que pertence ao direito material." (MIRANDA, Francisco Cavalcanti Pontes de. Comentários ao Código de Processo Civil, t. 9, p. 340).

${ }^{45}$ CARNELUTTI, Francesco. Lezioni di diritto processuale civile: processo di esecuzione. Padova: Cedam, 1932. v. 1, p. 68 e ss.

${ }^{46}$ Nesse sentido, sustenta Dinamarco que o erro de se considerar que os dois institutos têm naturezas distintas "é consequência de a fraude de execução e a fraude contra credores estarem disciplinadas em estatutos diferentes - aquela no Código de Processo Civil e esta, no Código Civil - embora ambas sejam institutos de natureza processual relacionados com a responsabilidade executiva." (DINAMARCO, Cândido Rangel. As fraudes do devedor, cit., p. 430). A situação é ainda comum em diversos ordenamentos em todo o mundo, como já se pôde verificar nas notas 15, 16 e 17, supra, em que matéria relativa à responsabilidade executória é tratada tanto em dispositivos dos códigos civis quanto processuais da Itália e de Portugal.

Há, ainda, autores que, embora reconheçam que ambos os institutos tenham a mesma natureza, rompem com o entendimento predominante no direito processual e questionam sua natureza pública, pois teriam por objetivo a proteção do interesse do autor (cf. SOUZA, Gelson Amaro de. Fraude de execução e o direito de defesa do adquirente, cit., p. 70-76 e COELHO JUNIOR, Sérgio. Fraude de execução e garantias fundamentais do processo, cit., p. 67).

${ }^{47}$ Defendem essa atual corrente THEODORO JÚNIOR, Humberto. Fraude contra credores: a natureza da sentença pauliana. 2. ed. Belo Horizonte: Del Rey, 2001. p. 242; HANADA, Nelson. Da insolvência e sua 
Defendendo o entendimento de que a sentença que reconhece a fraude contra credores e julga procedente a ação pauliana beneficia apenas o seu autor e não os outros credores, conclui a doutrina que o efeito dessa sentença opera exclusivamente no plano processual, tendo por efeito somente, nas palavras de LIEBMAN, "estender a ação e a responsabilidade executória a determinados bens de terceiro, precisamente aqueles que foram objeto do ato fraudulento." ${ }^{48}$ Noutros termos, a sentença que julga procedente a ação pauliana simplesmente mantém o bem alienado em fraude contra credores sujeito à atividade executiva, independentemente do seu ingresso em patrimônio de terceiro. ${ }^{49}$

Por fim, as três outras diferenças comumente apontadas entre os institutos: (i) o momento da realização do ato de alienação, (ii) a forma da decretação da ineficácia e (iii) a exigência ou não de demonstração do elemento subjetivo, decorrem todas de um elemento comum, este sim o único critério de diferenciação válido, qual seja, a pendência da ação em que se exercerá a atividade executiva que seria frustrada se o ato fraudulento produzisse seu efeito de subtrair o bem da responsabilidade patrimonial.

Com relação ao momento da prática do ato, a pendência da ação representa o marco divisório entre fraude contra credores e fraude de execução. Do mesmo modo, a pendência da ação acarreta a desnecessidade da instauração de outro processo para a decretação da ineficácia do ato. ${ }^{50}$ Por fim, tendo em vista a necessidade de registro no cartório distribuidor, a pendência da ação também influencia a análise sobre relevância do elemento subjetivo para a decretação da ineficácia do ato.

De fato, desde a promulgação do Código Civil de 1916 - quando, na maior parte do país, o direito processual ainda era regido pelo Regulamento 737, de 1850 -

prova na ação pauliana. 3. ed. São Paulo: Ed. Revista dos Tribunais, 1997. p. 92 e 127 e DINAMARCO, Cândido Rangel. As fraudes do devedor, cit., p. 423.

${ }^{48}$ LIEBMAN, Enrico Tullio. Processo de execução, cit., p. 106. Também nessa linha, CRUZ E TUCCI, José Rogério. Limites subjetivos da eficácia da sentença e da coisa julgada civil, cit., p. 203 e DINAMARCO, Cândido Rangel. As fraudes do devedor, cit., p. 438-439.

${ }^{49}$ Não se nega que a anulação do negócio jurídico, com o retorno do bem ao patrimônio do devedor alienante, também produz o efeito processual de sujeitar o bem à execução. No entanto, diferentemente da ação pauliana, no caso de uma ação anulatória do negócio jurídico (em razão de dolo, por exemplo), esse efeito processual não se produz isoladamente. Ele é reflexo ou derivado, pois decorre do retorno do bem ao patrimônio do devedor. Na hipótese de anulação do ato, portanto, o bem responde por força da regra geral da responsabilidade executória (art. 591, CPC), ou seja, responde como bem do devedor e não de terceiro.

${ }^{50}$ No caso da fraude contra credores, não estando em curso qualquer demanda judicial, a lei exige o ajuizamento da ação pauliana para que a decretação da ineficácia do ato se dê mediante o exercício do contraditório por parte do terceiro adquirente em cujo patrimônio o bem será alcançado pela atividade executiva. Ao contrário, no caso da fraude de execução, o reconhecimento da ineficácia ocorrerá incidentalmente, no próprio processo executivo, e eventual exercício do contraditório por parte do terceiro adquirente dar-se-á em processo autônomo de embargos de terceiro. 
a fraude de execução e a fraude contra credores já eram vistas como dois aspectos do mesmo fenômeno, diferenciados apenas pela existência de processo em curso. ${ }^{51}$

Assim, podemos conceituar fraude de execução como a circunstância expressamente prevista em lei e caracterizada pela existência de ação em curso, que autoriza o credor a fazer uso de meio repressivo contra a frustração da atividade jurisdicional executiva, fazendo a execução incidir sobre bens existentes em patrimônio de terceiro (alienação) ou desconsiderar direito real que beneficie terceiro (oneração).

É sob essa perspectiva que se deve analisar qual a feição e qual a relevância atribuída pela lei processual ao elemento subjetivo na fraude de execução, uma vez que, ao contrário da fraude contra credores, em que tais informações podem ser extraídas diretamente dos dispositivos do Código Civil, os artigos 592, V, e 593 do CPC não contêm previsão expressa nesse sentido, exigindo interpretação conjunta com outros dispositivos do mesmo código (artigos 659, § $4^{\circ}$, e 615-A) ou até mesmo de legislação extravagante (artigo 240 da Lei n. ${ }^{\circ} 6.015 / 1973$ ).

De fato, o artigo 158 do CC prevê que os atos gratuitos de alienação serão anulados (ou declarados ineficazes, para a corrente mais moderna) ainda que a insolvência seja ignorada pelo terceiro. Já o artigo 159 do mesmo código, prevê que, para a anulação (ou declaração de ineficácia) dos atos onerosos, a insolvência precisa ser notória ou haver motivo para que seja conhecida do outro contratante.

Ao contrário, o artigo 593 do CPC prevê apenas que se consideram em fraude de execução os atos de alienação praticados quando pendia ação fundada em direito real ou demanda capaz de reduzir o devedor à insolvência.

\footnotetext{
${ }^{51}$ Nesse sentido, Clóvis Beviláqua, ao comentar o artigo 106 que regulava a fraude contra credores no Código Civil revogado, afirmava: "um outro aspecto da fraude nas alienações é o que aparece no processo" (BEVILÁQUA, Clóvis. Código Civil dos Estados Unidos do Brasil. 2. ed. Rio de Janeiro: Ed. Rio, 1976. p. 359). Também já era esse o entendimento de Lafayette Rodrigues Pereira, segundo o qual "o direito de excutir bens alienados em fraude da execução não é senão a própria ação Pauliana exercida diretamente por via da penhora, independentemente do processo ordinário." (PEREIRA, Lafayette Rodrigues. Direito das coisas. Adaptação do Código Civil por José Bonifácio de Andrada e Silva. 5. ed. Rio de Janeiro: Freitas Bastos, 1943. v. 2, p. 179, nota 17 ao $§ 208$ ). A tendência de tratamento dos dois institutos como aspectos do mesmo fenômeno permanece ainda hoje, como se observa na recente lição de Dinamarco: "fraudes do devedor são as condutas com as quais alguém, na pendência, de uma obrigação insatisfeita, procura livrar um bem da responsabilidade patrimonial que pesa sobre ele (...). Essa expressão, não empregada em lei, serve para designar uma categoria ampla de condutas desse teor, na qual se incluem a fraude de execução, a fraude contra credores e a disposição de bem já constrito judicialmente" (DINAMARCO, Cândido Rangel. As fraudes do devedor, cit., p. 422).
} 
Com relação à fraude contra credores, com base nos artigos 158 e 159 do CC, ${ }^{52}$ o entendimento predominante, portanto, sustenta que, nos atos gratuitos, a presença do elemento subjetivo é irrelevante para a anulação do ato, bastando a demonstração da insolvência. ${ }^{53}$ Já para os atos onerosos, o elemento subjetivo é relevante e consiste na possibilidade de ciência da insolvência do devedor pelo outro contratante. ${ }^{54}$

Já no que diz respeito à fraude de execução, verifica-se que não há qualquer menção no texto do artigo 593 do Código de Processo Civil sobre em que consistiria tal elemento subjetivo, nem em que casos este seria relevante para a configuração da fraude. No entanto, os artigos $659, \S 4^{\circ}$, e $615-\mathrm{A}$, inseridos no mesmo código pelas reformas processuais de 1994, 2002 e 2006, dispõem que, da averbação da penhora ou do ajuizamento da execução nos cartórios de registros públicos, "presume-se o conhecimento de terceiro", indicando que tal requisito seria necessário para a configuração da fraude de execução.

\section{3- As hipóteses da fraude de execução na legislação atual}

Seguindo a tradicional estrutura das normas que disciplinam a fraude de execução, o Código de Processo Civil atual também dispõe sobre o tema em dois artigos que precisam ser conjugados, a saber, os artigos $592, \mathrm{~V}$, e $593,{ }^{55}$ assim redigidos:

\footnotetext{
52"Art. 158. Os negócios de transmissão gratuita de bens ou remissão de dívida, se os praticar o devedor já insolvente, ou por eles reduzido à insolvência, ainda quando o ignore, poderão ser anulados pelos credores quirografários, como lesivos dos seus direitos. (...)

Art. 159. Serão igualmente anuláveis os contratos onerosos do devedor insolvente, quando a insolvência for notória, ou houver motivo para ser conhecida do outro contratante."

${ }^{53}$ Nesse sentido, Yussef Said Cahali afirma que "legitima-se o credor para o exercício da ação pauliana, sendo indiferente que se prove que o devedor ou o terceiro beneficiário da gratuidade tenham ou devessem ter conhecimento do desfalque causado ao patrimônio assecuratório da dívida (...) mesmo de boa-fé aquele a ação procederá; portanto, no caso (...), considera-se que a fraude se constitui in re ipsa, pelo próprio fato de ser o devedor reduzido à insolvência, descartada qualquer consideração de ordem subjetiva" (CAHALI, Yussef Said. Fraudes contra credores, cit., p. 227).

${ }^{54}$ Novamente pertinente a lição de Yussef Said Cahali: "define o entendimento mais acertado, no sentido de que, quanto à sua participação, não se cogita da intenção de causar prejuízo (animus nocendi), mas tão somente do real ou presumível conhecimento de que o terceiro deve ter acerca da insolvência do devedor e do resultado que o ato ou contrato provocará para os credores deste" (CAHALI, Yussef Said. Fraudes contra credores, cit., p. 230).

${ }^{55}$ Sobre essa particularidade já se manifestou José Sebastião de Oliveira: "para que a fraude fique caracterizada depende da articulação de dois dispositivos processuais fundamentais: o art. 592, V, do Código de Processo Civil, que tem por finalidade específica indicar quais os bens que ficam afetados pela execução, mesmo que não mais pertençam ao devedor, ou que tenham sido por ele onerados; e o contido naquilo que prescreve qualquer um dos incisos do art. 593 do mesmo ordenamento, retratando a
} 
“Art. 592. Ficam sujeitos à execução os bens: (...)

V - alienados ou gravados com ônus real em fraude de execução.

Art. 593. Considera-se em fraude de execução a alienação ou oneração de bens:

I- quando sobre eles pender ação fundada em direito real;

II- quando, ao tempo da alienação ou oneração, corria contra o devedor demanda capaz de reduzi-lo à insolvência;

III- nos demais casos expressos em lei."

Como se observa, os bens alienados ou gravados com ônus real em fraude de execução ficam sujeitos à execução, juntamente com os bens do devedor (art. 591) e de outros responsáveis secundários nas situações previstas em lei, como os do sucessor a título singular, quando se tratar de execução fundada em direito real ou obrigação reipersecutória (art. 592, I), do sócio, nos termos da lei (art. 592, II) e do cônjuge, nos casos de seus bens próprios ou de sua meação (art. 592, IV). ${ }^{56}$

As circunstâncias que atualmente configuram alienação ou oneração em fraude de execução estão previstas nos incisos do artigo 593 e abrangem (i) a pendência de ação fundada em direito real que tenha por objeto aquele bem específico; (ii) a pendência de ação que possa reduzir o devedor à insolvência; e (iii) outros casos expressamente previstos em lei. Tais hipóteses serão tratadas especificamente a seguir.

\subsection{1- Pendência de ação fundada em direito real}

A hipótese prevista no artigo 593, I, do CPC refere-se à alienação do próprio bem objeto de ações fundadas em direitos reais, como os expressamente previstos no artigo 1.225 do $\mathrm{CC}$, quais sejam, (i) a propriedade; (ii) a superfície; (iii) as servidões;

oportunidade da alienação ou oneração e o efeito quanto à situação econômico-financeira do devedor." (OLIVEIRA, José Sebastião de. Fraude à execução, cit., p. 108).

${ }^{56}$ Deixou-se, propositalmente, de fazer menção à hipótese do art. 592, III, do CPC, que se refere ao "bens do devedor, quando em poder de terceiros", porque se trata de caso de responsabilidade primária, não secundária, pois tais bens ainda que estejam "em poder de terceiros", integram o patrimônio do devedor, e por isso já respondem por força da regra geral do art. 591, CPC. Da mesma forma, deixou-se de mencionar os bens reservados do cônjuge, pois tal figura, antes prevista no 246 do CC de 1916, não foi recepcionada pela Constituição da República de 1988, que em seus arts. $5^{\circ}$ e 226 equiparou homens e mulheres em direitos e obrigações, deixando de fazer sentido a reserva de bens apenas em favor de um deles. 
(iv) o usufruto; (v) o uso; (vi) a habitação; (vii) o direito do promitente comprador de imóvel; (viii) o penhor; (ix) a hipoteca; (x) a anticrese; (xi) a concessão especial para fins de moradia; e (xii) a concessão de direito real de uso. ${ }^{57}$

Nesse caso, o objeto da ação é um bem específico, portanto, a atividade executiva desenvolve-se diretamente sobre esse bem. Ou, como diz LIEBMAN, nessa primeira hipótese, o bem é o "objeto final da execução". ${ }^{58}$ Assim, a fraude de execução se dá por meio da alienação deste bem e não de outro qualquer. A fraude estará configurada, portanto, se o bem objeto da ação for alienado, independentemente do estado em que se encontrar o restante do patrimônio do devedor.

Há autores que apontam a existência de sobreposição entre a hipótese de fraude de execução prevista nesse artigo 593, I, e o caso de responsabilidade executória secundária previsto no artigo 592, I, do CPC, qual seja, o dos "bens do sucessor a título singular, tratando-se de execução fundada em direito real ou obrigação reipersecutória." ${ }^{59}$ Escrevendo à luz do Código de Processo Civil de 1939, o próprio LIEBMAN afirma textualmente que "a menção da ação real neste lugar [art. 593, I] parece supérflua, à vista do disposto no art. 888, I [art. 592, I], do Código de Processo Civil."60

Outros autores procuram separar as duas hipóteses em relação ao tempo em que o terceiro teria adquirido o bem. É o caso de ARAKEN DE ASSIS, ao afirmar que "distingue-se a hipótese versada no art. 592, I, submetendo o sucessor a título singular à força da sentença proferida em 'ação fundada em direito real', daquela contemplada no art. 593, I, que estima fraudulenta a alienação de bens 'quando sobre eles pender ação fundada em direito real', pelo momento da alienação: naquele, após a sentença; neste, no curso do processo de conhecimento." 61

\footnotetext{
${ }^{57}$ Embora prevaleça no direito brasileiro o princípio de que os direitos reais são previstos taxativamente em lei, o rol do artigo 1.225 do Código Civil não esgota todos os casos, pois, como esclarece Francisco Eduardo Loureiro, "há outros criados por leis especiais diversas, como, por exemplo, a alienação fiduciária sobre bens imóveis, regulada pela Lei n. 9.514/97, ou o compromisso de compra e venda de imóveis loteados, disciplinado pela Lei n. 6.766/79." (in Cezar Peluso (coord.), Código Civil Comentado, $3^{\mathrm{a}}$ ed., São Paulo: Manole, 2009, p. 1.156).

${ }^{58}$ LIEBMAN, Enrico Tullio. Processo de execução, cit., p. 109.

${ }^{59} \mathrm{~A}$ menção à "obrigação reipersecutória" na parte final do artigo 592, I, CPC foi introduzida recentemente pela Lei n. ${ }^{\circ} 11.382 / 2006$.

${ }^{60}$ LIEBMAN, Enrico Tullio. Processo de execução, cit., p. 108. Os primeiros colchetes, referentes ao artigo 593, foram acrescentados por nós para maior clareza; os segundos são originais e decorrem da atualização do Prof. Joaquim Munhoz de Mello.

${ }^{61}$ ASSIS, Araken de. Comentários ao Código de Processo Civil, cit., v. 4, p. 252. No mesmo sentido, THEODORO JÚNIOR, Humberto. Processo de execução. 21. ed. São Paulo: LEUD, 2002. p. 195.
} 
Tal diferenciação, contudo, não convence, pois a pendência da ação fundada em direito real permanece mesmo depois da sentença, o que igualmente faria coincidir a aplicação dos dois dispositivos.

Outros autores distinguem pelo modo como o bem objeto da ação fundada em direito real é adquirido. Assim, o artigo 592, I, referir-se-ia a casos de aquisições causa mortis, enquanto o artigo 593, I, ficaria reservado às aquisições por ato inter vivos. Entre os que assim entendem está AMÍLCAR DE CASTRO, para quem "sucessor a título singular é a pessoa a quem foi transferida, por causa da morte, determinada porção de bens." ${ }^{62}$

De fato, tal interpretação separa completamente as duas situações, mas o faz à custa de artificial restrição do sentido da expressão "sucessor a título singular", como se se referisse apenas a casos de aquisição causa mortis, como o legado.

É certo que a fraude de execução não se verifica em casos de transferência de propriedade causa mortis. Também é certo que o legatário é um "sucessor a título singular", mas está longe de ser o único. Conforme esclarece ALCIDES DE MENDONÇA Lima "sucessor singular é aquele que recebe, pelos meios legais permitidos, a transferência de bens certos (em sentido amplo) por qualquer título, v. g., venda, legado, dote, arrematação em hasta pública, dação in solutum, doação, permuta etc." ${ }^{63}$

Parece que o melhor, no caso, seria aceitar que realmente há certa superposição entre os artigos 592, I, e 593, I, do CPC e, ainda, entre esses dois dispositivos e os artigos 42, § $3^{\circ}, 568$, II, e 626 do mesmo código, ao estabelecerem, respectivamente, que "a sentença, proferida entre as partes originárias, estende seus efeitos ao adquirente ou ao cessionário [do bem litigioso]", que "são sujeitos passivos na execução o espólio, os herdeiros ou os sucessores do devedor" e que "alienada a coisa quando já litigiosa, expedir-

\footnotetext{
${ }^{62}$ CASTRO, Amílcar de. Comentários ao Código de Processo Civil, cit., v. 8, p. 69 - destaques no original. Também nesse mesmo sentido, cf. Teori Albino Zavascki, para quem "o mais adequado ao sistema é o entendimento segundo o qual a aquisição do bem litigioso, a que se refere o inciso I do art. 592, é a resultante do falecimento" (ZAVASCKI, Teori Albino. Comentários ao Código de Processo Civil. 2. ed. São Paulo: Ed. Revista dos Tribunais, 2003. v. 8, p. 253) e, já escrevendo após a alteração introduzida pela Lei n. ${ }^{\circ}$ 11.382/2006, Carlos Alberto Carmona: "havendo execução de título judicial ou extrajudicial fundado em direito real ou em obrigação reipersecutória (obrigação em que se pleiteia coisa que lhe pertence ou que lhe é devida, mas está em poder de terceiro), a morte do devedor e a transferência do bem para o patrimônio de terceiro (sucessor a título singular) não impedirá que tal bem seja objeto das medidas judiciais necessárias para o cumprimento da decisão exequenda ou da obrigação espelhada no título executivo extrajudicial (busca e apreensão, imissão de posse)." (in MARCATO, Antonio Carlos (Coord.). Código de Processo Civil interpretado. 3. ed. São Paulo: Atlas, 2008. p. 1.947).
} 
se-á mandado contra o terceiro adquirente, que somente será ouvido depois de depositá-la". A incidência desses últimos dispositivos chega até mesmo a colocar em dúvida se seria mesmo secundária ou se seria primária responsabilidade em tal hipótese.

Possível explicação para essa superposição de normas é encontrada na história do instituto. Conforme será analisado no item 4.1, infra, em 1850, quando surge a fraude de execução no direito processual brasileiro, ainda inexistia clareza na distinção científica entre débito e responsabilidade, ${ }^{64}$ de modo que as hipóteses de fraude de execução eram tratadas na norma que dispunha sobre os legitimados passivos da execução, entre os quais estava o sucessor singular quanto à ação fundada em direito real. ${ }^{65}$

Ao que tudo indica, ao longo da evolução do Direito Processual brasileiro, a regra original de 1850 (artigo 492 do Regulamento 737) desdobrou-se em duas, uma que disciplina a legitimidade passiva da execução (cf. atual art. 568, CPC) e outra que disciplina os casos dos bens sujeitos à execução (cf. atuais arts. 591 e 592, CPC). Ocorre que em alguns casos - e provavelmente este e o dos bens do devedor em poder de terceiros ( $\$ 7^{\circ}$ do Reg. 737 e art. 592, III, CPC) são dois deles - a hipótese não foi bem alocada ou acabou sendo repetida nos dois dispositivos, ainda que com redação diversa.

\footnotetext{
${ }^{63}$ LIMA, Alcides de Mendonça. Comentários ao Código de Processo Civil, cit., v. 6, t. 2, p. 538.

${ }^{64}$ Como se sabe, a obra de Aloys von Brinz, Lehrbuch der Pandekten, a que se atribui a diferenciação e identificação do débito (Schuld) e da responsabilidade (Haftung), só viria a ser publicada depois, em 1879.

${ }^{65} \mathrm{Cf}$. o que dispunha o artigo $492^{\circ}$ do Regulamento $737 / 1850$, que integrava o capítulo que tratava do juiz $e$ das partes competentes para a execução:

"Art. $492^{\circ}$ É competente a execução contra:

$\S 1^{\circ}$ A parte vencida;

$\S 2^{\circ}$ Os herdeiros ou sucessores universaes;

$\S 3^{\circ} \mathrm{O}$ fiador (arts. $496^{\circ} 591^{\circ}$ );

$\S 4^{\circ} \mathrm{O}$ chamado a autoria;

$\S 5^{\circ} \mathrm{O}$ successor singular, sendo a acção real;

$\S 6^{\circ} \mathrm{O}$ comprador ou possuidor de bens hypothecados, segurados, ou alienados em fraude de execução (art. 494. ${ }^{\circ}$ ); e em geral contra todos que recebem causa do vencido, como o comprador da herança;

$\S 7^{\circ}$ Todos os que detêm os bens em nome do vencido, como o depositario, o rendeiro, o inquilino, quanto a esses bens sómente;

$\S 8^{\circ} \mathrm{O}$ sócio (arts. $497^{\circ}, 498^{\circ}$ e $499^{\circ}$ ).

(...)

Art. $494^{\circ}$ Consideram-se alienados em fraude de execução os bens do executado:

$\S 1^{\circ}$ Quando são litigiosos, ou sobre eles pende demanda; (...)"
} 


\subsection{2- Pendência de ação que possa reduzir o devedor à insolvência}

O inciso II do artigo 593 do CPC prevê o caso mais comum de fraude de execução, e também o que provoca o maior número de discussões. Trata-se da alienação de bens no curso de ação capaz de reduzir o devedor à insolvência.

Enquanto no inciso I do artigo 593, o legislador foi específico em relação às ações que podem dar ensejo àquela modalidade de fraude de execução, limitando-as àquelas fundadas em direito real, no inciso II, a hipótese é genérica, bastando apenas que a ação pendente possa gerar atividade executiva para pagamento de quantia e que o valor do crédito seja tal que não exista no patrimônio do devedor bens passíveis de penhora suficientes para satisfazê-lo.

Novamente oportuna, aqui, a lição de LIEBMAN, considerando que esta segunda hipótese de fraude de execução decorre da alienação de bens que constituam "objeto instrumental da execução". ${ }^{66}$ A utilização do adjetivo "instrumental" pelo autor explica-se em razão de aqueles bens não serem os próprios objetos da prestação a que estava obrigado o devedor, servindo apenas como meio para que de sua expropriação se possa extrair a quantia necessária para o cumprimento da obrigação. ${ }^{67}$

Quanto à natureza da demanda pendente, afirma AlCIDES DE MENDONÇA LIMA que esta é "em regra, a condenatória, pois será apenas a única que poderá visar à alteração no patrimônio do devedor pela satisfação do respectivo quantum." No entanto, esse autor também admite a possibilidade da ocorrência dessa hipótese de fraude de execução "em ação meramente declaratória ou em ação constitutiva", diante da "possibilidade de condenação em pedidos acessórios, de cunho processual" e, finalmente, também em caso de pendência de ação penal, "se já houver sentença criminal condenatória com trânsito em julgado, habilitando o ofendido a executá-la no juízo cível."68

Apenas à necessidade de trânsito em julgado da sentença penal, discordamos do autor, entendendo, com DinAmARCO, que "um ato de disposição realizado

\footnotetext{
${ }^{66}$ LIEBMAN, Enrico Tullio. Processo de execução, cit., p. 109.

${ }^{67} \mathrm{O}$ que é feito, atualmente, por meio de uma das formas previstas nos artigos 685-A a 707 do Código de Processo Civil.

${ }^{68}$ LIMA, Alcides de Mendonça. Comentários ao Código de Processo Civil, cit., v. 6, t. 2, p. 572-574.
} 
depois de instaurado o processo crime também é, em princípio, apto a frustrar uma futura execução, qualificando-se por isso como fraude a esta." ${ }^{, 69}$

Realmente, mesmo as execuções de sentenças penais, arbitrais $^{70}$ ou estrangeiras homologadas $^{71}$ (arts. 475-N, II, IV e VI, CPC) podem ser frustradas, podendo ocorrer fraude de execução durante o curso do processo nas quais sejam proferidas.

$\mathrm{O}$ artigo 593, II, do CPC exige apenas a pendência de ação que possa reduzir o devedor à insolvência, o que evoca a ideia de ação que possa gerar atividade executiva de obrigação de pagar quantia. O texto legal não traz qualquer outra condicionante, podendo tratar-se de ação condenatória, constitutiva, declaratória, executiva, mandamental ou cautelar. ${ }^{72}$

${ }^{69}$ DINAMARCO, Cândido Rangel. As fraudes do devedor, cit., p. 442.

${ }^{70}$ Admitindo fraude de execução no curso da arbitragem, cf. Joel Dias Figueira Júnior: "“o árbitro ou tribunal arbitral detém uma parcela da jurisdição (...) e a sentença que vierem a proferir produzirá entre os litigantes e seus sucessores os mesmos efeitos da decisão que seria proferida pelos órgãos do Poder Judiciário, assim como a alienação ou oneração de bens durante o processo arbitral poderá ensejar a fraude de execução" (FIGUEIRA JUNIOR, Joel Dias. Arbitragem: Jurisdição e Execução. São Paulo: Ed. Revista dos Tribunais, 1999. p. 275). Comungam desse mesmo entendimento, AMENDOEIRA JUNIOR, Sidnei. Execução e Impugnação da Sentença Arbitral. In: SHIMURA, Sérgio; WAMBIER, Teresa Arruda Alvim (Coords.). Processo de execução e assuntos afins. cit. p. 708 e CAIS, Frederico Fontoura da Silva. Fraude de Execução, cit., p. 149.

${ }^{71}$ Nesse caso, parece-nos que, em razão do artigo 90 do CPC, somente estará constituída a fraude de execução durante o curso da ação homologatória perante o Superior Tribunal de Justiça e não da própria ação estrangeira em seu país de origem. Reconhecendo a fraude de execução em caso de homologação de sentença estrangeira, cf. STJ, $4^{\mathrm{a}}$ T., REsp. 182.099/SP, rel. Min. Ruy Rosado de Aguiar, j. 03.11.98, afirmando que: "a doação para a filha, com evidente propósito de prejudicar os credores, ocorreu na pendência de demanda (homologação de sentença estrangeira), capaz de levar o réu à insolvência, que, aliás, já era notória."

${ }^{72}$ Nesse sentido, cf. Araken de Assis: "não cogita o dispositivo da natureza virtual da demanda ou da lide. Além das ações condenatórias, cujo caráter patrimonial naturalmente provocam semelhante estado [de insolvência], outras ações, penais ou civis, constitutivas (v.g. separação ou divórcio), declaratórias, executivas ou mandamentais, ensejam o resultado coibido pelo instituto." (ASSIS, Araken de. Manual do processo de execução. 8. ed. São Paulo: Ed. Revista dos Tribunais, 2002. p. 453). Essa interpretação é praticamente unânime na doutrina, permanecendo constante desde a promulgação do Código de Processo Civil, cf. MOURA, Mário Aguiar. Fraude de execução pela insolvência do devedor, cit., p. 301; TEIXEIRA, Sálvio de Figueiredo. Fraude de execução, cit., p. 8; e DINAMARCO, Cândido Rangel. As fraudes do devedor, cit., p. 442. Talvez a única voz que se levanta contra tal entendimento seja a de Gelson Amaro de Souza, que defende a restrição da ocorrência da fraude de execução às "demandas executivas", afirmando que "quisesse o legislador que a expressão demanda pendente para efeito de fraude à execução fosse a demanda do processo de conhecimento, por certo teria feito tal alusão no Livro I, mais propriamente no art. 219, do CPC e não a reservado somente para o Livro II, referente ao processo de execução." (SOUZA, Gelson Amaro de. Fraude de execução e o direito de defesa do adquirente, cit., p. 80). Sem razão, contudo, esse último autor, pois, além de historicamente - mesmo no regime do artigo 895, II, do CPC revogado - ter prevalecido essa interpretação dado o objetivo do instituto de assegurar a eficácia do processo jurisdicional, atualmente, após a Lei n. ${ }^{\circ} 11.232 / 05$, em relação às execuções de títulos judiciais, a pendência da demanda ocorrerá efetivamente desde a fase de conhecimento, pois já não existe mais processo ou ação autônoma de execução nesse caso. 
Com exceção da ação que tenha por objeto principal do pedido a condenação do réu para o pagamento de quantia, ${ }^{73}$ nos demais casos, essa hipótese de fraude de execução decorrerá da possibilidade de frustração de atividade executiva que se baseie em condenações acessórias (v.g. verbas sucumbenciais, multas punitivas e coercitivas etc.) ou em condenações subsidiárias (v.g. conversão em perdas e danos das obrigações de fazer, não fazer e entregar coisa, cf. arts. 461, § 1º e 461-A, § $3^{\circ}, \mathrm{CPC}$ ).

Os protestos judiciais ou extrajudiciais e as medidas cautelares preparatórias, como o arresto ou o sequestro, não são aptos a ensejar fraude de execução a não ser em relação às condenações acessórias -, pois não constituem "demandas capazes de reduzir o devedor à insolvência", e sim atos que meramente as antecedem. ${ }^{74}$

É recorrente na doutrina a observação de que "não é a demanda em si que reduz o devedor à insolvência, mas o ato de alienação ou de oneração que se efetivou no seu curso." ${ }^{, 75}$ Tal observação não deixa de ser correta, mas não exprime totalmente a ideia em que se baseia essa hipótese de fraude de execução.

A circunstância prevista no inciso II do artigo 593 do CPC como caracterizadora de fraude de execução é a pendência, no momento da alienação, de ação capaz de reduzir o devedor à insolvência e não o fato - certamente mais grave, mas mais restrito - de o devedor ter efetivamente se reduzido à insolvência no curso da ação.

Equivale isso a dizer que o legislador quis levar em consideração o reflexo no patrimônio do devedor do resultado da ação em curso como se procedente fosse,

\footnotetext{
${ }^{73}$ Para os autores que sustentam que o legislador, com a "correção de linguagem" introduzida apenas no Senado Federal no artigo 475-N, I, do Código de Processo Civil, teria ampliado os limites do antigo artigo 584, I, abrangendo também as sentenças declaratórias como título executivo, leia-se também aqui as ações declaratórias que tenham por objeto o reconhecimento da existência de uma obrigação de pagar quantia. Não é essa, porém, a posição tecnicamente mais correta, como já demonstramos no nosso "O novo procedimento da execução de título executivo judicial de obrigação de pagar quantia. In: CARMONA, Carlos Alberto (Coord.). Reflexões sobre a reforma do Código de Processo Civil: estudos em homenagem a Ada Pellegrini Grinover, Cândido R. Dinamarco e Kazuo Watanabe. São Paulo: Atlas, 2007. p. 284-286", com base nos comentários específicos sobre essa alteração de Araken de Assis, Leonardo Greco e Cássio Scarpinella Bueno e nos fundamentos de José Ignacio Botelho de Mesquita e Amílcar de Castro.

${ }^{74}$ Nesse sentido, Alcides de Mendonça Lima: "nem o protesto cambiário, nem mesmo o judicial nem as próprias medidas preventivas servem para configurar a fraude de execução." (Comentários ao Código de Processo Civil, cit., v. 6, t. 2, p. 573). Há autores, no entanto, que defendem que tais atos têm o condão de antecipar o marco inicial da fraude de execução, trazendo-o para antes da propositura da ação que poderia reduzir o devedor à insolvência, desde que já fosse possível divisar qual seria o delineamento da ação condenatória a ser proposta (cf. ZAVASCKI, Teori Albino. Comentários ao Código de Processo Civil, cit., v. 8, p. 270-271).
} 
ainda que estivesse no início da fase de conhecimento. Somente assim pode-se aferir se o ato de alienação de bens frustraria a atividade executiva decorrente daquele processo.

Exemplificando: se, no momento da alienação, o devedor possuísse um patrimônio de $\mathrm{R}$ \$ 100.000,00 e tivesse sido proposta ação com o objetivo de condená-lo ao pagamento de indenização também no valor de $\mathrm{R} \$ 100.000,00$, qualquer alienação poderia ser considerada em fraude de execução ainda que não tivesse sido reconhecida judicialmente a existência da obrigação de indenizar, pois se a ação for julgada procedente, dando ensejo à atividade executiva, toda a alienação ocorrida durante o seu curso terá tido por consequência a criação ou o agravamento da insolvência do devedor.

Noutros termos, para se aferir se a ação pendente era "capaz de reduzir o devedor à insolvência" deve-se considerar a obrigação objeto dessa ação como já sendo certa - ou seja, existente - e líquida - isto é, de valor determinado -, quando da alienação.

\subsection{3- Outras hipóteses expressamente previstas em lei}

Além das hipóteses de fraude de execução previstas nos inciso I e II, o artigo 593 do CPC remete, em seu inciso III, a "demais casos expressos em lei".

Atualmente, com alguma variação entre os autores, são considerados abrangidos nesse inciso III as seguintes situações: (i) quitação pelo devedor de débito de terceiro penhorado (art. 672, § $3^{\circ}$, CPC); (ii) alienação de bens no período suspeito da falência (art. 129 da Lei n. ${ }^{\circ}$ 11.101/2005); (iii) alienação de bens pelo devedor após a inscrição de crédito tributário como dívida ativa (art. 185 do CTN); (iv) transferência da residência familiar para imóvel mais valioso adquirido pelo devedor mesmo sabendo-se insolvente (art. $4^{\circ}$ da Lei n. ${ }^{\circ}$ 8.009/1990); e (v) alienação de bem penhorado, arrestado ou sequestrado (art. 240 da Lei n. ${ }^{\circ}$ 6.015/1973).

Há autores, como Frederico FonTOura da Silva CAIS, que sustentam que "o disposto no inciso III do art. 593 do Código de Processo vai mais além e abrange não só os casos expressos em lei, como também outros, não normatizados mas que pela

\footnotetext{
${ }^{75}$ Cf. LIMA, Alcides de Mendonça. Comentários ao Código de Processo Civil, v. 6, t. 2, p. 574 e, mais recentemente, entre diversos outros, CAIS, Frederico Fontoura da Silva. Fraude de execução, cit., p. 149 e PEÑA, Ricardo Chemale Selistre. Fraude à execução, cit., p. 87.
} 
lógica do sistema são tipicamente de fraude de execução por atenderem aos requisitos do 'processo pendente' e da 'frustração dos meios executórios'". ${ }^{76}$

Não parece, contudo, ser essa a melhor interpretação. Conforme visto, os bens alienados em fraude de execução inserem-se entre as hipóteses de responsabilidade executória secundária (art. 592, V, CPC) que, por sua vez, configura exceção à regra geral da responsabilidade patrimonial de que os bens do devedor respondem para o cumprimento forçado de suas obrigações (art. 591, CPC e 391, CC). Por essa razão, tratando-se de norma que estabelece exceção, é vedada a interpretação ampliativa. ${ }^{77}$

Não obsta tal conclusão o fato de o artigo 593 do Código de Processo Civil não conter rol com todas as hipóteses de fraude de execução. A regra do inciso III, ainda que remissiva, refere-se a casos "expressamente" previstos em lei, o que torna o conjunto de hipóteses de fraude de execução - e, por consequência, o conjunto de casos de responsabilidade executória secundária - necessariamente finito, ainda que possa ser ampliado ou diminuído pelo legislador.

\subsubsection{1- Quitação pelo devedor de débito de terceiro penhorado}

A primeira hipótese de fraude de execução fora do artigo 593 encontra-se prevista no próprio Código de Processo Civil, em seu artigo $672, \S 3^{\circ}$, que assim dispõe:

\footnotetext{
"Art. 672. A penhora de crédito, representada por letra de câmbio, nota promissória, duplicata, cheque ou outros títulos, far-se-á pela apreensão do documento, esteja ou não em poder do devedor. (...)

$\S 3^{\circ}$ Se o terceiro negar o débito em conluio com o devedor, a quitação, que este lhe der, considerar-se-á em fraude de execução."
}

A situação descrita na norma é a seguinte: pretendendo-se a penhora sobre crédito do devedor contra terceiro, representado por nota promissória ou outro título de crédito, ambos deverão ser intimados na forma do artigo 671 do CPC. O primeiro para

\footnotetext{
${ }^{76}$ CAIS, Frederico Fontoura da Silva. Fraude de execução, cit., p. 165.

${ }^{77}$ Nesse sentido, a clássica lição de Carlos Maximiliano: "'leges quoe poenam statuunt, aut liberum jurium exercitium coarctant, aut exceptionem a lege continent, strictae subsunt interpretation' ('As normas positivas que estabelecem pena, restringem o livre exercício dos direitos, ou contêm exceção a lei,
} 
que não pratique ato de disposição do crédito, e o segundo, para que não pague diretamente ao devedor (seu credor), e sim deposite em juízo a importância da dívida, pois esta é a única forma pela qual se exonerará da obrigação (cf. art. 672, § $2^{\circ}, \mathrm{CPC}$ ).

No entanto, se o devedor der quitação ao terceiro, essa será considerada em fraude de execução, sendo, portanto, inoponível em relação à atividade executiva oriunda daquele processo.

A hipótese não deixa de equivaler à alienação de um bem pelo devedor, pois como afirma YUSSEF SAID CAHALI, "no ativo do patrimônio do devedor encontram-se não só bens corpóreos como incorpóreos, representados esses por direitos de crédito." ${ }^{78}$ No entanto, dada a especificidade da situação, essa tradicionalmente foi tratada em separado, como já ocorria no parágrafo único do artigo 950 do Código de Processo Civil e Comercial de São Paulo e no artigo 839 do Código de Processo Civil de 1939.

\subsubsection{2- Alienação de bens dentro do termo legal da falência}

A segunda hipótese de casos de fraude de execução a que se refere o artigo 593, III, do CPC, trata da alienação ou oneração de bens praticados nos casos previstos no artigo 129 da Lei n. ${ }^{\circ} 11.101 / 2005$, quais sejam:

\footnotetext{
"Art. 129. São ineficazes em relação à massa falida, tenha ou não o contratante conhecimento do estado de crise econômico-financeira do devedor, seja ou não intenção deste fraudar credores:

I - o pagamento de dívidas não vencidas realizado pelo devedor dentro do termo legal, por qualquer meio extintivo do direito de crédito, ainda que pelo desconto do próprio título;

II - o pagamento de dívidas vencidas e exigíveis realizado dentro do termo legal, por qualquer forma que não seja a prevista pelo contrato;

III - a constituição de direito real de garantia, inclusive a retenção, dentro do termo legal, tratando-se de dívida contraída anteriormente; se os bens dados em hipoteca forem objeto de outras posteriores, a massa falida receberá a parte que devia caber ao credor da hipoteca revogada;

IV - a prática de atos a título gratuito, desde 2 (dois) anos antes da decretação da falência;
}

submetem-se a interpretação estrita')." (MAXIMILIANO, Carlos. Hermenêutica e aplicação do direito, cit., p. 184).

${ }^{78}$ CAHALI, Yussef Said. Fraudes contra credores, cit., p. 687. 
V - a renúncia à herança ou a legado, até 2 (dois) anos antes da decretação da falência;

VI - a venda ou transferência de estabelecimento feita sem o consentimento expresso ou o pagamento de todos os credores, a esse tempo existentes, não tendo restado ao devedor bens suficientes para solver o seu passivo, salvo se, no prazo de 30 (trinta) dias, não houver oposição dos credores, após serem devidamente notificados, judicialmente ou pelo oficial do registro de títulos e documentos;

VII - os registros de direitos reais e de transferência de propriedade entre vivos, por título oneroso ou gratuito, ou a averbação relativa a imóveis realizados após a decretação da falência, salvo se tiver havido prenotação anterior.

Parágrafo único. A ineficácia poderá ser declarada de ofício pelo juiz, alegada em defesa ou pleiteada mediante ação própria ou incidentalmente no curso do processo."

A hipótese foge da fisionomia da fraude de execução, pois o ato de alienação pode ocorrer antes da pendência de qualquer ação em juízo, uma vez que o termo legal da falência poderá ser fixado em até 90 dias contados do pedido de falência ou de recuperação judicial ou, ainda, do primeiro protesto por falta de pagamento (cf. art. 99, II, da Lei n. ${ }^{\text {11.101/2005). }}{ }^{79}$

Além disso, esse caso tem origem diversa dos outros casos de fraude de execução previstos no artigo 593 do CPC. Como será visto com maior detalhe no capítulo 4, infra, enquanto esses decorrem do Regulamento 737/1850, o caso sob análise é anterior, já sendo previsto pelo artigo $2^{\circ}$ Decreto $482 / 1846$ que regia o registro geral das hipotecas. ${ }^{80}$ Tal hipótese sempre teve regramento próprio no ordenamento jurídico brasileiro, sendo o Código de Processo Civil de 1939 muito criticado ao prevê-la em seu

\footnotetext{
${ }^{79}$ Comentando tal norma, justifica Ricardo Tepedino que "o estado de colapso patrimonial tem sempre um período de incubação, no qual a atividade da empresa se desenvolve de um modo mais ou menos anormal. Nesse período, são comuns certos procedimentos do empresário, seja em busca do seu soerguimento, seja para garantir o seu próprio futuro incerto: os truques mais variados são usados para levantar crédito, vendas se fazem a preço baixo, expedientes ruinosos são empregados para ostentar uma capacidade de pagar já não existente, ativos são desviados, credores prediletos ou coniventes são beneficiados - em suma, são encontradiços, nessa fase, todo um sortimento de atos que o devedor pode praticar em detrimento de seus credores, seja de boa ou má-fé." (in TOLEDO, Paulo F. C. Salles de; ABRÃO, Carlos Henrique (Coords.), Comentários à Lei de Recuperação de Empresas e Falência, São Paulo: Saraiva, 2005. p. 342).

80"Art. 2..$^{\circ}$ As hypothecas deverão ser registradas no Cartorio do Registro geral da Comarca onde forem situados os bens hypothecados. Fica porêm exceptuada desta regra a hypotheca que recahir sobre escravos, a qual deverá ser registrada, no registro da Comarca em que residir o devedor.

Não produzirá effeito o registro feito em outros Cartorios, e igualmente o que for feito dentro dos vinte dias anteriores ao fallimento."
} 
artigo 895, III, em claro bis in idem à norma já existente no Decreto n. ${ }^{\circ} 5.746$, de 9 de dezembro de 1929.

De fato, também em face à lei atual não se vislumbra qualquer utilidade em se dizer que esta seria uma hipótese expressamente prevista de fraude de execução. Ao contrário do artigo $672, \S 3^{\circ}$, do CPC, analisado acima, esse caso já prevê expressamente qual seria a consequência dos atos praticados nessa circunstância: "ineficácia em relação à massa falida", não precisando da interpretação conjunta com o artigo 592 do CPC.

De toda forma, vale ressaltar, aqui, que além da possibilidade de se considerar em fraude de execução atos anteriores ao ajuizamento de qualquer ação, essa hipótese apresenta, ainda, outras duas peculiaridades: (i) deixa expressamente clara a total irrelevância do elemento subjetivo para sua configuração, ao prever que os atos serão ineficazes "tenha ou não o contratante conhecimento do estado de crise econômicofinanceira do devedor, seja ou não intenção deste fraudar credores"; e (ii) prevê expressamente a possibilidade de ser reconhecida de ofício pelo juiz.

\subsubsection{3- Alienação de bens após a inscrição de crédito tributário como dívida ativa}

Uma terceira hipótese de fraude de execução que frequentemente se indica como inserida no artigo 593, III, do CPC está prevista no artigo 185 do Código Tributário Nacional, que, após a alteração pela Lei Complementar n. ${ }^{\circ} 118$, de 9 de setembro de 2005, passou a ter a seguinte redação:

\footnotetext{
"Art. 185 - Presume-se fraudulenta a alienação ou oneração de bens ou rendas, ou seu começo, por sujeito passivo em débito para com a Fazenda Pública, por crédito tributário regularmente inscrito como dívida ativa.

Parágrafo único. O disposto neste artigo não se aplica na hipótese de terem sido reservados, pelo devedor, bens ou rendas suficientes ao total pagamento da dívida inscrita."
}

A alteração da Lei Complementar n. ${ }^{\circ}$ 118/2005 consistiu em suprimir, da parte final do caput e do parágrafo único do artigo 185 do CTN, a expressão "em fase de execução", que deixava clara a exigência de já haver execução fiscal proposta para que se configurasse tal hipótese de fraude de execução. Assim, atualmente, basta a inscrição do 
crédito tributário na dívida ativa para que se presuma em fraude de execução a alienação dos bens do devedor. ${ }^{81}$

Embora já antes da alteração houvesse autores que defendessem a simples inscrição na dívida ativa como marco inicial da fraude de execução nesse caso, ${ }^{82}$ prevalecia o entendimento, inclusive no Superior Tribunal de Justiça, de que o CTN exigia o ajuizamento da execução fiscal, ${ }^{83}$ alterando-se depois para a citação do devedor ${ }^{84}$ e, mais recentemente, passado a exigir o registro da penhora ou prova da ciência do terceiro. ${ }^{85}$

Ao prever hipótese de fraude de execução antes mesmo do ajuizamento de demanda, a alteração do artigo 185 do CTN foge ao modelo do artigo 593 do CPC.

Além disso, como será visto no item 4.3, infra, a hipótese também já possuía existência independente das previstas no Código de Processo Civil, já estando disciplinada no artigo $2^{\circ}$ do Decreto n. ${ }^{\mathrm{o}} 22.866$, de 28 de junho de $1933,{ }^{86}$ antes de o código de 1939 prever no inciso IV de seu artigo 895 que se consideraria em fraude de execução outras hipóteses previstas em lei.

\footnotetext{
${ }^{81}$ Com essa alteração, pode-se dizer que a abrangência do artigo 185 do Código Tributário Nacional se sobrepôs à do artigo 47 da Lei n. ${ }^{\circ}$ 8.212, de 24 de julho de 1991, que prevê que a alienação de bens sem a obtenção de Certidão Negativa de Débitos seria ineficaz em relação ao Intituto Nacional de Seguridade Social. Muito embora a lei preveja a alienação seria "nula para todos os efeitos" (cf. artigo 48), prevalece o entendimento de que tal consequência tratar-se-ia de mera ineficácia (nesse sentido, cf. STJ, $4^{\mathrm{a}}$ T., REsp. 140.252/SP, rel. Min Sálvio de Figueiredo Teixeira, j. 09.12.97: "em interpretação teleológica dos arts. 47/48 da Lei 8.212/91, a falta de apresentação da certidão negativa de débito com o INSS faz o ato de alienação do imóvel ineficaz em relação à Seguridade Social, não impondo, entretanto, a sua nulidade" e STJ, $3^{a}$ T., REsp 92.500/AM, rel. Min. Eduardo Ribeiro, j. 04.02.97: "Alienação do imóvel. Contribuições Sociais. Certidão negativa. A falta de apresentação dessa certidão faz o ato ineficaz frente à Previdência, podendo proceder-se à penhora do bem como se alienação não tivesse havido").

${ }^{82}$ Cf. BÚRIGO, Vandré Augusto. A garantia do crédito tibutário: a presunção de fraude à execução. Revista Dialética de Direito Tributário, São Paulo, n. 92, p. 83, maio 2003.

${ }^{83}$ Cf. STJ, $1^{\mathrm{a}}$ T., REsp. 74.021/SP, rel. Min. Humberto Gomes de Barros, j. 13.12.95; STJ, $1^{\mathrm{a}}$ T., REsp. 119.979/MA, rel. Min. José Delgado, j. 25.09.97.

${ }^{84}$ Cf. STJ, $1{ }^{\text {a }}$ Seção, ERsp. 31.321/SP, rel. Min. Milton Luiz Pereira, j. 22.09.99.

${ }^{85} \mathrm{Cf}$. nesse sentido: "ficou superado o entendimento de que a alienação ou oneraçao patrimonial do devedor da Fazenda Pública após a distribuição da execução fiscal era o bastante para caracterizar fraude, em presunção jure et de jure. 3. Afastada a presunção, cabe ao credor comprovar que houve conluio entre alienante e adquirente para fraudar a ação de cobrança. 4. No caso de alienação de bens imóveis, na forma da legislação processual civil (art. 659, § $4^{\circ}$, do CPC, desde a redação da Lei 8.953/94), apenas a inscrição da penhora no competente cartório torna absoluta a assertiva de que a constrição é conhecida por terceiros e invalida a alegação de boa-fé do adquirente da propriedade. 5. Ausente o registro da penhora efetuada sobre o imóvel, não se pode supor que as partes contratantes agiram em consilium fraudis. Para tanto, é necessária a demonstração, por parte do credor, de que o comprador tinha conhecimento da existência de execução fiscal contra o alienante ou agiu em conluio com o devedor-vendedor, sendo insuficiente o argumento de que a venda foi realizada após a citação do executado." (STJ, $2^{\mathrm{a}}$ T., REsp 625.843/RS, rel. Min. Eliana Calmon, j. 23.05.06) e outros acórdãos da $1^{\mathrm{a}}$ e $2^{\mathrm{a}}$ Turmas do Superior Tribunal de Justiça que serviram de precedentes para a elaboração da súmula 375.

${ }^{86}$ Assim dispunha essa norma: "art. $2^{\circ}$ Consideram-se feitas em fraude da Fazenda Pública as alienações ou seu começo, realizadas pelo contribuinte em debito."
} 
A alteração da Lei Complementar n. ${ }^{\circ}$ 118/2005 pode, portanto, ser considerada como retrocesso em relação à evolução do instituto da fraude de execução, que acabou por fixar seu marco inicial na pendência de ação e não em atos anteriores a ela. $^{87}$

Se comparada com artigo $2^{\circ}$ do Decreto n. ${ }^{\circ} 22.866 / 1933$, contudo, uma vantagem que pode ser observada na redação atual do artigo 185 do CTN diz respeito à expressa previsão de presunção, o que já serviu para permitir a discussão sobre a presença do elemento subjetivo nessa hipótese de fraude de execução, conforme visto acima.

No tocante aos tributos federais, atualmente é fácil para eventual interessado saber da existência de débito tributário do alienante inscrito na dívida ativa, sendo até mesmo praxe a obtenção de certidão negativa de débitos federais, o que não torna de todo irrazoável a alteração aqui apontada. No entanto, o mesmo já não se pode dizer quanto às possíveis inscrições nas dívidas ativas estaduais e municipais, pois podem se dar em local diverso do domicílio do alienante ou do local do bem, o que deve ser analisado quando da aferição da presença do elemento subjetivo para a configuração dessa hipótese de fraude de execução.

\subsubsection{4- Transferência do bem de família para imóvel mais valioso?}

A quarta hipótese normalmente apontada como inserida no artigo 593, III, do CPC é a transferência da impenhorabilidade decorrente da caracterização do imóvel como bem de família para outro imóvel mais valioso, prevista no artigo $4^{\circ}$ da Lei n. ${ }^{\circ}$ 8.009/1990:

\footnotetext{
"Art. $4^{\circ}$. Não se beneficiará do disposto nesta Lei aquele que, sabendo-se insolvente, adquire de má-fé imóvel mais valioso para transferir a residência familiar, desfazendo-se ou não da moradia antiga.

$\S 1^{\circ}$. Neste caso poderá o juiz, na respectiva ação do credor, transferir a impenhorabilidade para a moradia familiar anterior, ou anular-lhe a venda, liberando a mais valiosa para execução ou concurso, conforme a hipótese.
}

$\S 2^{\circ}$. Quando a residência familiar constituir-se em imóvel rural, a impenhorabilidade restringir-se-á à sede de moradia, com os respectivos

\footnotetext{
${ }^{87}$ Similarmente ao que acontecia em outros casos, como da existência de protestos de títulos extrajudiciais na época dos Códigos Estaduais (cf. item 4.2, infra).
} 
bens imóveis, e, nos casos do art. $5^{\circ}$, inciso XXVI, da Constituição, à área limitada como pequena propriedade rural."

A hipótese aqui é visivelmente distinta das demais. Dada a impenhorabilidade do bem de família, o devedor concentra todo o seu patrimônio ou, ao menos, a maior parte de seu patrimônio sujeito à penhora em um único imóvel e transferindo para ele sua residência familiar.

A forma de frustrar a atividade executiva, nessa hipótese, não constitui, propriamente, alienação ou oneração do bem. O que faz o devedor é colocar ao abrigo da penhora, em razão da impenhorabilidade prevista no artigo $1^{\circ}$ da Lei n. ${ }^{\circ} 8.009 / 1990$, a parcela do patrimônio que serviria de garantia para seus credores.

Nota-se que o valor total do patrimônio do devedor não se altera - não há, portanto, que se cogitar da criação ou do agravamento de insolvência, pois essa já é pressuposta. O que se altera é a composição desse patrimônio; a distribuição, por assim dizer, entre o conjunto de bens passíveis de penhora e o núcleo impenhorável, com o aumento deste em detrimento daquele.

Obviamente, tal ato somente pode ser considerado em fraude de execução em relação a uma ação que decorra de obrigação diversa das previstas nos incisos do artigo $3^{\circ}$ da Lei n. ${ }^{\circ}$ 8.009/1990, que não se sujeitam a essa impenhorabilidade, quais sejam, (i) créditos de trabalhadores da própria residência; (ii) crédito decorrente do financiamento destinado à construção ou à aquisição do imóvel, no limite dos créditos e acréscimos constituídos em função do respectivo contrato; (iii) crédito de pensão alimentícia; (iv) créditos decorrentes de imposto predial ou territorial, taxas e contribuições devidas em função do imóvel familiar; (v) crédito hipotecário sobre o imóvel oferecido como garantia real pelo casal ou pela entidade familiar; (vi) pretensão penal buscando reaver produto de crime ou execução de sentença penal condenatória e ressarcimento, indenização ou perdimento de bens; e (vii) obrigação decorrente de fiança em contrato de locação.

Para essas obrigações, a impenhorabilidade não pode ser oposta, de modo que a concentração do patrimônio do devedor no bem de família, mediante a aquisição de imóvel de maior valor, ser-lhes-á indiferente. Para os demais casos, a própria Lei n. ${ }^{\circ}$ 
8.009/1990 prevê em seu artigo $4^{\circ}, \S 1^{\circ}$, o modo de repressão à frustração que decorreria do ato do devedor: se houve simples transferência da residência familiar, com a manutenção, no patrimônio do devedor, do imóvel em que esta estava instalada, o juiz simplesmente deslocará a impenhorabilidade para o imóvel anterior, procedendo-se à penhora como se a transferência não houvesse ocorrido.

Ao contrário, se o imóvel onde estava instalada a residência familiar anterior foi alienado, prevê o referido $\S 1^{\circ}$, parte final, que tal alienação deverá ser anulada, com o retorno do antigo imóvel ao devedor e deslocamento da impenhorabilidade para ele, como na hipótese anterior. Criticando tal norma, ARAKEN DE ASSIS afirma que "solução bem mais vantajosa, do ponto de vista técnico, residiria na simples eliminação da impenhorabilidade da nova moradia, deixando o terceiro em paz" e, em seguida, completa: "tangendo-se à anulação, e não ineficácia (...), o juiz deverá resguardar o direito do terceiro à restituição integral de sua prestação no negócio". ${ }^{88}$

De fato, o ideal seria que simplesmente se permitisse que a execução se fizesse sobre o imóvel em que se instalou o bem de família, garantindo-se ao devedor o valor referente ao imóvel em que antes residia sobre o produto da alienação judicial. Evitar-se-ia com isso a anulação do negócio feito com o terceiro. Além disso, prevendo a lei a anulação - e não de mero reconhecimento de inoponibilidade - seria necessária a propositura de ação específica, com a inclusão do terceiro como litisconsorte necessário.

De toda forma, além de ser muito diversa das demais, essa hipótese não pode ser considerada inserida entre as do inciso III do artigo 593, CPC pois a Lei n. ${ }^{\circ}$ 8.009/1990 sequer prevê expressamente esse caso como fraude de execução.

\subsubsection{5- Alienação de bem penhorado, arrestado ou sequestrado?}

Por fim, a quinta hipótese que geralmente se aponta como referida no artigo 593, III, do CPC seria a alienação de bens penhorados, arrestados ou sequestrados.

Não há, contudo, consenso entre os autores sobre se tal caso efetivamente configuraria hipótese de fraude de execução ou se seria hipótese sui generis de ineficácia.

\footnotetext{
${ }^{88}$ ASSIS, Araken de. Manual do processo de execução, cit., p. 460-461.
} 
Defendendo a inclusão da alienação do bem constrito entre os atos praticados em fraude de execução, além de AmílCAR DE CASTRO ${ }^{89}$ e LuIZ FuX, ${ }^{90}$ já citados, estão AraKen de Assis, ${ }^{91}$ Humberto TheOdoro JÚnior, ${ }^{92}$ Nelson NERY Júnior, ${ }^{93}$ SÉrgio Shimura, ${ }^{94}$ Pedro Belmiro Welter ${ }^{95}$ e Ricardo Chemale SElistre PeÑa. ${ }^{96}$

Em sentido contrário, sustentando que a alienação de bem constrito não se insere entre os casos de fraude de execução, estão LIEBMAN, ${ }^{97}$ YUSSEF SAID CAHALI, ${ }^{98}$ SÁlVio de Figueiredo TEIXEIRA ${ }^{99}$ e DinAMARCO. ${ }^{100}$

${ }^{89}$ CASTRO, Amílcar de. Comentários ao Código de Processo Civil, cit., v. 8, p. 88.

${ }^{90}$ FUX, Luiz. O novo processo de execução: o cumprimento da sentença e a execução extrajudicial, cit., p. 100.

91"Em que pese ausente dos números do art. 593 do CPC, a alienação ou a oneração do bem objeto de penhora ou de arresto, com redobradas razões, também se afigura ineficaz." (ASSIS, Araken de. Manual do processo de execução, cit., p. 454-455).

${ }^{92 " S e}$ houver (...) vinculação do bem alienado ou onerado ao processo fraudado (como por exemplo: penhora, arresto ou sequiestro), a caracterização da fraude de execução independe de qualquer outra prova. $\mathrm{O}$ gravame judicial acompanha o bem perseguindo-o no poder de quem quer que o detenha, mesmo que o alienante seja um devedor solvente." (THEODORO JÚNIOR, Humberto. Processo de execução, cit., p. 196).

93،"Alienação de bem penhorado é forma grave de fraude de execução, que se caracteriza independentemente de o devedor estar ou não insolvente" (NERY JR., Nelson. Código de Processo Civil Comentado. 10. ed. São Paulo: Ed. Revista dos Tribunais, 2007. p. 1.003).

94"Alienado ou onerado um bem arrestado, é de considerar-se fraude à execução, à luz do art. 593, CPC? A resposta é positiva. (...) Estando vinculado o bem alienado ou onerado ao processo fraudulento (como, por exemplo, penhora, arresto ou sequestro), a caracterização da fraude de execução independe de qualquer outra prova. O gravame judicial acompanha o bem, perseguindo-o no poder de quem quer que o detenha, mesmo que o alienando seja devedor solvente. Como corolário, lógico que se confira ao ato fraudulento do devedor arrestado a tisna de fraude de execução." (SHIMURA, Sérgio. Arresto cautelar. 3. ed. São Paulo: Ed. Revista dos Tribunais, 2005. p. 615-616).

${ }^{95}$ Pedro Belmiro Welter tem posição bastante peculiar sobre o instituto, entendendo haver três tipos de fraude de execução, com efeitos e requisitos distintos, sendo um deles precisamente esse caso de alienação de bens constritos, ao qual denominou de "fraude contra o poder jurisdicional do Estado". Mais especificamente, para esse autor, os três tipos de fraude de execução seriam:

"a) se há registro de algum ato processual, há, efetivamente fraude de execução (latu sensu), mas não a do artigo 593, II, do CPC, e sim fraude contra o Direito Registral (artigo 240 da lei dos registros públicos);

b) quando não há registro, mas aparelhamento de penhora, seqüestro ou arresto, ou qualquer outra constrição judicial, há fraude de execução (no sentido amplo), mas não a do artigo 593, II, e sim fraude contra o poder jurisdicional do Estado (artigo 601, I, do CPC);

c) quando não há registro, nem gravame (penhora etc.), mas somente pendência de demanda , aí sim ocorre a legítima e genuína fraude à execução (em sentido restrito) do artigo 593, II, do CPC." (WELTER, Belmiro Pedro. Fraude de execução. 3. ed. Porto Alegre: Síntese, 1998. p. 12).

96"A alienação de bens já constritos por medidas judiciais pode ser caracterizada como uma espécie de fraude à execução, não prevista na legislação, muito embora se possa qualificar como uma das mais graves infrações fraudulentas." (PEÑA, Ricardo Chemale Selistre. Fraude à execução, cit., p. 96-97).

97"É frequente nos escritores e julgados a afirmação de que as alienações de bens penhorados não valeriam porque feitas em fraude de execução. Mas, como se explica no texto, neste caso as alienações são ineficazes em face da execução por efeito do vínculo imposto sobre os bens pela penhora, sem depender da fraude nem de seus requisitos." (LIEBMAN, Enrico Tullio. Processo de execução, cit., p. 127).

98"A alienação do bem penhorado (ou arrestado) não se insere na provisão do art. 593, II, do CPC, nem tipifica modalidade de fraude de execução: os bens constritados ficam submetidos ao poder jurisdicional do Estado; a apreensão da coisa é ato formal e solene, de tal modo que se considera ineficaz perante o credor qualquer ato de disposição da mesma a que se proponha o devedor." (CAHALI, Yussef Said. Fraudes contra credores, cit., p. 589). 
A razão está com esses últimos, pois, como será analisado no capítulo 4, infra, desde 1939, a legislação brasileira não prevê expressamente a alienação do bem constrito como hipótese de fraude de execução. ${ }^{101}$

O dispositivo legal normalmente invocado pelos autores que defendem a inclusão da alienação de bem penhorado no artigo 593, III, do CPC é o artigo 240 da Lei n. ${ }^{\circ}$ 6.015/1973 que não descreve caso de fraude de execução, mas prevê apenas que "o registro da penhora faz prova quanto à fraude de qualquer transação posterior."

\section{4- Conclusões preliminares sobre a fraude de execução}

Diante do exposto até o momento, pode-se concluir que sob a denominação de fraude de execução o legislador designa diversas circunstâncias expressamente previstas em lei em que bens do devedor alienados a terceiro permanecem sujeitos à atividade jurisdicional executiva decorrente de uma ação em curso ainda que estejam no patrimônio deste.

Tais circunstâncias são a pendência de ação fundada em direito real sobre o bem (art. 593, I, CPC); a pendência de ação que possa reduzir o devedor à insolvência (art. 593, II, CPC) e outras expressamente previstas em lei (art. 593, III, CPC).

Entre as normalmente apontadas como inseridas nessa regra genérica do inciso III, persistem, pela análise feita, apenas: (i) a quitação pelo devedor de débito de terceiro penhorado (art. 672, § $3^{\circ}$, CPC); (ii) o período suspeito da falência (art. 129, Lei n. $\left.{ }^{\circ} 11.101 / 2005\right)$; e (iii) a inscrição do crédito tributário na dívida ativa (art. 185, CTN).

\footnotetext{
99" Os estudos sobre a fraude de execução sempre versam os casos de alienação ou oneração de bens sujeitos a penhora, arresto ou seqüestro, muito deles incluindo-os na rubrica do n. II do art. 593 do CPC. No entanto, em face da redação dada ao referido inciso, a hipótese não está ali contida. A alienação ou oneração é, aí, ineficaz em relação ao exeqüente porque decorre da circunstância de o bem estar submetido ao poder jurisdicional do Estado, através de ato público formal e solene." (TEIXEIRA, Sálvio de Figueiredo. Fraude de execução, cit., p. 9-10).

${ }^{100}$ Dinamarco diferencia ao menos três espécies de fraudes do devedor, quais sejam, a fraude contra credores, a fraude de execução e a alienação de bem penhorado, mencionando que esta última configura "atentado ao estado de concreta sujeição do bem, e não apenas tentativa de subtrair bem responsável e ainda não constrito (fraude de execução, CPC 593)." (DINAMARCO, Cândido Rangel. Execução civil, cit., p. 304).

${ }^{101}$ Exceto a quitação de crédito penhorado (cf. art. $\left.672, \S 3^{\circ}, \mathrm{CPC}\right)$, já analisada acima.
} 
De toda forma, registre-se que não haveria necessidade de prever essas três situações, pois a primeira equivale à alienação de bem do patrimônio do devedor e as duas últimas já possuíam existência autônoma em relação ao sistema do CPC, antes mesmo de o código de 1939 prever esse dispositivo com remissão genérica. Além disso, essas duas últimas hipóteses fogem à fisionomia característica da fraude de execução, pois prevêem a sua configuração antes mesmo da pendência de qualquer ação.

Dada a heterogeneidade dessas três situações, para evitar constantes ressalvas e repetições, a análise feita nesta tese terá por foco as hipóteses dos incisos I e II do artigo 593 do CPC. Registre-se apenas que, em relação à relevância do elemento subjetivo para a configuração dos casos inseridos no inciso III do artigo 593 do CPC, para o artigo 129 da Lei n. ${ }^{\circ}$ 11.101/2005 é absolutamente irrelevante a boa ou má-fé do terceiro, por opção expressa feita pelo legislador. Nas hipóteses do artigo 672, $\S 3^{\circ}$, do CPC e do artigo 185 do CTN, é aplicável o mesmo raciocínio feito para o inciso II do artigo 593 do CPC, mas em relação à última, em vez do ajuizamento da ação, o marco inicial da fraude de execução será a inscrição do crédito na dívida ativa. 


\section{3- O ESTADO DA QUESTÃo: O ELEMENTO SUBJETIVO COMO REQUISITO PARA CONFIGURAÇÃO DA FRAUDE DE EXECUÇÃO E SUA FEIÇÃO CONFORME O ENTENDIMENTO DOMINANTE}

\section{1- Identificação do entendimento dominante}

Conforme visto acima, o entendimento atualmente dominante sustenta que o elemento subjetivo na fraude de execução seria a má-fé, tanto do devedor quanto do terceiro, sendo tal má-fé decorrente da ciência da ação pendente, seja a fundada em direito real (art. 593, I, CPC), seja a que possa reduzir do devedor à insolvência (art. 593, II, CPC).

Sustenta, ainda, que a relevância desse elemento subjetivo seria total, de modo que, além dos requisitos previstos nos artigos 592, V, e 593 do CPC, somente estaria configurada a fraude de execução se estivessem presentes (i) a ciência do devedor da pendência da ação, ou porque já houve a citação, ou porque ficou provada por outro modo; e (ii) a ciência do terceiro da pendência da ação, ou porque há notícia dela em registro público, ou porque ficou provada por algum outro meio, sendo o ônus da prova desses dois fatos exclusivo do credor.

Com o intuito de melhor identificar esse entendimento dominante para adiante confrontá-lo com nossa hipótese, passamos a explorar os principais argumentos em que se sustenta.

Inicialmente, vamos analisar a má-fé do devedor decorrente de sua ciência da ação. Para sustentar esse requisito, que se exige indistintamente para as hipóteses dos incisos I e II do artigo 593, CPC, apresentam-se dois argumentos.

O primeiro consiste no fato de que a ação ainda não estaria "pendente" a não ser que o devedor já tivesse sido validamente citado. É a lição de SÁLVIO DE FIGUEIREDO TEIXEIRA: "somente a citação válida surte os efeitos previstos do art. 219 do 
CPC. Antes da angularização da relação processual inocorre a fraude de execução, somente podendo cogitar-se, até então, da fraude contra credores." 102

O segundo argumento é no sentido da impossibilidade de haver vontade de o devedor fraudar a execução sem que ele tenha ciência do processo, o que só ocorre, em regra, com a citação.

Nesse sentido, afirma DinAMARCo que "essa fraude não tem absolutamente como se caracterizar antes que um processo haja sido instaurado (formado) mas não é exato dizer que a simples formação do processo pela propositura da demanda já crie sempre, por si mesma, o clima propício à fraude executiva. Em princípio, reputa-se momento inicial do processo, para o fim de caracterização da fraude executiva, aquele em que é feita a citação do demandado e não aquele em que o processo tem início (propositura da demanda); só então ele fica ciente da demanda proposta, não sendo razoável nem legítimo afirmar uma fraude da parte de quem ainda não tenha conhecimento da litispendência instaurada (poderá sim ocorrer fraude contra credores)... Mas essa razão cessa quando por algum modo o demandado já tiver conhecimento da pendência do processo, antes de ser citado; essa é uma questão de fato a ser apreciada caso a caso, sendo legítimo considerar até mais maliciosa a conduta daquele que se furta à citação com o objetivo de desfazer-se de bens ou onerá-los antes que esta se consuma." 103

\footnotetext{
${ }^{102}$ TEIXEIRA, Sálvio de Figueiredo. Fraude de execução, cit., p. 12. Ainda nessa linha: Araken de Assis: "consoante dispõem os artigos $263,2^{a}$ parte, e 219, do CPC, a litispendência decorre da citação válida. E isso, porque se destina a produzir o efeito da 'pendência' da lide perante o réu, não se relacionando, absolutamente, à constituição da relação processual linear entre o autor e o Estado (art. 263, $1^{\mathrm{a}}$ parte). É a partir da data em que ocorreu a citação válida do réu, portanto, que se passará a cogitar da fraude de execução." (ASSIS, Araken de. Comentários ao Código de Processo Civil, cit., p. 246).

Também esse o entendimento adotado pelo Superior Tribunal de Justiça, inclusive por sua Corte Especial: "para que se considere a alienação em fraude de execução não é suficiente o ajuizamento da ação. Há, para tanto, necessidade da citação válida do executado para demanda com possibilidade de convertê-lo à insolvência" (STJ, 4 ${ }^{\mathrm{a}}$ T., REsp. 2.573-RS, rel. Min. Fontes de Alencar, j. 14.05.90); "não é possível a declaração de fraude de execução sem a existência de demanda anterior com citação válida" (STJ, Corte Especial, EREsp. 259.890/SP, rel. Min. José Delgado, j. 02.06.04); "a alienação ou oneração de bens, antes da citação válida, não configura fraude de execução" (STJ, 4ª T., AgRg no REsp 316.905/SP, rel. Min. Luis Felipe Salomão, j. 20.11.08).

${ }^{103}$ DINAMARCO, Cândido Rangel. As fraudes do devedor, cit., v. 4, p. 443. Também nesse mesmo sentido, Carlos Alberto Carmona: "o réu só pode cometer ato que objetive fraudar o processo se estiver ciente da existência desse mesmo processo, o que ocorrerá com a citação.(...) Se o credor puder provar que antes mesmo da citação o devedor teve conhecimento da existência da demanda, alienando seus bens para impedir a excussão patrimonial, não parece despropositado abrir exceção à regra para abarcar o ato na fraude de execução" (in MARCATO, Antonio Carlos (Coord.). Código de Processo Civil interpretado, cit., p. 1.951), Paulo Henrique dos Santos Lucon: "antes da penhora, os requisitos caracterizadores da fraude de execução podem ser assim elencados: a) ato jurídico que importe a alienação ou oneração de bens; b) capaz de reduzir o devedor à insolvência; c) após a sua citação em processo cognitivo ou executivo ou, ainda, o seu conhecimento inequívoco da existência da demanda por qualquer meio possível de ser provado
} 
Já no tocante à exigência da má-fé do terceiro, configurada por sua ciência da demanda pendente, diferem os argumentos quanto às hipóteses dos incisos I e II do artigo 593 do CPC.

No primeiro caso, das ações fundadas em direito real, argumenta-se que a presente Lei de Registros Públicos exige - como antes exigia o Decreto n. ${ }^{\circ}$ 4.857/1939 - o registro da citação. Nesse sentido: ALCIDES DE MENDONÇA LIMA: "não basta, porém, a simples ação em juízo, já proposta, isto é, com a citação do réu (art. 263, $2^{a}$ parte, deste Código), para que a 'fraude de execução' se caracterize de modo absoluto, envolvendo o terceiro adquirente. É indispensável a formalidade da inscrição da citação do réu em tais ações no Registro de Imóveis, referentes aos bens (Decreto n. ${ }^{\circ}$ 4.857, de 19.11.1939, art. 178, letra $a$, VI e VII; e art. 279 a 281, que regulou os Registros Públicos; e, presentemente, desde $1^{\circ} .1 .1976$, a Lei n. ${ }^{\circ} 6.015$, de 31.12.1973, art. 168, I, letra $t$, e art. 169). (...) Cabe ao exequente, sem a inscrição, o "ônus de provar que o adquirente tinha conhecimento de que sobre os bens está sendo movido litígio fundado em direito real." ${ }^{104}$

No segundo caso, referente às ações que podem reduzir o devedor à insolvência, originalmente, o argumento também se baseia no registro - hoje averbação da penhora, também prevista na Lei de Registros Públicos, mais precisamente em seus artigos 167, I, 5, 169 e 240. No entanto, após as reformas processuais implementadas pelas Leis $\mathrm{n}^{\text {os }} 8.953$, de 14 de dezembro de 1994 , 10.444, de 7 de maio de 2002, e 11.382, de 6 de dezembro de 2006, o entendimento dominante também passou a fundamentar-se no $\S 4^{\circ}$ do artigo 659 e no artigo 615-A, que foram então introduzidos no CPC.

Nesse sentido, SÁlvio de FIgUeIREdo TeIXEIRA: "inexistindo registro da citação (hipóteses dos ns. I e II do art. 593 do CPC) ou do gravame judicial, ao credor cabe

judicialmente (p. ex. notificação)" (LUCON, Paulo Henrique dos Santos. Fraude à execução, responsabilidade processual civil e registro da penhora, cit., p. 132) e Ricardo Chemale Selistre Peña (Fraude à execução, cit., p. 73).

${ }^{104}$ LIMA, Alcides de Mendonça. Comentários ao Código de Processo Civil, cit., v. 6, t. 2, p. 567-568, referindo-se à numeração antiga da Lei n. ${ }^{\circ}$ 6.015/1973. Também nesse sentido, Teori Albino Zavascki: "na hipótese do inciso I, há que se ter como relativa, e não absoluta, a presunção de que o terceiro, participante do negócio, conhecia a litigiosidade instalada sobre o bem. Em se tratando, porém, de bem imóvel, o registro da citação no ofício imobiliário, previsto no artigo 167, I, 21, da Lei 6.015, de 31.12.1973, é 'prova presumida irrefragável de conhecimento das condições legais de fraude por parte de terceiro." Se o registro não tiver sido lavrado, nem por isso se descarta a fraude, e a questão se resume então em definir a quem cabe o ônus de provar a ciência, pelo terceiro, da pendência da ação." (ZAVASCKI, Teori Albino. Comentários ao Código de Processo Civil, cit., v. 8, p. 269-270). 
o ônus de provar a ciência, pelo terceiro, adquirente ou beneficiário, da existência da demanda ou do gravame."105

Também nesse sentido, a já citada súmula 375, editada em 18 de março de 2009 pelo Superior Tribunal de Justiça: “o reconhecimento da fraude à execução depende do registro da penhora do bem alienado ou da prova de má-fé do terceiro adquirente." Tal súmula, como sói acontecer, deve representar a consolidação da jurisprudência firme daquele tribunal. ${ }^{106}$

No entanto, tínhamos ciência de que, nos anos de 2007 e 2008, havia pelo menos três acórdãos do próprio Superior Tribunal de Justiça em sentido diverso do fixado na súmula $375,{ }^{107}$ indicando a existência de certa oscilação na jurisprudência. ${ }^{108}$

\footnotetext{
${ }^{105}$ TEIXEIRA, Sálvio de Figueiredo. Fraude de execução, cit., p. 12. Também nessa linha: Paulo Henrique dos Santos Lucon: "a falta de registro não impede a alegação de fraude de execução, mas tem conseqüência direta sobre o ônus da prova. Isso significa, em síntese, que o exeqüente, sem o registro da penhora, tem o encargo de provar a má-fé do adquirente como imperativo de seu interesse. Ou seja, competirá ao exequiente provar que o adquirente tinha conhecimento de que estava sendo movida em face do alienante demanda capaz de provocar um substancial desequilíbrio patrimonial de tal modo que ficaria insolvente." (LUCON, Paulo Henrique dos Santos. Fraude à execução, responsabilidade processual civil e registro da penhora, cit., p. 139); Cledi de Fátima Manica Moscon: "é de se concluir pela necessidade da citação o demandado como marco temporal inicial a configurar, em fraude de execução, os atos de disposição praticados pelo devedor. Entretanto o critério não deve ser rígido, comportanto prova inequívoca da ciência do réu da demanda em curso, mesmo antes de citado (...) a scientia fraudis há de ser exigida para que o terceiro adquirente sofra os efeitos da constrição dos bens adquiridos" (MOSCON, Cledi de Fátima Manica. Fraude de execução judicial, cit., p. 104 e 118).

${ }^{106}$ Essa a lição de Barbosa Moreira: "a palavra 'súmula' sempre se empregou - em perfeita consonância com a etimologia e os dicionários - para designar o conjunto das proposições em que se resume a jurisprudência firme de cada tribunal" (BARBOSA MOREIRA, José Carlos. A Emenda Constitucional 45 e o processo. In:__. Temas de direito processual: nona série. São Paulo: Saraiva, 2007. p. 27).

${ }^{107}$ Cf. os seguintes trechos dos acórdãos que, ao contrário da Súmula 375, entendem que cabe ao terceiro o ônus de provar sua boa-fé: "cabe ao comprador do imóvel provar que desconhece a existência da ação em nome do proprietário do imóvel, não apenas porque o art. $1^{\circ}$, da Lei n. ${ }^{\circ}$ 7.433/85 exige a apresentação das certidões dos feitos ajuizados em nome do vendedor para lavratura da escritura pública de alienação de imóveis, mas, sobretudo, porque só se pode considerar, objetivamente, de boa-fé, o comprador que toma mínimas cautelas para a segurança jurídica da sua aquisição" (STJ, 3 ${ }^{a}$ T., REsp 655.000/SP, rel. Min. Nancy Andrighi, j. 23.08.07); "o inciso II, do art. 593, do CPC, estabelece uma presunção relativa da fraude, que beneficia o autor ou exequiente, razão pela qual é da parte contrária o ônus da prova da inocorrência dos pressupostos da fraude de execução" (STJ, 3a T., REsp 618.625/SC, rel. Min. Nancy Andrighi, j. 19.02.08); e "a presunção relativa de fraude à execução pode ser invertida pelo adquirente se demonstrar que agiu com boa-fé na aquisição do bem, apresentando as certidões de tributos federais e aquelas pertinentes ao local onde registrado o bem e onde tinha residência o alienante ao tempo da alienação, em analogia às certidões exigidas pela Lei n. 7.433/85, e demonstrando que, mesmo de posse de tais certidões, não lhe era possível ter conhecimento da existência da execução físcal" (STJ, $1^{\mathrm{a}}$ T., REsp. 751.481/RS, rel. Min. Mauro Campbell Marques, j. 25.11.08).

${ }^{108}$ Tal fato foi comentado pela doutrina especializada: "a nova orientação da $3^{\text {a }}$ Turma do STJ, a respeito do ônus da prova da (in)ocorrência da fraude de execução é a de que cabe ao terceiro-adquirente o ônus de provar, nos embargos de terceiro, que, mesmo constando da escritura de transferência de propriedade do imóvel a indicação da apresentação dos documentos comprobatórios dos feitos ajuizados em nome do proprietário do imóvel, que não lhe foi possível tomar conhecimento desse fato. (...) Essa mudança de entendimento é salutar, porquanto a jurisprudência prevalente até então tornava extremamente difícil para o credor a prova da fraude à execução, o que acabava por privilegiá-la. Espera-se que, agora, a $4^{\mathrm{a}}$ Turma do
} 
A existência desses acórdãos, somada à constatação de heterogeneidade entre os vinte e um precedentes que embasaram a edição da súmula $375,{ }^{109}$ levou-nos a empreender análise jurisprudencial mais ampla, não só para aferir que o entendimento dominante efetivamente era o da súmula 375 - conclusão que era esperada e que, de fato, se confirmou -, mas também para verificar se existiam linhas determinantes na evolução do entendimento do Superior Tribunal de Justiça sobre o tema objeto desta tese, principalmente em razão das reiteradas alterações na legislação infraconstitucional. ${ }^{110}$

Com base na análise empreendida, pode-se concluir que, para o entendimento dominante, o elemento subjetivo relevante para a configuração da fraude de execução é a má-fé tanto do devedor quanto do terceiro, sendo que essa má-fé decorre da ciência da ação pendente. ${ }^{111} \mathrm{E}$, ainda, que tal elemento subjetivo constitui verdadeiro requisito para a configuração da fraude de execução, somando-se aos previstos nos artigos 592 , V, e 593 do CPC. ${ }^{112}$

STJ também siga essa orientação, a fim de que se unifique esse entendimento no âmbito da $2^{\text {a }}$ Seção." (MOREIRA, Fernando Mil Homens. Rápida exposição sobre a nova orientação da $3^{\text {a }}$ turma do STJ a respeito do ônus da prova da (in)ocorrência de fraude à execução. Revista de Processo, São Paulo, v. 33, n. 161, p. 242, jul. 2008).

${ }^{109}$ De fato, entre esses 21 precedentes, encontramos (i) hipóteses distintas de fraude de execução: 16 acórdãos tratam do inc. II do art. 593, CPC, enquanto os outros 5 tratam de execução fiscal prevista no inc. III do art. 593, CPC c/c art. 185, CTN; (ii) bases fáticas distintas: 14 acórdãos tratam de casos em que a alienação ocorrera antes da penhora, contra apenas 7 em que a alienação se deu após a constrição; (iii) diversidade de pessoas envolvidas: 11 acórdãos tratavam de casos envolvendo terceiros mediatos, contra 10 envolvendo terceiros imediatos. O relatório da análise que nos permitiu verificar essas heterogeneidades encontra-se no Apêndice 1 desta tese.

${ }^{110}$ Para maior homogeneidade, nossa pesquisa teve por base apenas acórdãos que versassem sobre a hipótese do inciso II do artigo 593 do CPC, julgados pela Corte Especial, $2^{\mathrm{a}}$ Seção e pelas $3^{\mathrm{a}}$ e $4^{\mathrm{a}}$ Turmas do Superior Tribunal de Justiça, buscando, em razão da competência desses órgãos, eliminar ao máximo casos referentes às hipóteses do inciso III, notadamente casos de execução fiscal e de falência ou recuperação judicial, pois envolvem não apenas situações distintas, mas também a aplicação de normas e princípios diversos. Pelos critérios utilizados, obteve-se base de dados formada por mais de 200 acórdãos, que foram analisados conforme o relatório que está no Apêndice 2 desta tese e cujos dados serão utilizados nos próximos capítulos.

${ }^{111}$ Confirmou-se, portanto, a percepção de Dinamarco no sentido de que "ao falar em má-fé, aquela Súmula está aludindo simplesmente ao conhecimento, pelo adquirente da pendência processual - quer seja ela cognitiva ou executiva; e que o registro da penhora serve somente para dispensa dessa prova" (DINAMARCO, Cândido Rangel. As fraudes do devedor, cit., p. 446).

${ }^{112}$ Também se confirmou, portanto, a constatação de diversos doutrinadores, entre os quais Luiz Rodrigues Wambier e Eduardo Talamini ao afirmarem que "há clara orientação na jurisprudência (especialmente do Superior Tribunal de Justiça) no sentido de reputar imprescidível a ciência, pelo adquirente, da demanda fundada em direito real ou capaz de reduzir o devedor à insolvência. Ainda de acordo com esse entendimento, quando levada a registro público a pendência da demanda (exemplo: Lei n. ${ }^{\circ}$ 6.015/73, art. 167, I, 21), estabelece-se presunção absoluta de sua ciência pelo adquirente. Caso contrário, é ônus do credor provar que o adquirente sabia da existência da ação." (WAMBIER, Luiz Rodrigues; TALAMINI, Eduardo. Curso avançado de processo civil. 10a ed. São Paulo: Ed. Revista dos Tribunais, 2009. v. 2, p. 137). 


\title{
3.2- Críticas ao entendimento dominante
}

A primeira crítica ao entendimento dominante é no sentido de que torna o elemento subjetivo na fraude de execução até mesmo mais relevante do que na fraude contra credores, uma vez que os artigos 158 e 159 do CC - tal como os artigos 106 e 107 do código civil revogado - apenas exigem a existência de razão para que o terceiro soubesse da insolvência do devedor e isso somente nas alienações onerosas:

\begin{abstract}
"Art. 158. Os negócios de transmissão gratuita de bens ou remissão de dívida, se os praticar o devedor já insolvente, ou por eles reduzido à insolvência, ainda quando o ignore, poderão ser anulados pelos credores quirografários, como lesivos dos seus direitos.

$\S 1^{\circ}$ Igual direito assiste aos credores cuja garantia se tornar insuficiente.

$\S 2^{\circ}$ Só os credores que já o eram ao tempo daqueles atos podem pleitear a anulação deles.
\end{abstract}

Art. 159. Serão igualmente anuláveis os contratos onerosos do devedor insolvente, quando a insolvência for notória ou houver motivo para ser conhecida do outro contratante."

Embora diversos autores sustentem que, para a configuração da fraude contra credores, haveria necessidade de se demonstrar a presença do consilium fraudis, consistente na intenção do devedor de fraudar o recebimento do crédito ou, para alguns, consistente, até mesmo, na figura do conluio fraudulento (concilium fraudis) ${ }^{113}$ entre devedor e terceiro, o entendimento mais consentâneo com o direito positivo é no sentido de que, para a configuração da fraude contra credores nas alienações onerosas, basta a scientia fraudis ou, nos termos do artigo 159 do Código Civil, a notoriedade da insolvência do devedor ou a existência de motivo para esta ser conhecida do outro contratante. Já nas alienações a título gratuito, nem isso é necessário, sendo que o artigo 158 do Código Civil dispensa totalmente o elemento subjetivo nesse caso. ${ }^{114}$

\footnotetext{
${ }^{113}$ Sobre a diferença entre as figuras, cf. Luiz Carlos de Azevedo: "a expressão consilium significa propósito, intuito (...). Não se trata de concilium, conluio, acordo, mas de consilium; com 's' e não com 'c'." (AZEVEDO, Luiz Carlos de. Fraude contra credores. Revista da Escola Paulista da Magistratura, São Paulo, v. 3, n. 1, p. 61, jan./jun. 2002).

${ }^{114}$ Nesse sentido, os autorizados entendimentos de Clóvis Bevilacqua: "as liberalidades (art. 106) annullam-se independentemente de má-fé, pela simples razão de tornarem o devedor insolvente, ou serem praticadas em estado de insolvência. Para a anullabilidade dos contractos onerosos, não basta a insolvência do devedor; é necessário mais que esse estado seja conhecido da outra parte contractante, por ser notorio, ou porque tenha esta motivo de o conhecer." (BEVILÁQUA, Clóvis. Código Civil dos Estados Unidos do Brasil, cit., p. 361) e Pontes de Miranda: "se bem que ao instituto se chame 'fraude contra credores' (Seção V, Da fraude
} 
Outra crítica que poderíamos dirigir ao entendimento dominante é que a exigência da efetiva ciência como caracterizadora da má-fé e a atribuição do ônus de sua prova exclusivamente ao credor tornam a configuração da fraude de execução particularmente difícil, principalmente quando sequer o registro é possível, como nos casos em que ainda não há penhora. ${ }^{115}$

Tal dificuldade é tão grande que chega até mesmo a praticamente anular a hipótese do inciso II do artigo 593 do CPC caso não haja penhora registrada, conforme se extrai do voto vencido do Ministro Ari Pargendler, nos Embargos de Divergência em Recurso Especial n. ${ }^{\circ}$ 509.827/SP, um dos precedentes que deram origem à súmula 375 do Superior Tribunal de Justiça: "a tese jurídica adotada no acórdão embargado elimina uma das hipóteses da fraude à execução previstas no art. 593, II do Código de Processo Civil, aquela ocorrida durante o processo de conhecimento. (...) Nessa etapa, não há penhora, nem pode haver, conseqüentemente, registro dela." ${ }^{116}$

A observação não é desprovida de sentido. Na pesquisa jurisprudencial realizada, constatamos que, dos 137 acórdãos identificados como pertencentes ao

contra credores), nenhuma vez se alude à intenção, ao consilium fraudis, que, junto ao eventus damni, o fato de causar dano, eram pressupostos da ação justinianéia. (...) não vemos como se possa encontrar tal elemento, se não nos deixarmos impressionar com o sentido moderno de fraude (...) uma vez que o direito brasileiro, nos arts. 106 e 107, abstraiu do consilium fraudis, fraude há, se há insolvência, eventus damni, e, nas espécies do art. 107, scientia fraudis. (...) Diz o art. 106: 'os atos de transmissão gratuita de bens, ou demissão de dívida, quando os pratique o devedor já insolvente, ou por eles reduzido à insolvência, poderão ser anulados pelos credores quirografários como lesivos dos seus direitos'. Aí, evidentemente, se abstrai do consilium fraudis, no sentido exato de intenção, e da scientia fraudis, por parte daquele a quem se transmite, gratuitamente, ou a quem se remete a divida. No art. 107, não: se é certo que se continua a abstrair do consilium fraudis, exige-se a notoriedade do fato da insolvência (= ciência por todos), ou, pelo menos, do outro figurante." E, finalmente, conclui: "no Código Civil, arts. 106-113, não se aludiu ao consilium fraudis." (MIRANDA, Francisco Cavalcanti Pontes de. Tratado de direito privado, cit., t. 4, p. 431-435 e 458) e, já na vigência do Código Civil atual, perfilham esse mesmo entendimento Álvaro Villaça Azevedo (Código Civil comentado. São Paulo: Atlas, 2003. v. 2, p. 247-253) e Humberto Theodoro Júnior, afirmando esse último, ao comentar o artigo 159, que "o Código, como se vê, não exigiu, nem mesmo no caso dos negócios onerosos, a comprovação do consilium fraudis (intenção de lesar credores) da parte do devedor alienante. Presumiu-o, portanto. Mas, do lado do terceiro adquirente, impôs a demonstração de sua scientia fraudis, necessária à configuração da má-fé, sem a qual o ato dispositivo do devedor não será revogável." (THEODORO JÚNIOR, Humberto. Comentários ao novo Código Civil. Rio de Janeiro: Forense, 2003, v. 3, t. 1, p. 347).

${ }^{115}$ Nesse sentido, cf. ASSIS, Carlos Augusto de. Fraude à execução e boa-fé do adquirente. Genesis: Revista de direito processual civil. Curitiba, v. 5, n. 16, p. 234, abr./jun. 2000.

${ }^{116}$ STJ, $2{ }^{a}$ Seção, EDREsp. 509.827/SP, Rel. p/ acórdão Min. Carlos Alberto Menezes Direito, j. 25.04.07, votaram vencidos, além do Min. Ari Pargendler (relator original), a Min. Nancy Andrighi e o Min. Humberto Gomes de Barros. Acompanharam o relator os Mins. Fernando Gonçalves, Aldir Passarinho Junior e Jorge Scartezzini. 
entendimento dominante, apenas 10 (ou seja, 7,29\%) reconheceram a fraude de execução. $^{117}$

Somente em casos em que a prova da má-fé era muito evidente, como em doações de pai para filho ou na existência de documentos ou depoimentos sobre a efetiva ciência do terceiro quanto à pendência da ação é que tal entendimento reconhece a fraude de execução. ${ }^{118}$

Não parece, portanto, que, o entendimento dominante ofereça critério adequado para se aferir a feição e a relevância que o elemento subjetivo deve ter para a configuração da fraude de execução. Não, ao menos, a ponto de permitir que o Estado cumpra seu dever de atribuir, por meio da atividade jurisdicional, o resultado mais próximo possível do que o credor teria com o cumprimento voluntário da obrigação pelo devedor. ${ }^{119}$

Conforme exposto no início desta tese, o que se propõe, a partir de agora, é verificar, na história do instituto, se sempre foram essas a feição e relevância atribuídas ao elemento subjetivo ou se seriam outras como as propostas em nossa hipótese e, nesse último caso, também verificar quais foram as razões para a alteração ocorrida.

\footnotetext{
${ }^{117}$ Cf. pesquisa por nós empreendida cujo relatório encontra-se no Apêndice 2 desta tese.

${ }^{118} \mathrm{Cf}$. relatório contante do Apêndice 2 desta tese.

${ }^{119}$ Conforme estabelece a célebre lição de Chiovenda, segundo a qual "o processo deve dar, quanto for possível, praticamente, a quem tenha um direito, tudo aquilo e exatamente aquilo que ele tenha direito de conseguir" (CHIOVENDA, Giuseppe. Instituições de direito processual civil. Trad. de Guimarães Menegale, notas de Enrico Tullio Liebman. São Paulo: Saraiva, 1965. v. 1, p. 46). Cf. também nesse sentido BARBOSA MOREIRA, José Carlos. Notas sobre a efetividade do processo. In: Temas de direito processual: terceira série. São Paulo: Saraiva, 1984. p. 28-29; LIEBMAN, Enrico Tullio. Processo de execução, cit., p. 2-3; e MESQUITA, José Ignacio Botelho de. Limites ao poder do juiz nas cautelares antecipatórias. In: 2007. v. 3, p. 211 . Teses, estudos e pareceres de processo civil. São Paulo: Ed. Revista dos Tribunais,
} 


\section{4- ANÁlise HiStórica da FRAUde DE EXECUÇÃo NO DIREITO BRASILEIRO: BUSCA DA ORIGEM DO PROBLEMA E RESGATE DA FEIÇÃO E DA RELEVÂNCIA ORIGINAIS DO ELEMENTO SUBJETIVO}

Antes de se partir em busca da feição e da relevância que o elemento subjetivo desempenhou ao longo da história da fraude de execução, convém, para efeito metodológico, justificar o corte temporal da análise realizada nesta tese.

Não se ignora que o combate a situações de frustração da atividade executiva tem sua origem remota no direito romano clássico, aproximadamente no século I a.C., com o surgimento dos institutos da restitutio in integrum ob fraudem e do interdictum fraudatorium, ${ }^{120}$ que tinham por objetivo evitar a frustração do procedimento da bonorum venditio, por meio de alienações que esvaziassem o patrimônio do devedor. ${ }^{121}$

Sabe-se, também, que a preocupação em evitar a frustração da atividade executiva prosseguiu durante a Idade Média e, na linha evolutiva do direito luso-brasileiro, foi objeto de normas específicas nas Ordenações Afonsinas, ${ }^{122}$ Manuelinas ${ }^{123}$ e Filipinas, dispondo essa última - similarmente às anteriores - que, se no curso de ação fundada em

\footnotetext{
${ }^{120}$ Previstos, respectivamente, nos seguintes fragmentos do Digesto: Ulp. 66, ad. ed., D. 42, 8, 1 pr. e Ulp. 73, ad. ed., D. 42, 8, $10 \mathrm{pr}$. Tais institutos constituem a origem remota tanto das formas de fraude de execução quanto de fraude contra credores. Há alguns autores que incluem entre esses primeiros meios de reação às fraudes do devedor também a ação pauliana (cf. NONATO, Orozimbo. Fraude contra credores. Rio de Janeiro: Jurídica Universitária, 1969. p. 24; CAHALI, Yussef Said. Fraudes contra credores, cit., p. 83; e, mais recentemente, SALAMACHA, José Eli. Fraude de execução: direitos do credor e do adquirente de boafé, cit., p. 122). No entanto, entre os estudiosos do tema, prevalece a interpretação de que a ação pauliana somente surgiu depois, provavelmente já no direito justinianeu, exatamente como fruto da fusão da restitutio in integrum ob fraudem e do interdictum fraudatorium (cf. MIRANDA, Francisco Cavalcanti Pontes de. Tratado de direito privado, cit., t. 4, p. 422; MOREIRA ALVES, José Carlos. Direito romano. Rio de Janeiro: Forense, 2001. v. 1, n. ${ }^{\circ}$ 130, p. 253 e AZEVEDO, Luiz Carlos de. Fraude contra credores, cit., p. 56).

${ }^{121}$ Nesse sentido, afirma Luiz da Cunha Gonçalves que "depois que, na Roma antiga, o processo Rutiliano introduziu, entre os meios executivos contra o devedor, a bonorum venditio, desde logo principiaram a surgir actos fraudulentos em prejuízo dos credores, desfazendo-se os devedores de seus bens, ou onerandoos, antes que fossem por aqueles apreendidos, embora por meio de contratos verdadeiros. Essas fraudes determinaram, como era de se esperar, a concessão aos credores, no edicto pretoriano, dos meios necessários a revogação daqueles." (GONÇALVES, Luiz da Cunha. Tratado de direito civil. Coimbra: Coimbra Ed., 1932, v. 5, p. 768) e Luiz Carlos de Azevedo complementa "como reação natural dos credores contra esse modo de proceder, ainda no Direito Clássico Romano, foram criados meios para evitar os prejuízos que dele podiam resultar: entre eles, o interdictum fraudatorium, dirigido ao terceiro adquirente, para obrigá-lo a restituir quanto recebera do devedor; ou a restitutio in integrum, que fazia retornar as coisas ao estado anterior ao da alienação." (AZEVEDO, Luiz Carlos de. Fraude contra credores, cit., p. 56).

${ }^{122}$ Cf. L. III, T. LXXXXI.

${ }^{123}$ Cf. L. III, T. LXXI.
} 
direito real ou pessoal para entrega de coisa certa, o devedor alienou a coisa objeto da ação, a execução poderia fazer-se sobre ela, sem a necessidade de instauração de outro processo, se estivesse em poder de quem, no momento da aquisição, sabia ou tinha "justa razão" para saber que a coisa era litigiosa. ${ }^{124}$

No entanto, apesar de tais períodos serem de grande interesse para o estudo do desenvolvimento da fraude de execução, optou-se, nesta tese, por iniciar a análise histórica a partir de 1850, quando, em decorrência do disposto no artigo 27 do Título Único do Código Comercial, foi promulgado o Regulamento 737, dispondo sobre o processo comercial e separando-o do processo civil, que permanecia regulado pelas Ordenações Filipinas e leis extravagantes.

A opção justifica-se, pois foi só nesse diploma legislativo que o instituto da fraude de execução assumiu contornos semelhantes aos que tem na legislação atual e recebeu o nomen iuris pelo qual passou a ser conhecido na ciência processual. ${ }^{125}$ Além

124"15. E quando a sentença, de que se requer execução fôr per que algum seja condenado per aução real, ou pessoal, que entregue cousa certa ao vencedor, assinar-lhe-ha o Juiz da execução termo de dez dias, a que a entregue, se hi fôr achado. (...)

"16. E se esse condenado maliciosamente deixou de possuir a cousa julgada, por se não fazer em ella execução, depois da lide com ele contestada em diante, far-se-ha execução em ella, se achada for em poder daquelle, em que foi alheada, sem ser com elle outro processo ordenado, se foi sabedor, como a dita cousa era litigiosa ao tempo, que foi trespassada a nelle, ou se teve justa razão de o saber." (L. III, T. LXXXVI, especificamente aqui os trechos iniciais de seus $\S \S 15$ e 16, in ALMEIDA, Cândido Mendes de. Código Philipino ou Ordenações e Leis do Reino de Portugal, cit., Livro III, p. 702).

As normas desses parágrafos eram completadas pelas existentes no Título $\mathrm{X}$ do Livro IV, "Das vendas e alheiações que se fazem de coisas litigiosas", de cujos $\S \S 4$ e 9 se extrai a ideia de que, mesmo se o terceiro não tivesse razão para saber que o bem era litigoso, este seria alcançado pela execução, sendo apenas relevante a impossibilidade de seu conhecimento para isentá-lo das penas pecuniárias previstas nos $\S \S 3 \mathrm{e}$ 7, primeira parte, desse título e outorgar-lhe o direito à indenização previsto nos $\S \S 4$ e 7 , parte final, permitindo-se que ele fosse ouvido sumariamente na própria execução para provar que não tinha razão para saber que o bem era litigioso:

"4. E no caso onde o comprador não soube, que a cousa comprada era litigiosa, a venda será em todo caso nenhuma, e o comprador cobrará do vendedor o preço que lhe deu por ella, e mais a terça parte delle pelo engano que lhe fez. E o vendedor pagará a Nós outro tanto, quanto foi o preço principal, porque a vendeo."

"9. E se depois de feita a venda, escaimbo, ou doação, o autor houver sentença contra o réo, que emalheou a cousa litigiosa, per essa mesma sentença, seja feita a execução contra a pessoa, a quem foi vendida, escaimbada, ou doada, em cujo poder a cousa for achada, sem mais ser chamado, nem citado, se foi sabedor do litigio ao tempo, que a houve, ou teve razão de o saber, como se disse no Livro terceiro, no Título 86: Das execuções que se fazem geralmente, no paragrapho 16: E se esse condenado. E não sendo delle sabedor, nem tendo razão de o saber, será citado para a execução, e ouvido com direito summariamente, sabida somente a verdade, sem outro processo." (in ALMEIDA, Cândido Mendes de. Código Philipino ou Ordenações e Leis do Reino de Portugal. Rio de Janeiro: Typ. do Instituto Philomathico, 1870. Livro IV, p. 788-789).

Nota-se, portanto, que, no regime das Ordenações Filipinas, não se permitia, de forma alguma, que a atividade jurisdicional fosse frustrada pela alienação do bem litigioso.

${ }^{125} \mathrm{Cf}$., por todos, José Sebastião de Oliveira: "apesar de ter sido nas Ordenações do Reino que afloraram os dispositivos que deram margem ao surgimento do instituto da fraude à execução, este, porém, somente surgiu entre nós, pela primeira vez, como norma processual pátria consolidada, no Regulamento 737". (Fraude à execução, cit., p. 47). 
disso, como será visto nos itens seguintes, foi somente a partir do confronto das normas do Regulamento 737 com a disciplina das Ordenações que se abriu o campo para indagação sobre a relevância do elemento subjetivo na configuração da fraude de execução.

De modo diverso das análises históricas normalmente encontradas nas monografias que tratam da fraude de execução, em que os dispositivos relativos ao instituto são analisados isoladamente, preferiu-se, nesta tese, apresentar a análise dividida por períodos - ao todo em número de quatro -, dada a coexistência de mais de uma norma processual sobre a matéria em algumas épocas. ${ }^{126}$

Da mesma forma, preferiu-se a divisão por períodos para permitir a análise conjunta de outras normas - em especial da legislação relativa aos registros públicos - que exerceram grande influência na disciplina da fraude de execução, sobretudo no tocante à relevância atribuída ao elemento subjetivo para sua configuração. ${ }^{127}$

Para auxiliar a análise, por vezes complexa, desse conjunto de normas, apresentamos, na Figura 1 do Apêndice 3 desta tese, um esquema gráfico, em forma de linha do tempo, da sequência evolutiva tanto da legislação aplicável processual, quanto de outras leis relevantes à matéria objeto desta tese.

\section{1- Primeiro período (1850-1890): surgimento e consolidação das hipóteses da fraude de execução nas leis do processo civil e do processo comercial e sua relação com as normas do registro imobiliário}

A fraude de execução foi prevista pela primeira vez no Regulamento 737, de 25 de novembro de 1850, que a disciplinava em sua Segunda Parte, Título I, Capítulo II, intitulado "do juiz e das partes competentes para a execução". ${ }^{128} \mathrm{O}$ artigo $492^{\circ}$ desse regulamento previa, entre outros casos, que a execução poderia se voltar contra o terceiro adquirente de bens alienados, segurados ou hipotecados em fraude de execução $\left(\S 6^{\circ}\right)$ e o

\footnotetext{
${ }^{126}$ Como durante os períodos em que a legislação processual estava bipartida em relação às causas cíveis e comerciais - primeiro período - ou federais e etaduais - segundo período.

${ }^{127}$ Não obstante sejam analisados os dispositivos das leis relativas aos registros públicos, o fio condutor da análise histórica é a evolução dos dispositivos que tratam da fraude de execução na legislação processual.

${ }^{128}$ Conforme já analisado no item 2.2, a localização das normas relativas à fraude de execução em capítulo relativo às partes da execução decorre da inexistência de clareza na diferença entre débito e responsabilidade.
} 
artigo $494^{\circ}$ especificava quais eram as circunstâncias em que a alienação ou a instituição de seguro ou hipoteca seriam consideradas realizadas em fraude de execução:

“Art. 492. ${ }^{\circ}$ É competente a execução contra: (...)

$\S 6 .^{\circ} \mathrm{O}$ comprador ou possuidor de bens hypothecados, segurados, ou alienados em fraude de execução (art. 494..$^{\circ}$; e em geral contra todos que recebem causa do vencido, como o comprador da herança; (...)"

"Art. 494. ${ }^{\circ}$ Consideram-se alienados em fraude de execução os bens do executado:

$\S 1 .^{\circ}$ Quando são litigiosos, ou sobre eles pende demanda;

$\S 2 .^{\circ}$ Quando a alienação é feita depois da penhora, ou proximamente a ella;

$\S 3 .^{\circ}$ Quando o possuidor dos bens tinha razão para saber que pendia demanda, e outros bens não tinha o executado por onde pudesse pagar." 129

Relata LAFAYETTE que, ao disciplinar os casos de fraude de execução em seu artigo $494^{\circ}$, o Regulamento 737 positivou o entendimento dos praxistas e tribunais antigos, segundo o qual a possibilidade de a execução alcançar bens em poder de terceiro deveria ser ampliada para além do caso previsto no $§ 16$ do Título 86 do Livro III das Ordenações Filipinas (“alienação de coisa certa que o réu é condenado a entregar”), abrangendo também alienações de bens realizadas no curso de ações que condenassem o devedor a "pagar cousa de quantidade, como dinheiro". ${ }^{130}$

De fato, conjugando e alargando os limites das disposições desse $\S 16$; do $§ 1$ do mesmo Título 86 - que tratava do desapossamento dos bens penhorados $-;^{131}$ do

${ }^{129}$ LEITÃO, Arthur de Freitas. Notas ao Processo Civil e Commercial-Regulamento 737, de 1850. 2. ed. São Paulo: C. Teixeira \& Cia, 1928. p. 130-131.

${ }^{130}$ Cf. PEREIRA, Lafayette Rodrigues. Direito das coisas, cit., v. 2, p. 176.

No regime das Ordenações Filipinas (Livro III, T. LXXXVI, § 13), as alienações no curso de ações desse tipo somente tinham como consequência a prisão do devedor e não a possibilidade de a execução alcançar, em patrimônio alheio, os bens que ele havia alienado para frustrar a execução:

"13. E se algum devedor, depois de ser condenado em alguma quantidade de dinheiro, pão, vinho, ou outra cousa que se costuma contar, pezar, ou medir, alhear seus bens em prejuizo do vencedor, por nelles se não fazer execução, seja preso e o não soltem até cumpridamente satisfazer o vencedor, sem poder fazer cessão." (ALMEIDA, Cândido Mendes de. Código Philipino ou Ordenações e Leis do Reino de Portugal, cit., Livro III, p. 701).

131"1. E sendo outrossi a condenação de dinheiro, ou de outra cousa, que se costume contar, pesar ou medir, de que já foi feita a liquidação, o condenado não será ouvido com embargos, e qualquer qualidade que sejam, até pagar, ou dar penhores livres e desembargados, que valham a quantia da condenação e custas da execução, e até serem os penhores realmente entregues às Justiças, que houverem de fazer a execução, ou à 
$\S 17$ também do Título 86 - que dispunha sobre os embargos de terceiro -; ${ }^{132}$ e do $§ 14$ do

Título 84 do Livro III - que tratava da instituição de hipoteca sobre os bens do vencido para impedir a execução na pendência de recurso de agravo para a Casa de Suplicação -, ${ }^{133}$

os praxistas sustentavam que, além do caso de alienação de bem litigioso, a execução também poderia se fazer diretamente sobre o bem alienado a terceiro, quando esse fosse objeto de penhora já realizada ou iminente, ou quando, ao tempo de sua alienação, esse terceiro soubesse que havia processo pendente em face do devedor e que este não possuía outros bens para satisfazer o crédito objeto desse processo. ${ }^{134}$

pessoa, a que as taes Justiças os mandarem entregar, de maneira que o condenado nem per si, nem per outrem fique per via alguma em posse dos penhores. E dando à penhora bens de raiz livres e desembargados, será desapossados delles, e serão entregues por auctoridade de Justiça a pessoa ou pessoas sem suspeita, seguras e abonadas, a que será mandado que os não entreguem, nem rendimento algum delles ao condenado.

E pagando o condenado, ou sendo feita a penhora, e a entrega pela dita maneira, poderá requerer sua justiça acerca dos embargos, com que vier, vindo dentro de seis dias depois da dita entrega ser feita." (ALMEIDA, Cândido Mendes de. Código Philipino ou Ordenações e Leis do Reino de Portugal, cit., Livro III, p. 701).

132"17. E vindo alguma pessoa a embargar alguma cousa, em que se peça a execução, assi movel, como de raiz, por dizer, que a cousa pertence a elle, e que não foi ouvido sobre ella, e que por tanto não deve ser entregue ao vencedor, ou allegar outro qualquer embargo a se dar a sentença execução, em tal caso mandamos que a execução se faça no condenado.

E sendo tal a razão do embargo, com que o terceiro embargante vem, que per Direito lhe deva ser recebida, o vencedor dará fiança à cousa de que se pede a execução, e lhe será entregue; e não a dando, será posta em poder de um terceiro, até finalmente se determinar sobre os embargos.

E vindo algum terceiro com embargos, dizendo ser possuidor dos bens, em que se faz a execução, se o condenado não der logo outros penhores livres e desembargados, será preso, até os dar." (in ALMEIDA, Cândido Mendes de. Código Philipino ou Ordenações e Leis do Reino de Portugal, cit., Livro III, p. 701).

133"Titulo LXXXIV. Dos aggravos das sentenças diffinitivas (...)

14. E pelas sentenças, de que assi fôr aggravado, tendo a parte aggravante pago o aggravo, e appresentado perante os Desembargadores em tempo devido, não se fará execução nos bens do condenado dentro em seis mezes continuos, contados do dia, em que fôr concedido o aggravo, e desembargado de quaesquer embargos, para se poder seguir: e isso se tanto durar o despacho na causa do aggravo.

Porem, tanto que a parte vencedor tiver a sentença passada pela Chamcellaria, posto que per ella se não haja de fazer execução, por durarem os ditos seis mezes, o condenado, que não tiver bens de raiz, dará fiança bastante à condenação, e não dando, será executada logo a sentença, sem esperar pelos seis mezes. E o que tiver bens de raiz, que valham o conteúdo na condenação, não os poderá alhear, durando a demanda, mas logo ficarão hypothecados por esse mesmo feito e per essa Ordenação para pagamento da condenação."(in ALMEIDA, Cândido Mendes de. Código Philipino ou Ordenações e Leis do Reino de Portugal, cit., Livro III, p. 696).

${ }^{134}$ Nesse sentido, Pereira e Sousa: "entende-se feita a alienação em fraude da Execução, quando é feita da cousa litigiosa na Causa de Acção real. Ord. L. 3, tit. 86, §. 16, L. 4, lit. 10, §. 9, ou quando é feita depois da penhora, ou immedialamente antes della, na Causa de Acção pessoal. Pegas Forens. c. 5, n. 120. Silv. ad Ord. L. 3, til. 86, §. 1, n. 33, ou quando o possuidor, para quem a cousa foi alienada, sabia que havia Causa pendente, e que o devedor não tinha mais bens por onde podesse pagar. Ord. L. 3, tit. 84, §. 14, tit. 86, §. 17. Portugal, de Bonat. L. 3, c. 38, n. 41. Silv. ad Ord. L. 3, tit. 86, §. 17, n. 73 et 75. Neste caso não é necessário usar da Acção Revocatoria, Moraes de Execut. L. 6, c. 7, n. 20. Silv. ad Ord. L. 6, tit. 86, n. 2, tit. 8, n. 73." (SOUZA, Joaquim José Caetano Pereira e. Primeiras linhas sobre o processo civil. Coimbra : Imprensa Litteraria, 1872. t. 3, p. 17, nota 777).

Também Lobão defendia esse entendimento e, ao comentar o $§ 14$ do Título 84 do Livro III, alargava seus limites dizendo que essa hipótese "comprehende o caso de ter o devedor poucos bens, ainda que não equivalentes à dívida" e que "neste caso para se executar essa sentença contra o terceiro comprador dos bens desse devedor não se attende, se elle tinha ou não sciencia da demanda, ou da insolvabilidade do devedor, mas só se elle, quando alienou os bens penhorados em poder de terceiro, tinha ou não bens 
Analisando o artigo $494^{\circ}$, acima transcrito, nota-se que, nos casos de seus $\S \S 1^{\circ}$ e $2^{\circ}$, não se exigia, para a configuração da fraude de execução, a necessidade de que o terceiro soubesse ou tivesse razão para saber que os bens eram litigiosos, que tinham sido penhorados ou que sua penhora estava próxima. ${ }^{135}$ Bastava a prova dos fatos, objetivos, de que, no momento da alienação, os bens já eram litigiosos, a penhora já havia sido feita ou era iminente para que a execução pudesse se voltar contra os bens que agora estavam em poder do adquirente. Apenas na hipótese do $\S 3^{\circ}$ é que o legislador previa tal requisito. ${ }^{136}$

Tendo em vista que o legislador dispensava o elemento subjetivo nas hipóteses dos $\S \S 1^{\mathrm{o}}$ e $2^{\mathrm{o}}$, interpretava-se que, nesses casos, a possibilidade de ciência do terceiro era presumida de forma absoluta. ${ }^{137}$

superabundantes, ou só equivalentes ou menos que equivalentes à dívida." $\mathrm{E}$, mais adiante, ao tratar dos embargos previstos no $\S 17$ acima transcrito, dizia "se o terceiro embargante pendente a lide sobre a divida e acção pessoal contra o executado, adquiria d'elle alguns bens com fraude de ambos para supplantar e fraudar o crédor, vendo ambos a futura condemnação, etc.; o terceiro que assim comprou ou adquiriu os bens, pendente a acção pessoal, e com tal fraude, não póde embargar a execução com pretexto do senhor e possuidor por tal titulo, Moraes, de Execut., L. 6, C. 7, n. 16, Peg., T. 1, For. 5, a n. 117, aonde muitas vezes o refere julgado; e isto sem ser necessario usar da acção ordinaria revocatoria contra o terceiro participante da fraude". Por fim, esclarecia que também se "procede a execução contra o terceiro que comprou a cousa depois de penhorada, ou comprasse scienter ou ignoranter, e sem fraude" (LOBÃO, Manuel de Almeida e Sousa. Tratado encyclopedico, pratico e critico sobre as execuções, cit., p. 49, $251 \mathrm{e}$ 253, $\S 50,305$ e 306, respectivamente).

${ }^{135}$ Esclarecia Arthur de Freitas Leitão que "a proximidade referida pela lei não é a do tempo em que a penhora deve realisar-se; é a do acto processual que colloca o devedor na imminencia da penhora. É fraudada a execução si o devedor aliena ou desvia bens, estando sob a ameaça de uma execução forçada; e tal situação existe para o devedor, quando das circumstancias occorrentes, resulta a intenção do credor de passar à referida execução dada a sua possibilidade juridica." (LEITÃO, Arthur de Freitas. Notas ao Processo Civil e Commercial - Regulamento 737, de 1850, cit., p. 131). Também nesse sentido, Philadelpho Azevedo: "essa proximidade não era a do tempo, mas a do acto processual que collocava o devedor na imminencia da penhora, isto é, quando houvesse execução apparelhada" (AZEVEDO, José Philadelpho de Barros e. Da fraude contra sentenças, cit., p. 19).

${ }^{136}$ Comentando esse $\S 3^{\circ}$, Philadelpho Azevedo afirmava que nele "se exigia prova do consilium fraudis, de que o adquirente deveria participar: 'quando o possuidor tinha razão para saber que pendia demanda e outros bens não tinha o executado por onde pudesse pagar.' Havia pelo menos a necessidade de prova, ainda que por presumpção, de que o adquirente tinha razão para conhecer a demanda; não se fazia violencia como nos casos anteriores, em que se presumia muitas vezes contra a verdade dos fatos." E, mais adiante, esclarecia que essa "prova por presunção" se dava "levando em conta as presumpções classicas de fraude, como o parentesco, a amisade, a capacidade economica do adquirente, a natureza de bens, a sua totalidade, a permanencia da posse, a falta de causa, o preço vil, a multiplicidade de actos para encobrir o embuste, a não execução da divida vencida etc." (AZEVEDO, José Philadelpho de Barros e. Da fraude contra sentenças, cit., p. 20-21 e 30).

${ }^{137}$ Cf. Philadelpho Azevedo: "o Regulamento 737 adotava uma theoria avançada, incluindo na revogação não só actos provadamente fraudulentos, como outros pelo simples resultado objectivo, independente de prova de fraude, que se presumia obrigatoriamente." (AZEVEDO, José Philadelpho de Barros e. Da fraude contra sentenças, cit., p. 26). Também nesse sentido, afirmava Arthur de Freitas Leitão, com base na jurisprudência da época, que "é presumida pela lei a fraude da alienação feita proximamente à penhora; e dispensada a prova, mesmo contra o adquirente" (LEITÃO, Arthur de Freitas. Notas ao Processo Civil e Commercial - Regulamento 737, de 1850, cit., p. 131-132). 
Tal interpretação procedia, pois, como modernamente observa BARBOSA MOREIRA, a presunção absoluta de determinado elemento pelo legislador equivale à dispensa desse elemento para se atingir o mesmo efeito que, noutra situação, a lei fazia depender de sua presença. Convém aprofundarmos um pouco essa ideia, dada a importância que terá posteriormente nesta tese, especialmente no tocante à questão da distribuição do ônus da prova do elemento subjetivo (cf. item 5.4, infra).

Explica BARBosa Moreira que a presunção absoluta consiste em "simples expediente técnico tendente a caracterizar determinadas hipóteses em que - ao contrário do que comumente ocorre - não é necessária a presença deste ou daquele elemento ou requisito, para que se haja de ter por existente ou válido um ato jurídico, ou ainda para que se produza tal ou qual efeito jurídico. Suponhamos que, em regra, a existência ou validade de certo ato, ou a produção de certo efeito, fique condicionada à concorrência dos elementos ou requisitos $a, b$ e $c$, mas que, nalguma hipótese particular, quiçá para facilitar a satisfação de interesse julgado merecedor de mais forte proteção, queira o legislador dispensar um deles $-c$, por exemplo. Em vez de dizer que bastam $a$ e $b$ para que exista ou valha o ato, ou para que se produza o efeito, diz que, sob aquelas circunstâncias peculiares, se presume (de modo absoluto) a presença de $c$. Esse é, ao nosso ver, do ponto-de-vista normativo, o verdadeiro esquema da presunção absoluta."138

Em se tratando de fraude de execução, os interesses maiores que tal presunção absoluta estava protegendo, eram a autoridade do Poder Judiciário e a efetividade do processo ou, no dizer de Philadelpho AzEvedo, "a moralidade e efficiencia da justiça". ${ }^{139}$ Buscava-se evitar que ao final do longo caminho processual, o credor, precisamente no momento da satisfação coativa de seu direito, a visse frustrada em razão de ter o devedor alienado o bem objeto da ação - bem litigioso - ou mesmo o bem que já estivesse constrito, ou na iminência de o estar, aguardando sua expropriação judicial - bem penhorado. Assim, poder-se-ia dizer que, nos casos dos $\S \S 1^{\circ}$ e $2^{\circ}$ do artigo $494^{\circ}$, o Regulamento 737 presumia de forma absoluta a possibilidade de conhecimento do terceiro em benefício da efetividade da própria atividade jurisdicional.

\footnotetext{
${ }^{138}$ BARBOSA MOREIRA, José Carlos. Presunções e prova. In: Temas de direito processual: primeira série. 2. ed. São Paulo: Saraiva, 1988. p. 63 - destaques no original. Voltando a essa mesma questão mais recentemente, o autor também reafirmou sua opinião em "Anotações sobre o título da prova do novo Código Civil. In: __. Temas de direito processual: nona série. São Paulo: Saraiva, 2007).

${ }^{139}$ AZEVEDO, José Philadelpho de Barros e. Da fraude contra sentenças, cit., p. 19.
} 
Ocorre, contudo, que, nas primeiras décadas de vigência do Regulamento 737, diferentemente do que se verifica atualmente, não havia a possibilidade de se inscrever, em registros públicos, informações sobre a pendência de ações que tivessem por objeto um bem determinado, tornando-o litigioso, ou a realização de sua penhora. ${ }^{140}$ Além disso, mesmo a obtenção de certidões nos distribuidores forenses, cautela já usualmente adotada desde então, ${ }^{141}$ mostrava-se falha, pois a ação poderia estar em curso em foro distinto do local do bem ou do domicílio do réu, ${ }^{142}$ para não mencionar a natural dificuldade de acesso às informações em decorrência das limitações tecnológicas da época.

Como se observa, o terceiro que pretendesse adquirir determinado bem não dispunha, naquela época, de meios eficazes para que pudesse saber de sua litigiosidade ou da existência de penhora sobre ele, de modo que estava sujeito a perder o bem adquirido ainda que ignorasse essas circunstâncias, até mesmo porque, considerando que a consequência da verificação dessa fraude era a nulidade do ato, ela atingia tanto terceiros imediatos como mediatos. ${ }^{143}$

Ficava evidente, portanto, que a presunção absoluta na qual se baseavam as normas dos $\S \S 1^{\circ}$ e $2^{\circ}$ do artigo $494^{\circ}$ do Regulamento 737 , na maior parte das vezes, contrariava a realidade dos fatos, gerando reação da jurisprudência contra o seu rigor, dadas as injustiças causadas aos terceiros de boa-fé.

Ainda segundo observava PHILADELPHO AzEVEDo, a constatação dessa situação de iniquidade ensejava "a precaução dos juizes em applicar o texto ou antes em ordenar a sua constante violação, pois constituia presumpção juris et de jure, independentemente de fraude do $3^{\text {o", }}$, de modo que "a jurisprudencia oscillava como em nenhum outro ponto". E, mais adiante, finalmente concluía que "confundir os 3 casos distinctos, apoiando-se em Lafayette (op. cit. § 208) foi a unica solução encontrada para

\footnotetext{
${ }^{140} \mathrm{~A}$ possibilidade de inscrição de citações de ações reais ou reipersecutórias ou de penhoras no registro de imóveis somente foi criada pelo Decreto Legislativo n. ${ }^{\circ} 4.827$, de 7 de fevereiro de 1924 , (art. $5^{\circ}$, VII e VIII), que posteriormente foi regulamentado pelo Decreto n. ${ }^{\circ} 18.542$, de 24 de dezembro de 1928 (arts. 266 e 267), cujos dispositivos, dada sua localização histórica, serão analisados no próximo item.

${ }^{141} \mathrm{Cf}$. AZEVEDO, José Philadelpho de Barros e. Da fraude contra sentenças, cit., p. 19.

${ }^{142}$ Entre outras exceções à regra geral da competência do foro do domicílio do réu (art. $60^{\circ}$ ), o Regulamento 737 previa, por exemplo, a possibilidade de eleição de foro $\left(\operatorname{art.~} 62^{\circ}\right)$, já suficiente para tornar a busca passível de falhas.

${ }^{143}$ No sistema das Ordenações, não havia dúvida de que esse terceiro mediato também respondia no caso do $\S$ 16 do Título 86 do Livro III, como atesta Lobão: "verificada com o vicio litigiosi a sciencia do litigio, procedem as ditas ordenações e é exequivel a sentença contra o terceiro que houve a cousa do condemnado (aliler se d'outra pessoa, Maced., Dec. 61, ex n. 18, Portug., L.3, C. 38, n. 35); aindaque (1. ${ }^{\circ}$ ) esse terceiro
} 
attenuar os inconvenientes e dar um certo arbitrio ao julgador, premido entre a difficil prova da fraude e os possiveis prejuizos de $3^{\text {os }}$, em boa-fé."144

Aproximadamente nessa mesma época, mas referindo-se ao ramo civil do direito processual da época, ${ }^{145}$ AUGUSTO TEIXEIRA DE FREITAS também observava reação semelhante da jurisprudência em aplicar, em sua literalidade, os dispositivos legais mais rígidos quanto à fraude de execução. ${ }^{146}$ Assim, ao comentar o artigo 926 de sua Consolidação das Leis Civis, afirmava que "nossos Juizes, não obstante essa legislação tão expressa e tão justa, mostrão-se nimiamente escrupulosos em taes execuções contra terceiros, que (dizem elles) não forão ouvidos nem condemnados; de modo que accumulão-se processos sobre processos sem a menor necessidade."147

A situação descrita acima sofreu relevante alteração em 1864, quando adveio a Lei n. ${ }^{\circ} 1.237$, de 24 de setembro daquele ano, que reformou a disciplina do Registro Geral das Hipotecas criado pelo artigo 35 da Lei n. ${ }^{\circ} 317$, de 21 de outubro de 1843, e pelo Decreto n. ${ }^{\circ} 482$, de 14 de novembro de 1846 , que o regulamentou.

Entre outras alterações, a Lei n. ${ }^{\circ}$ 1237/1864 permitiu que no Registro Geral pudesse ser transcrita a "hypotheca judicial" regulando-a em seu artigo $3^{\circ}$, $\S 12$ :

“Art. $3^{\circ}$ Esta hypotheca compete:

$\S 12$. Não se considera derogado por esta Lei o direito, que ao exequente compete, de proseguir a execução da sentença contra os adquirentes dos

não seja o immediato, mas mediato" (LOBÃO, Manuel de Almeida e Sousa. Tratado encyclopedico, pratico e critico sobre as execuções, cit., p. 66, § 59).

${ }^{144}$ AZEVEDO, José Philadelpho de Barros e. Da fraude contra sentenças, cit., p. 20 e 29 . O $\S 208$, mencionado pelo autor no trecho citado refere-se à afirmação de Lafayette de que "o direito de penhorar os bens alienados em fraude de execução só pode ser exercido, concorrendo os requisitos seguintes: I. fraude da alienação, II. ciência da fraude por parte do adquirente (conscius fraudis), III. que o executado não tenha outros bens." (PEREIRA, Lafayette Rodrigues. Direito das coisas, cit., v. 2, p. 177).

${ }^{145} \mathrm{Cf}$. ilustrado na Figura 1 do Apêndice 3 desta tese.

${ }^{146}$ No processo civil, vigia desde 1855 a Consolidação das Leis Civis, que, como era de se esperar, mantinha, quanto à fraude de execução, disciplina similar à das Ordenações Filipinas, regulando-a nos seguintes artigos:

"Art. 348. Tendo o adquirente sciência do litígio, ou razão de o saber, ao tempo em que houve a coisa litigiosa, está sujeito à execução da sentença, que o vencedor obtiver, sem que seja mais citado ou ouvido.

Art. 349. Se não sabia do litígio, nem tinha razão de saber, será ouvido com seu direito, nos termos do art. 926. (...)

Art. 926. Se o terceiro possuidor da coisa litigiosa não sabia do litígio, nem tinha razão de o saber, deve ser citado e summariamente ouvido no processo da própria execução."

${ }^{147}$ FREITAS, Augusto Teixeira de. Consolidação das leis civis. 2. ed. Rio de Janeiro: Typ. Universal de Laemmert, 1865. p. 439. 
bens do condemnado; mas, para ser opposto a terceiros conforme valer, depende de inscripção."

Esse dispositivo era - como se vê - bastante curioso. Ao contrário dos parágrafos anteriores que, como sói acontecer, ligavam-se ao caput do artigo $3^{\circ}$, dispondo que a hipoteca legal competia à mulher casada $\left(\S 1^{\circ}\right)$; aos menores e interditos $\left(\S 2^{\circ}\right)$ etc., o § 12 não tinha conexão com ele, disciplinando matéria diversa, qual seja, "o direito do exequente de prosseguir a execução contra os adquirentes dos bens do executado", que estava previsto no artigo $492^{\circ}, \S 6^{\circ}$, do Regulamento 737 , acima citado.

A conexão entre os dois dispositivos era ainda reforçada pelo texto do artigo 224 do Decreto n. ${ }^{\circ}$ 3.453, de 26 de abril de 1865, que, ao regulamentar a referida Lei n. ${ }^{\circ} 1.237 / 1864$, assim dispunha:

\footnotetext{
"Art. 224. tambem se considera especialisada pela importancia da sentença a hypotheca judicial, a qual recahirá nos immoveis do devedor condemnado, existentes na posse delle ou alienados em fraude da sentença, designados pelo exequente nos extractos do art. 53. A sentença será o titulo que servirá para inscripção, e para esse titulo se transportará o numero de ordem da prenotação."
}

Conjugando as normas dos artigos $492^{\circ}, \S 6^{\circ}$, do Regulamento 737 e $3^{\circ}, \S$ 12, da Lei . $^{\circ} 1.237 / 1864$, verifica-se que esta atuava sobre aquela de duas formas: inicialmente, esclarecia que a Lei n. ${ }^{\circ}$ 1.237/1864 não excluía o direito de executar bens alienados em fraude de execução, mas condicionava-o à inscrição da hipoteca judiciária para que pudesse ser exercido contra terceiros mediatos, o que já demonstrava preocupação em relação ao elemento subjetivo, ao menos desses terceiros.

Nesse sentido, afirmava ANTONiO DE AlMEIDA OliveIRA que "a lei presume a fraude nas alienações proximas á penhora; por isso está o exequente dispensado de proval-a mesmo em relação ao terceiro adquirente dos bens. Se o terceiro os vende á outro, tem este por si a presumpção de boa fé; mas se elle houver tomado parte na fraude do devedor e seu successor, o que deve ser provado pelo exequente, fica nas condições do 
primeiro comprador. Note-se ainda que contra o primeiro adquirente dos bens não é precisa a inscripção na hypotheca judiciaria." ${ }^{148}$

Contudo, negando a possibilidade de interpretação conjunta dessas duas normas, LAFAYETTE, alegava que "não se deve confundir a hipoteca judicial e o direito de penhorar bens alienados em fraude de execução. São direitos distintos de causas diversas, regulados por princípios diferentes, e independentes um do outro. O direito de penhorar bens alienados em fraude de execução, tem este fundamento - que a alienação fraudulenta, pois que é nula, não tira os bens do domínio do executado para o domínio do adquirente. Os ditos bens, portanto, continuam sujeitos ao pagamento das dividas do executado. $\mathrm{O}$ direito de sequela, efeito da hipoteca judiciária, resulta imediatamente da sentença e não requer como condição de sua existência a fraude da alienação.” E, em seguida, concluía que "este direito [de penhorar bens alienados em fraude de execução] não carece do vínculo hipotecário, porque, como acima se disse, a alienação em fraude de execução é nula, e como tal deixa os bens no domínio do executado, - caso em que segundo as regras comuns e sem necessidade do favor da hipoteca ficam sujeitos à execução."149

A situação era complexa e, vista à luz da moderna ciência processual, poder-se-ia apontar relevantes razões contrárias a cada um dos entendimentos.

Contra LAFAYETTE, além de apontar o equívoco historicamente superado em se entender a fraude de execução como caso de nulidade do ato jurídico, poder-se-ia argumentar com a natural interpenetração entre os dois institutos, dado, como visto, que os casos do artigo $494^{\circ}$ eram provenientes, em parte, de interpretação ampliativa da ordenação do L. III, T. 84, § 14, que tratava de hipótese de hipoteca judiciária.

Contra Antonio de Almeida OliveIRA, poder-se-ia argumentar que, diante do fato de a hipoteca judiciária estar condicionada à sentença definitiva ${ }^{150} \mathrm{e}$

\footnotetext{
${ }^{148}$ Cf. OLIVEIRA, Antonio de Almeida. A lei das execuções. Rio de Janeiro: B. L. Garnier, 1887. p. 80, nota 136. Também nesse sentido, as decisões citadas por Salustiano Orlando de Araujo Costa: "é necessaria a inscripção da hypotheca judiciaria do exequente nos bens executados, não contra o originario adquirente de taes bens em fraude de execução, mas contra terceiros, a quem estes os alienem: Rev. n. 8388 de 18 de Outubro de 1873 - Gaz. Jur., vol. 1, pag. 256." e "a inscripção não é precisa para manter à hypotheca judicial o seu effeito essencial de prosseguir a execução contra os adquirentes dos bens do condemnado: Accs. da Rel. de Ouro Preto de 7 de Agosto e 16 de Novembro de 1885 - Dir., vol. 50, pag. 574." (COSTA, Salustiano Orlando de Araujo. Código Commercial do Brasil. 7. ed. Rio de Janeiro: Livraria Francisco Alves, 1912. t. 2, p. 201/203 - destaques no original).

${ }^{149}$ Cf. PEREIRA, Lafayette Rodrigues. Direito das coisas, cit., v. 2, p. 175-176 e 178, sem colchetes no original.

${ }^{150}$ Cf. Decreto n. ${ }^{\circ} 3.453 / 1865:$ : Art. 136. As outras hypothecas serão constituidas pelo modo seguinte: (...)
} 
líquida, ${ }^{151}$ a exigência de sua inscrição prévia no Registro Geral para que o credor pudesse exercer o direito contra os terceiros mediatos acarretaria verdadeiro estímulo à fraude, uma vez que o devedor e o terceiro imediato teriam todo o tempo do curso do processo para transmitir os bens aos terceiros mediatos que, beneficiados pela "presumpção de boa fé", não poderiam ser incomodados.

Como acontece em situações como essa, a confusão existente na lei e na doutrina se fazia sentir mais fortemente na jurisprudência, registrando PHILADELPHO AZEVEDO que, nessa época, "da coexistencia dessas disposições [que regulavam os casos de fraude de execução] com a exdruxula hypotheca judicial, originava-se uma jurisprudencia perigosamente vacillante: ora deixava de annullar casos patentes de fraude sob o fundamento de não ter havido inscripção judicial (...), ora annullava casos verdadeiramente duvidosos, sem a dependencia de hypotheca, ora estendia esse direito indefinidamente considerando nullas as sucessivas transmissões."152

Prosseguindo na evolução legislativa, agora referente ao ramo civil do processo, verifica-se que, em 1876, sucedendo a Consolidação das Leis Civis de TEIXEIRA DE FReITAS, adveio a Consolidação das Leis do Processo Civil, elaborada pelo CONSElHEIRO ANTONIO JOAQUim RibAS que, ao regular o instituto da fraude de execução, já denotava a influência da Lei n. ${ }^{\circ}$ 1.237/1864 e do Decreto n. ${ }^{\circ}$ 3.453/1865:

\footnotetext{
“Art. 1.241. A sentença será executada, salvo as disposições dos artigos seguintes, contra: (...)

$\S 6 .^{\circ} \mathrm{O}$ que recebeu causa do vencido.

Art. 1.247. Receberam causa do vencido: (...)

$\S 4 .^{\circ}$ aquele a quem a cousa foi alienada, em fraude da execução, sabendo ou tendo razão para saber, desta fraude.

Art. 1.248. A disposição do $\S 4 .^{\circ}$ do artigo precedente terá lugar nas alienações:

$\S 1 .^{\circ}$ da cousa litigiosa;

$\S 2 .^{\circ}$ dos bens de raiz até o valor da condenação, pendendo sentença;
}

\footnotetext{
\$ 10. Pela sentença, e desde que ella passa em julgado, a hypotheca judiciaria.

${ }^{151} \mathrm{Cf}$. art. 224 acima citado, quando diz que a referida hipoteca judiciária "se considera especialisada pela importancia da sentença".

${ }^{152}$ AZEVEDO, José Philadelpho de Barros e. Da fraude contra sentenças, cit., p. 21, sem colchetes no original.
} 
$\S 3 .^{\circ}$ dos bens móveis depois da penhora ou imediatamente antes dela." 153

Em síntese, a Consolidação Ribas - como ficou conhecida - manteve a hipótese de fraude de execução decorrente da alienação do bem litigioso, já existente no sistema das ordenações e criou outras duas hipóteses, diferenciando-as entre bens móveis e imóveis, com marcos iniciais distintos para a sua configuração.

Assim, quanto aos bens móveis, somente as alienações posteriores à penhora ou feitas imediatamente antes dela configurariam fraude de execução. Já os bens imóveis ficariam sujeitos à fraude de execução a partir da sentença condenatória líquida, quando então já se poderia fazer a hipoteca judiciária. ${ }^{154}$

Em relação ao elemento subjetivo, verifica-se que a Consolidação Ribas o exigia para as três hipóteses, prevendo que a execução somente poderia se voltar contra o terceiro se esse soubesse ou tivesse razão para saber que sua aquisição teria se dado em alguma das circunstâncias previstas como fraude de execução (cf. art. 1.247); nesse ponto diferia do Regulamento 737, que, como visto, dispensava tal elemento nas hipóteses de alienação do bem litigioso e do bem penhorado ( $§ 1^{\circ}$ e $2^{\circ}$ do seu artigo $494^{\circ}$ ).

No entanto, os dispositivos da Consolidação Ribas sobre a fraude de execução tiveram curto período de vigência, uma vez que, menos de nove anos depois, a

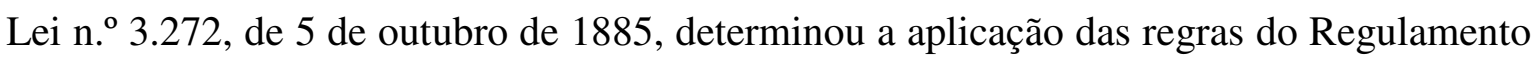
737 para as execuções cíveis, ${ }^{155}$ passando, portanto, seu artigo $494^{\circ}$ a disciplinar os casos em que as alienações eram consideradas em fraude de execução tanto em matéria comercial, quanto em matéria civil.

Interessante notar, ainda, que a mesma Lei n. ${ }^{o} 3.272 / 1885$, na parte inicial de seu artigo $7^{\circ}$, reforçava a necessidade de inscrição no Registro Geral de todas as

\footnotetext{
${ }^{153}$ RIBAS, Antonio Joaquim. Consolidação das Leis do Processo Civil commentada. Rio de Janeiro: Dias da Silva Junior, 1879. v. 2, p. 358-363.

${ }^{154}$ De fato, o próprio Ribas, em seu comentário n. ${ }^{\circ} 1.714$ ao $\S 2^{\circ}$ desse artigo 1.248 , dava conta da influência da legislação registrária na redação dessa norma, fazendo referência expressa tanto à ordenação do L. 3, T. 84, § 14, quanto aos dispositivos da Lei n. ${ }^{\circ} 1.237$, de 24 de setembro de 1864, e do Decreto n. $^{3} .453$, de 26 de abril de 1865, que tratavam da hipoteca judiciária (cf. RIBAS, Antonio Joaquim. Consolidação das Leis do Processo Civil commentada, cit., v. 2, p. 363).

${ }^{155}$ A reunião total dos processos civil e comercial somente se deu pós a proclamação da República, com a extensão da vigência do Regulamento 737 às causas cíveis pelo Decreto n. ${ }^{\circ}$ 763, de setembro de 1890.
} 
hipotecas legais previstas pela Lei n. ${ }^{\circ} 1.237 / 1864$ - entre as quais, como visto, estava a hipoteca judiciária - para surtir efeitos contra terceiros. ${ }^{156}$

Concluindo a análise desse primeiro período da história do instituto, observa-se que a feição atribuída ao elemento subjetivo era a má-fé do terceiro decorrente não apenas da ciência efetiva, mas também da existência de razão para este saber da pendência da ação e da insolvência do devedor. A demonstração desse fato, nessa época, geralmente era feita por meio de "prova por presunção", sendo muito importantes as presunções clássicas de fraude, como a alienação ter se dado entre parentes ou amigos, ou por preço vil, ou com a permanência do devedor na posse do bem.

Pelo sistema do Regulamento 737, que após 1885 passou a ser aplicado não só às causas comerciais, mas também às cíveis, o elemento subjetivo era irrelevante para a configuração das hipóteses de fraude de execução previstas nos $\S \S 1^{\circ}$ e $2^{\circ}$ de seu artigo $494^{\circ}$ - alienação de bem litigioso e de bem penhorado ou na iminência da penhora.

No entanto, já se verificava, naquela época, a existência de crescente preocupação com a relevância do elemento subjetivo, seja por parte da doutrina e da jurisprudência, que diante dos riscos a terceiros de boa-fé admitia a sua análise mesmo contra o texto dos $\S \S 1^{\circ}$ e $2^{\circ}$ do referido artigo $494^{\circ}$; seja pelo legislador, que acabou por condicionar, no caso de alienação de bens sujeitos a hipoteca, a extensão dos efeitos da fraude de execução aos terceiros mediatos à prévia inscrição de hipoteca judiciária no Registro Geral.

\section{2- Segundo período (1890-1939): a legislação federal, os códigos estaduais e a gradual conquista do paralelismo entre as regras processuais e registrárias}

Com a proclamação da República e a promulgação da Constituição de 1891, o regramento do processo civil recém-unificado foi novamente cindido, pois tanto a União Federal quanto os Estados receberam competência para legislar sobre processo.

\footnotetext{
156" Art. $7^{\mathbf{o}}$ As hypothecas legaes de toda e qualquer especie em nenhum caso valerão contra terceiros, sem a indispensavel formalidade da inscripção, ficando designado o prazo de um anno, da presente Lei, para a inscripção daquellas a que se refere o art. 123 do Regulamento n. 3453 de 26 de Abril de 1865, e que, anteriormente constituidas, não tenham ainda sido inscriptas." $\mathrm{O}$ artigo 123 mencionado nessa segunda parte referia-se às hipotecas legais das mulheres casadas, menores ou interditos, que originalmente valiam contra terceiros mesmo que não estivessem inscritas.
} 
O processo civil aplicável às causas federais passou a ser regido pelo Decreto n. ${ }^{\circ} 848$, de 11 de outubro de 1890, e, posteriormente, pela Consolidação das Leis Referentes à Justiça Federal, organizada por José HigINO DUARTE PEREIRA e aprovada pelo Decreto n. ${ }^{\circ}$ 3.084, de 5 de novembro de 1898. Em relação à fraude de execução, o Decreto n. ${ }^{\text {8 }} 848 / 1890$ a disciplinava em seus artigos 246, "f", e $247^{157}$ e o Decreto n. ${ }^{\circ}$ 3.084/1898, nos artigos 491, "f", e 493 de sua Terceira Parte, ${ }^{158}$ que praticamente reproduziam os artigos $492^{\circ}, \S 6^{\circ}$, e $494^{\circ}$ do Regulamento 737 . Valem, portanto, para aqueles, as mesmas observações já feitas para esses no item anterior.

Permanecia também nesse período a mesma disciplina referente à hipoteca judiciária, uma vez que o Decreto n. 169 A, de 19 de janeiro de 1890, repetiu em seu artigo $3^{\circ}, \S 11,{ }^{159}$ a norma antes prevista no $\S 12$ do artigo $3^{\circ}$ da Lei n. $.^{\circ} 1.237 / 1864$; e o Decreto n. ${ }^{\circ} 370$, de 2 de maio de 1890, repetiu em seu artigo $201,{ }^{160}$ o texto do artigo 224

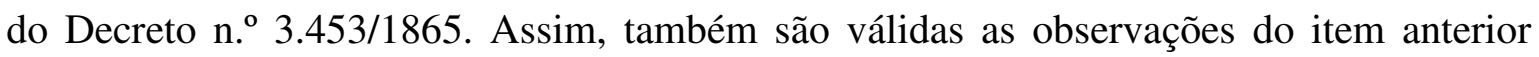
quanto às interações entre os dispositivos processuais e os da legislação registrária.

Usando da competência que lhes foi outorgada, os Estados criaram seus códigos processuais, revogando, em seus territórios, as normas do Regulamento 737. Como se pretende analisar a origem do atual artigo 593 do CPC, não serão abordados aqui todos os códigos promulgados pelos Estados brasileiros naquela época, mas apenas os do Rio Grande do Sul, da Bahia, do Rio de Janeiro, de Minas Gerais, do Distrito Federal e de São Paulo, dos quais foi extraído o maior número de contribuições para a elaboração do

157"Art. 246. É competente a execução contra: (...)

f) o comprador ou o possuidor de bens hypothecados, segurados, alienados em fraude da execução, e em geral contra todos os que recebem causa do vencido, como o comprador da herança;"

"Art. 247. Consideram-se alienados em fraude da execução os bens do executado:

a) quando são litigiosos, ou sobre elles pende demanda;

b) quando a alienação e feita depois da penhora, ou proximamente a ella;

c) quando o possuidor dos bens tinha razão, para saber que pendia demanda, e outros bens não tinha o executado para solver a divida."

158"Art. 491. É competente a execução contra: (...)

f) o comprador ou o possuidor de bens hypothecados, segurados, alienados em fraude da execução, e em geral contra todos os que recebem causa do vencido, como o comprador da herança;"

"Art. 493. Consideram-se alienados em fraude da execução os bens do executado:

a) quando são litigiosos ou sobre elles pende demanda;

b) quando a alienação e feita depois da penhora ou proximamente a ella;

c) quando o possuidor dos bens tinha razão para saber que pendia demanda, e outros bens não tinha o executado por onde pudesse pagar."

$159 " § 11$. Não se considera derogado por este decreto o direito, que ao exequente compete, de proseguir a execução da sentença, contra os adquirentes dos bens do condemnado; mas, para ser opposto a terceiros, conforme valer, depende de inscripção (art. $9^{\circ}$ ) e especialisação." 
Código de Processo Civil de 1939, segundo Pedro Batista Martins, autor do seu anteprojeto. $^{161}$

O Código de Processo Civil e Comercial do Rio Grande do Sul, instituído pela Lei n. ${ }^{\circ}$ 65, de 16 de janeiro de 1908, assim dispunha sobre a fraude de execução:

\begin{abstract}
“Art. 984. Considera-se a acquisição feita em fraude de execução:
$1^{\circ}$ Quando effectuada nos trinta dias antecedentes à penhora, ou depois desta;

$2^{\circ}$ Quando o adquirente tinha razão para saber que pendia demanda, e outros bens não tinha o executado por onde pudesse pagar." 162
\end{abstract}

Observa-se, de imediato, que o código processual gaúcho separou da disciplina da fraude de execução a hipótese de alienação da coisa litigiosa, que antes era tratada no $\S 1^{\circ}$ do artigo $494^{\circ}$ do Regulamento 737 , preferindo tratar dessa hipótese em seu artigo 957, que integrava capítulo dedicado à “execução por cousa certa ou em espécie”. 163

Em relação às duas hipóteses do artigo 984 acima citado, pode-se dizer que o Código de Processo Civil e Comercial do Rio Grande do Sul procurou estabelecer objetivamente o que entendia por "proximidade da penhora" antes prevista no $\S 2^{\circ}$ do art. $494^{\circ}$ do Regulamento 737, fixando o período de 30 dias anteriores à penhora para que a alienação fosse considerada em fraude de execução. ${ }^{164}$

\footnotetext{
160"Art. 201. Tambem se considera especializada pela importancia da sentença a hypotheca judicial, a qual recahirá nos immoveis do devedor condemnado, existentes na posse delle, ou alienados em fraude da sentença, que o exequente designar nos extractos do art. 50."

${ }^{161}$ MARTINS, Pedro Batista. Em defesa do ante-projeto de Código de Processo Civil. Revista Forense, Rio de Janeiro, n. 78, p. 416, abr./jun. 1939.

${ }^{162}$ RIO GRANDE DO SUL. Codigo do Processo Civil e Commercial do Estado do Rio Grande do Sul. Edição Oficial. Porto Alegre: Officinas Typographicas d’A Federação, 1908. p. 191.

${ }^{163}$ Assim dispunha o referido artigo:

"Art. 957. Si o executado dentro em dez dias não entregar a cousa por ter sido alienada depois de litigiosa, correrá a execução contra o terceiro, de cujo poder se tirará a cousa, sem que seja ouvido antes de ser ella depositada, ou seguro o juízo pela forma indicada no artigo 965." (RIO GRANDE DO SUL. Codigo do Processo Civil e Commercial do Estado do Rio Grande do Sul, cit., p. 185).

${ }^{164}$ Comentando esse dispositivo, dizia Oswaldo Vergara que "o Reg. 737 dispõe de modo diverso, dando largas à interpretação. (...) O nosso Codigo para desatar qualquer duvida na interpretação ou intendimento do adverbio proximamente, fixou prazo de 30 dias." (CODIGO do Processo Civil e Commercial do Estado do Rio Grande do Sul com a jurisprudencia do Superior Tribunal do Estado até 1920, com innumeros commentarios de doutrina e com as modificações introduzidas pelo Codigo Civil brasileiro. 2. ed. Porto Alegre: Livraria do Globo, 1922. p. 459).
} 
No que diz respeito à relevância do elemento subjetivo, verifica-se que entre os dispositivos do código gaúcho, apenas o $§ 2^{\circ}$ do seu artigo 984 o previa, fazendo-o também sob a feição da má-fé apenas do terceiro decorrente da existência de razão para que esse soubesse da pendência da demanda e da ausência de outros bens do executado para a sua satisfação. No caso do $\S 1^{\circ}$, tal elemento era irrelevante: sendo alienado a partir de trinta dias antes da penhora, o bem poderia sofrer a execução no patrimônio do terceiro, soubesse ele ou não da iminência da constrição. ${ }^{165}$

Diferentemente da lei processual gaúcha, o Código do Processo do Estado da Bahia, promulgado em 21 de agosto de 1915, manteve a mesma disciplina da fraude de execução existente no Regulamento 737:

“Art. 1.062. A execução pode ser movida: (...)

6. ${ }^{\circ}$ contra o comprador ou possuidor de bens hypothecados, segurados, alienados em fraude da execução e, em geral, contra todos os que receberam causa do vencido, como o comparador da herança.

Art. 1.063. Consideram-se alienados em fraude da execução os bens do executado:

$1^{\circ}$ quando são litigiosos ou sobre elles pende demanda;

$2^{\circ}$ quando a alienação é feita depois da penhora ou proximamente a ella;

$3^{\circ}$ quando o adquirente tinha razão de saber que pendia demanda e outros bens não possuía o alienante por onde pudesse pagar.",166

Especificamente em relação ao elemento subjetivo, EDUARDO ESPÍNOLA esclarecia que somente na hipótese do parágrafo $3^{\circ}$ do artigo 1.063 acima transcrito é que o legislador exigiu a ciência ou a possibilidade de ciência do adquirente. Além disso, já escrevendo após a promulgação do Código Civil de 1916, o autor fazia interpretação conjunta do dispositivo da lei processual baiana com o artigo 106 daquele código e, com base em julgado de SORIANO DE SOUSA FILHO, sustentava a desnecessidade de

\footnotetext{
${ }^{165}$ Philadelpho Azevedo criticava essa construção, pois, tendo em vista que em seu artigo 873 o código gaúcho já tratava as execuções e as ações executivas (fundadas em títulos extrajudiciais) conjuntamente, o estabelecimento do período de 30 dias anteriores à penhora tornava sua disciplina da fraude de execução "num systema tão rigoroso quanto o das fallencias" (AZEVEDO, José Philadelpho de Barros e. Da fraude contra sentenças, cit., p. 20).

${ }^{166}$ ESPÍNOLA, Eduardo. Código de Processo do Estado da Bahia anotado. Bahia: Typ Bahiana, 1916. p. 121-122.
} 
demonstração da ciência do terceiro para a configuração da fraude de execução nos casos de alienação a título gratuito. ${ }^{167}$

De fato, a promulgação do Código Civil, em $1^{\circ}$ de janeiro de 1916, foi outra relevante interferência na disciplina da fraude de execução. Em primeiro lugar, porque encampou em seu artigo 824 a regra surgida no $\S 12$ do artigo $3^{\circ}$ da Lei n. ${ }^{\circ}$ 1.237/1864 - e repetida pelo $\S 11$ do artigo $3^{\circ}$ do Decreto n. ${ }^{\circ} 169$ A/1890 então vigente -, que estabelecia, como visto, o registro da hipoteca judiciária como condição para se alcançar, no patrimônio de terceiros mediatos, os bens alienados pelo devedor: ${ }^{168}$

\begin{abstract}
"Art. 824. Compete ao exequente o direito de prosseguir na execução da sentença contra os adquirentes dos bens do condenado; mas, para ser oposto a terceiros, conforme valer, e sem importar preferência, depende de inscrição e especialização."
\end{abstract}

Em segundo lugar, porque o Código Civil disciplinou em seus artigos 106 a 113 a figura da fraude contra credores, havendo autores, como o acima citado EDUARDO ESPÍNOLA, que admitiam a interpretação conjunta dos dois sistemas e outros, como Philadelpho Azevedo, que até mesmo defendiam a revogação das regras dos códigos de processo estaduais sobre fraude de execução no que conflitassem com as previstas no Código Civil para a fraude contra credores. ${ }^{169}$

\footnotetext{
${ }^{167}$ Cf. ESPÍNOLA, Eduardo. Código de Processo do Estado da Bahia anotado, cit., v. 2, p. 355-357.

${ }^{168}$ Para não haver dúvida que os "terceiros" mencionados no artigo 824 são os "terceiros mediatos" e não os "imediatos", além dos dispositivos que antecederam esse artigo nos diplomas de 1864 e 1890, deve-se notar que o próprio Código Civil revogado, ao tratar da fraude contra credores, em seu artigo 109, também utilizou a mesma terminologia, diferenciando os "terceiros adquirentes" da "pessoa que com ele [devedor] celebrou a estipulação considerada fraudulenta".

${ }^{169 "}$ "As unicas disposições expressas sobre revogação de actos fraudulentos, ainda que de uso indirecto, que possuiamos eram as do Reg. 737 e o Codigo [Civil] dispondo sobre essa materia evidentemente a revogou, embora seja perfeitamente acceitavel separar a parte de fundo e a de forma ali reunidas, para que attingida uma, possa a outra vigorar, na falta de proibição expressa (...). Assim, se entende perfeitamente mantido o art. $492 \S 6^{\circ}$ (parte formal), substituidas as condições (parte material) do art. 494 pelo disposto no Codigo [Civil]." Por fim, concluía: "o direito de penhorar bens alienados em fraude de execução, meio efficaz ainda que penoso como estabelecia o art. 494 do Regulamento [737] de 1850, foi modificado pelo disposto nos arts. 106 a 113 do Codigo Civil, exigindo-se os seguintes requisitos: $1^{\circ}$ - insolvencia, isto é, falta de bens sufficientes para pagamento das dividas (art. 1554), nos atos de transmissão gratuita; $2^{\circ}$ - notoriedade dessa insolvencia ou motivos para ser conhecida pelo adquirente, nos contractos onerosos; $3^{\circ}-$ má-fé comprovada no caso de $3{ }^{\text {os }}$ mediatos. O juiz apreciará segundo as circunstâncias do caso e as presumpções estabelecidas pela doutrina a situação de insolvencia notoria." (AZEVEDO, José Philadelpho de Barros e. Da fraude contra sentenças, cit., p. 26, 32 e 37, sem colchetes no original).
} 
O Código Judiciário do Rio de Janeiro, instituído pela Lei n. $^{\circ} 1.580$, de 20 de janeiro de 1919, tornou ainda mais evidente a influência exercida pelo Código Civil sobre a disciplina da fraude de execução, assim dispondo em seus artigos 2.138 e 2.139:
“Art. 2.138. É competente a execução contra: (...)
$3^{\circ}$. o comprador ou o possuidor de bem hypothecado, segurado ou alienado em fraude de execução, e, em geral, contra todos os que recebem causa do vencido, como o comprador da herança; (...)

Art. 2.139. Consideram-se alienados em fraude de execução os bens do executado:

$1^{\circ}$. quando são litigiosos ou sobre elles pende demanda;

$2^{\circ}$. quando a alienação for feita depois da penhora ou proximamente a ella;

$3^{\circ}$. Quando houver, por qualquer forma, simulação, dolo ou fraude contra credor, nos termos do Código Civil.,"170

Segundo se nota, nas duas primeiras hipóteses, manteve-se inalterada a disciplina dos $\S \S 1^{\circ}$ e $2^{\circ}$ do artigo $494^{\circ}$ do Regulamento 737. Já na terceira, houve substancial modificação, tendo o Código Judiciário do Rio de Janeiro se reportado expressamente ao Código Civil, no tocante à fraude contra credores, ao dolo e à simulação.

Pode-se dizer, portanto, que, em relação à relevância do elemento subjetivo na fraude de execução, o código fluminense admitiu-a somente na $3^{\text {a }}$ hipótese do artigo 2.139 e, ao se reportar às regras do Código Civil, limitou-a à má-fé do terceiro, decorrente da existência de motivo para que esse soubesse da insolvência do devedor e exigida apenas nos casos de alienação a título oneroso. ${ }^{171}$

O Código do Processo Civil de Minas Gerais, Lei n. ${ }^{\circ}$ 830, de 7 de setembro de 1922, também manteve a disciplina da fraude de execução em termos similares aos do Regulamento $737 .{ }^{172}$ Além disso, reportou-se ao Código Civil para

\footnotetext{
${ }^{170}$ BASTOS, José Tavares. Código Judiciário do Estado do Rio de Janeiro. Rio de Janeiro: Jacintho Ribeiro dos Santos, 1919. p. 144-145).

${ }^{171}$ Cf. a interpretação de Clóvis Bevilacqua e Pontes de Miranda dos arts. 106 e 107 daquele código já citada na nota 114, supra.

${ }^{172}$ Nesse sentido, afirmou Arthur Ribeiro, autor do anteprojeto desse código estadual: "visto tratar-se de alienação, preferi, à imitação do Cod. da Bahia, substituir a expressão possuidor dos bens pelo vocábulo adquirente. No mais, preferi conservar a redacção do texto do regul. n. 737" (OLIVEIRA, Arthur Ribeiro de. Codigo do Processo Civil com annotações. Belo Horizonte: Imprensa Oficial, 1922. p. 382).
} 
mencionar que, nas hipóteses de fraude contra credores, diferentemente das de fraude de execução, há necessidade de prévia anulação do ato, mediante ação própria, para que a execução pudesse se fazer sobre os bens de terceiro:

“Art. 1.289. É competente a execução contra a parte vencida ou contra qualquer que della tenha recebido a causa ou a quem o julgado prejudique, como: (...)

5) o comprador ou possuidor de bens hypothecados, segurados ou alienados em fraude de execução; (...)

Art. 1.290. Consideram-se alienados em fraude da execução os bens do executado:

1) quando são litigiosos ou sobre elles pende demanda;

2) quando a alienação é feita depois da penhora ou proximamente a ella;

3) quando o adquirente tinha razão de saber que pendia demanda e outros bens não possuía o alienante por onde pudesse pagar.

$\S 1^{\circ}$ Fora esses casos, os actos de alienação em fraude do credor devem ser annullados, mediante acção competente, afim de que a execução possa recahir sobre os bens alienados.

$\S 2^{\circ}$ Compete ao exeqüente o direito de prosseguir na execução da sentença contra os adquirentes dos bens do condemnado; mas, para ser apposta a terceiro, conforme valer, e sem importar preferência, depende de inscripção e especialização." ${ }^{, 73}$

Como se observa, em relação à feição e relevância do elemento subjetivo para a fraude de execução, o código mineiro segue mesma linha do Regulamento 737.

Além disso, observa-se que foi inserida no $\S 2^{\circ}$ do artigo 1.290 a norma referente à hipoteca judiciária, que desde 1916 estava prevista no artigo 824 do Código Civil. Pela primeira vez, portanto, colocavam-se lado a lado, dentro do mesmo artigo as duas normas, indicando claramente que ambas estavam interligadas e servindo a segunda para limitar a eficácia da primeira quanto aos terceiros mediatos, como defendera ANTONIO DE ALMEIDA OlIVEIRA no trecho anteriormente citado no item 4.1, supra.

Em 1924, adveio outra alteração na legislação relativa aos registros públicos que teve impacto relevante na disciplina da fraude de execução. Trata-se da

${ }^{173}$ LAGOEIRO, Manoel. Commentarios ao Codigo do Processo Civil. Belo Horizonte: Imprensa Official, 1930. p. 143-144. 
possibilidade de inscrição, no registro imobiliário, da penhora e da citação de ação real ou reipersecutória, criada pelo Decreto Legislativo n. ${ }^{\circ} 4.827$, de 7 de fevereiro de 1924:

“Art. $5^{\circ}$ No registro de immoveis far-se-ha:

a) a inscripção: (...)

VII- das penhoras, arrestos e sequestros de immoveis;

VIII- das citações de acções reaes ou pessoaes reipersecutorias, relativas a immoveis;", 174

Com essa possibilidade, ampliava-se o âmbito da publicidade decorrente do registro de imóveis para possibilitar o conhecimento de terceiros quanto a situações de alienação de bens em fraude de execução.

Até então, como visto, o credor somente poderia inscrever a hipoteca judiciária após o trânsito em julgado e a liquidação da sentença condenatória, excluindo da publicidade do registro os casos de fraude de execução decorrentes de alienações ocorridas durante todo o curso do processo e ainda os decorrentes de ações reais.

Com a possibilidade criada pelo Decreto Legislativo n. ${ }^{\circ} 4.827$, de 7 de fevereiro de 1924, permitia-se que a publicidade do registro também incidisse nos casos de alienação de bens litigiosos imóveis, desde a citação do réu, e de bens penhorados, desde a constrição, permitindo que terceiros tivessem ciência dessas circunstâncias e, portanto, pudessem optar por deixar de adquirir os bens ou assumir o risco de perdê-los em razão do reconhecimento da fraude de execução.

Passados, portanto, quase 75 anos desde o início da vigência do Regulamento 737, a legislação registrária havia se alinhado com os casos previstos nos $\S \S$ $1^{\circ}$ e $2^{\circ}$ de seu artigo $494^{\circ}$, aproximando da realidade dos fatos a presunção absoluta da possibilidade de ciência de terceiros que neles estava contida.

Deve-se observar, contudo, que a possibilidade de inscrição das penhoras e das citações em ações reais ou reipersecutórias no registro imobiliário não trazia, por si só, qualquer alteração nos casos de fraude de execução já previstos na legislação

\footnotetext{
${ }^{174}$ O Decreto Legislativo n. ${ }^{\circ}$ 4.827/1924 ainda previa, no inciso V desse mesmo artigo a inscrição das hipotecas legais ou convencionais, abrangendo também, entre as legais, a hipoteca judiciária.
} 
processual federal e nos códigos estaduais. Apenas permitia-se agregar publicidade a esses atos, evitando, com isso, as situações injustas já relatadas, em que o terceiro perdia o bem, ainda que não tivesse meios de saber que era objeto de penhora ou ação real ou reipersecutória.

É verdade, porém, que os códigos processuais posteriores, como os do Distrito Federal e de São Paulo, apoiaram-se na alteração da legislação registrária para condicionar a configuração da fraude de execução à inscrição da penhora ou da citação do réu em ação real ou reipersecutória no registro imobiliário.

Realmente, o Código de Processo Civil e Comercial para o Distrito Federal, promulgado pelo Decreto n. ${ }^{\circ} 16.752$ em 31 de dezembro de 1924, já denotava a influência do Decreto n. ${ }^{\circ}$ 4.827/1924 ao disciplinar a fraude de execução:

“Art. 903. É exequível a sentença contra: (...)

VI. o comprador, ou possuidor, de bens hypothecados, ou alienados, em fraude de execução e, em geral, todos os que receberam causa do vencido, como o comprador da herança; (...)

Art. 969. Consideram-se alienados os bens em fraude da execução:

I. quando sobre elles é movida acção real, ou reipersecutória;

II. quando a alienação for feita depois de protestado o título exequiendo, nos casos de acção executiva;

III. quando já houver inscripção de penhora, arresto, ou seqüestro;

IV. quando o adquirente tinha razão de saber que pendia demanda contra o devedor e não possuía este outros bens para o pagamento."

Nota-se, portanto, que tais dispositivos também seguem a linha adotada pelo Regulamento 737, com exceção dos incisos II e III do artigo 969, em que o legislador, de certo modo, acabou por cindir a hipótese do $\S 2^{\circ}$ do artigo $494^{\circ}$ daquele regulamento.

Assim, na hipótese prevista no inciso II do artigo 969, o código do Distrito Federal previu que, nos casos de título extrajudicial, bastaria o seu protesto para a configuração da fraude de execução, tornando mais clara a ideia que antes se extraía da

${ }^{175}$ GUSMÃO, Helvecio de. Código do Processo Civil e Commercial para o Districto Federal. Rio de Janeiro: Jacyntho Ribeiro dos Santos, 1931. p. 586 e 589. 
expressão "proximamente à penhora" prevista na norma do Regulamento 737 e procurando atrelá-la ao protesto do título, ato que também já era dotado de alguma publicidade. ${ }^{176}$

No inciso III do mesmo artigo, esse código exigia a inscrição do ato de constrição no registro de imóveis para a configuração da fraude de execução, como já permitia o Decreto n. ${ }^{\circ} 4.827 / 1924$.

Verifica-se, contudo, que esse inciso III não distinguia a alienação feita a terceiros imediatos da feita a terceiros mediatos, como a regra da hipoteca judiciária que então vigia no artigo 824 do Código Civil e no $§ 2^{\circ}$ do artigo 1.290 do código processual mineiro. A exigência da inscrição da penhora se aplicava para todos os casos, de modo que, se a penhora não estivesse inscrita no registro imobiliário, a aquisição do bem penhorado não configuraria fraude de execução mesmo feita diretamente do devedor.

Interessante notar, ainda, que o código do Distrito Federal não exigia, para a configuração da fraude de execução prevista no inciso I de seu artigo 969, a necessidade de inscrição da citação em ações reais e reipersecutórias no registro imobiliário, embora essa também estivesse prevista no Decreto n. ${ }^{\circ}$ 4.827/1924. Possível explicação para tal fato reside na interpretação de que, em razão do sistema real adotado pelo Código Civil, o credor poderia prosseguir na "execução das sentenças em acções reaes sobre os bens litigiosos, independente da circunstância da fraude." 177

De toda forma, observa-se que, em relação às hipóteses dos incisos II e III, o legislador do Distrito Federal demonstrou preocupação em atrelar as hipóteses de fraude de execução dos bens penhorados ou sujeitos a penhora iminente a alguma forma de publicidade, tornando possível que os terceiros tivessem ciência das circunstâncias em que a aquisição estava sendo realizada.

Comentando o referido artigo 969, afirmava HELvécIO DE GUSMÃo que “o n. II contém, na sua primeira parte, uma innovação no processo civil (...) o fim do protesto é (...) dar sciencia aos co-obrigados no título cambial de que este não foi pago pelo seu emittente na época do seu respectivo vencimento. A tendência, porém, é para se dar maior extensão aos effeitos do protesto, e entre eles, está o de autorisar a presumpção de fraude nas alienações de bens do devedor por este feitas após o protesto ou proximamente

\footnotetext{
${ }^{176}$ Cf. artigo 29, IV, do Decreto n. ${ }^{\circ} 2.044$, de 31 de dezembro de 1908.

${ }^{177}$ Cf. AZEVEDO, José Philadelpho de Barros e. Da fraude contra sentenças, cit., p. 37.
} 
a elle. (...) o n. III é outra novidade, fazendo decorrer a presumpção de fraude da inscripção a penhora, arresto, ou seqüestro, quando devel-o-ia ser da simples effectivação dessa medida. Mais acautelador era o $\S 2^{\circ}$ do Reg. 737 que deveria ter sido mantido, pois a fraude de que se trata é a do executado e não do seu credor."178

No que diz respeito ao elemento subjetivo, o código do Distrito Federal apenas exigia a sua demonstração para a configuração da hipótese de fraude de execução prevista no número IV de seu artigo 969 , que reproduziu o texto do $\S 3^{\circ}$ do artigo $494^{\circ}$ do Regulamento 737. A feição de tal elemento era, portanto, a má-fé do terceiro, decorrente da existência de razão para que esse soubesse da pendência da ação e da insuficiência do patrimônio do devedor.

Em 1928, outra alteração na legislação relativa aos registros públicos foi decisiva para a disciplina da fraude de execução. Trata-se da edição do Decreto n. ${ }^{\circ} 18.542$, 24 de dezembro daquele ano. O novo decreto, além de, em seu artigo 173, IV, VI e VII, repetir a possibilidade de inscrição no registro imobiliário de hipotecas legais, penhoras e citações em ações reais e reipersecutórias relativas a imóveis, já previstas no então vigente Decreto Legislativo n. ${ }^{\circ}$ 4.827/1924, especificava, em seus artigos 258, 266 e 267, os efeitos que a inscrição de cada um desses atos teria em relação à fraude de execução:

“Art. 258. Considerar-se-á tambem especializada e apenas dependente de inscripção a hypotheca judicial, mediante mandado ou carta de sentença quando esta fôr liquida, quanto aos bens existentes em posse do condemnado ou alienados em fraude de execução. Em caso contrario, apurar-se-á provisoriamente o valor da responsabilidade, sem prejuizo do processo de liquidação.

$\S 1^{\circ}$ Mesmo a sentença recorrida, qualquer que seja o seu effeito, autorizará a inscripção com caracter condicional, fazendo-se observação a respeito.

$\S 2^{\circ} \mathrm{O}$ credor indicará, em petição, os immoveis sobre os quaes deve recahir a inscripção, com os requisitos necessarios, ficando salvo ao devedor requerer ao juiz competente a reducção ou substituição dos immoveis apontados. (Dec. $n$. 370 cit., art. 201 e Cod. Civ., art. 824.)

Art. 266. A inscripção da penhora importará na prova de fraude de qualquer transacção posterior. (Dec. n. 737, de 1850, art. 494 e codigos processuaes.)

Art. 267. Inscriptas no livro 4, serão as acções reaes ou pessoaes reipersecutorias, inclusive possessorias, quando fôr o caso, e as de rectificação de registro, pelas certidões das citações com os mesmos requisitos do art. 265, no que fôr applicavel, averbando-se as decisões, recursos e seus effeitos e ficando desde logo considerados os bens como litigiosos para o effeito de

\footnotetext{
${ }^{178}$ GUSMÃO, Helvecio de. Código do Processo Civil e Commercial para o Districto Federal, cit., p. 590.
} 
apreciação da fraude de posteriores alienações. (Lei n. 4.827 cit., art. $5^{\circ}$, a, VII.)."

De início, já se observa que o artigo 258 do Decreto n. ${ }^{\circ} 18.542 / 1928$ trouxe relevante alteração para o regime da hipoteca judiciária. A base do texto do novo dispositivo era semelhante àquela dos artigos 201 do Decreto n. $370 / 1890$ e 224 do Decreto n. ${ }^{\circ}$ 3.453/1865 que o antecederam, mas continha três alterações que ampliavam sobremaneira o alcance e a utilidade da hipoteca judiciária antes tão criticados. ${ }^{179}$

Em primeiro lugar, a hipoteca judiciária deixava de estar limitada apenas às sentenças já transitadas em julgado, podendo ser utilizada ainda que pendesse recurso.

Em segundo lugar, permitia-se a sua utilização também para sentenças ilíquidas e, nesse ponto, o decreto previa a realização de uma forma provisória de apuração do valor da condenação, sem prejuízo do procedimento de liquidação.

Em terceiro lugar - e, em contrapartida, para o equilíbrio do sistema -, o $\S 2^{\circ}$ do artigo 258 previa a possibilidade de o devedor requerer ao juiz competente a redução ou a substituição dos imóveis hipotecados. Essa medida era salutar, pois, de um lado, evitava-se que o credor obtivesse garantia superior ao seu crédito onerando demais o patrimônio do devedor e, de outro, permitia-se a este a disposição de seus bens sem a perda da garantia do credor, dando-lhe a possibilidade de substituir o bem onerado.

Quanto à inscrição da penhora, o artigo 266 do Decreto n. ${ }^{\circ}$ 18.542/1928 limitou-se a dizer que essa fazia "prova da fraude de qualquer transação posterior". Entendia-se, com essa expressão, que a inscrição da penhora no registro imobiliário, tal qual a inscrição da hipoteca judiciária, gerava presunção absoluta da possibilidade de seu conhecimento em relação a terceiros.

\footnotetext{
${ }^{179}$ Por todos, confira-se a crítica de Philadelpho Azevedo: "chegando ao ponto principal da questão, vejamos quaes as vantagens da hypotheca como meio de prevenção à fraude. Seria ella de facto util e conveniente? Não hesitamos em responder pela negativa, limitada como era ao direito de sequela (...) A hypotheca judicial, adoptada na França e na Italia, goza cumulativamente, além desse [refere-se aqui à sequela], dos três effeitos acima apontados: a preferencia, a generalidade e a condicionalidade (...) A concessão da hypotheca com caracter condicional às sentenças finaes de $1^{\mathrm{a}}$ instancia, pendentes de recurso, não só compensaria a falta dos demais requisitos, como importaria em creação superior à francesa ou à italiana." (AZEVEDO, José Philadelpho de Barros e. Da fraude contra sentenças, cit., p. 13 e 16 - sem colchetes no original).
} 
Por fim, o artigo 267 desse decreto referia-se à inscrição das citações das ações reais, pessoais reipersecutórias - incluindo-se as possessórias - e de retificação de registro, estabelecendo que feita essa inscrição seriam "desde logo considerados os bens como litigiosos para o effeito de apreciação da fraude de posteriores alienações”. Assim, a litigiosidade dos bens passava a decorrer não da própria citação, como tradicionalmente ocorria, mas da inscrição dessa citação no registro imobiliário.

As alterações promovidas pelo Decreto Legislativo n. ${ }^{\circ} 4.827 / 1924$, pelo Código de Processo Civil e Comercial para o Distrito Federal e pelo Decreto n. ${ }^{\circ}$ 18.542/1928, há pouco analisadas, tiveram grande influência de PHILADELPHO AzEVEDO.

No final de sua obra, publicada em 1920, o autor apresentava algumas sugestões para a melhoria do sistema de combate à fraude de execução. A primeira seria permitir a inscrição, no registro público, das ações reais e das hipotecas judiciais, para as ações condenatórias, desde o início do processo, evitando que os interessados tivessem de se valer da "cautela sempre falha de certidões dos distribuidores". A segunda, dizia o autor, "si o receio de abusos por acções infundadas, se oppuzesse entre nós a tal innovação", seria "que ao menos se a determinasse [refere-se aqui à hipoteca judiciária] para todas as sentenças de primeira instancia". E, por fim, "evitando um numero menor de atos fraudulentos, mas applicavel, p. ex., nas acquisições sucessivas," sugeria em terceiro lugar “o systema de inscripção no registro real das penhoras sobre immoveis, pois a simples prohibição da venda, sem publicidade, como estava no Reg. 737, atentava contra o regime da propriedade immobiliaria, podendo dar logar a prejuizos a terceiros de bôa-fé, ignorantes de uma penhora relativa às vezes a execuções ajuizadas em logar diverso." 180

\footnotetext{
${ }^{180}$ AZEVEDO, José Philadelpho de Barros e. Da fraude contra sentenças, cit., p. 40-41, sem colchetes no original. Segundo relata o autor em sua obra, em 1920, essas sugestões já haviam sido enviadas para a comissão que estava elaborando o projeto do código processual do Distrito Federal e iriam sê-lo para discussão da comissão federal responsável pelo projeto de regulamentação dos registros públicos. Também esse o relato de Sérgio Jacomino: "o grande jurista brasileiro Philadelpho Azevedo, em sessão realizada a 8 de junho de 1921 no Instituto da Ordem dos Advogados Brasileiros, indicava a necessidade de colaborar na feitura dessa importante lei [refere-se ao Decreto Legislativo n. ${ }^{\circ}$ 4.827/1924], sugerindo um parecer da Ordem. Foi nomeada uma comissão, composta por Eduardo Duvivier, o próprio Philadelpho Azevedo, que foi o relator, sob a direção do professor Alfredo Bernardes. O parecer foi apresentado na sessão de 29 de junho de 1921, aprovado pelo instituto a 7 de julho do mesmo ano e logo encaminhado ao Senado. Assim, atendendo à sugestão da douta comissão, figurou no Regulamento de 1924 (art. 5º "a", VII e VIII) a inscrição das penhoras, arrestos, sequestros e das citações de ações reais ou pessoais reipersecutórias." (JACOMINO, Sérgio. A averbação premonitória, publicidade registral e distribuidores: a probatio diabolica e o santo remédio. Boletim do IRIB em Revista, n. 331, p. 12, abr./jun. de 2007). Já quanto à participação de Philadelpho Azevedo, em 1927, como membro da comissão para discussão do texto que originou o Decreto n. ${ }^{\circ}$ 18.542/1928, dá conta o relato de sua biografia no sítio eletrônico do Supremo Tribunal Federal (cf. www.stf.jus.br/portal/ministro).
} 
As alterações decorrentes das sugestões de Philadelpho AzEvedo representaram grande evolução na disciplina da fraude de execução, colocando em paralelismo quase perfeito a legislação processual e registrária. Considerando os casos de fraude de execução previstos originalmente nos $\S \S 1^{\circ}$ a $3^{\circ}$ do artigo $494^{\circ}$ do Regulamento 737 - que, como visto, ainda se mantinham com poucas alterações na legislação federal e nos códigos estaduais -, pode-se dizer que, em relação aos bens imóveis, as hipóteses dos $\S \S 1^{\circ}$ e $2^{\circ}$ estavam totalmente cobertas pela possibilidade de inscrição no registro imobiliário e, da hipótese do $\S 3^{\circ}$, o novo regime da hipoteca judiciária deixava a descoberto apenas as alienações realizadas até a sentença de primeiro grau e nas ações relativas a títulos extrajudiciais até a penhora.

Foi já à luz dessas alterações que adveio, finalmente, em 1930, o Código do Processo Civil e Comercial do Estado de São Paulo, promulgado pela Lei n. ${ }^{\circ} 2.421$, de 14 de janeiro daquele ano e o último dos códigos estaduais objeto de nossa análise.

Muito provavelmente em função da época de sua promulgação, o código paulista possuía a mais completa disciplina sobre a fraude de execução, colocando-se em harmonia tanto com as regras do Código Civil, quanto com as do Decreto Legislativo n. ${ }^{\circ}$ 4.827/1924 e do Decreto n. ${ }^{\circ}$ 18.542/1928, como se verifica:

Art. 949. Póde a execução versar sobre bens de terceiro ou existentes em poder de terceiro:

I - Quando alienados ou sujeitos a ônus ou encargos em fraude de execução, ou por ato nullo (Codigo Civil, arts. 145 e 146); (...)

Art. 950. Verifica-se a fraude de execução:

I- Quando o acto é precedido de arresto, seqüestro, penhora ou citação para acção real ou pessoal, reipersecutória, inscriptos, em se tratando de immovel, na forma do decreto legislativo n. ${ }^{\circ} 4.827$, de 1924;

II- Quando é praticado na imminencia da penhora, por haver execução apparelhada ou título que dê direito à acção executiva, protestado por falta de pagamento;

III- Quando o adquirente dos bens tem razão para saber da pendência de demanda e da inexistência de outros bens do devedor, sufficientes, livres e susceptíveis de penhora;

Parágrapho único - Tratando-se de título de crédito, direitos ou acções, reputam-se fraudatórios os pagamentos, remissões e cessões effectuados depois da intimação da penhora. 
Art. 951. Não se procederá a penhora, aprehensão ou immissão de posse sobre bens de terceiro (art. 949, I, II e IV), sem pedido fundamentado do exequente, despacho do juiz e caução à reparação do damno."181

Logo de início, depreende-se que, em seu artigo 949, I, o código paulista colocava a fraude de execução ao lado das nulidades previstas no Código Civil de 1916, não exigindo nesses casos que fosse proferida sentença em ação própria para que a execução alcançasse bens pertencentes a terceiro, como ocorria nos casos de fraude contra credores, incapacidade relativa do agente, erro, dolo, coação e simulação. ${ }^{182}$ Tal disposição reflete o entendimento, predominante na época, de que, nos casos de fraude de execução, o ato era nulo, enquanto, na fraude contra credores, o ato era apenas anulável.

Quanto à disciplina das hipóteses da fraude de execução, verifica-se que o código paulista uniu os casos antes previstos no $\S 1^{\circ}$ e na primeira parte do $\S 2^{\circ}$ do artigo $494^{\circ}$ do Regulamento 737 , estabelecendo que a fraude estaria configurada a partir da citação do réu em ação real ou pessoal reipersecutória ou a partir da realização de arresto, sequestro ou penhora. No entanto, tratando-se de bem imóvel, em atenção ao artigo $5^{\circ}$ do Decreto Legislativo n. ${ }^{\circ} 4.827 / 1924$ e aos artigos 266 e 267 do Decreto n. ${ }^{\circ} 18.542 / 1928$, o código paulista exigia, ainda, a prévia inscrição desses atos no registro imobiliário para a configuração da fraude de execução.

Em outras palavras, em relação aos bens imóveis, o legislador paulista condicionou a configuração da fraude de execução à inscrição da citação ou da constrição, conforme o caso, no registro imobiliário (cf. art. 950, I).

Em seu inciso II, o artigo 950 esclarecia que se entendia por "iminente" a penhora nas hipóteses de haver execução aparelhada ou título extrajudicial protestado por falta de pagamento, eliminando, como feito em outros códigos estaduais, as dúvidas que a expressão "proximamente à penhora” gerava no regime do Regulamento 737.

O inciso III do referido artigo 950 manteve a mesma hipótese prevista no $\S 3^{\circ}$ do artigo $494^{\circ}$ do Regulamento 737 . Assim, também exigia o elemento subjetivo

\footnotetext{
${ }^{181}$ MALHEIROS, Aristides. Codigo do Processo Civil e Commercial do Est. de São Paulo. São Paulo: Ed. Revista dos Tribunais, 1930. p. 134-136.

${ }^{182} \mathrm{Em}$ tais hipóteses, era necessária a prévia anulação do ato por sentença, como se depreende do inciso II do referido artigo 949: "quando houver sentença que annulle a alienação ou a constituição de onus ou encargos, por acto simplesmente annullavel (Codigo Civil, arts. 147 e 152)."
} 
apenas para a configuração desse caso de fraude de execução, devendo ser provada a má-fé do terceiro decorrente da razão que este teria para saber da pendência da ação e da "inexistência de outros bens do devedor, suficientes, livres e suscetíveis de penhora". ${ }^{183}$

Finalmente, no parágrafo único do artigo 950, o código previu que também configuravam fraude de execução os pagamentos, remissões e cessões de títulos de crédito, direitos ou ações do devedor após intimação da penhora, sem também exigir prova do elemento subjetivo.

Já no artigo 951, o código processual paulista estabelecia que não se procederia à constrição de bens de terceiro sem pedido do credor, decisão do juiz e caução para eventual reparação de dano causado ao terceiro. ${ }^{184}$

Ao lado das alterações já analisadas, outra relevante contribuição do código paulista para a aplicação do instituto da fraude de execução foi a implementação de melhorias no tão criticado sistema de pesquisa nos cartórios distribuidores.

Instituiu assim o legislador paulista a obrigatoriedade do registro nesses cartórios de todos os processos em curso e a criação de dois livros especiais para consulta, organizados em ordem alfabética pelo nome das partes, em que constavam o objeto da causa, seu número e a página no livro de distribuição da comarca: um local, disponível em cada comarca com as informações dos feitos nela em curso, e outro geral, disponível na Secretaria do Tribunal de Justiça e atualizado mensalmente com as informações enviadas por todas as comarcas do Estado. Era o que previam os artigos 118 e 119:

"Art. 118. Nenhum processo, embora vindo de outro juizo, terá andamento sem que seja distribuido e registrado.

\footnotetext{
${ }^{183}$ Nessa expressão final, fica clara a redação mais técnica da norma do código paulista em relação à anterior (que em seu lugar mencionava: "outros bens não tinha o executado por onde pudesse pagar") e, até mesmo, em relação à prevista no artigo 593, II, do Código de Processo Civil atual, pois o termo "insolvência" utilizado nela é impreciso para representar a situação de frustração da atividade executiva.

${ }^{184}$ Exaltando as vantagens da disciplina do código paulista em relação à adotada pelo Código de Processo Civil de 1973, comenta Nelson Altemani que "o mais notável entretanto no Código paulista, foi a disposição do artigo 951, segundo a qual a execução sobre bens de terceiro, ou existentes em mão de terceiro, somente se realizaria mediante pedido fundamentado do exequente, despacho do juiz e caução à reparação do dano. É realmente elevado o alcance da norma, a prever a solução de problemas que, no atual Código, dependem de especial esforço de interpretação. Pois, se o ato é ineficaz, independentemente de declaração judicial nesse sentido, é bem de ver que somente o credor (exequente) tem condições de apontar ao juiz a ocorrência da fraude de execução; ao juiz se defere o poder de mandar que sobre os bens indicados pelo credor se faça a execução; finalmente, ao credor se atribui a responsabilidade pela afirmação da ocorrência de fraude, exigindo-se-lhe que preste caução." (ALTEMANI, Nelson. Fraude de execução. RJTJSP, São Paulo, n. 40, p. 23, maio/jun. 1976).
} 
$\S$ único. Em caso de urgencia, poderá a parte, quando houver mais de um juiz, com jurisdicção cumulativa, requerer a qualquer delles, e esse designará o serventuário. $\mathrm{O}$ requerente ou o escrivão designado levará o feito ao distribuidor, dentro de tres dias, para o registro e anotações necessarias, sob pena de ser imposta a cada um delles pelo juiz da causa a multa de cincoenta a duzentos mil réis.

Art. 119. O distribuidor organizará o registro dos feitos em livro especial, por ordem alphabetica, indicando por extenso os nomes das partes e o objecto da causa, com referencia ao numero e à pagina do livro de distribuição.

$\S 1^{\circ}$ A requerimento de qualquer das partes, cancellar-se-á o registro do feito que, em trinta dias, não der entrada no cartorio do escrivão, ou cuja distribuição tenha ficado sem effeito.

$\S 2^{\circ}$ Até o dia dez de cada mez, o distribuidor enviará à Secretaria do Tribunal de Justiça para organização do registro geral, a relação dos feitos registrados e cancellados no mez anterior." ${ }^{185}$

Com a instituição da obrigatoriedade do registro, a criação de livros dos registros locais e do registro geral dos feitos em curso em todo o Estado e a organização de sistema de busca pelo nome das partes, o código processual paulista deu grandes passos em direção à solução da falibilidade das buscas nos distribuidores que, como já mencionado, tornava dificultosa a obtenção de informações sobre ações pendentes em face do alienante e, como consequência, iníqua a situação gerada pela presunção absoluta da possibilidade de ciência do terceiro existente no regime do Regulamento 737.

Comentando o histórico das discussões para a criação desse último dispositivo no projeto do código paulista, JORGE AMERICANO afirma que a sugestão "seria de autoria do Snr. Alcantara Machado, que o apresentou fundado na necessidade da creação de um registro local de feitos em cada comarca, e de um registro geral, comprehendendo todo o Estado, na Secretaria do Tribunal de Justiça. (...) Pode parecer à primeira vista, accrescentou o Snr Alcantara Machado, que a distribuição, como se faz actualmente, dispensa o registro. Não é assim; as buscas, pelo systema actual, são dispendiosas e difficeis. Além disso, o individuo, cuja situação a parte procura conhecer, pode figurar activa e passivamente em juizo differente do de seu domicilio. Instituido o registro em cada comarca e estabelecido que mensalmente os distribuidores enviem à secretaria do Tribunal uma relação completa de todos os feitos registrados no mez anterior,

${ }^{185}$ MALHEIROS, Aristides. Codigo do Processo Civil e Commercial do Est. de São Paulo, cit., p. 134-136. 
conseguir-se-ão duas grandes vantagens: primeira - facilitar as buscas; segunda - fornecer preciosos elementos para a estatistica judiciaria." 186

Como se observa, em seu sistema, o código paulista solucionou os principais problemas que acometiam o instituto no regime do Regulamento 737.

Assim, em relação aos bens imóveis, previu que a caracterização da fraude de execução dependeria da inscrição no registro imobiliário da citação do réu na ação real ou reipersecutória ou da penhora, em sintonia ao que dispunha a legislação registrária então em vigor.

Quanto aos bens móveis, o código previa quatro situações. Em primeiro lugar, em se tratando de ação real ou reipersecutória, bastava a citação do réu para que a alienação do bem fosse considerada em fraude de execução (art. 950, I). Em segundo lugar, tratando-se de obrigação constante de título extrajudicial que ensejasse ação executiva, estava configurada a fraude de execução desde o seu protesto por falta de pagamento, ato que, como já visto, gozava de certa publicidade (art. 950, II). Em terceiro lugar, tratando-se de obrigação sujeita a reconhecimento por sentença (título judicial), a fraude de execução estava configurada se a alienação ocorresse depois da constrição do bem ou, ainda, depois que o credor já dispusesse de execução aparelhada (art. 950, I ou II). Finalmente, em quarto lugar, sendo a ação condenatória e o credor ainda não dispusesse de execução aparelhada, este deveria comprovar que o terceiro tinha razão para saber da pendência da ação e da inexistência de outros bens do devedor sujeitos à penhora (art. 950, III).

Excetuada a hipótese do título extrajudicial protestado, em que ainda não havia processo em curso, em todas as outras, a organização dos registros dos distribuidores na forma dos artigos 118 e 119 do código paulista facilitava a consulta pelos terceiros, conferindo maior legitimidade à presunção absoluta feita pelo legislador nos incisos I e II do artigo 950 e facilitando a prova da possibilidade de conhecimento do terceiro, exigida no inciso III. De fato, estando registrada a ação - o que, como visto, era obrigatório -, se o terceiro fizesse a consulta pelo nome do alienante nos livros de registro local e geral, teria como saber de sua pendência, ainda que ela estivesse em curso em comarca distinta da de seu domicílio ou daquela em que o bem estava situado, salvo se fora do Estado.

${ }^{186}$ AMERICANO, Jorge. Commentarios ao Codigo do Processo Civil e Commercial do Estado de São Paulo. 
Observa-se que a preocupação do legislador paulista era a de atrelar a configuração das hipóteses de fraude de execução com a efetiva possibilidade de ciência pelo terceiro das circunstâncias em que estava adquirindo o bem, reportando-se, sempre que possível, aos registros públicos em que essas informações estariam disponíveis. ${ }^{187}$

Contudo, as regras do código paulista sobre a fraude de execução vigoraram por menos de uma década, já que, em razão de a Constituição de 1934 ter devolvido à União Federal a competência exclusiva para legislar sobre processo, adveio, em 1939, o primeiro Código de Processo Civil nacional.

Terminada a análise desse segundo período da história da fraude de execução, pode-se concluir que a legislação processual da época manteve quase inalteradas as três hipóteses de fraude de execução previstas no Regulamento 737 - pendência de ação real ou reipersecutória sobre o bem; existência de penhora já realizada ou iminente; e existência de razão para que o terceiro soubesse da pendência de ação e da insuficiência do patrimônio do devedor para satisfazer o crédito cobrado.

Da mesma forma, o elemento subjetivo apenas se fazia relevante, para a configuração dessa terceira hipótese de fraude de execução, entendendo-se que ele consistia na má-fé apenas do terceiro, decorrente da existência de razão para saber da ação pendente e da insuficiência dos outros bens existentes no patrimônio do devedor.

Ainda nesse período, houve considerável aumento da preocupação com o oferecimento de meios efetivos para que os terceiros pudessem ter ciência de que suas aquisições não estariam sendo feitas em fraude de execução. Assim, a legislação registrária evoluiu, passando a permitir a inscrição no registro imobiliário não só da hipoteca

\footnotetext{
São Paulo: Saraiva, 1934. v. 1, p. 415.

${ }^{187}$ Essa preocupação vinha desde a elaboração do projeto desse código, como se extrai da norma projetada que deu origem ao artigo 950 do texto definitivo:

"Art. 1.325. Verifica-se a fraude de execução, quando o acto é precedido:

I- De arresto, sequestro, penhora ou citação para a acção real ou pessoal reipersecutória, inscriptos nos termos do decreto legislativo federal n. 4.827, de 7 de feveriro de 1924.

II- De protesto, por falta de pagamento, do titulo em que se fundar a acção, sendo ella executiva, e tendo sido o protesto publicado.

III- Do protesto, interpellação ou notificação ao publico, em geral (art. $496 \mathrm{n}$. I), sobre:

a) a existencia de algum dos actos mencionados no n. I, tratando-se de cousas moveis;

b) a imminencia da penhora, por haver execução apparelhada;

c) a pendencia da demanda, e a circunstancia de não ter o devedor outros bens sufficientes, livres e susceptiveis de penhora.

$\S$ Unico - Se o terceiro contractante tiver tido sciencia de qualquer dos factos mencionados neste artigo, será o acto havido por fraudulento embora não inscripto ou publicado." (Projecto do Codigo do Processo Civil e Commercial do Estado de São Paulo, $6^{\circ}$ vol., São Paulo: Publicação Official, 1927, p. 467).
} 
judiciária, mas também da penhora e da citação de ações reais e pessoais reipersecutórias de imóveis, estabelecendo correspondência com as hipóteses de fraude de execução antes previstas nos $\S \S 1^{\circ}$ e $2^{\circ}$ do artigo $494^{\circ}$ do Regulamento 737. Além disso, também a hipoteca judiciária foi ampliada, podendo ser inscrita já a partir da sentença de primeiro grau, independentemente de estar sujeita a recurso ou liquidação.

Por fim, a própria legislação processual evoluiu no mesmo sentido, não só fazendo menção à necessidade de a pendência da ação ou da constrição do bem constar nos registros públicos para a configuração da fraude de execução, como também organizando o sistema de buscas nos distribuidores forenses, outra importante fonte de informações para que os terceiros pudessem ter ciência da pendência da ação contra o devedor.

\section{3- Terceiro período (1939-1973): o Código de Processo Civil de 1939 e o rompimento do paralelismo conquistado no período anterior}

A Constituição Federal de 1934 outorgou novamente à União a competência para legislar sobre processo civil, tendo previsto no artigo 11 de suas disposições transitórias a nomeação de uma comissão de três juristas, composta por dois ministros do Supremo Tribunal Federal e um advogado, para organizar o projeto do Código de Processo Civil e Comercial que passaria a valer em todo o território nacional, substituindo os códigos estaduais e o Decreto n. ${ }^{\circ} 3.084 / 1898$ que então regulava o processo nas causas federais.

A comissão nomeada pelo governo federal foi composta pelos Ministros ARHur Ribeiro de Oliveira e CARvalho Mourão e pelo advogado Levi CARNeIRo, apresentando anteprojeto com a seguinte disciplina sobre a fraude de execução:

“Art. __. É competente a execução contra a parte vencida e seus sucessores ou contra qualquer que della tenha recebido a causa ou a quem o julgado prejudique, como: (...)

3) o comprador ou possuidor de bens hypothecados, segurados ou alienados em fraude de execução; (...)

Art. . Os bens do executado consideram-se alienados em fraude de execução: 
1) quando são litigiosos ou sobre elles pende demanda;

2) quando a alienação é feita depois da penhora ou proximamente a ella, entendendo-se a penhora por imminente, quando ha execução apparelhada ou título que dê acção executiva, protestado por falta de pagamento;

3) quando o adquirente tinha razão de saber que pendia demanda e outros bens não possuía o alienante por onde pudesse pagar, sufficientes e livres.

$\S 1^{\circ}$ Tratando-se de título de crédito, reputam-se fraudatorios os pagamentos, remissões e cessões efectuados depois da intimação da penhora.

$\S 2^{\circ}$ Fora esses casos, para que a execução possa recahir sobre bens alienados, devem ser annullados, mediante acção competente, os actos de alienação em fraude do credor.

$\S 3^{\circ}$ Compete ao exequente o direito de prosseguir na execução da sentença contra os adquirentes dos bens do condemnado, dependendo, porém, para isso, de inscripção e especialização."188

Tendo havido divergências na comissão, o trabalho de elaboração do anteprojeto passou às mãos de PEDRo BATISTA MARTINS que, contando com a revisão de Francisco CAMPOS, então Ministro da Justiça, Guilherme Estellita e AbGaR ReNault, apresentou o texto que deu origem ao Código de Processo Civil de 1939.

O Código de Processo Civil de 1939, Decreto-Lei n. ${ }^{\circ}$ 1.608, de 18 de setembro de 1939, tratava especificamente da fraude de execução em seus artigos 888, V, e 895, que assim dispunham:

“Art. 888. Ficarão sujeitos à execução os bens: (...)

V - alienados ou hipotecados em fraude de execução.

Art. 895. A alienação de bens considerar-se-á em fraude de execução:

I- quando sobre eles for movida ação real ou reipersecutória;

II- quando ao tempo da alienação, já pendia contra o alienante demanda capaz de alterar-lhe o patrimônio, reduzindo-o à insolvência;

\footnotetext{
${ }^{188}$ OLIVEIRA, Arthur Ribeiro de. Commentarios do Projeto do Codigo do Processo Civil e Commercial da República dos Estados Unidos do Brasil. Rio de Janeiro: Imprensa Official, 1935. p. 33-34. Como se pode notar, a redação dos dispositivos assemelhava-se à contida no Código do Processo Civil de Minas Gerais, com algumas adições aparentemente extraídas do código processual paulista.
} 


\begin{abstract}
III- quando transcrita a alienação depois de decretada a falência;
IV- nos demais casos expressos em lei."
\end{abstract}

Como se observa, em comparação com a legislação processual anterior, o código de 1939 fez sensíveis modificações na disciplina da fraude de execução, quebrando o paralelismo com a legislação registrária alcançado na década de 1920.

Foram incluídas duas novas hipóteses de fraude de execução nos incisos III e IV do artigo 895 código de 1939. Previam esses dispositivos que também seriam consideradas em fraude de execução a alienação realizada após a decretação da falência e outros "casos expressos em lei", tal qual o inciso II do artigo 593 do CPC atual.

Como já foi mencionado no item 2.3.3.2, supra, a hipótese do inciso III tratava de matéria estranha ao próprio código, sobrepondo-se a dispositivo da legislação de falências em vigor, o que ensejou fundadas críticas da doutrina. ${ }^{189}$ Quanto à exigência da presença do elemento subjetivo, observa-se que tanto a norma desse inciso III quanto o dispositivo a ela correspondente na legislação falimentar ${ }^{190}$ deixavam claro que tal elemento era absolutamente irrelevante para a configuração da fraude de execução.

Já o inciso IV aludia, genericamente, a outros "casos expressos em lei”, não havendo consenso na doutrina sobre quais casos seriam esses. Alguns autores, como

\footnotetext{
${ }^{189}$ Nesse sentido, Luiz Antonio da Costa Carvalho afirmava que "no art. $1^{\text {o }}$ o Código exclue expressamente da sua esféra de ação, do campo de sua autoridade, todos os processos regulados por lei especial figurando dentre outros processos o de falência que é, por enquanto, regulado pelo Decreto n. ${ }^{\circ} 5.746$ de 9 de dezembro de 1929. Por êsse motivo, que é relevante, não se compreende a razão porque o Código faz referência no n. ${ }^{\circ}$ III do artigo 895 à alienação feita depois de decretada a falência tanto mais quanto a lei 5.746 faz referência expressa ao assunto no art. 55 n. ${ }^{\circ}$ 7." (CARVALHO, Luiz Antonio da Costa. $O$ Espírito do Código de Processo Civil. Rio de Janeiro: Labor, 1941. p. 331). Também comungava desse entendimento, entre outros, Ataliba Vianna: "não se explica a razão porque, no n. ${ }^{\circ}$ III do artigo 895 teria o Codigo feito alusão a caso de fraude concernente à falencia, instituto que é regido por lei especial. Não havendo contemplado entre os processos que regulou, o de falencias, não se justifica haja o Codigo considerado caso de fraude peculiar à falencia. (...) É uma redundância ociosa, pois a lei de falencias, no art. 55 n. 7 já consignava a hipotese." (VIANNA, Ataliba. Inovações e obscuridades do Codigo do Processo Civil e Comercial brasileiro. São Paulo: Martins, 1940. p. 181).

${ }^{190}$ Decreto n. ${ }^{\circ}$ 5.746, de 9 de dezembro de 1929:

"Art. 55. Não produzirão effeitos relativamente à massa, tenha ou não o contractante conhecimento do estado economico de devedor, seja ou não intenção deste fraudar os credores: (...)

$7^{\circ}$ as inscripções de hypothecas e as transcripções de onus reaes e de transmissões inter-vivos, por titulo oneroso ou gratuito, de immoveis susceptiveis de hypotheca, realizadas após a decretação do sequestro ou a declaração da fallencia. (...)"
} 
De PlÁCIDO E Silva, entendiam que seriam “justamente aqueles em que o devedor pratica actos em fraude contra credor, segundo institui a Lei Civil nos arts. 106 a 113". ${ }^{191}$

Outros, como Jorge AmericAno, entendiam que tais "casos expressos em lei" abrangiam todas as hipóteses previstas na legislação material em que a execução poderia atingir bens de terceiros, como os casos de nulidade do artigo 145 do Código Civil; os casos de anulabilidade do artigo 147 do mesmo código, após o seu reconhecimento por sentença; os casos de direito de sequela do artigo $816, \S \S 2^{\circ}$ e $3^{\circ}$, e 824 do mesmo código; os casos de responsabilidade de bens dos sócios, previstos nos artigos 1.396, 1.407 do Código Civil e 350 do Código Comercial; e os casos do fiador, previstos nos artigos 1.491 do Código Civil e 261 do Código Comercial, dizendo, por fim, que nesse inciso IV, "a lei processual não fez mais que reportar-se à lei substantiva, onde estão definidos os casos em que a execução afeta a propriedade alheia."192

Tais entendimentos, contudo, alargavam demais os limites da fraude de execução, comprometendo seriamente a identificação do instituto e, consequentemente, dificultando sua interpretação. Ora, se as hipóteses de fraude de execução se confundiam com as de nulidade, anulabilidade, sequela, responsabilidade de bens dos sócios e do fiador, o instituto era tudo e nada ao mesmo tempo, não se podendo definir quais seriam suas características específicas para isolá-lo dos demais. É válida, portanto, a observação de Luiz ANTONiO DA COSTA CARVALHO que, notando a vagueza da norma desse inciso IV, apresentava crítica no sentido de que "os casos de alienação em fraude da execução devam ser certos e determinados para afastar a possibilidade das cavilações jurisprudenciais, sempre prejudiciais aos interêsses dos que litigam."

Posição mais coerente era a defendida por AMÍLCAR DE CASTRO, que indicava entre os casos abrangidos por esse inciso IV os previstos nos artigos 280 e 281 do Decreto n. ${ }^{\circ} 4.857$, de 9 de novembro de 1939; no artigo $2^{\circ}$ do Decreto n. ${ }^{\circ} 22.866$, de 28 de junho de 1933; e no artigo 939, § 2º do próprio Código de Processo Civil, uma vez que faziam referência expressa à fraude de execução. ${ }^{194}$

\footnotetext{
${ }^{191}$ SILVA, De Placido e. Comentários ao Código de Processo Civil. 3. ed. São Paulo: Guaíra, 1948. v. 4. p. 1.705.

${ }^{192}$ AMERICANO, Jorge. Comentários ao Código do Processo Civil do Brasil. São Paulo: Saraiva, 1943. v. 4 , p. 169-171.

${ }^{193}$ CARVALHO, Luiz Antonio da Costa. O Espírito do Código de Processo Civil, cit., p. 332.

${ }^{194}$ Cf. CASTRO, Amílcar de. Comentários ao Código de Processo Civil, cit., v. 10, p. 79.
} 
Realmente, todas essas normas faziam menção expressa à fraude. No entanto, uma correção se faz necessária. Trata-se do fato de que, à diferença dos outros dois dispositivos citados pelo autor, os artigos 280 e 281 do Decreto n. ${ }^{\circ} 4.857 / 1939$ não tratavam verdadeiramente de outros "casos" de fraude de execução, limitando-se a dispor o seguinte:

“Art. 280. A inscrição da penhora faz prova quanto à fraude de qualquer transação posterior.

Art. 281. Serão inscritas, no livro 4 , as ações reais, ou pessoais reipersecutórias, inclusive possessórias, quando for o caso, e as de retificação de registro, pelas certidões das citações, com os mesmos requisitos dos arts. 250 e 279 no que for aplicável, averbando-se as decisões, recursos e seus efeitos e ficando, desde logo, considerados os bens como litigiosos para o efeito de apreciação de fraude de posteriores alienações."

Como se observa, esses dois dispositivos, juntamente com o artigo 274 do mesmo Decreto n. ${ }^{\circ} 4.857 / 1939,{ }^{195}$ repetiam, praticamente com as mesmas palavras, os já analisados artigos 258, 266 e 267 do Decreto n. ${ }^{\circ}$ 18.542/1928 que tratavam da inscrição, no registro imobiliário, da hipoteca judiciária, da penhora e das citações em ações reais e reipersecutórias sobre bens imóveis.

Como já vimos no item anterior, foram precisamente essas mesmas normas que, partindo das sugestões de PHILAdELPHO AzEVEDO, alinharam a legislação registrária com a disciplina da fraude de execução existente no Regulamento 737 e nas legislação processual revogada pelo código de 1939. Assim, tais dispositivos não criavam outras hipóteses de fraude de execução, mas, ao contrário, apenas forneciam disciplina acessória às hipóteses já existentes na legislação processual, de modo que, com a

\footnotetext{
${ }^{195}$ Que dispunha sobre a hipoteca judiciária nos seguintes termos:

"Art. 274. Considerar-se-á, também, especializada, e, apenas dependente de inscrição, a hipoteca judiciária, mediante mandado ou carta de sentença, quando esta for líquida, quanto aos bens existentes em posse do condenado, ou alienados, em fraude de execução. Em caso contrário, apurar-se-á, provisoriamente, o valor da responsabilidade, sem prejuízo do processo de liquidação.

$\S 1^{\circ}$ Mesmo a sentença recorrida, qualquer que seja o seu efeito, autorizará a inscrição, com caráter condicional, fazendo-se observação a respeito.

$\S 2^{\circ} \mathrm{O}$ credor indicará, em petição, os imóveis sobre os quais deve recair a inscrição, com os requisitos necessários, ficando salvo ao devedor requerer ao juiz competente a redução ou substituição dos imóveis apontados."

Quanto à hipoteca judiciária, o Código de Processo Civil de 1939 possuía apenas singela menção em seu artigo 284, que assim dispunha: "Art. 284. Quando, em virtude de sentença, recair sobre os bens do condenado hipoteca judiciária, a respectiva inscrição será ordenada pelo juiz, mediante mandado, na forma da lei civil."
} 
publicidade decorrente da inscrição de atos no registro imobiliário, os terceiros efetivamente teriam condições de saber em que circunstâncias estavam adquirindo o bem.

Para comprovar esse fato, basta observar que a norma do artigo 281 do Decreto n. ${ }^{\circ}$ 4.857/1939 ligava-se à hipótese do inciso I do artigo 895 do Código de Processo Civil de 1939, tal qual o artigo 267 do Decreto n. ${ }^{\circ}$ 18.542/1928 ligava-se, por exemplo, ao inciso 1 do artigo 1.290 do Código de Processo Civil de Minas Gerais. A única diferença - como veremos mais adiante - é que o código de 1939, ao suprimir a hipótese de fraude de execução decorrente da alienação do bem penhorado, quebrou o paralelismo com a legislação registrária, deixando o artigo 280 do Decreto n. ${ }^{\circ}$ 4.857/1939 sem se ligar a qualquer dispositivo da lei processual, como acontecia com o artigo 266 do Decreto n. ${ }^{\circ}$ 18.542/1928 e, por exemplo, o inciso 2 do artigo 1.290 do código mineiro. ${ }^{196}$

Já o artigo $2^{\circ}$ do Decreto n. $^{\circ} 22.866 / 33$ efetivamente criava um novo caso de fraude de execução ao assim dispor:

"Art. $2^{\circ}$ Consideram-se feitas em fraude da Fazenda Pública as alienações ou seu começo, realizadas pelo contribuinte em debito."

Nessa hipótese, resta claro, o elemento subjetivo é de todo irrelevante, bastando que a alienação tivesse ocorrido após o contribuinte estar em débito com a Fazenda Pública para que a fraude de execução estivesse configurada. ${ }^{197}$

Da mesma forma, o artigo 939, § 2º do Código de Processo Civil também tratava de outra hipótese de fraude de execução, decorrente da transferência de título de crédito penhorado, ${ }^{198}$ assim dispondo:

\footnotetext{
"Art. 939. Tratando-se de letra de câmbio, nota promissória ou outro título de crédito, considerar-se-á feita a penhora, mediante notificação ao devedor para não pagar, e aos terceiros interessados, por edital com o prazo de quinze (15) dias, para ciência da penhora. (...)
}

\footnotetext{
196 Verifica-se aqui o início do distanciamento entre a legislação processual e registrária, tal como representado graficamente na Figura 2 do Apêndice 3 desta tese.

${ }^{197} \mathrm{O}$ dispositivo sequer exigia o ajuizamento da execução fiscal, similarmente ao que atualmente prevê o artigo 185 do CTN, após a alteração da Lei Complementar n. ${ }^{\circ}$ 118, de 2005, analisado no item 2.3.3.3, supra.

${ }^{198}$ Hipótese semelhante existia, conforme visto anteriormente, no parágrafo único do artigo 950 do Código de Processo Civil e Comercial do Estado de São Paulo.
} 
$\S 2^{\circ}$ A transferência do titulo, feita após o prazo do edital, considerar-se-á em fraude de execução."

Quanto ao elemento subjetivo, também era irrelevante neste caso, bastando a publicidade ficta decorrente do edital. A transferência do título só seria considerada em fraude de execução após o prazo do edital para a ciência de terceiros.

Além dessas duas hipóteses dos incisos III e IV do artigo 895, o código de 1939 também trouxe importantes alterações nos casos previstos nos incisos I e II, que corresponderiam àqueles já existentes na legislação anterior.

Quanto ao inciso I, observa-se que nele foi mantida a hipótese de fraude decorrente de alienação de bens litigiosos. Contudo, diferentemente do código processual paulista, o diploma de 1939 não fazia referência aos dispositivos da legislação registrária, que, como visto, condicionavam a configuração da litigiosidade dos bens imóveis, para efeito de caracterização da fraude de execução, à prévia inscrição, no registro de imóveis, da citação do réu nas ações reais e reipersecutórias (cf. art. 281 do Decreto n. ${ }^{\circ}$ 4.857/1939).

Embora a norma do inciso I do artigo 895 nada previsse nesse sentido, a maior parte da doutrina, interpretando conjuntamente esse dispositivo com o art. 281 do Decreto n. ${ }^{\circ} 4.857 / 1939$, passou a exigir tal inscrição ou, ausente esta, condicionava a configuração da fraude de execução à comprovação da ciência do terceiro. ${ }^{199}$

A maior alteração, contudo, constava do inciso II do art. 895 do código de 1939, que estabelecia, simplesmente, considerar em fraude de execução a alienação feita "quando, ao tempo da alienação, já pendia contra o alienante demanda capaz de alterar-lhe o patrimônio, reduzindo-o à insolvência”.

A redação adotada pelo inciso II não correspondia a nenhum dispositivo da legislação anterior, dando ensejo a duas grandes discussões. A primeira delas dizia

\footnotetext{
${ }^{199}$ Nesse sentido, além de Alcides de Mendonça Lima, já citado, cf., entre outros, J. M. de Carvalho Santos: "no Registro de Immoveis deverá ser feita a inscripção das acções reaes ou pessoaes reipersecutorias relativas a immoveis, afim de terem effeito contra terceiros. Donde a conclusão muito logica: essa inscripção é essencial para a invalidação do acto fraudulento, a não ser que se prove ter o terceiro contractante, por outro qualquer meio, tido sciencia do inicio da demanda. Nem se conceberia que fosse de outro modo, pois o legislador não exigiria a inscripção da citação, para, afinal, não lhe emprestar nenhum effeito." (SANTOS, J. M. de Carvalho. Código de Processo Civil interpretado. Rio de Janeiro: Freitas Bastos, 1941. v. 10, p. 38).
} 
respeito à supressão da hipótese de fraude de execução decorrente da alienação de bem já penhorado ou na iminência de sê-lo, originalmente prevista no $\S 2^{\circ}$ do artigo $494^{\circ}$ do Regulamento 737.

Tendo em vista que o inciso II do artigo 895 nada dispunha sobre a penhora, tanto a doutrina, ${ }^{200}$ quanto a maior parte da jurisprudência da época ${ }^{201}$ entendiam que o código de 1939 havia suprimido essa hipótese de fraude de execução, quebrando, nesse ponto, o paralelismo com o decreto registrário, que em seu artigo 280 ainda previa que "a inscrição da penhora faz prova quanto à fraude de qualquer transação posterior".

A segunda alteração que o legislador de 1939 realizou nesse mesmo inciso II, foi a supressão do elemento subjetivo como requisito para a configuração dessa hipótese de fraude de execução.

A supressão desse elemento fica clara ao se confrontar a expressão "quando o adquirente tinha razão de saber que pendia demanda contra o devedor e não possuía este outros bens para o pagamento", ${ }^{202}$ existente, com alguma variação redacional, desde o $\S 3^{\circ}$ do artigo $494^{\circ}$ do Regulamento 737 , com a que a substituiu no inciso II do artigo 895 do código de 1939: "quando ao tempo da alienação, já pendida contra o alienante demanda capaz de alterar-lhe o patrimônio, reduzindo-o à insolvência”.

\footnotetext{
${ }^{200}$ Cf. José Frederico Marques: "a alienação feita na iminência de penhora em ação executiva ou após o protesto de título cambiário não constitui caso de venda in fraudem executionis. (...) A venda de bem penhorado, portanto, não é caso de fraude de execução." (MARQUES, José Frederico. Instituições de direito processual civil. 3. ed. Rio de Janeiro: Forense, 1971. v. 5, p. 298-299). Também nesse sentido, J. M. de Carvalho Santos: "já não se considera em fraude de execução a alienação feita proximamente à penhora" (SANTOS, J. M. de Carvalho. Código de Processo Civil interpretado, cit., v. 10, p. 38) e Hahnemann Guimarães: "não se dispensa mais a ação pauliana, no caso de alienação feita depois da penhora" (GUIMARÃES, Hahnemann. Fraude de execução. Revista de Jurisprudência Brasileira, Rio de Janeiro, v. 82, p. 124, jan./fev. de 1949).

201 "Na previsão do Cód. de Proc. Civil não mais se encontra o caso do n. ${ }^{\circ} 2$ do art. 494 do reg. n. ${ }^{\circ} 737$, de 25 de novembro de 1850. Fora das hipóteses enunciadas no art. 895, os atos de alienação em fraude de credor sómente podem ser anulados por ação revocatória ou pauliana (...) Fraude em execução é hoje a alienação dos bens na pendência de uma ação e não quando a ação esteja iminente, ou próxima a penhora." (STF, RE 10.220, rel. Min. Lafayette de Andrada, j. 10.09.47, in Revista Forense n..$^{\circ} 110$, março de 1947, p. 77 e ss.); "Não existe mais a figura da fraude de execução por alienação próximamente à penhora ou depois de execução aparelhada." (TJMG, Rel. Des. Amílcar de Castro, Rec. Rev. 137, j. 07.09.45, in ARMANDO, Nicanor N. Fraude aos credores e à execução perante os tribunais. Belo Horizonte: UFMG, 1967. p. 28); "A lei dispõe que a fraude de execução verifica-se quando a alienação de bens é feita na pendência de uma demanda, a dizer, quando a ação já tenha sido proposta e que o devedor se torne insolvente. (...) Não se indaga, hoje, se o ato alienativo deu-se na iminência da penhora, ou se existe execução aparelhada, como no direito anterior." (TJSP, 6 ${ }^{\text {a }}$ Câm. Civil, Apel. 47.727, rel. Des. Justino Pinheiro, j. 02.06.50, in RT 187/725).

${ }^{202}$ Artigo 969, IV, do Código de Processo Civil e Comercial para o Distrito Federal.
} 
Com essa alteração, o elemento subjetivo - que até então vinha sendo considerado pela legislação como sendo a má-fé do terceiro, decorrente da existência de razão para este saber da pendência da ação e da situação patrimonial do devedor, - foi completamente excluído dessa hipótese de fraude de execução.

E, como essa era a única hipótese em que, tradicionalmente, o elemento subjetivo era relevante para a configuração da fraude de execução, verifica-se que o artigo 895 do código de 1939 aboliu completamente a exigência do elemento subjetivo como requisito legal para a configuração da fraude de execução. ${ }^{203}$

Não há registro, seja na exposição de motivos do projeto de lei que deu origem ao Código de Processo Civil de 1939, apresentada por FRANCISCO CAMPOS, ${ }^{204}$ seja nos comentários e observações doutrinárias feitos posteriormente à promulgação de seu texto definitivo, de qual teria sido a razão que levou o legislador a suprimir a necessidade de se demonstrar a possibilidade de ciência do terceiro como requisito para a configuração dessa hipótese de fraude de execução.

Sabe-se, contudo, que na elaboração do código de 1939 havia a intenção de alterar drasticamente a disciplina da fraude de execução, procurando mecanismos mais eficazes para sua repressão, ainda que com o aumento do risco para terceiros de boa-fé. É o que se extrai da conferência sobre o anteprojeto do código, realizada em 17 de maio de 1939, em que seu autor, PEDRo BATISTA MARTins, afirmava ser preciso "que a fraude não encontre no pretório, como sóe acontecer, o clima propício à sua expansão e crescimento, e, para a realização da obra saneadora, é necessário que se crie a possibilidade de riscos

\footnotetext{
${ }^{203}$ Nesse sentido, Hahnemann Guimarães, ao comparar a disciplina da fraude de execução do artigo 895 do Código de Processo Civil de 1939 com a do artigo $494^{\circ}$ do Regulamento 737, diz que uma das principais diferenças é inexigência da scientia fraudis antes definida no parágrafo $3^{\circ}$ do artigo $494^{\circ}$ (cf. GUIMARÃES, Hahnemann. Fraude de execução, cit., p. 124). Foi também à luz desse dispositivo que escreveram Pontes de Miranda: "tôda indagação da má-fé é estranha à concepção do instituto, em qualquer dos incisos do art. 895. (...) É preciso que não se intrometa no assunto da fraude à execução o elemento da culpa, nem, tão-pouco, do lado do adquirente, o elemento da má-fé. (...) O suporte fático da fraude à execução nada tem a ver com o suporte fático da fraude contra credores." (MIRANDA, Francisco Cavalcanti Pontes de. Comentários ao Código de Processo Civil. 2. ed. Rio de Janeiro: Forense, 1961. t. 13, p. 139-140) e Liebman: "a lei dispensa a prova do elemento subjetivo da fraude, do consilium fraudis. A intenção fraudulenta está in re ipsa." (LIEBMAN, Enrico Tullio. Processo de execução, cit., p. 108).

${ }^{204}$ Cf. MARTINS, Pedro Batista; LEAL, Victor Nunes. Código de Processo Civil com índice alfabético e analítico precedido da Exposição de Motivos do Ministro Francisco Campos. Rio de Janeiro: José Olympio, 1939. p. VII a XXV.
} 
para os terceiros que a protegem com sua cumplicidade ou a estimulam com a sua displicência."205

De fato, verificando o projeto de lei que deu origem ao código de 1939, observa-se que, no dispositivo que tratava da fraude de execução (art. 1.118), ${ }^{206}$ estavam previstas outras duas hipóteses que não constaram da redação definitiva. A primeira tratava da alienação feita após o protesto do título extrajudicial que ensejasse ação executiva, já existente nos códigos do Distrito Federal e de São Paulo. A segunda - inédita na legislação anterior - tratava da alienação após haver "mandado de inibição" contra o alienante. ${ }^{207}$

Sabe-se, também, que o Código de Processo Civil de 1939 previa, no caput de seu artigo 50, a obrigatoriedade do registro das ações em curso nos cartórios distribuidores, para facilitar as buscas por eventuais interessados, ${ }^{208}$ inspirando-se, nesse ponto, no já analisado artigo 118 do código processual do Estado de São Paulo. ${ }^{209}$

Os fatos antes narrados autorizam sustentar que a supressão da menção à possibilidade de conhecimento do terceiro na norma do inciso II do artigo 895 do código

${ }^{205}$ MARTINS, Pedro Batista. Em defesa do ante-projeto de Código de Processo Civil, cit., p. 417.

${ }^{206}$ Assim dispunha do texto do artigo projetado que veio a dar origem ao artigo 895 do texto definitivo:

"Art. 1.118. Considerar-se-ão alienados os bens em fraude de execução:

I- quando sobre eles for movida ação real ou reipersecutória;

II- quando a alienação for feita depois de protestado o título exequendo, nos casos de ação executiva;

III- quando houver mandado de inibição contra o alienante;

IV- quando, na época da alienação, já pendia contra o alienante qualquer demanda capaz de alterar o estado do seu patrimônio reduzindo-o à insolvência.

V- nos casos de falência, quando alienados no período de suspeição." (VIEIRA, Cícero Augusto (Org.). Projeto do Código de Processo Civil e Comercial dos Estados Unidos do Brasil. São Paulo: Brasileira, 1939. p. 212).

É interessante notar que nem esse projeto, nem o anteprojeto elaborado em 1935 continham a cláusula

genérica existente no inciso IV do artigo 895 do texto definitivo.
${ }^{207} \mathrm{~A}$ "inibição", mencionada nessa segunda hipótese, era uma medida preventiva constante dos artigos 888 a 893 do projeto, e que também não passou para o texto final do código de 1939. Tal medida poderia ser requerida pelo credor quando já lhe coubesse mandado de penhora e se verificasse a insuficiência de bens do devedor passíveis de serem penhorados. Pelo que se pode depreender do projeto, a consequência da decretação da inibição seria a sua publicação, por três vezes, no órgão oficial do Estado e no jornal local de maior circulação, e registro em livro próprio, para ciência de terceiros, presumindo-se em fraude de execução a alienação praticada pelo devedor a partir de então. (cf. VIEIRA, Cícero Augusto (Org.). Projeto do Código de Processo Civil e Comercial dos Estados Unidos do Brasil, cit., p. 168-169).

208"Art. 50. Os feitos serão obrigatoriamente distribuidos e registados." Em comentário a esse artigo, Herotides da Silva Lima dizia que, naquela época, a distribuição já não se destinava apenas a dividir o trabalho entre os juízes "mas a servir também de registro estatístico das causas, proporcionando aos interessados meios de procura das suas questões e negócios, um centro de indagação de litígios respeitantes às pessoas e bens" e, mais adiante, ressaltando a obrigatoriedade do registro, completava: "os processos dependentes de outros já distribuídos não necessitam de distribuição, mas devem passar pelo cartório distribuidor para o competente registro na forma do art. 50." (LIMA, Herotides da Silva. Código de Processo Civil brasileiro comentado. São Paulo: Saraiva, 1940. v. 1, p. 102 e 105). 
de 1939 tenha se baseado no seguinte raciocínio: dada a obrigatoriedade do registro de ações em curso e a possibilidade de sua consulta pelo público em geral, a simples pendência da demanda já corresponderia à existência de razão para que o terceiro soubesse desse fato, dispensando sua prova pelo credor. ${ }^{210}$

De toda forma, independentemente de o legislador ter se baseado nesse ou em qualquer outro raciocínio, o fato é que o requisito da existência de razão para que o terceiro soubesse da ação pendente foi efetivamente suprimido do texto legal - o que, na já citada lição de BARBOSA MOREIRA, corresponde à presunção absoluta desse elemento devendo essa alteração ser levada em consideração na análise da evolução do instituto. ${ }^{211}$

${ }^{209}$ O código de 1939 não previa, contudo, a criação de um registro geral centralizado como o previsto no artigo $1.119, \S 2^{\circ}$, do código paulista, até porque, devido à extensão geográfica do país, às diferenças na organização das diversas justiças e às limitações tecnológicas da época, isso seria praticamente impossível.

${ }^{210}$ Além do trecho da conferência e dos artigos já citados, essa interpretação encontra lastro em julgados da época sobre a aplicação do artigo 895, II:

"Fraude de execução - alienação, pelo devedor, do único imóvel de sua propriedade, na pendência de demanda capaz de alterar-lhe o patrimônio, reduzindo-o à insolvência - Simples ajuizamento da causa considerado como tal - Inteligência do art. 895, n. II, do Código de Processo Civil. (...) No caso em apreço, é de se atentar na situação do comprador referido na certidão de fls. Admitindo-se a inocência de sua parte, à primeira vista parece injusto seja êle a final o único sacrificado. Mas, nos tempos que correm, pagará êle apenas o prêço de sua incúria, pois a êle lhe competia, no domicílio do vendedor, indagar de sua situação, a partir dos cartórios." (TJGO, Agravo de Petição, rel. Des. Maximiano da Mata Teixeira, j. 29.07.48, in RT 185/426).

"Caracteriza-se a fraude de execução se ao tempo da alienação já pendia contra o alienante demanda capaz de alterar-lhe o patrimônio, reduzindo-o à insolvência. Nos têrmos do art. 895, II, do Código de Processo não há cuidar da boa-fé do adquirente. (...) O texto é claro. Quem compra corre os riscos da imprudência de não verificar se o vendedor tem contra si demanda pendente, nas condições previstas pelo legislador." (TJSP, $6^{\mathbf{a}}$ Câm. Civ., Apel. 56.784, rel. Des. Edgard de Moura Bittencourt, j. 19.11.51, in RT 198/271).

"Não exige o Código, para que se configure a fraude de execução, a inscrição da penhora. (...) Tivesse o embargante o cuidado de procurar no distribuidor do Fôro da Capital, e logo encontraria que contra o alienante corria uma ação executiva na qual dito caminhão já se achava até penhorado." (TAC-SP, $2^{\text {a }}$ Câm., A.I. 1.738, rel. Juiz Alcides Faro, j. 14.05.52, in RT 203/524).

"No caso, de há muito, recaía penhora sôbre a coisa negociada. Houvessem os adquirentes tomado a simples cautela de solicitar certidão ao distribuidor da comarca - medida comezinha de prudência, usual em todos os negócios imobiliários - e desde logo teriam recusado a oferta que o devedor lhes fazia. Diz o art. 895 do Código de Processo Civil que 'a alienação de bens considerar-se-á em fraude de execução: I- ... II- quanto, ao tempo da alienação já pendia contra o alienante demanda capaz de alterar-lhe o patrimônio, reduzindo-o à insolvência.' Precisamente o caso dos autos. O proprietário era devedor ao embargado. Êste fêz penhorarlhe o único imóvel que possuía. $\mathrm{O}$ executado procurou fugir à sua obrigação, alienando a coisa penhorada. Conseguiu que os embargantes, desatentos, à existência da demanda posta em juízo, a adquirissem. Teria, se quisesse, abusado da boa-fé dêstes. Não importa. A alienação resultou em fraude da execução, isto é, em prejuízo da execução." (TJSP, 6 ${ }^{a}$ Câm. Civ., A.I. 91.281, rel. Des. Laurindo Minhoto Júnior, j. 22.03.59, in $R T$ 288/424).

${ }^{211}$ Sobre esse ponto, mais uma vez oportuna a lição do autor sobre a presunção absoluta: "no caso da presunção absoluta, e talvez mesmo em algumas hipóteses de presunção relativa, esta segunda linha de raciocínio, baseada na dificuldade da prova, assume tamanho relevo que chega a impor-se por si mesma, relegada a plano secundário (quando não desprezada de todo) aquela que se relaciona com o juízo de probabilidade: em geral as duas idéias andam de braços dados, mas não fica excluído que se estabeleça presunção legal principalmente (ou até exclusivamente) por temer-se que a extrema dificuldade de provar o fato presumido conduzisse, na prática, a uma injustiça. Todas essas considerações, entretanto - e aqui se toca o punctum pruriens -, só têm relevância quando se pesquisa a ratio legis. São considerações que dizem respeito a uma opção do legislador e, portanto, se inscrevem no plano da política legislativa. Sua 
Ocorre que, diante da possibilidade de graves prejuízos a terceiros de boa-fé e ciente de que presunção absoluta da possibilidade de ciência de terceiro não correspondia à realidade dos fatos em todas as situações, a jurisprudência, inclusive do Supremo Tribunal Federal, frequentemente adotava interpretação contrária ao texto do artigo 895, II, e, valendo-se da aplicação analógica do artigo 107 do Código Civil de 1916, que se refere aos atos de alienação onerosos em fraude contra credores, exigia a presença do elemento subjetivo - também com a feição de má-fé do terceiro decorrente da ciência ou da existência de motivo para que esse soubesse da insolvência do devedor - para configurar a fraude de execução. ${ }^{212}$

relevância é, por assim dizer, pré-jurídica. Uma vez editada a norma, a respectiva eficácia manifesta-se com autonomia em relação aos motivos de conveniência ou de oportunidade que porventura a tenham inspirado; nem fica obscurecida essa verdade pelo papel que eventualmente possa desempenhar a ratio legis em matéria de interpretação." (BARBOSA MOREIRA, José Carlos. Presunções e prova, cit., p. 62 destaques no original).

${ }^{212}$ É o que se extrai dos seguintes julgados da época, inclusive do Supremo Tribunal Federal:

"O Dr. juiz de direito, para repelir êsses embargos, baseou-se no preceito do art. 895, n. ${ }^{\circ}$ II, do Cód. de Proc. Civil. (...) Quer dizer, considerou em fraude de execução e, portanto, nula de pleno direito, a venda da casa do executado aos terceiros embargantes, porque, quando feita, já estava proferida em primeira instância a sentença exequenda. Mas ao inciso legal citado, sob pena de desfechar em graves absurdos, não se pode atribuir a significação estritamente literal que lhe deu a sentença: êle há de ser entendido, não pelo sêco teor com que soam suas palavras, senão de harmonia com os princípios de direito que informam e impregnam a nossa legislação civil e processual, de que na fraude de execução, não basta que haja uma demanda pendente para que se possa anular tôda alienação de bens feita pelo réu, mas que da mesma forma por que acontece na fraude de credores, regulada no art. 107 do Cód. Civil, necessário será, para se invalidar a alienação, que a insolvência do alienante seja notória ou haja motivo para ser conhecida do outro contraente. (...) Cumpria ao recorrido demonstrar - e êle não o fêz - não só que os recorrentes tinham, ou deviam ter, conhecimento da existência dessa demanda, como também que sabiam, ou deviam saber, que tal demanda era capaz de reduzir o devedor à insolvência." (TJSP, $1^{a}$ Câm. Civ., Apel. 29.829, rel. Des. J. M. Gonzaga, j. 27.01.47, in Revista Forense 122/171, março de 1949).

"Não basta que haja pendente contra o alienante uma demanda para que se caracterize a fraude de execução e se possa anular a venda dos bens do devedor. Indispensável se torna a prova de que houve entre alienante e adquirente, um conluio fraudulento." (TJSP, $3^{\mathrm{a}}$ Câm. Civ., Apel. 48.665, rel. Des. Juarez Bezerra, j. 24.08.50, com voto vencido do Des. Prado Fraga, que sustentava a desnecessidade da ciência do comprador com apoio na doutrina de Liebman, in $R T$ 190/203).

"Não há fraude de execução sem o concurso de três elementos: demanda pendente, inexistência de outros bens do devedor e ciência da fraude por parte do adquirente." (TAC-SP, $2^{\mathrm{a}}$ Câm., Apel. 20.092, rel. Juiz João Pinto Cavalcante, j. 25.09.57, in PAULA, Alexandre de. O processo civil à luz da jurisprudência. Rio de Janeiro: Forense, 1960. v. 27, p. 2.473).

"A hipótese deve ser estudada à luz dos princípios que regem a ação pauliana, sem que isso importe em ofensa ao texto do art. 895, II, do Cód. de Proc. Civil, em sua literalidade. O entendimento jurisprudencial segue êsses rumos, abrindo margem à melhor distribuição de justiça através do exame que deve comportar cada caso dentro da esfera autônoma dos juízes e tribunais locais. Na fraude de execução certo é que não basta haja uma demanda pendente para que se possa anular tôda alienação de bens feita pelo réu, impondose que, da mesma forma como acontece na fraude de credores, prevista no art. 107 do Cód. Civil, se observa como essencial para se invalidar a alienação que a insolvência do alienante seja notória ou motivo haja para ser conhecida do outro contratante. (...) Assim, é irrecusável a necessidade da prova de que o adquirente sabia ou devia saber da pendência da demanda de que trata o art. 895, II, da Lei Processual." (STF, $2^{\mathrm{a}}$ T., rel. Min. Álvaro Moutinho Ribeiro da Costa, RE 36.449, j. 08.11.57).

"A existência de demanda não basta para caracterizar a fraude de execução, nos têrmos do art. 895, II, do Código de Processo Civil. É necessário que a demanda seja capaz de reduzir o contratante à insolvência e que essa circunstância seja conhecida do outro contratante ou notória." (TJPR, 2 ${ }^{\text {a }}$ Câm., A.I. 45-59, rel. 
AMÍlCAR DE CASTRO também fazia interpretação que acabava por reintroduzir o elemento subjetivo na hipótese do inciso II do artigo 895. Valendo-se de interpretação conjunta com o artigo 280 do Decreto n. ${ }^{\circ} 4.857 / 1939$ - que, como visto acima, dispunha sobre o registro da penhora -, extraía a seguinte conclusão: “o fato, porém, de não ter sido registrada, ou inscrita, a penhora (...) não impede a alegação de fraude contra a execução, e, sim, somente tem a significação de ficar o exequente com o onus de provar que o adquirente tinha conhecimento (...) de que pendia contra o alienante demanda capaz de lhe alterar o patrimônio de tal sorte que ficaria reduzido à insolvência." $" 213$

No entanto, vista à luz da evolução histórica do instituto, fica claro que, nessa interpretação, o autor misturava normas relativas a duas hipóteses distintas de fraude de execução, em que a relevância do elemento subjetivo era tratada de forma absolutamente distinta, quais sejam, a alienação de bem penhorado (cf. $\S 2^{\circ}$ do art. $494^{\circ}$ do Reg. 737), para a qual a má-fé do terceiro era irrelevante, e a alienação na pendência de ação que pudesse reduzir o devedor à insolvência (cf. § $2^{\circ}$ do art. 494º do Reg. 737), em que se exigia a demonstração da má-fé do terceiro, decorrente da existência de razão para esse saber da pendência da ação e da situação patrimonial do devedor.

Assim, a inscrição da penhora que, pelas sugestões de PHILADELPHO AZEVEDO, ligava-se a hipótese de presunção absoluta, constituindo condição para a configuração da fraude de execução decorrente da alienação de bem penhorado (cf. arts. 969, III, e 950, I, dos códigos do Distrito Federal e de São Paulo, respectivamente), passou a ser vista por AMÍLCAR DE CASTRO como causa ensejadora de presunção relativa, servindo apenas para alterar a distribuição do ônus de prova do elemento subjetivo.

Des. Jairo Campos, j. 30.06.59, in PAULA, Alexandre de. O processo civil à luz da jurisprudência, cit., p. 2.484).

${ }^{213}$ CASTRO, Amílcar de. Comentários ao Código de Processo Civil, cit., v. 10, p. 77. Essa interpretação, contudo, mostrava-se contraditória com outra passagem da mesma obra em que o autor, analisando a possibilidade de inscrever a hipoteca judiciária prevista no artigo 274 do mesmo Decreto n. ${ }^{\circ}$ 4.857/1939, considerava a inscrição no registro imobiliário importante apenas para o caso da alienações posteriores a terceiros mediatos. Confira-se: "atualmente, os bens do executado se consideram alienados em fraude de execução quando ao tempo da alienação já pendia contra o alienante demanda capaz de alterar-lhe o patrimônio, reduzindo-o à insolvência; e neste caso, note-se bem, independentemente de inscrição (art. 267 do Reg. 18.542, e art. 281 do decreto n. ${ }^{\circ}$ 4.857), consideram-se os bens alienados em fraude de execução, e (atenção) para prevenir posteriores alienações, a terceiros sub-adquirentes a título oneroso, que se acham a abrigo da revocatória, pode o credor vincular à inscrição de uma hipoteca judiciária os bens já alienados em fraude de execução." (CASTRO, Amílcar de. Comentários ao Código de Processo Civil, cit., v. 10, p. 84-85 - destaques e parênteses no original). 
Não obstante tal incongruência, parte da jurisprudência também passou a adotar essa interpretação para abrandar o rigor da norma do artigo 895, II. ${ }^{214}$

Repetia-se, portanto, o fenômeno já verificado em relação aos $\S \S 1^{\circ}$ e $2^{\circ}$ do artigo 494 do Regulamento 737: constatando que a presunção absoluta instituída pelo legislador contrariava a realidade dos fatos, ${ }^{215}$ gerando injustiças aos terceiros de boa-fé, a jurisprudência julgava contra legem, reinserindo o elemento subjetivo como requisito para a configuração da fraude de execução.

Nota-se que a situação verificada com o artigo 895 do código de 1939 era, de certa forma, mais grave do que a ocorrida durante a vigência dos $\S \S 1^{\circ}$ e $2^{\circ}$ do artigo $494^{\circ}$ do Regulamento 737 . Neste último caso, o artigo $494^{\circ}$ previa a necessidade do elemento subjetivo para a hipótese de seu $\S 3^{\circ}$ e a jurisprudência procurava generalizar ou ampliar a exigência desse requisito para as três situações previstas em seus $\S \S$.

Já no caso do código de 1939, o elemento subjetivo havia sido excluído completamente do tipo legal e o que fez a jurisprudência foi reinseri-lo valendo-se de interpretação conjunta do artigo 895 com o artigo 107 do Código Civil ou com os artigos 280 e 281 do Decreto n. ${ }^{\circ} 4.857 / 1939$.

Essa completa ausência do elemento subjetivo do tipo legal contribuiu, ainda, para que sua feição original se perdesse. Assim, enquanto no regime anterior a lei esclarecia que má-fé do terceiro decorria da mera existência de razão para que esse soubesse da ação pendente e do estado patrimonial do devedor, na vigência do código de 1939, a interpretação variava e, seguindo a sustentada por AMÍLCAR DE CASTRO com base na legislação de registros públicos, passou-se a exigir a ciência desses fatos pelo terceiro para a configuração de sua má-fé.

Finalizando a análise desse terceiro período, verifica-se que, no que diz respeito à disciplina da fraude de execução, a legislação registrária não apresentou alterações, tendo o Decreto n. ${ }^{\circ} 4.857 / 1939$ se limitado a repetir os três dispositivos do

\footnotetext{
214"O fato de não ter sido inscrita a penhora não impede a alegação de fraude contra a execução; mas, nesse caso, fica ao exequente o ônus da prova de que o adquirente tinha conhecimento da existência de ação contra o alienante capaz de reduzi-lo à insolvência." (TJSP, $1^{\text {a }}$ Câm., A.I. 87.127, rel. Des J. Cavalcanti Silva, j. 11.04.58, in RT 277/453).

215"Presumia contra a verdade dos fatos", dizia Philadelpho Azevedo a respeito da norma do Regulamento 737 (cf. AZEVEDO, José Philadelpho de Barros e. Da fraude contra sentenças, cit., p. 21).
} 
Decreto n. ${ }^{\circ}$ 18.542/1928 referentes à possibilidade de inscrição, no registro imobiliário, da hipoteca judiciária, da penhora e das citações em ações reais e reipersecutórias.

$\mathrm{Na}$ legislação processual, contudo, houve profunda alteração, pois o código de 1939: (i) eliminou a hipótese de fraude de execução decorrente de alienação de bem penhorado, originalmente prevista no $\S 2^{\circ}$, do artigo $494^{\circ}$ do Regulamento 737 ; (ii) eliminou a exigência do elemento subjetivo para a configuração da hipótese de fraude de execução referente à pendência de ação que possa reduzir o devedor à insolvência; (iii) inseriu hipótese referente à alienação após a decretação da falência; e (iv) inseriu norma remissiva genérica, sem definição quanto ao seu conteúdo.

Tais alterações promovidas na legislação processual romperam o paralelismo com a legislação registrária alcançado no período anterior, gerando grandes dificuldades de interpretação e reavivando a tendência jurisprudencial de desconsiderar a letra da lei quando esta instituía presunção absoluta de fraude contra a realidade dos fatos.

Assim, em relação à relevância do elemento subjetivo para a hipótese de fraude de execução decorrente da pendência de ação real ou reipersecutória, verificou-se que (i) o artigo 281 do Decreto n. ${ }^{\circ}$ 4.857/1939 - tal qual a legislação registrária anterior previa que a litigiosidade do bem dependia da inscrição da citação do réu nessas ações no registro imobiliário; e (ii) o inciso I do artigo 895 do código de 1939 - diferente, por exemplo, do código processual paulista - não estabelecia tal inscrição como requisito para a fraude de execução. Desse descompasso legislativo, surgiu a seguinte interpretação: não estando inscrita a citação no registro imobiliário, para a configuração da fraude de execução, o credor deveria provar, por outros meios, que o terceiro tinha ciência da ação.

Em outras palavras, diferentemente da disciplina anterior, inexistindo a inscrição no registro de imóveis, passou-se a exigir a má-fé do terceiro, decorrente de sua ciência quanto à pendência da ação real ou reipersecutória.

Já no tocante à hipótese de fraude de execução prevista no artigo 895, II, embora também nada fosse previsto em relação à necessidade de presença do elemento subjetivo, em razão da existência de riscos a terceiros de boa-fé, a jurisprudência passou a exigi-lo, valendo-se de aplicação conjunta com o artigo 107 do Código Civil de 1916 ou com o artigo 280 do Decreto n. ${ }^{\circ} 4.857 / 1939$, nesse último caso, com base na doutrina de AMÍlCAR DE CASTRO. Com isso, a feição do elemento subjetivo começou a se alterar, uma 
vez que, para esse autor, a má-fé do terceiro decorreria de sua ciência da pendência da ação e da condição do patrimônio do devedor e não apenas da existência de motivo para que esse soubesse desses fatos, como no regime anterior.

\section{4- Quarto período (1973-2009): o Código de Processo Civil de 1973, a manutenção das alterações de 1939 e a inserção, pelas reformas processuais de 1994, 2002 e 2006, de normas incompativeis com o sistema adotado originalmente pelo código}

O Código de Processo Civil vigente, tal como foi promulgado em 11 de janeiro de 1973, não trouxe alterações relevantes na disciplina da fraude de execução, prevendo-a em seus artigos 592, V, e 593, que praticamente repetiam os artigos 888, V, e 895, do código de 1939:

\footnotetext{
“Art. 592. Ficam sujeitos à execução os bens: (...)

V - alienados ou gravados com ônus real em fraude de execução.

Art. 593. Considera-se em fraude de execução a alienação ou oneração de bens:

I- quando sobre eles pender ação fundada em direito real;

II- quando, ao tempo da alienação ou oneração, corria contra o devedor demanda capaz de reduzi-lo à insolvência;

III- nos demais casos expressos em lei."
}

Além das observações já feitas no item 2.3, supra, sobre as hipóteses de fraude de execução na legislação atual - inteiramente aplicáveis aqui, tendo em vista que os artigos 592 e 593 não sofreram alterações desde a promulgação do Código de Processo Civil -, deve-se destacar que, o legislador de 1973 apenas substituiu a menção à espécie hipoteca - presente no artigo 888, V, do código de 1939, pelo gênero - ônus real - no artigo 592, V, do Código de Processo Civil, abrangendo assim também os outros direitos reais de garantia (penhor e anticrese) e os direitos reais de fruição. Além disso, foi eliminada do código atual a menção à hipótese de alienação de bens após a decretação da falência, prevista no inciso III do artigo 895 do código anterior. ${ }^{216}$

\footnotetext{
${ }^{216}$ Essa hipótese, contudo, continuou sendo disciplinada pela legislação especial. Inicialmente, pelo artigo 52, VII, do Decreto-Lei n. ${ }^{\circ} 7.661$, de 21 de junho de 1945. Quanto ao elemento subjetivo, o caput do referido artigo é expresso ao afirmar que a alienação será ineficaz "tenha ou não o contratante conhecimento do estado econômico do devedor, seja ou não intenção deste fraudar credores." Sobre o tema, reforça ainda
} 
Na hipótese prevista no inciso I do artigo 593 do CPC, o legislador substituiu a expressão "ação real" do artigo 895 do código de 1939 por "ação fundada em direito real" no código de 1973, eliminando, ainda, a menção à "ação reipersecutória".

Segundo AlCides MENDONÇA LiMA, com essa alteração, o legislador teria aprimorado a redação do código revogado, pois a expressão "ação real" anteriormente utilizada era tecnicamente condenável, uma vez que "a ação não é pessoal e nem real, mas sim o direito alegado por via da pretensão deduzida." Além disso, a menção à "ação reipersecutória", de conceito controvertido, gerava muitas dificuldades para a interpretação da norma. Para o autor, portanto, a expressão "ação fundada em direito real", utilizada no código de 1973, compreenderia ações em que "é pretendido bem certo, como v.g., na reivindicatória, ou a obrigação se acha vinculada a bem igualmente certo, se sujeito a ônus real (penhor, anticrese ou hipoteca).,"217

Quanto à segunda alteração há, contudo, que se ter cuidado. Não há dúvida de que a "ação reipersecutória" possuía conceito controvertido. ${ }^{218}$ No entanto, tal expressão servia para designar classe diversa da ação (fundada em direito) real. Tratava-se, a todo sentir, daquelas ações que, mesmo fundadas em direito pessoal, tinham por objeto um bem determinado - ou, no dizer de LIEBMAN, daquelas em que esse bem era "o objeto final da execução",219 - como as que se fundam em obrigação de entregar coisa certa. ${ }^{220}$

A exclusão da menção às "ações reipersecutórias" da hipótese do inciso I do artigo 593 poderia, portanto, dar ensejo à interpretação de que os bens alienados durante

\footnotetext{
Yussef Said Cahali que "tem-se como irrelevante a boa-fé daquele que com ele [devedor] contratou; a ineficácia estabelecida pelo art. 52 resulta exclusivamente da incidência do ato na hipótese prevista em lei, dispensada a fraude que, por uma fictio juris, é presumida, presunção juris et de jure". (CAHALI, Yussef Said. Fraudes contra credores, cit., p. 802). Atualmente, a matéria encontra-se no artigo 129 da Lei n. ${ }^{\circ}$ $11.101 / 2005$, já analisada.

${ }^{217}$ LIMA, Alcides de Mendonça. Comentários ao Código de Processo Civil, v. 6, t. 2, p. 566.

${ }^{218}$ Sobre a menção a ela feita no inciso I do artigo 895 do código de 1939, afirmavam Pontes de Miranda: "advertimos, há mais de quarenta anos (em nota à Doutrina das Ações de Correia Telles, 39), no perigo de se usar o conceito "ação reipersecutória" e mostramos que três dos nossos processualistas (Correia Telles, Teixeira de Freitas e Paula Batista) empregavam três diferentes conceitos. Nem o direito romano se firmara num só." (MIRANDA, Francisco Cavalcanti Pontes de. Comentários ao Código de Processo Civil, cit., t. 13, p. 371) e Amílcar de Castro: "encontra-se na doutrina certa divergência a respeito do que se deva entender por "ação reipersecutória". (...) Falando claro, está-se pisando areia movediça, e muito ainda se há de discutir sobre o que seja ação reipersecutória" (CASTRO, Amílcar de. Comentários ao Código de Processo Civil. Rio de Janeiro: Forense, 1941. v. 10, p. 74-75).

${ }^{219}$ LIEBMAN, Enrico Tullio. Processo de execução, cit., p. 109.

${ }^{220}$ Era também esse o conceito que se extraía do texto do Título 86 do Livro III das Ordenações Filipinas, que, conforme visto, serviu de base para a criação do instituto no Regulamento 737, referindo o $§ 15$ daquele título a "aução real, ou pessoal, que entregue cousa certa" (cf. ALMEIDA, Cândido Mendes de. Código Philipino ou Ordenações e Leis do Reino de Portugal, cit., Livro III, p. 702).
} 
o curso de ação condenatória ao cumprimento de obrigação de entregar coisa certa não poderiam ser mais alcançados no patrimônio de terceiro pelo sistema do código de 1973.

No entanto, tal interpretação não procede, pois, além dessa norma, o código atual contém outra, em seu artigo $42, \S 3^{\circ}$, na qual se estabelece claramente que o adquirente do bem litigioso é atingido pelos efeitos da sentença:

"Art. 42. A alienação da coisa ou do direito litigioso, a título particular, por ato entre vivos, não altera a legitimidade das partes. (...)

$\S 3^{\circ}$ - A sentença, proferida entre as partes originárias, estende seus efeitos ao adquirente ou ao cessionário."

Essa norma, inexistente no Código de Processo Civil de 1939, superpõese à do artigo 593, I, e possui maior abrangência que ela, ${ }^{221}$ uma vez que não distingue se o bem tornou-se litigioso em razão de ação fundada em direito real ou pessoal. ${ }^{222}$

Assim, atualmente, o bem que se encontre em poder de terceiro, em razão de alienação realizada no curso de ação que tenha por objeto precisamente a obrigação de entregá-lo, ainda pode ser alcançado pelas medidas executivas decorrentes

\footnotetext{
${ }^{221}$ Em sentido contrário, registre-se a posição de Carlos Alberto Alvaro de Oliveira, que defende uma separação absoluta entre as figuras previstas nesses dois dispositivos: "não há que confundir, pois, alienação de coisa ou direito litigioso com alienação em fraude à execução, esta só ocorre se o bem ou direito não são suscetíveis de ser alcançados pela força de alguma sentença, sendo no entanto atingíveis por algum ato de execução forçada. Assim, v.g., o réu sucumbente, transitada em julgado a sentença que, no processo de conhecimento, em ação reivindicatória, atribuiu a propriedade ao demandante, ao transferir apenas a obrigação de entregar o bem, na pendência do processo executivo, aliena direito litigioso no sentido do art. 42; se transfere o direito ao próprio bem, frauda a execução (art. 593, I)." (OLIVEIRA, Carlos Alberto Alvaro. Alienação da coisa litigiosa. 2. ed. Rio de Janeiro: Forense, 1986. p. 146-147).

Parece, contudo, que o autor, preocupando-se em bem caracterizar e delimitar o conceito do novo instituto, vindo, como se sabe, do direito alemão (ZPO, § 325), acabou por restringir demais seus limites, desconsiderando o sentido que historicamente o direito nacional dava ao conceito de coisa ou bem litigioso (cf. itens anteriores desse capítulo 4). Aplicável aqui, portanto, a lição de Pontes de Miranda: "o melhor método para se encontrar o exato conceito quando, na doutrina, há muitos da mesma palavra, é saber qual o conceito com que historicamente se formou a proposição. No direito anterior, as Ordenações Filipinas, Livro III, Título $86, \S 16$, falavam do que 'maliciosamente deixou de possuir a coisa julgada, por se não fazer em ela execução, depois da lide contestada em diante', e de 'dita coisa litigiosa'. No Livro IV, Título $10, \S 9$, referiam-se a 'emalhear-se' a 'coisa litigiosa'. 'Ação real' e 'ação reipersecutória' estavam no Código de 1939, art. 895, I, por ações em que a coisa fica 'litigiosa'." (MIRANDA, Francisco Cavalcanti Pontes de. Comentários ao Código de Processo Civil, cit., t. 9, p. 342). Ademais, se se adotasse a separação e o conceito esculpido pelo processualista gaúcho em sua brilhante tese, seria válida a interpretação de que, no sistema do código de 1973, os bens alienados durante o curso de ação condenatória ao cumprimento de obrigação de entregar coisa certa não poderiam sofrer atos de execução forçada no patrimônio de terceiro.

${ }^{222}$ Sobre a inexistência de distinção entre direitos pessoais ou reais para que a ação torne o bem litigioso, cf. TESHEINER, José Maria Rosa. Coisa litigiosa! Porto Alegre: CORAG, 1973. p. 7. Também a respeito, cf. SANTOS, Ernane Fidelis dos. Alienação da coisa litigiosa e intervenção de terceiros. Revista Dialética de
} 
dessa ação. Não por força da norma do artigo 593, I, do CPC, pois essa não estende mais tal hipótese de fraude de execução à ação reipersecutória, mas sim pelo $\S 3^{\circ}$ do artigo 42 do mesmo código, que abrange a alienação de bens litigiosos em ações fundadas tanto em direito real quanto em direito pessoal. ${ }^{223}$

Se, em relação às ações fundadas em direito real, a norma processual não se alterou nessa hipótese de fraude de execução, o mesmo não se pode dizer da legislação referente aos registros públicos.

De fato, a Lei n. ${ }^{\circ}$ 6.015, de 31 de dezembro de 1973 não continha disposição análoga ao já analisado artigo 281 do Decreto n. ${ }^{\circ}$ 4.857/1939 que, para efeitos de fraude de execução, condicionava a litigiosidade da coisa à inscrição, no registro imobiliário, da citação nas ações reais ou reipersecutórias. Havia desaparecido, portanto, da legislação registrária, a base normativa da exigência de registro para essa hipótese de fraude de execução. ${ }^{224}$

Direito Processual, São Paulo, n. 8, p. 25, nov. 2003 e DINAMARCO, Cândido Rangel. Instituições de direito processual civil. 6. ed. São Paulo: Malheiros, 2009. v. 2, p. 81.

${ }^{223}$ Percebendo lacuna semelhante no artigo 592, I, quanto à ausência de menção à "ação reipersecutória", o legislador, por meio da Lei n. ${ }^{\circ} 11.382$, de 6 de dezembro de 2006, houve por bem inserir, ao lado da execução "fundada em direito real" a referência também àquela que tem por base "obrigação reipersecutória".

Sobre essa alteração, esclarece Humberto Theodoro Júnior que "a reforma ampliou o alcance da norma" e que seu "campo de incidência é o das execuções para entrega de coisa (arts. 461-A c/c 475-I, e arts. 585, II, c/c 621 a 631). Não importa se o exequente esteja reclamando a entrega com fundamento em direito real ou pessoal." (THEODORO JÚNIOR, Humberto. A reforma da execução do título extrajudicial. Rio de Janeiro: Forense, 2007. p. 27).

${ }^{224}$ Inexistente na Lei n. ${ }^{\circ}$ 6.015/1973 a norma correspondente ao artigo 281 do Decreto n. ${ }^{\circ} 4.857 / 1939$; os defensores dessa interpretação passaram a apoiar-se na norma existente em seu artigo 169, que dispõe genericamente que "todos os atos enumerados no art. 167 são obrigatórios". Tal norma, contudo, não era nova, correspondendo ao artigo 179 do decreto de 1939, de modo que a supressão da norma anterior parece ser mais eloquente do que a manutenção dessa já existente para se analisar a evolução do instituto.

Outra norma existente no Decreto n. ${ }^{\circ} 4.857 / 1939$ que não foi repetida pela Lei n. $^{\circ}$ 6.015/1973 foi a prevista no artigo 274 daquele decreto, que dispunha sobre o regramento da hipoteca judiciária. Ao contrário do que acontecia com a legislação registrária e processual de 1939, no regime de 1973, a hipoteca judiciária passou a ser pontualmente mencionada na Lei de Registros Públicos (cf. art. 167, I, 2), enquanto o Código de Processo Civil (cf. art. 466) a regrava com maiores detalhes:

"Art. 167 - No Registro de Imóveis, além da matrícula, serão feitos:

I - o registro: (...)

2) das hipotecas legais, judiciais e convencionais;"

"Art. 466. A sentença que condenar o réu no pagamento de uma prestação, consistente em dinheiro ou em coisa, valerá como título constitutivo de hipoteca judiciária, cuja inscrição será ordenada pelo juiz na forma prescrita na Lei de Registros Públicos.

Parágrafo único. A sentença condenatória produz a hipoteca judiciária:

I - embora a condenação seja genérica;

II - pendente arresto de bens do devedor;

III - ainda quando o credor possa promover a execução provisória da sentença."

Se comparado com o art. 274 do Decreto n..$^{\circ}$ 4.857/1939, contudo, observa-se que o art. 466 não reproduziu a norma do $\S 2^{\circ}$ do artigo revogado, que previa que "o credor indicará, em petição, os imóveis sobre os quais 
Passando ao largo desse relevante fato, contudo, a interpretação de que, em se tratando de alienação de imóvel, a configuração da hipótese de fraude de execução do artigo 593, I, do CPC dependeria do registro da citação da ação real no cartório imobiliário ou da prova da ciência do adquirente foi se fortalecendo, sendo atualmente dominante tanto na doutrina ${ }^{225}$ quanto na jurisprudência. ${ }^{226}$

Com relação à hipótese do inciso II do artigo 593, o código de 1973 não trouxe alterações de relevo, praticamente mantendo o texto do inciso II do artigo 895 que fora criado pelo legislador de 1939. Apenas incluiu o termo "oneração" ao lado de "alienação", mantendo a correlação com o caput; substituiu os termos "pendia" por "corria" e "alienante" por "devedor"; e tornou mais direto o texto em relação ao efeito que deveria ter a demanda em curso: "alterar-lhe o patrimônio, reduzindo-o à insolvência" passou para "reduzi-lo à insolvência", sem modificação substancial de sentido.

deve recair a inscrição, com os requisitos necessários, ficando salvo ao devedor requerer ao juiz competente a redução ou substituição dos imóveis apontados."

${ }^{225}$ Sendo seus exemplos, a lição de Alcides de Mendonça Lima - já citada no início desta tese - de que "não basta, porém, a simples ação em juízo, já proposta, isto é, com a citação do réu (art. 263, $2^{\mathrm{a}}$ parte, deste Código), para que a 'fraude de execução' se caracterize de modo absoluto, envolvendo o terceiro adquirente. É indispensável a formalidade da inscrição da citação do réu em tais ações no Registro de Imóveis (...) Cabe ao exequente, sem a inscrição, o "ônus de provar que o adquirente tinha conhecimento de que sobre os bens está sendo movido litígio fundado em direito real." (Comentários ao Código de Processo Civil, v. 6, t. 2, p. 657-658) e também a de Moacyr Amaral Santos: "duas hipóteses há que se considerar: $1^{\mathrm{a}}$ ) se a citação, em dita ação, tiver sido levada à inscrição no Registro Geral de Imóveis, como determina a Lei n. ${ }^{\circ}$ 6.015, de 31 de dezembro de 1973, arts. 167, I, 21 e 169 (Lei dos Registros Públicos), a fraude independe de prova, porque se presume do fato do registro, pelo qual se tem o fato registrado como do conhecimento de todos e, portanto, do adquirente dos bens ou daquele em favor de quem foi feita a sua oneração; $2^{a}$ ) não tendo a citação sido levada àquele Registro, conquanto ainda aí exista a fraude, cumpre ao exequente prová-la, o que vale dizer que insta a este provar que o terceiro adquirente ou beneficiário com a oneração dos bens tinha conhecimento da ação pendente contra o alienante ou instituidor do ônus real." (SANTOS, Moacyr Amaral. Primeiras linhas de direito processual civil. 3. ed. São Paulo: Saraiva, 1979. v. 3, p. 235236).

Em sentido contrário, defendendo a irrelevância do registro ou da prova da ciência do terceiro, cf. o entendimento de Arruda Alvim: "exegese da Lei 6.015/1973, art. 167, n. 21, e art. 169 com o sistema do Código de Processo Civil. (...) A previsibilidade da inscrição da ação real, leva à necessidade de que se interprete essa norma e que se extraiam as consequências jurídicas da inscrição ou não, de uma ação real. (...) Em face dos arts. 42, caput, e 42, $\S 3^{\circ}$, e 626, citados, a sentença pode ser executada contra o terceiro, mesmo que este esteja de boa-fé, e mesmo que a demanda não tenha sido inscrita." (ALVIM, Arruda. O terceiro adquirente de bem imóvel do réu, pendente ação reivindicatória não inscrita no registro de imóveis, e a eficácia da sentença em relação a esse terceiro, no direito brasileiro. Revista de Processo, São Paulo, v. 8, n. 31, p. 195, jul./set. 1983).

226"A orientação dominante, na doutrina e na jurisprudência, inclusive do STF, é a de que a venda de bens sujeitos, eventualmente, aos efeitos da sentença a ser proferida em ação real ou reipersecutória, só é assumida, em caráter absoluto, como feita em fraude à execução, quando a citação para a demanda tiver sido inscrita no Registro de Imóveis." (STF, Pleno, EAR. 732-8-RJ, rel. Min. Soares Muñoz, j. 28.02.80, in RTJ 116/870). "Não havendo a inscrição, de que fala a Lei n. ${ }^{\circ} 6.015 / 73$, art. 167, n. ${ }^{\circ} 21$, incumbe ao credor o ônus de provar a fraude de execução." (STF, $1^{\text {a }}$ T., Ag. 96.838/SP, rel. Min. Alfredo Buzaid, j. 20.03.84, in RTJ 111/690). A jurisprudência, contudo, permanecia oscilando, havendo na mesma época decisões fiéis à presunção absoluta inserida no artigo 593, I, do código: "é irrelevante que a ação proposta esteja inscrita no Registro de Imóveis para caracterizar-se a fraude à execução pois que esta sempre se presume juris et de jure. (1º TAC-SP, $1^{\text {a }}$ Câm., Apel. 347.457, rel. Juiz Guimarães e Souza, j. 22.10.1985, in RT 607/120). 
Neste ponto, o descompasso entre a legislação registrária e processual permanecia, uma vez que a Lei n. ${ }^{\circ} 6.015 / 1973$ repetiu em seu artigo 240 o texto do artigo 280 do Decreto n. ${ }^{\circ} 4.857 / 1939$, que previa a possibilidade de inscrição da penhora no registro imobiliário, permanecendo sem correspondência com o artigo 593 do código de 1973 que, tal qual o artigo 895 do código de 1939, não previa a alienação de bem penhorado como hipótese de fraude de execução.

Quanto à relevância do elemento subjetivo para a configuração da hipótese de fraude de execução prevista nesse inciso II, a oscilação da jurisprudência, que já vinha se fazendo sentir durante a vigência do Código de Processo Civil de 1939 e do Decreto n. ${ }^{\circ} 4.857 / 1939$, agravou-se ainda mais, dando ensejo à formação dos diversos entendimentos expostos na introdução desta tese. Já nessa época era possível verificar, basicamente, três diferentes correntes.

A primeira delas, fundada na literalidade do artigo 593, II, do CPC considerava o elemento subjetivo irrelevante à configuração dessa hipótese de fraude de execução, bastando a aferição da presença de dois elementos objetivos, quais sejam, a pendência de processo e a insuficiência de bens sujeitos à penhora, causada ou agravada pelo ato de alienação ou oneração de que participou o terceiro. ${ }^{227}$

A segunda corrente sustentava que o registro da penhora - ou a necessidade de prova, pelo credor, da ciência do terceiro - só era necessário para a configuração da fraude de execução no tocante à alienação feita a terceiros mediatos. É interessante notar que tal corrente baseava-se no mesmo espírito que no passado inspirara a criação da norma do $\S 12$ do artigo $3^{\circ}$ da Lei n. ${ }^{\circ} 1.237 / 1864 .^{228}$ Nessa época, era a corrente

\footnotetext{
227، Considera-se em fraude à execução a alienação feita quando já corria contra o devedor demanda capaz de reduzi-lo à insolvência, bastando para tanto o simples ajuizamento da ação contra o devedor, ainda que este não tivesse sido citado. (...) Na fraude à execução, a boa-fé de terceiro adquirente sucessivo é irrelevante, bastando que o devedor tivesse ficado sem bens suficientes para garantir a execução." (TJSP, 7 Câm. Civ., Apel. 174.038-1, rel. Des. Benini Cabral, j. 23.09.92. No mesmo sentido: RTJ 79/621; RTs 494/204, 601/125 e 609/107 e JTA 91/126, 100/41 e 104/61; RF 256/296. REsp. 34.189/RS).

${ }^{228}$ Como visto no item 4.1, supra, a norma do $\S 12$ do artigo $3^{\circ}$ da Lei $n .{ }^{\circ} 1.237$ de 1864 , previa que o credor possuía o direito de prosseguir com a execução contra os adquirentes dos bens alienados pelo devedor, mas, para ser oposto contra terceiros mediatos, dependia de inscrição no registro imobiliário. Nessa época, essa norma permanecia vigente no artigo 824 do Código Civil de 1916. Curiosamente, porém, a distinção da necessidade da inscrição para terceiros imediatos ou mediatos para efeito de configuração da fraude de execução nunca mereceu maior interesse por intérpretes, ficando sua análise limitada à figura da hipoteca judiciária e às discussões sobre seus efeitos, calcada na separação absoluta que Lafayette fizera entre os institutos da hipoteca judiciária e da fraude de execução no $\S 208$ de seu célebre Direto das Cousas. De fato, tamanha foi a influência de Lafayette no direito nacional - como relata Sálvio de Figueiredo Teixeira (A presença admirável, no Império, do Conselheiro Lafayette Rodrigues Pereira. BDjur, Brasília, DF. Disponível em: <www.http://bdjur.stj.gov.br/dspace/handle/2011/8847>. Acesso em 24 nov. 2009) -, que
} 
que prevalecia, ao menos na $2^{\text {a }}$ Seção do Superior Tribunal de Justiça, como se observa dos Embargos de Divergência no Recurso Especial n. ${ }^{\circ}$ 114.415/MG, julgado em 12 de novembro de 1997 e em outros julgados. ${ }^{229}$

Finalmente, a terceira corrente - em sentido diametralmente oposto à primeira - exigia que o credor comprovasse que o terceiro adquirente - fosse ele imediato ou mediato - estava de má-fé, caso não houvesse registro da penhora. ${ }^{230}$

É interessante notar que, nesse período, a discussão sobre a relevância do elemento subjetivo nas hipóteses de fraude de execução não se dava mais em função da interpretação conjunta com o artigo 107 do Código Civil de 1916, como ocorrera durante a vigência do código de 1939, e sim com os artigos 167, 169 e 240 da Lei 6.015/1973, relativos ao registro da penhora. Também passou a prevalecer nos acórdãos a posição de que a má-fé do terceiro decorria de sua ciência da ação pendente que poderia reduzir o devedor à insolvência e não mais da mera existência de razão para tal ciência.

Tal alteração interpretativa pode encontrar explicação tanto no prestígio que angariou de AMÍLCAR DE CASTRO, seu precursor, ${ }^{231}$ como na prevalência da corrente que prega a total separação do instituto em relação à fraude contra credores. ${ }^{232}$

não é de admirar que a interpretação diversa, sustentada à época por Antonio Almeida Oliveira, entre outros, (como visto no item 4.1, supra) tenha sido fadada ao esquecimento.

${ }^{229}$ "Bem penhorado. Alienação feita por quem o adquirira do executado. Hipótese anterior à vigência da Lei 8.953/1994. Não registrada a penhora, a ineficácia da venda, em relação a execução, depende de se demonstrar que o adquirente, que não houve o bem diretamente do executado, tinha ciência da constrição. Prevalência da boa-fé." (STJ, 2 ${ }^{a}$ Seção, EREsp. 114.415/MG, rel. Min. Eduardo Ribeiro, j. 12.11.97). No mesmo sentido, "ainda que admitida como não eficaz a alienação de bem penhorado, mesmo se omitido o registro da penhora, ainda assim tal ineficácia não poderia ser oposta ao terceiro que haja adquirido o imóvel de quem o comprou do executado. Necessidade de tutela à boa-fé, que em tal caso presume-se com maior evidência" (STJ, 4ª T., REsp. 9.789/SP, rel. Min. Athos Carneiro, j. 09.07.92); "não registrada a penhora, a ineficácia da venda, em relação à execução, depende de se demonstrar que o adquirente, que não houve o bem diretamente do executado, tinha ciência da constrição." (STJ, 4 ${ }^{\mathrm{a}}$ T., REsp. 185.138/SP, rel. Min. Sálvio de Figueiredo Teixeira, DJ. 28.06.99).

${ }^{230}$ "Para que se tenha como de fraude de execução a alienação de bens, de que trata o inciso II do art. 593, do Código de Processo Civil, é necessária a presença concomitante dos seguintes requisitos: a) que a ação já tenha sido aforada; b) que o adquirente saiba da existência da ação - ou por já constar no cartório imobiliário dando conta de sua existência (presunção juris et de jure contra o adquirente) - ou porque o exequente, por outros meios, provou que do aforamento da ação o adquirente tinha ciência..." (STJ, $4^{\mathrm{a}}$ T., REsp. 40.854/SP, rel. Min. Cesar Asfor Rocha, j. 12.08.97).

${ }^{231}$ Como se observa, a lição de Amílcar de Castro é frequentemente citada nesses acórdãos.

${ }^{232} \mathrm{Cf}$., por exemplo, Pontes de Miranda: "a fraude de execução é instituto de direito processual, que se não confunde, posto que em muitos pontos coincida com a fraude contra credores, que pertence ao direito material." (MIRANDA, Francisco Cavalcanti Pontes de. Comentários ao Código de Processo Civil, cit., t. 9, p. 340), já defendendo essa ideia na vigência do código de 1939 (cf. MIRANDA, Francisco Cavalcanti Pontes de. Comentários ao Código de Processo Civil, cit., t. 13, p. 98). Tal corrente acabou superando, portanto, a que sustentava a complementaridade das normas sobre fraude de execução, prevista na legislação processual, com aquelas sobre fraude contra credores, previstas no Código Civil, defendida, por 
Ainda em relação às diferenças entre os sistemas dos códigos de 1939 e 1973, cabe analisar outra alteração não diretamente ligada à disciplina da fraude de execução, mas que exercia inegável influência sobre ela. Trata-se da modificação do momento em que o legislador considerava "proposta a ação".

Enquanto o sistema do código de 1939 considerava proposta a ação e iniciado o processo somente quando feita a citação do réu, ${ }^{233}$ o código de 1973 evoluiu em relação à matéria, prevendo em seus artigos 262 e 263 que se considera proposta a ação desde o despacho liminar do juiz na petição inicial ou de sua simples distribuição onde houver mais de um juiz. ${ }^{234}$

exemplo, por J. M. de Carvalho Santos: "o Codigo exige claramente: a) que, ao tempo da alienação, já pendesse contra o alienante uma demanda; b) que, em consequencia della, o devedor viesse a ficar insolvente. Quanto à insolvencia, deverá ser notoria ou haver motivos para ser conhecida pelo adquirente, nos contractos onerosos, tal como exige o Codigo Civil, para o exercicio da acção pauliana." (SANTOS, J. M. de Carvalho. Código de Processo Civil interpretado, cit, p. 39) e, já antes do regime do código de 1939, por Philadelpho Azevedo (Da fraude contra sentenças, cit., p. 22) e Jorge Americano (Da acção pauliana. 2. ed., São Paulo: Saraiva, 1932. p. 145 e ss.).

${ }^{233}$ Assim dispunham os artigos referentes à matéria no código revogado:

"Art. 196. A instância começará pela citação inicial válida e terminará por sua absolvição ou cessação ou pela execução da sentença.

"Art. 292. Feita a citação do réu, considerar-se-á proposta a ação, correndo, da entrega em cartório do mandado cumprido, o prazo de dez (10) dias para a contestação, observado o disposto no art. 33."

${ }^{234}$ Cf. "Art. 262. O processo começa por iniciativa da parte, mas se desenvolve por impulso oficial."

"Art. 263. Considera-se proposta a ação, tanto que a petição inicial seja despachada pelo juiz, ou simplesmente distribuída, onde houver mais de uma vara. A propositura da ação, todavia, só produz, quanto ao réu, os efeitos mencionados no art. 219 depois que for validamente citado."

A evolução só não foi completa porque o artigo 219 do código atual praticamente repetiu o texto do artigo 166 do código revogado, dando a entender que a litispendência, a prevenção do juízo, a litigiosidade da coisa, a constituição do devedor em mora e a interrupção da prescrição seriam efeitos não do despacho inicial ou distribuição, mas sim da citação, o que fazia sentido no sistema de 1939 e não no de 1973. Confira-se:

"Art. 166. A citação válida produz os seguintes efeitos: I. previne a jurisdição; II. induz litispendência; III. torna a coisa litigiosa; IV. constitue o devedor em mora; V. interrompe a prescrição.

$\S 1^{\circ}$ Quando ordenada por juiz incompetente, a citação só produzirá os efeitos previstos nos ns. IV e V deste artigo. (...)"

"Art. 219. A citação válida torna prevento o juízo, induz litispendência e faz litigiosa a coisa; e, ainda quando ordenada por juiz incompetente, constitui em mora o devedor e interrompe a prescrição."

Como visto no item 3.1, supra, essa leitura do artigo 219 é um dos argumentos nos quais o entendimento dominante se apoia para exigir também a má-fé do devedor para a configuração da fraude de execução.

No entanto, analisando de forma cuidadosa a norma prevista na última parte do artigo 263 transcrito acima, verifica-se que não é a "citação" que produz os efeitos mencionados no artigo 219, e sim a "propositura da ação" (o sujeito que se liga ao verbo "produz" nessa oração é "a propositura da ação" e não "a citação válida"). Colocada na ordem direta, o que essa norma diz é Todavia, a propositura da ação só produz os efeitos mencionados no art. 219 quanto ao réu depois que [este] for validamente citado. A conjunção adversativa "todavia", aqui prevista, indica que essa ideia se contrapõe a alguma outra que, no caso, está omissa (elipse). E o advérbio "só", também existente na norma, traduz o sentido de exclusão ou limitação, indicando que a ideia que está omissa é uma regra geral que está sendo limitada por esta. Por essa análise, a norma completa existente na segunda parte do artigo 263 seria: a propositura da ação produz os efeitos mencionados no art. 219, todavia, só os produz quanto ao réu depois que este for validamente citado. Estaria equivocada, portanto, a concepção generalizada de que, no código de 1973, os efeitos mencionados no artigo 219 também seriam "efeitos da citação", como no código anterior. 
Se o que torna pendente o processo é o seu início, ${ }^{235}$ e o próprio legislador, no sistema do código de 1973, desvinculou a propositura da ação do momento de citação do réu, haveria ainda maior razão para fazê-lo no tocante à fraude de execução. Ainda mais porque o código de 1973 também manteve, em seu artigo 251, a obrigatoriedade do registro de todos os processos, permitindo sua ciência pelos terceiros. ${ }^{236}$

Por fim, o inciso III do artigo 593 do CPC previa ainda que a fraude de execução iria ocorrer "nos demais casos expressos em lei”, analisados no item 2.3, supra.

Já na metade da década de 1980, mais uma alteração legislativa externa ao sistema do Código de Processo Civil veio interferir na questão da relevância do elemento subjetivo para a configuração da fraude de execução. Tratava-se da Lei n. ${ }^{\circ}$ 7.433, de 18 de dezembro de 1985, que, por assim dizer, positivou a diligência já costumeira de busca nos distribuidores forenses por ações pendentes em face do devedor. ${ }^{237}$

No entanto, a Lei n. ${ }^{\circ} 7.433 / 1985$ abordou a questão de forma oblíqua, pelo ângulo notarial, dispondo sobre "os requisitos para a lavratura de escrituras públicas":

"Art. $1^{\circ} \mathrm{Na}$ lavratura de atos notariais, inclusive os relativos a imóveis, além dos documentos de identificação das partes somente serão apresentados os documentos expressamente determinados nesta Lei. (...)

$\S 2^{\circ} \mathrm{O}$ Tabelião consignará no ato notarial, a apresentação do documento comprobatório do pagamento do Imposto de Transmissão inter vivos, as certidões fiscais, feitos ajuizados, e ônus reais, ficando dispensada a sua transcrição.

Em sentido semelhante, cf. Ronaldo Bretas de Carvalho Dias: "o processo, como visto, se inicia com o ajuizamento da ação, momento fixado nos apontados arts. 263 e 617, assim considerado para todos os fins, exceto, e exclusivamente, quanto ao réu, para os efeitos (únicos) do art. 219, nos quais não se inclui a configuração da fraude de execução." (DIAS, Ronaldo Bretas de Carvalho. Fraude no processo civil. Belo Horizonte: Del Rey, 1998. p. 114).

${ }^{235}$ Cf. Dinamarco: "processo pendente é o que já se iniciou e ainda não se extinguiu. Esse é o conceito elementar de litispendência (DINAMARCO, Cândido Rangel. As fraudes do devedor, cit., p. 442). Não obstante sustente tal ideia, o autor se filia ao entendimento dominante por reputar necessária a má-fé (ciência) do devedor, conforme visto no item 3.2, supra. Também Mário de Aguiar Moura entendia que "o diploma vigente simplificou a fixação do marco de início do processo, fazendo distinção apenas no que se refere ao problema prático da existência de um só juiz ou de mais de uma Vara" e, contudo, sustentava que "para o efeito estudado [requisitos da fraude de execução] é a citação que pesa." (MOURA, Mário Aguiar. Fraude de execução pela insolvência do devedor, cit., p. 301-302 - sem colchetes no original).

${ }^{236}$ "Art. 251. Todos os processos estão sujeitos a registro, devendo ser distribuídos onde houver mais de um juiz ou mais de um escrivão."

${ }^{237}$ Embora fosse tradicional na prática brasileira a diligência de obtenção de certidões negativas forenses, como relatava, já em 1920, Philadelpho Azevedo (cf. Da fraude contra sentenças, cit., p. 28-29), não havia dispositivo de lei regulamentando a matéria. 
$\S 3^{\circ}$ Obriga-se o Tabelião a manter, em Cartório, os documentos e certidões de que trata o parágrafo anterior, no original ou em cópias autenticadas."

Como se observa, o tratamento dado à matéria pela Lei n. $^{\circ} 7.433 / 1985$ gera dúvidas, uma vez que não deixa claro se a apresentação das certidões era obrigatória, constituindo "requisito para a lavratura da escritura" ou se a obrigatoriedade prevista na lei refere-se apenas à consignação de sua apresentação e ao seu arquivamento pelo tabelião.

No Estado de São Paulo, menos de um mês após a promulgação dessa lei, a Corregedoria Geral de Justiça do Tribunal de Justiça emitiu parecer concluindo pela facultatividade da apresentação das certidões, podendo o terceiro dispensá-las, assumindo o risco da pendência de ações em face do alienante. ${ }^{238}$

Regulamentando essa lei, em 9 de setembro de 1986, foi editado o Decreto n. ${ }^{\circ}$ 93.240, que acabou por restringir seu âmbito de aplicação, dispondo sobre a matéria da seguinte forma:

\footnotetext{
"Art $1^{\circ}$ Para a lavratura de atos notariais, relativos a imóveis, serão apresentados os seguintes documentos e certidões:

I - os documentos de identificação das partes e das demais pessoas que comparecerem na escritura pública, quando julgados necessários pelo Tabelião;

II - o comprovante do pagamento do Imposto sobre a Transmissão de Bens Imóveis e de Direitos a eles relativos, quando incidente sobre o ato, ressalvadas as hipóteses em que a lei autorize a efetivação do pagamento após a sua lavratura;

III - as certidões fiscais, assim entendidas:
}

\footnotetext{
238" Acerca da aplicação da Lei ${ }^{\circ} 7.433$, de 18 de dezembro de 1985, anote-se que no Estado de São Paulo, não traz grandes implicações. Dentre as exigências fixadas em lei, apenas a referente aos feitos ajuizados constitui novidade, direcionada à manifestação de vontade das partes, nas transações imobiliárias em que corriqueiramente são prejudicados. Visando, pois, o dever de apresentação das certidões à proteção da parte, constitui benefício de que pode livremente dispor, a seu critério. Basta lembrar hipótese de escritura de doação de bem imóvel feita pelo pai a seu filho. A confiança entre as partes, no caso, torna até inconcebível o dever de apresentar certidões. Mesmo se o outorgante afirmar a existência de ações poderá o outorgado dispensá-lo da exibição das certidões, assumindo, então, o risco pelos eventos futuros em prol da segurança negocial. Seria a defesa de um valor em detrimento de outro mais relevante. Se a pessoa capaz prefere arrostar as consequências de sua conduta incauta, o ordenamento jurídico não estará a criar-lhe obstáculo. O sistema legal não pode ser encarado de maneira a entravar os negócios, em prejuízo da própria economia nacional. Em conclusão, caso o outorgado dispense a apresentação das certidões relativas a feitos em trâmite, relativas ao imóvel, basta sua declaração expressa no corpo do ato para atendimento à determinação legal." (Parecer publicado no DJE de 17.01.86 e em Bol. AASP 1.415, de 29.01.86, p. 6-7).
} 
a) em relação aos imóveis urbanos, as certidões referentes aos tributos que incidam sobre o imóvel, observado o disposto no $\S 2^{\circ}$, deste artigo;

b) em relação aos imóveis rurais, o Certificado de Cadastro emitido pelo Instituto Nacional de Colonização e Reforma Agrária - INCRA, com a prova de quitação do último Imposto Territorial Rural lançado ou, quando o prazo para o seu pagamento ainda não tenha vencido, do Imposto Territorial Rural correspondente ao exercício imediatamente anterior;

IV - a certidão de ações reais e pessoais reipersecutórias, relativas ao imóvel, e a de ônus reais, expedidas pelo Registro de Imóveis competente, cujo prazo de validade, para este fim, será de 30 (trinta) dias;

$\mathrm{V}$ - os demais documentos e certidões, cuja apresentação seja exigida por lei.

$\S 1^{\circ} \mathrm{O}$ Tabelião consignará na escritura pública a apresentação dos documentos e das certidões mencionadas nos incisos II, III, IV e V, deste artigo.

$\S 2^{\circ}$ As certidões referidas na letra a, do inciso III, deste artigo, somente serão exigidas para a lavratura das escrituras públicas que impliquem a transferência de domínio e a sua apresentação poderá ser dispensada pelo adquirente que, neste caso, responderá, nos termos da lei, pelo pagamento dos débitos fiscais existentes.

$\S 3^{\circ} \mathrm{A}$ apresentação das certidões previstas no inciso IV, deste artigo, não eximirá o outorgante da obrigação de declararar na escritura pública, sob pena de responsabilidade civil e penal, a existência de outras ações reais e pessoais reipersecutórias, relativas ao imóvel, e de outros ônus reais incidentes sobre o mesmo.

Art $2^{\circ} \mathrm{O}$ Tabelião fica desobrigado de manter, em cartório, o original ou cópias autenticadas das certidões mencionadas nos incisos III e IV, do artigo $1^{\circ}$, desde que transcreva na escritura pública os elementos necessários à sua identificação, devendo, neste caso, as certidões acompanharem o traslado da escritura."

Verifica-se, assim, que as certidões de "feitos ajuizados" previstas no artigo $1^{\circ}, \S 2^{\circ}$, da Lei n. ${ }^{\circ} 7.433 / 1985$ foram limitadas pelo artigo $1^{\circ}$, IV, do Decreto n. ${ }^{\circ}$ 93.240/1986 à "certidão de ações reais e pessoais reipersecutórias, relativas ao imóvel", que, juntamente com a certidão "de ônus reais", seriam "expedidas pelo Registro de Imóveis competente", o que dava ensejo a interpretação que acabava por excluir da incidência da norma as certidões dos cartórios distribuidores forenses. ${ }^{239}$

\footnotetext{
${ }^{239}$ Sobre essa interpretação, cf. Décio Antonio Erpen: "não poderia ser o decreto mais feliz. Quem o elaborou compreendeu o sistema jurídico pátrio em sua plenitude e deu a exata dimensão que a publicidade registral merece. A certidão dos feitos ajuizados será emitida pelo Registro de Imóveis competente, para onde o
} 
Além disso, em seu artigo $2^{\circ}$, tal decreto isentava o tabelião da obrigação que lhe fora imposta no $\S 3^{\circ}$ do artigo $1^{\circ}$ da lei, de manter arquivadas as certidões apresentadas pelas partes, incluindo, em contrapartida, a obrigação de o alienante declarar, "sob pena de responsabilidade civil e penal", a existência "de outras ações reais e pessoais reipersecutórias relativas ao imóvel e de outros ônus reais incidentes sobre o mesmo".

A despeito da restrição de sentido que poderia decorrer das disposições do Decreto n. ${ }^{\circ}$ 93.240/1986, a jurisprudência tem interpretado a Lei n. ${ }^{\circ}$ 7.433/1985 como se ela efetivamente fizesse referência às certidões dos distribuidores forenses. ${ }^{240}$

Como se observa, essa legislação favorecia o entendimento que atribuía relevância ao elemento subjetivo na fraude de execução. Sua feição, contudo, era a má-fé do terceiro, decorrente do fato de esse poder saber da ação pendente pelas certidões dos distribuidores forenses.

Durante aproximadamente duas décadas, a disciplina da fraude de execução no sistema do Código de Processo Civil de 1973 permaneceu inalterada, convivendo com as disposições antes citadas das Leis n. ${ }^{\text {os }} 6.015 / 1973$ e 7.433/1985.

interessado deverá levar a notícia da demanda. Mais. Precisou a extensão da inscrição da demanda, ou seja, aquela relacionada com o imóvel, individualmente, tudo em atenção ao princípio da especialidade. Afastou as pessoais. Em momento algum a lei ou o regulamento falaram em negativa forense. Referiram-se à negativa fiscal, reduzindo o rol das indispensáveis: se o imóvel é urbano, somente as relativas ao imposto municipal incidente sobre o imóvel; se rural só a do INCRA. O rol é exaustivo." (ERPEN, Décio Antônio. A fraude à execução e a nova lei das escrituras públicas. Revista dos Tribunais, São Paulo, v. 76, n. 624, p. 40, out. 1987 - destaques no original) e Sérgio Jacomino "surpreenderia se eu dissesse que essas certidões são expedidas pelo registro de imóveis? Essas certidões - de publicidade de ações reais e pessoais reipersecutórias relativas ao imóvel e ônus reais - serão expedidas pelo registro de imóveis, onde, por força de lei, devem estar averbadas as circunstâncias e vicissitudes que afetem o imóvel ou os direitos a ele relativos, sob pena de ineficácia em relação ao terceiro adquirente ou credor (art. 169, LRP c.c. art. 167, I, 21). Notem o tempo verbal de expedidas, concordando com os tipos anteriores." (JACOMINO, Sérgio. A averbação premonitória, publicidade registral e distribuidores: a probatio diabolica e o santo remédio, cit., p. 20).

${ }^{240} \mathrm{Cf}$. "A certidão do distribuidor é obrigatória, nos termos da Lei 7.433/85, que indica os documentos mínimos necessários para a prática do ato notarial. O que ocorre, muitas vezes, é que o adquirente dispensa, como pode fazer, por sua conta e risco, a exibição do documento." (1º TAC-SP, $8^{\text {a }}$ Câm., MS 651.497-00/0, rel. Juiz Ruy Coppola, j. 21.09.00)

"A drástica consequência do reconhecimento da fraude à execução deve ser temperada pela exigência de prova, no mínimo rala, de que os terceiros 'conheciam ou deviam conhecer a constrição judicial', consoante ponderou a $4^{\mathrm{a}}$ Turma do STJ (REsp. 9.789-SP, 9.6.92, Rel. Min Athos Carneiro, DJU 3.8.92, p 11. 321) Assim, se o terceiro compra o bem diretamente do executado, razoável concluir que se desconhecia a execução, ao menos deveria conhecê-la, pois tinha plenas condições de exigir do vendedor a exibição de certidão de distribuições de ações e execuções judiciais, máxime com o advento da Lei 7.433/85, regulamentada pelo Decreto 93. 240/86." (TJSP, 24a Câm. de Dir. Priv., Apel. 955.644-5, rel. Des. Luis Carlos de Barros, j. 14.03.06). Também essa a interpretação seguida pelos acórdãos dos REsps. 655.000/SP, 618.625/SC e 751.481/RS, julgados em 2007 e 2008 em sentido diverso ao que constou da Súmula 375. 
No entanto, o descompasso existente entre essas normas alimentava cada vez mais a divergência quanto à relevância do elemento subjetivo, ao ponto de DécıO ANTONIO ERPEN afirmar, em 1991, que "nós Juízes, à guisa de prestigiarmos nossa própria atividade, transformamos a compra e venda numa autêntica roleta jurídica."241

O principal foco da divergência era - conforme visto - a relevância que se deveria atribuir ao registro da penhora, previsto no artigo 240 da Lei n. ${ }^{\circ} 6.015 / 1973$. E foi com base em tese sugerida pelo mesmo DÉCIO ANTONIO ERPEN, no VI Encontro de Tribunais de Alçada, realizado em Belo Horizonte em junho de 1983, que se fez a primeira das três reformas pelas quais passou o artigo 659 do Código de Processo Civil. ${ }^{242}$

Tal reforma operou-se por força da Lei n. ${ }^{\circ}$ 8.935, de 13 de dezembro de 1994, que alterou, nesse ponto, a situação existente desde 1939. O registro da penhora, que originalmente estava previsto no artigo 266 do Decreto n. ${ }^{\circ}$ 18.542/1928, ligando-se, na forma sugerida por PHILADELPHO AZEVEDO, à hipótese de fraude de execução decorrente da alienação de bem penhorado, e fora repetido nos artigos 280 do Decreto n. ${ }^{\circ}$ 4.857/1939 e 240 da Lei n. ${ }^{\circ}$ 6.015/1973 sem possuir dispositivo correspondente na legislação processual, passava a encontrar eco no $\S 4^{\circ}$ do artigo 659 do CPC.

Contudo, em vez de reintroduzir no código a hipótese de fraude de execução decorrente da alienação de bem penhorado, restabelecendo o liame original entre a legislação processual e a registrária, o legislador de 1994 inovou em relação à matéria.

\footnotetext{
${ }^{241}$ ERPEN, Décio Antônio. A fraude à execução e o desprestígio da função jurisdicional. Revista dos Tribunais, São Paulo, v. 80, n. 672, p. 80-89, out. 1991. Nesse artigo, o autor sustentava a importância de se dar prevalência ao registro imobiliário dos atos processuais - sobretudo da penhora, com base no artigo 240 da Lei n. ${ }^{\circ}$ 6.015/1973 - para a configuração da fraude de execução, relegando para plano quase irrelevante a cautela tradicional de se obter certidões negativas forenses do alienante, dada a sua patente falibilidade.

${ }^{242}$ Cf., NERY JR., Nelson. Atualidades sobre o processo civil. São Paulo: Ed. Revista dos Tribunais, 1995. p. 115. A tese de Décio Antonio Erpen aqui mencionada é a de $n .^{\circ} 9$ daquele encontro, sendo aprovada por maioria, nos seguintes termos: "necessidade de registro da penhora para surtir efeitos frente a terceiros de boa-fé." (cf. RT 580/301). Parece-nos, contudo, que a alteração legislativa baseou-se, também, nas conclusões apresentadas por Sálvio de Figueiredo Teixeira em artigo já citado nesta tese, publicado em 1986, como se observa das conclusões de n. ${ }^{\text {os }} 15.31$ a 15.33 :

"15.31. De lege ferenda, seria conveniente que o legislador adotasse o sistema europeu, segundo o qual a penhora somente se aperfeiçoa com a apreensão, o depósito e o registro, acautelando-se, porém, contra o valor exorbitante dos emolumentos respectivos.

15.32. Seria salutar que, mesmo em face da legislação atual, na qual se harmonizam as leis processual e registral, se implantasse a mentalidade de que é de toda conveniência a inscrição.

15.33. O interesse geral, representado pelo anseio de infundir segurança aos negócioas jurídicos, impõe que se reforce o princípio da publicidade e se prestigie a boa-fé, que é o elemento que informa, estrutura e vivifica todas as relações e sobre o qual repousa o nosso Direito." (TEIXEIRA, Sálvio de Figueiredo. Fraude de execução, cit., p. 13).
} 
No lugar de simples meio de publicidade, para possibilitar o conhecimento por terceiros, o registro foi previsto no $\S 4^{\circ}$ do art. 659 como verdadeiro elemento constitutivo da penhora:

“Art. 659. Se o devedor não pagar, nem fizer nomeação válida, o oficial de justiça penhorar-lhe-á tantos bens quantos bastem para o pagamento do principal, juros, custas e honorários advocatícios. (...)

$\S 4^{\circ}$ - A penhora de bens imóveis realizar-se-á mediante auto ou termo de penhora e inscrição no respectivo registro."

Vale dizer, pela literalidade da norma, o imóvel só estaria penhorado após o registro do termo ou do auto de penhora no cartório imobiliário, tal qual o sistema italiano $^{243}$ e de forma diversa da prevista no sistema português da época que, segundo se sustentava, seria mais compatível com o brasileiro. ${ }^{244}$

A alteração foi aplaudida apenas por pequena parcela da doutrina, que, como DÉcio ANTONio ERPEn, defendia a exclusividade do registro imobiliário como fonte de informações para a verificação da ocorrência da fraude de execução. Entre esses autores, encontra-se WALTER CENEVIVA, que, comentando os artigos 169 e 240 da Lei de Registros Públicos logo após a reforma do Código de Processo Civil, afirmava: "o registro imobiliário é obrigatório (art. 169). A penhora não registrada é inoponível a terceiro que, no curso da ação, adquira o imóvel penhorado (...) Se o credor omite o dever legal de

${ }^{243}$ Observe-se a semelhança com a parte inicial do artigo 555 do Código de Processo Civil italiano, que trata da penhora de bens imóveis:

"Art. 555 Forma del pignoramento. Il pignoramento immobiliare si esegue mediante notificazione al debitore e successiva trascrizione di un atto nel quale gli si indicano esattamente, con gli estremi richiesti dal codice civile per la individuazione dell'immobile ipotecato, i beni e i diritti immobiliari che si intendono sottoporre a esecuzione, e gli si fa l'ingiunzione prevista nell'articolo 492. Immediatamente dopo la notificazione l'ufficiale giudiziario consegna copia autentica dell'atto con le note di trascrizione al competente conservatore dei registri immobiliari, che trascrive l'atto e gli restituisce una delle note. Le attivita' previste nel comma precedente possono essere compiute anche dal creditore pignorante, al quale l'ufficiale giudiziario, se richiesto, deve consegnare gli atti di cui sopra." (CARPI, Federico; COLESANTI, Vittorio; TARUFFO, Michele. Commentario breve al Codice di Procedura Civile. 4. ed. Milano: Cedam, 2002. p. $555)$.

${ }^{244}$ A doutrina referia-se à norma do artigo $838^{\circ}, 3$, do Código de Processo Civil português que assim dispunha na época:

"Art. $838^{\circ}$ - (Efectivação da penhora de imóveis) (...)

3. Em relação a terceiros, a penhora só produz efeitos desde a data do registo, o qual terá por base uma certidão do respectivo termo.

Ao processo juntar-se-á certificado do registo e certidão dos ónus que incidam sobre os bens abrangidos pela penhora."

Posteriormente, contudo, a disciplina portuguesa veio a sofrer alteração tanto pelo Decreto n. ${ }^{\circ}$ 329-A/95, quanto pelo Decreto n. ${ }^{\circ}$ 375-A/99, que acabaram por atribuir maior relevância ao registro, inclusive atribuindo-lhe o efeito de suspender a execução em razão da sua ausência (cf. João Paulo Remédio Marques, A Penhora e a Reforma do Processo Civil, Lisboa: Lex, 2000, p. 38). 
registrar e se mostra desatento ao resguardo do seu direito, sofre a consequência, sendo absurdo transferi-la ao terceiro, inviabilizando a finalidade mesma do sistema registrário. (...) É inaceitável a corrente exegética segundo a qual, feito o negócio pertinente a imóvel, o adquirente tem o dever de obter prévias certidões forenses esclarecedoras da situação do alienante. (...) Com esse caminho introduz-se uma quebra inaceitável do sistema: afasta-se a predominância do direito real e se dá realce ao pessoal, inerente à penhora não registrada. É interpretação contrária à letra do art. 240. Deste resultado a afirmação positiva de que só o registro da penhora faz prova, quanto à fraude, de transação posterior e de que, ao contrário, inexistente o registro, não se a pode alegar, por força da lei." 245

A maioria da doutrina, no entanto, não recebeu bem o novo dispositivo, como se vê pela manifestação de CARLOS AlBERTo CARMONA: "ao acrescentar o $\S 4^{\circ}$ ao art. 659 do Código de Processo Civil, cometeu o legislador pecado imperdoável. Ouso dizer que, se algum dispositivo legal introduzido pela Lei n. 8.953/94 merece crítica incisiva, tal dispositivo é exatamente o do parágrafo indigitado. A intenção do reformador foi louvável (...) O remédio encontrado, porém, empregou a fórmula errada."246

Houve autores, ainda, que, valendo-se das razões constantes da exposição de motivos do projeto de lei em que se inseria esse dispositivo, interpretavam-no contra sua expressão literal, defendendo que o registro representava mera condição de publicidade para terceiros e não elemento integrante da penhora. Nesse sentido, DinAmARCO sustentava que "na justificativa do projeto que se converteu na lei n. 8.953 (proj. de lei n. 3.810-A, da Câmara dos Deputados) ficou expressamente declarada a intenção com que essa exigência se positivava: "prevenir futuras demandas com alegações de fraude de execução, como tão frequentemente ocorre na prática forense atual.' Dada a sua finalidade em relação a terceiros, essa exigência não pode ser interpretada como formalidade essencial à existência do ato jurídico penhora. (...) Só poderá não ser eficaz em relação a terceiros. Aí está a grande importância da inovação trazida nesse novo parágrafo: sem ter

\footnotetext{
${ }^{245}$ CENEVIVA, Walter. Lei de Registros Públicos comentada. 10. ed. São Paulo: Saraiva, 1995. p. 356 e 445. ${ }^{246}$ CARMONA, Carlos Alberto. O processo de execução depois da reforma. In: TEIXEIRA, Sálvio de Figueiredo (Coord.), Reforma do Código de Processo Civil. São Paulo: Saraiva, 1996. p. 759. Também Clito Fornaciari Júnior: "o dispositivo feriu o princípio da publicidade do processo, exigindo uma publicidade a mais, que vem a ser a do registro imobiliário. Antes do registro, a penhora não está realizada, segundo a lei. Sendo assim, a intimação da penhora, de onde começa a fluir o prazo para o oferecimento dos embargos, somente poderá ser feita após o registro. Da mesma forma, somente com esse ato se tem a vinculação de determinado bem do devedor para a solução do débito." (FORNACIARI JÚNIOR, Clito. $A$ reforma do Código de Processo Civil. São Paulo: Saraiva, 1996. p. 177).
} 
sido feito o registro, aquele que adquirir o bem presume-se não ter conhecimento da pendência de processo capaz de reduzir o devedor à insolvência." ${ }^{, 47}$

Nota-se também nessa lição de DiNAMARCO a mudança da feição da máfé do terceiro: não mais se fala da mera existência de razão para saber da ação pendente, mas sim em sua efetiva ciência da pendência da ação, se inexistente o registro da penhora.

A jurisprudência continuava oscilando, mas a inclusão desse novo $\S 4^{\circ}$ no artigo 659 do Código de Processo Civil também fortaleceu a corrente que, já com base no artigo 240 da Lei de Registros Públicos, sustentava que a ausência do registro acarretava para o credor o ônus de provar que o terceiro tinha ciência da pendência da ação que poderia reduzir o devedor à insolvência para a configuração da fraude de execução. ${ }^{248}$

${ }^{247}$ DINAMARCO, Cândido Rangel. A reforma do Código de Processo Civil. 3. ed. São Paulo: Malheiros, 1996. p. 299. Também defendiam posição análoga Donaldo Armelin (O processo de execução e a reforma do Código de Processo Civil. In: TEIXEIRA, Sálvio de Figueiredo (Coord.), Reforma do Código de Processo Civil. São Paulo: Saraiva, 1996. p. 708) e Fátima Nancy Andrighi, escrevendo essa última que "o ato do registro da penhora visa a dar conhecimento, a terceiro, de estar aquele bem à disposição da Justiça, pendendo sobre ele gravame. (...) Com a nova regra, fica definida a fraude de execução, pois, conforme o disposto no art. 240 da Lei de Registros Públicos, 'o registro da penhora faz prova contra qualquer transação posterior'. A adoção do entendimento pretoriano que presume a fraude de execução quando o ato de alienação, ou oneração, ocorra após a penhora, considerando atentatório à dignidade da Justiça, por tornar inócuos seus atos, sem tecer maiores questionamentos é passível de causar injustiças, pois a ausência do registro da penhora, ainda se a alienação ocorreu após o gravame, impossibilita que o adquirente tenha informações seguras a respeito do desembaraço do imóvel." (ANDRIGHI, Fátima Nancy. O Registro da penhora e a reforma do Código de Processo Civil. In: TEIXEIRA, Sálvio de Figueiredo (Coord.), Reforma do Código de Processo Civil. São Paulo: Saraiva, 1996. p. 811-812).

${ }^{248}$ Essa foi a corrente que passou a prevalecer, principalmente no Superior Tribunal de Justiça, como afirma o Min. Teori Albino Zavascki em um dos precedentes que deram origem à súmula 375: "em nossa lei processual, a determinação de registro da penhora de bem imóvel surgiu, formalmente, com a inclusão, pela Lei 8.953/94, do $\S 4^{\circ}$ ao art. 659. Entretanto, mesmo antes disso, a jurisprudência já considerava que o registro constituía prova segura e suficiente para elidir a presunção de boa-fé do adquirente do bem imóvel penhorado. Nesse sentido, aliás, dispunha o art. 245 da Lei 6.015/73 (a inscrição da penhora faz prova quanto à fraude de qualquer transação posterior). A esse respeito, a jurisprudência desta Corte consolidouse no sentido de que, ante a ausência do registro da penhora, para que seja caracterizada fraude à execução, impõe-se ao credor o ônus de provar que o adquirente tinha ciência da constrição que pesava sobre o imóvel." (STJ, $1^{\text {a }}$ T., REsp. 865.974/RS, rel. Min. Teori Albino Zavascki, j. 02.09.08 - a menção ao artigo 245 refere-se à numeração antiga da Lei n. ${ }^{\circ}$ 6.015/1973). Cf. também outros acórdãos aplicando o novo dispositivo: "para a caracterização da fraude de execução, relativa à alienação de bem constrito, é indispensável a inscrição do gravame no registro competente, cabendo ao exeqüente, na ausência desse registro, provar que o terceiro adquirente tinha ciência do ônus que recaía sobre o bem." (STJ, $4^{\mathrm{a}}$ T., REsp. 186.633/MS, $4^{\mathrm{a}}$ T., rel. Min. Sálvio de Figueiredo Teixeira, j. 29.10.98); "não basta para a configuração da fraude à execução a existência, anteriormente à venda de imóvel, de execução movida contra o alienante, somente se admitindo tal situação se já tivesse, antes, a inscrição da penhora no cartório competente, salvo se inequívoco o conhecimento dos adquirentes sobre a pendência judicial, prova que incumbe ao credor trazer." (STJ, $2^{a}$ Seção, REsp. 442.583/MS, rel. Min. Aldir Passarinho Junior, j. 27.11.02); "nos termos do art. 659 do CPC, na redação que lhe foi dada pela Lei n. 8.953/94, exigível a inscrição da penhora no cartório de registro imobiliário para que passe a ter efeito erga omnes e, nessa circunstância, torne-se impeditiva da venda a terceiros, em fraude de execução. Caso em que, à míngua de tal requisito, a alienação é eficaz, autorizando-se o uso de embargos de terceiro em defesa da titularidade sobre o imóvel pelos adquirentes.” (STJ, $4^{\mathrm{a}}$ T., REsp. 557.358/MG, rel. Min. Aldir Passarinho Junior, j. 18.03.04). 
Em 2002, já prevalecendo, tanto na doutrina quanto na jurisprudência, ${ }^{249}$ a posição de que o registro não era ato integrativo da penhora de imóveis, e sim mera condição para a presunção de seu conhecimento por terceiros, o legislador, por meio da Lei n. ${ }^{\circ} 10.444$, de 7 de maio daquele ano, alterou a redação do $\S 4^{\circ}$ no artigo 659 do Código de Processo Civil, adequando-a a este entendimento: $:^{250}$

\begin{abstract}
“Art. 659. Se o devedor não pagar, nem fizer nomeação válida, o oficial de justiça penhorar-lhe-á tantos bens quantos bastem para o pagamento do principal, juros, custas e honorários advocatícios. (...)

$\S 4^{\circ}$ - A penhora de bens imóveis realizar-se-á mediante auto ou termo de penhora, cabendo ao exeqüente, sem prejuízo da imediata intimação do executado (art. 669), providenciar, para presunção absoluta de conhecimento por terceiros, o respectivo registro no registro imobiliário, mediante apresentação de certidão de inteiro teor do ato e independentemente de mandado judicial."
\end{abstract}

Sobre tal alteração, assim se manifestou DinAMARCO: “o que há de mais importante no dispositivo é a cláusula para presunção absoluta de conhecimento de terceiros, a qual a um só tempo indica que essa presunção existirá e será absoluta, e também que a finalidade do registro é essa e não outra. Assim, a) feito o registro, a nenhum terceiro será útil alegar desconhecimento da penhora feita, sendo esta oponível erga omnes e portanto fazendo ineficaz eventuais alienações que causem ou agravem a insolvência do executado (fraude de execução - art. 592, inc. V, c/c 593, inc. II); b) não feito o registro, nem por isso fica o adquirente a salvo das consequências da fraude de

\footnotetext{
${ }^{249}$ No âmbito doutrinário, além dos autores já citados, cf. Paulo Henrique dos Santos Lucon: "em Portugal, como no Brasil, o registro não é formalidade indispensável à efetivação da penhora, mas consoante o disposto no art. 838, 4, do CPC português, 'em relação a terceiros, a penhora só produz efeitos desde a data do registro, o qual terá por base uma certidão do respectivo termo'." (LUCON, Paulo Henrique dos Santos. Fraude à execução, responsabilidade processual civil e registro da penhora, cit., p. 140-141). Na jurisprudência, cf. "da interpretação sistemática dos artigos 659, parágrafo 4º 669 e 738, inciso I, do Código de Processo Civil, resulta que a inscrição do auto/termo no cartório de registro de imóveis não consubstancia ato integrativo da penhora, mas, sim, 'ato independente a ser praticado, a posteriori, pelo credor'." (STJ, 6 ${ }^{\mathrm{a}}$ T., REsp. 153.793/SP, rel. Min. Hamilton Carvalhido, j. 20.11.01).

${ }^{250}$ Assim dizia a exposição de motivos do Projeto de Lei n. ${ }^{\circ} 144 / 01$ para fundamentar essa alteração: "o atual Art. $659, \S 4^{\circ}$, resultante da Lei 8.953 , de 13.12 .94 , de alto alcance na prevenção das fraudes e no resguardo dos direitos de terceiros de boa-fé que venham a adquirir imóvel já penhorado, suscita no entanto relevante dúvida: se o registro da penhora é 'integrativo' do próprio ato complexo, o prazo para embargos somente terá início após tal registro; se, todavia, é requisito de eficácia, para oponibilidade da penhora perante terceiros, a intimação da penhora deverá fazer-se logo após lavrado o auto respectivo. Na trilha da doutrina e da jurisprudência majoritárias, o projeto dilucida tal controvérsia, adotando a segunda orientação: a exigência do registro não impede a imediata intimação do executado, constituindo-se o registro em condição de eficácia plena da penhora perante os terceiros, cabendo ao exeqüente as devidas providências junto ao ofício imobiliário."
} 
execução, porque seu conhecimento não é presumido de modo absoluto mas o autor pode sempre prová-lo."251

Coincidência ou não, é interessante notar que, nesse mesmo ano de 2002, a norma que exigia a necessidade de registro para que o direito do credor de prosseguir na execução contra terceiros mediatos - existente, como visto, desde 1864 e então prevista no artigo 824 do Código Civil de 1916 - foi suprimida do ordenamento jurídico, uma vez que não foi repetida pelo Novo Código Civil instituído pela Lei n. ${ }^{\circ}$ 10.406/2002.

Além disso, também nesse mesmo ano, a $2^{\text {a }}$ Seção do Superior Tribunal de Justiça reviu seu posicionamento antes fixado no EDREsp 114.415/MG. Assim, no Recurso Especial 442.583/MS, julgado em 27 de novembro de 2002, sob a relatoria do Ministro Aldir Passarinho Júnior, a $2^{\text {a }}$ Seção do Superior Tribunal de Justiça passou a entender que o registro da penhora - ou a necessidade de prova pelo credor da ciência do terceiro quanto à pendência da ação - era requisito necessário para a configuração da fraude de execução, ainda que se tratasse de aquisição por terceiros imediatos. ${ }^{252}$

Tal entendimento passou a predominar na jurisprudência do Superior Tribunal de Justiça, sendo aplicado principalmente em casos de bens alienados antes da penhora, ${ }^{253}$ em que o registro da pendência da ação no cartório imobiliário sequer seria possível nesse momento, ensejando críticas por parte da doutrina.

Nesse sentido, a manifestação de ARAKEN DE ASSIS: "o termo inicial dos atos ineficazes flui da citação do obrigado, em 'demanda capaz de reduzi-lo a insolvência' (art. 593, II), bem antes da penhora, o que revela a insensatez da controvérsia sobre a obrigatoriedade do registro da penhora." 254

\footnotetext{
${ }^{251}$ DINAMARCO, Cândido Rangel. A reforma da reforma. São Paulo: Malheiros, 2002. p. 269-270.

${ }^{252}$ Diferentemente do acórdão do EREsp. 114.415/MG, que fora unânime, no REsp. 442.583/MS, restaram vencidos a ministra Nancy Andrighi e o relator sorteado, o ministro Carlos Alberto Menezes Direito, declarando esse último em seu voto que "se a compra é feita diretamente do executado, as certidões necessárias para a realização da transferência da propriedade indicarão a existência da ação de execução distribuída, autorizando o comprador a apurar melhor a a situação do bem a ser adquirido. Quando a venda não é feita diretamente do executado, mas, sim, de terceira pessoa, é evidente que as certidões de distribuição não registrarão aquela ação em que figura como réu o antecedente na cadeia sucessória, deixando o adquirente na impossibilidade de constatar a presença de pendência executiva contra o vendedor."

${ }^{253} \mathrm{Cf}$. aqui, também, as pesquisas jurisprudenciais realizadas nesta tese, cujos relatórios encontram-se em seus Apêndices 1 e 2.

${ }^{254}$ ASSIS, Araken de. Manual do processo de execução,cit., p. 455.
} 
Em 2006, na terceira fase da reforma do processo de execução, o legislador interferiu na disciplina da matéria e, por meio da Lei n. ${ }^{\circ} 11.382$, de 6 de dezembro daquele ano, modificou novamente o $§ 4^{\circ}$ do artigo 659 do Código de Processo Civil e inseriu um novo $\S 6^{\circ}$ nesse mesmo artigo, que passou a ter a seguinte redação:

“Art. 659 A penhora deverá incidir em tantos bens quantos bastem para o pagamento do principal atualizado, juros custas e honorários advocatícios. ${ }^{255}(\ldots)$

$\S 4^{\circ}$ A penhora de bens imóveis realizar-se-á mediante auto ou termo de penhora, cabendo ao exeqüente, sem prejuízo da imediata intimação do executado (art. 652, $\S 4^{\circ}$ ), providenciar, para presunção absoluta de conhecimento por terceiros, a respectiva averbação no ofício imobiliário, mediante a apresentação de certidão de inteiro teor do ato, independentemente de mandado judicial. (...)

$\S 6^{\circ}$ Obedecidas as normas de segurança que forem instituídas, sob critérios uniformes, pelos Tribunais, a penhora de numerário e as averbações de penhoras de bens imóveis e móveis podem ser realizadas por meios eletrônicos."

No que diz respeito à norma do $\S 4^{\circ}$ a alteração foi apenas a substituição do termo "registro" por "averbação", tornando mais simples e menos custosa a forma pela qual se dá publicidade ao ato constritivo. Falhou, no entanto, o legislador em não atentar para a necessidade de se alterar também a Lei n. ${ }^{\circ}$ 6.015/1973, que permaneceu prevendo a penhora entre os atos passíveis de registro e não de averbação (cf. art. 167, I, 5). ${ }^{256}$

Já a norma do novo $\S 6^{\circ}$ contém duas novidades. Em primeiro lugar, e de forma mais visível, permite que a averbação da penhora atualmente seja feita por meios eletrônicos, na linha do que prevê a Lei n. ${ }^{\circ} 11.419$, de 19 de dezembro de 2006. Em segundo lugar, e de forma mais sutil, o novo $\S 6^{\circ}$ ampliou os limites do $\S 4^{\circ}$, permitindo também a "averbação" da penhora em registros públicos de bens móveis, como veículos automotores, embarcações, cotas ou ações de sociedades etc.

\footnotetext{
${ }^{255}$ Como se observa, o caput do artigo também foi ligeiramente alterado para adaptar-se ao novo procedimento da execução criado por essa lei. Tal alteração, no entanto, não tem grande relevância para o objeto desta tese.

${ }^{256}$ Nesse sentido, cf. BUENO, Cassio Scarpinella. A nova etapa da reforma do Código de Processo Civil. São Paulo: Saraiva, 2007. v. 3, p. 138-139 e LEONEL, Ricardo de Barros. Reformas recentes do processo civil, São Paulo: Método, 2007. p. 76. Tal alteração de registro para averbação afigura-se um tanto contraditória com a promovida pela mesma Lei n. ${ }^{\circ} 11.382 / 2006$ no artigo 698 do CPC, em que equiparou o credor com penhora averbada ao credor hipotecário e ao senhorio direto para fins de ser intimado da realização da adjudicação ou alienação do bem.
} 
Nesse ponto, pode parecer que há certa contradição entre os $\S \S 4^{\circ}$ e $6^{\circ}$ do artigo 659, já que o primeiro prevê apenas "averbação no ofício imobiliário" e o segundo menciona a possibilidade de averbação de bens móveis. No entanto, a opção do legislador pela averbação em registro de bens móveis também é confirmada pela inclusão, pela mesma lei, do artigo 615-A, que assim dispõe:

\begin{abstract}
“Art. 615-A. O exeqüente poderá, no ato da distribuição, obter certidão comprobatória do ajuizamento da execução, com identificação das partes e valor da causa, para fins de averbação no registro de imóveis, registro de veículos ou registro de outros bens sujeitos a penhora ou arresto. (...)

$\S 3^{\circ}$. Presume-se em fraude à execução a alienação ou oneração de bens efetuada após a averbação (art. 593).”
\end{abstract}

Tal artigo já surgiu envolto em polêmica, havendo alguns autores que sustentam que ele teria criado uma nova hipótese de fraude de execução, além das já existentes no artigo 593 do Código de Processo Civil. ${ }^{257}$ Contudo, não parece ser esse o melhor entendimento, pois o referido artigo 615-A limita-se a prever a possibilidade de averbação de um ato processual nos registros públicos, com o intuito de lhe agregar maior publicidade, tal qual já faziam os artigos 240 da Lei n. ${ }^{\circ} 6.015 / 1973$ e o $§ 4^{\circ}$ do artigo 659 do Código de Processo Civil em sua redação dada pelas reformas de 2002 e $2006 .{ }^{258}$

\footnotetext{
${ }^{257}$ Cf. Araken de Assis: "segundo o art. 615-A, § $3^{\circ}$, a alienação ou oneração de bens efetuada após a averbação presume-se fraudulenta. Para evitar dúvidas, o parágrafo faz remissão ao art. 593, subentendendo-se que a referência é ao inc. III, o único concebível. Trata-se, portanto, de outro caso 'expresso em lei', em que há fraude contra a execução." (ASSIS, Araken de. Manual da execução. 12. ed. São Paulo: Ed. Revista dos Tribunais, 2009. p. 287). Também nesse sentido, Ricardo Chemale Selistre Peña (Fraude à execução, cit., p. 109); SALAMACHA, José Eli. Fraude à execução no direito comparado e a nova modalidade de fraude à execução do art. 615-A do CPC. Revista de Direito Privado, São Paulo, n. 32, p. 92, out./dez. 2007) e MOLLICA, Luciano. Novos contornos para a fraude de execução na alienação de bem imóvel, sob a perspectiva de dinamizar os negócios imobiliários. 2009. Tese (Doutorado). Faculdade de Direito, Universidade de São Paulo, São Paulo, 2009. p. 196.

${ }^{258}$ Nesse sentido, Décio Antonio Erpen: "o art. 240 da Lei n. ${ }^{\circ} 6.015$ tem a seguinte redação: 'o registro da penhora faz prova quanto à fraude de qualquer transação posterior.' Já no art. 615-A, em seu $\S 3^{\circ}$, é disposto: 'presume-se em fraude à execução a alienação ou oneração de bens efetuada após a averbação (art. 593).' Ambos os artigos dizem respeito à prova pré-constituída da fraude, independente de maiores perquirições." Mais adiante, complementa deixando claro que tal prova serve também para a ciência do devedor, ao afirmar que, "com os novos preceitos, parece se esvaziar a indagação, para configurar a fraude à execução, a data do ajuizamento da ação, se da distribuição ou da citação. O que vinga, agora, é a data da averbação da execução." (ERPEN, Décio Antônio. Das novas regras da execução e o registro imobiliário: da reserva de prioridade: do bloqueio registral da Lei 11.382/2006 - artigo 615-A. Revista IOB de Direito Civil e Processual Civil, n. 53, maio/jun. 2008. p. 14 e 15, respectivamente). No mesmo sentido, cf. Gledson Marques de Campos e Marcos Destefani: "como o STJ tem exigido a presença do elemento subjetivo, representado no conhecimento da ação por parte do adquirente, para a caracterização de fraude de execução, a certidão, ao menos, afasta essa necessidade, residindo aí a utilidade do art. 615-A para a fase de cumprimento de sentença." (CAMPOS, Gledson Marques de; DESTEFANI, Marcos. O novo art. 615-A e a fraude de execução. Revista Dialética de Direito Processual, São Paulo, n. 60, p. 62, mar. 2008).
} 
Para outros autores, o artigo 615-A teria concentrado no registro imobiliário as formas de ciência de terceiro quanto às ações pendentes, dispensando-o da diligência de fazer a busca nos distribuidores forenses. ${ }^{259}$ Contudo, tal interpretação restou superada - ao menos no Estado de São Paulo - pelo pronunciamento da Corregedoria Geral da Justiça no Processo CG n 204/2007 que, à luz da jurisprudência que se formara sobre o tema, necessidade de obtenção das certidões dos distribuidores forenses para caracterizar a boa-fé dos terceiros adquirentes. ${ }^{260}$

Outra interessante discussão que se estabeleceu sobre o novo dispositivo diz respeito à sua aplicação aos casos de execução de título judicial. Embora o artigo 615A tenha sido inserido pela Lei n. ${ }^{\circ} 11.382 / 2006$ no Livro II do CPC, reservado ao processo de execução dos títulos extrajudiciais, na doutrina tem prevalecido o entendimento de que

\footnotetext{
${ }^{259} \mathrm{Cf}$., nesse sentido, JACOMINO, Sérgio. A averbação premonitória, publicidade registral e distribuidores: a probatio diabolica e o santo remédio, cit., p. 20; e Marcelo Augusto Santana de Melo, afirmando esse último que: "ao introduzir em nosso direito a averbação premonitória fixando e aclarando as hipóteses de fraude de execução, um efeito automático e lógico é a desnecessidade de apresentação de certidões dos distribuidores cíveis e fiscais prevista na lei 7.433/85 e decreto 93.240/86". (MELLO, Marcelo Augusto Santana de. A averbação premonitória introduzida pela Lei 11.382/2006. Boletim do IRIB em Revista, n. 331, p. 36, abr./jun. 2007).

${ }^{260} \mathrm{Cf}$. "instaurou-se, entre os notários e registradores de imóveis, dúvida a respeito da vigência do disposto no art. $1^{\circ}, \S 2^{\circ}$, da Lei n. $7.433 / 1985$, no que concerne à exigência pelo tabelião, para a prática de atos notariais, de apresentação de certidões de "feitos ajuizados", vale dizer, de certidões dos distribuidores judiciais, a partir da entrada em vigor da Lei n. 11.382/2006, a qual introduziu alterações no Código de Processo Civil, no tocante ao processo de execução fundada em títulos extrajudiciais. Isso porque, de acordo com o entendimento de alguns especialistas da área do direito registral, a possibilidade de averbação do ajuizamento da demanda no registro de imóveis (art 615-A do CPC, introduzido pelo art. $2^{\circ}$ da Lei n. 11.382/2006), teria tornado dispensável a apresentação das referidas certidões para a lavratura de escrituras públicas relacionadas a imóveis, verificando-se derrogação, nessa parte, da Lei n. 7.433/1985. Contudo, há que se anotar, na esteira da orientação firmada pelos eminentes Desembargadores da $32^{a}$ Câmara da Seção de Direito Privado do Egrégio Tribunal de Justiça, que a inovação introduzida no Código de Processo Civil pela Lei n. 11.382/2006 diz respeito, em um primeiro momento, às ações de execução fundadas em título extrajudicial ou, eventualmente, admitida uma interpretação mais ampla, às hipóteses de cumprimento de sentença, como fase subsequente à fase de conhecimento do processo judicial. Não tem pertinência, ao menos em princípio, a todas as demandas, ainda na fase de conhecimento, cujo ajuizamento pode igualmente autorizar o reconhecimento de fraude de execução na alienação ou oneração de bens pelo devedor a terceiros. Assim, prossegue útil e necessária a apresentação de certidões dos distribuidores judiciais para a lavratura de escrituras relativas a imóveis, a fim de resguardar, tanto quanto possível, o adquirente contra futura ineficácia do ato em face de execução que se vier a instaurar. (...) Aprovo o parecer do MM. Juiz Auxiliar da corregedoria e por seus fundamentos, que adoto acolho o requerimento formulado pelos Excelentíssimos Senhores Desembargadores Francisco Occhiuto, Junior, Kioitsi Chicuta, Ruy Coppola e Sidney Rocha de Souza, com expedição de comunicado endereçado aos notários e registradores do Estado de São Paulo, no tocante à necessidade de serem exigidas certidões dos distribuidores judiciais para a lavratura de escrituras relativas à alienação ou oneração de bens imóveis, à luz do disposto no art. $1^{\circ}, \S 2^{\circ}$, da Lei $n^{\circ} 7.433 / 1985$, não derrogado pela Lei $n^{\circ} 11.382 / 2006$. (Parecer n. ${ }^{\circ}$ 122/2007-E, do Juiz Auxiliar da Corregedoria Álvaro Luiz Valery Mirra no Processo CG n. ${ }^{\circ}$ 204/2007, aprovado pelo Corregedor Geral Gilberto Passos de Freitas, em 17.05.07, disponível no site www.extrajudicial.tjsp.jus.br, data de inclusão 22.02.08).
} 
também é possível a averbação da distribuição da execução a partir do início da fase de cumprimento de sentença, por força do artigo 475-R do mesmo código. ${ }^{261}$

Posição interessante quanto a essa questão é defendida por MARCELO JosÉ MAGALHÃEs BoNícIO, para quem a averbação do artigo 615-A pode ser feita logo "no início de uma ação de conhecimento", ${ }^{262}$ pois já a partir desse momento seria possível configurar-se a alienação em fraude de execução. ${ }^{263}$ Embora essa interpretação realmente fosse a mais desejável, tendo em vista a disciplina do artigo 593 do CPC, ela encontra óbice na própria redação do artigo 615-A, ao prever a possibilidade do ajuizamento "da execução", o que já pressupõe o exercício de atividade executiva. ${ }^{264}$

Mesmo não tendo o alcance defendido por BoNício, o artigo 615-A já tem a inequívoca virtude de ampliar a possibilidade de utilização dos registros públicos não só de imóveis, como também de bens móveis - para dar maior publicidade à pendência de ações em fase de execução, antes mesmo que a penhora seja possível, permitindo que terceiros tenham conhecimento desse fato quando da aquisição dos bens.

Assim, em relação à relevância do elemento subjetivo para a configuração da fraude de execução, tem a averbação do artigo 615-A o efeito semelhante ao $\S 4^{\circ}$ do artigo 659 do CPC - de fazer presumir, de forma absoluta, a ciência

\footnotetext{
${ }^{261}$ Nesse sentido, Cássio Scarpinella Bueno sustenta ser o momento do requerimento do cumprimento de sentença na forma do artigo 475-J do CPC o marco inicial para que o exequente requeira a certidão para averbação no registro público (cf. BUENO, Cassio Scarpinella. A nova etapa da reforma do Código de Processo Civil, cit., p. 55) e, entre outros, Eduardo Albuquerque Parente (A eficácia cautelar na averbação da demanda executiva. In: CIANCI, Mirna; QUARTIERI, Rita; MOURÃO, Luiz Eduardo; GIANNICO, Ana Paula C. (Coord.). Temas atuais das tutelas diferenciadas: estudos em homenagem ao prof. Donaldo Armelin. São Paulo: Ed. Revista dos Tribunais, 2009. p. 167).

${ }^{262}$ BONíCIO, Marcelo José Magalhães. A averbação e a fraude de execução na reforma do CPC: artigo 615A. Revista Magister de Direito Civil e Processual Civil, Porto Alegre, n. 20, p. 68, set./out. 2007.

${ }^{263}$ É o que explica o mesmo autor em seus Apontamentos sobre a aparente necessidade de averbação para a configuração da fraude de execução segundo as novas regras do artigo 615-A do CPC. In: CARVALHO, Milton Paulo de. Direito Processual Civil. São Paulo: Quartier Latin, 2007. p. 369 e 373.

${ }^{264}{ }_{E}$ o que defendemos ao examinar o tema em trabalho anterior (cf. AMADEO, Rodolfo da Costa Manso Real. Reflexões sobre a averbação do ajuizamento da execução: artigo 615-A da Lei n. ${ }^{\circ} 11.382$, de 6 de dezembro de 2006. In: COSTA, Susana Henriques da (Coord.). Execução extrajudicial: modificações da Lei n. ${ }^{\circ} 11.382 / 2006$. São Paulo: Quartier Latin, 2007. p. 161). Revisitando o tema da averbação do artigo 615-A, agora à luz da análise histórica empreendida nesta tese, parece-nos que, ao menos em relação aos bens imóveis, há verdadeira sobreposição entre esse instituto e o da hipoteca judiciária (art. 466, CPC), pois em comum, ambos têm seu objetivo principal, qual seja, possibilitar, por meio do cartório de registro de imóveis, que terceiros saibam que aquele bem responde por determinada obrigação objeto de ação pendente e que poderá continuar respondendo mesmo que transferido a seu patrimônio. De diferente, têm o fato de a hipoteca poder ser registrada mesmo antes do início da atividade executiva (cf. art. 466, parágrafo único, I e III, CPC) e sujeita-se a registro, não averbação (cf. art. 167, I, 2, Lei n. ${ }^{\circ}$ 6.015/1973). Em sentido semelhante, cf. CAMPOS, Gledson Marques de; DESTEFANI, Marcos. O novo art. 615-A e a fraude de execução, cit., p. 62.
} 
do terceiro quanto à pendência da ação (cf. § $3^{\circ}$ do art. 615-A, CPC), não alterando o entendimento dominante que, ante a ausência da notícia da ação no registro público, exige a prova do conhecimento do terceiro para a configuração da fraude de execução.

Encerrando a análise desse quarto e último período da história da fraude de execução, podemos concluir que o entendimento atualmente dominante foi se consolidando somente nesse período que decorre (i) da desconsideração de importantes alterações na legislação registrária e no sistema do CPC de 1973 em relação ao do código revogado; e (ii) da generalização da interpretação feita por AMÍLCAR DE CASTRO, já à luz do código revogado, e da maior relevância que lhe foi atribuída em razão das repetidas reformas no artigo $659, \S 4^{\circ}$ do CPC.

Assim, a despeito de o código de 1973, diferentemente do diploma anterior, passar a considerar iniciado o processo desde o despacho inicial ou a distribuição da petição inicial (cf. arts. 262 e 263, CPC), o entendimento dominante exige a citação do devedor ou outra prova de sua ciência quanto à pendência da ação, seja ela fundada em direito real (art. 593, I, CPC), seja de conteúdo condenatório (art. 593, II, CPC).

De forma semelhante, a despeito de a Lei n. ${ }^{\circ}$ 6.015/1973 não mais reproduzir a norma antes existente no artigo 281 do Decreto n. ${ }^{\circ} 4.857 / 1939$ que, para efeitos de fraude de execução, condicionava a litigiosidade da coisa ao registro, no cartório imobiliário, da citação na ação fundada em direito real, o entendimento dominante exige tal registro ou prova da ciência do terceiro quanto à pendência dessa ação real.

Por fim, valendo-se da interpretação conjunta do artigo 593 do CPC com o artigo 240 da Lei n. ${ }^{\circ} 6.015 / 1973$ e, posteriormente, com os artigos 659, $\S 4^{\circ}$, e 615-A, introduzidos no CPC pelas reformas de 1994, 2002 e 2006, o entendimento dominante exige a averbação da penhora - no caso do art. 615-A, da distribuição da execução - ou a prova da ciência do terceiro de que a ação estava pendente. É de se notar, ainda, que tal exigência se faz indistintamente, trate-se do caso de alienação de bem penhorado ou não.

Nesse último período, portanto, a feição do elemento subjetivo alterou-se sensivelmente, passando a ser a má-fé tanto do devedor quanto do terceiro, decorrente da ciência de ambos quanto à pendência da ação. Da mesma forma, sua relevância passou a ser total, de modo que sem sua prova a fraude de execução não está configurada. 


\section{5- Conclusões extraídas da análise histórica}

Da incursão pela evolução histórica da fraude de execução, algumas conclusões importantes podem ser extraídas para a comprovação da hipótese aqui proposta.

A primeira conclusão consiste na verificação de que, originalmente, o elemento subjetivo previsto pela lei como relevante para a configuração da fraude de execução era a má-fé do terceiro, decorrente da existência de razão para que esse soubesse da ação pendente e de sua possível consequência para o patrimônio do devedor. Tal feição original do elemento subjetivo permaneceu inalterada nos dispositivos que regulavam a matéria desde o Regulamento 737/1850 até o Código de Processo Civil de 1939, que acabou por excluir do tipo legal qualquer menção ao elemento subjetivo.

Não obstante tal alteração legislativa, a jurisprudência, inclusive do Supremo Tribunal Federal, continuou exigindo a presença do elemento subjetivo, com base em interpretação analógica do artigo 107 do Código Civil de 1916, que previa elemento subjetivo similar para a hipótese de alienação onerosa em fraude contra credores. A mudança de feição do elemento subjetivo para a má-fé do devedor e do terceiro, decorrente de sua efetiva ciência da ação pendente, somente vai se consolidando já na vigência do atual CPC, em razão de interpretação conjunta com a legislação registrária.

A segunda conclusão alcançada diz respeito ao estabelecimento, também pelo Regulamento 737, de sua relevância apenas para a configuração de uma hipótese específica de fraude de execução, qual seja, a pendência de ação que pudesse reduzir o devedor à insolvência ( $\$ 3^{\circ}$ do art. $494^{\circ}$ ), correspondente à prevista no inciso II do artigo 593 do CPC atual. Em outras duas hipóteses de fraude de execução previstas originalmente pela legislação, quais sejam, pendência de ação real ou reipersecutória sobre o bem alienado (alienação de bem litigioso) e existência de penhora já realizada ou iminente sobre o bem alienado (alienação de bem penhorado), o elemento subjetivo era irrelevante para a sua configuração.

A alteração promovida pelo código de 1939 alterou esse modelo, excluindo essa segunda hipótese de fraude de execução e deixando de prever qualquer menção ao elemento subjetivo no tipo legal, o que foi repetido pelo CPC atual. 
A terceira conclusão refere-se à utilização dos registros públicos nessas hipóteses de fraude de execução. No sistema original da fraude de execução, tendo em vista que as hipóteses de alienação de bem litigioso e de bem penhorado não atribuíam nenhuma relevância ao elemento subjetivo, podendo ocorrer casos em que terceiro poderia perder o bem adquirido mesmo sem ter como saber que esse era litigioso ou estava penhorado, o legislador passou a condicionar a configuração de tais hipóteses à prévia inscrição da penhora ou da citação da ação real ou reipersecutória no registro imobiliário. No entanto, como o código de 1939 estabeleceu disciplina divorciada dessas regras, deu ensejo a interpretação diversa, qual seja a da facultatividade dessas inscrições, servindo as mesmas apenas para criar presunção da ciência do terceiro, de modo que sua ausência deveria ser suprida pela prova de tal fato, a cargo do credor. Dava-se início, assim, ao entendimento atualmente dominante.

Por fim, a quarta conclusão que extraímos da análise histórica aqui realizada é que, tradicionalmente, três eram os meios pelos quais os terceiros poderiam saber da pendência de uma ação que poderia ameaçar sua aquisição: (i) consulta ao cartório público em que o bem está registrado, possível a partir de 1864 (hipoteca judicial) e naturalmente limitada em relação a alguns bens (imóveis, veículos, participações societárias) e a alguns atos processuais (citação em ação real, penhora, hipoteca judicial, ajuizamento da execução); (ii) busca nos distribuidores forenses, já possível desde o início do instituto, mas muito falho em razão de falta de organização e da possibilidade de a ação estar pendente em comarca distinta da do domicílio do devedor ou do local do bem, passou por melhorias na década de 1930; (iii) diretamente do devedor ou de terceiros, sendo aqui de especial interesse as presunções clássicas de fraude, como a alienação ter se dado entre parentes ou amigos, ou por preço vil, ou com a permanência do devedor na posse do bem.

Verifica-se, portanto, que, em nossa hipótese, propomos resgate quase que completo da feição e da relevância do elemento subjetivo tal como se apresentavam antes da entrada em vigor do Código de Processo Civil de 1939. 


\section{5- CONFRONTO ENTRE O ENTENDIMENTO DOMINANTE E A HIPÓTESE PROPOSTA À LUZ DA LEGISLAÇÃO ATUAL}

Com base na análise histórica feita no capítulo anterior, verifica-se que relacionam-se com a matéria objeto desta tese os artigos 219, 263, 466, 592, V, 593, 615A, 659, $\S 4^{\circ}$, do CPC, 167, I, 5 e 21, 169 e 240 da LRP, e $1^{\text {o }}$ da Lei n..$^{\circ}$ 7.433/1985, devendo ainda ser considerada na análise a revogação dos artigos 281 do Decreto n. ${ }^{\circ}$ 4.857/1939 e 824 do CC de 1916, uma vez que não foram repetidos na legislação atual.

É, portanto, à luz dessas normas que iremos confrontar o entendimento dominante e a hipótese proposta nesta tese, lembrando que, para o primeiro, o elemento subjetivo é requisito necessário para a configuração da fraude de execução para as hipóteses dos incisos I e II do artigo 593 do CPC. Além disso, que tal elemento constitui-se da má-fé tanto do devedor quanto do terceiro, decorrente da ciência de ambos quanto à pendência da ação, e que, do lado do devedor essa ciência ocorre, em regra, por meio de sua citação e, do lado do terceiro, presume-se da averbação de algum ato que dê notícia da pendência da ação em registro público, admitindo-se, caso não ocorrida uma ou outra, a prova da ciência do devedor ou do terceiro, cujo ônus cabe exclusivamente ao credor.

Já para a hipótese aqui proposta, o elemento subjetivo somente é relevante para a configuração da fraude de execução nos casos do inciso II do artigo 593 do CPC em que a notícia da pendência da ação não conste de registro público, constituindo-se apenas da má-fé do terceiro, sendo essa decorrente não da efetiva ciência da pendência da ação, mas sim da mera existência de razão para que esse soubesse da pendência da ação, devendo o ônus da prova seguir a regra geral do artigo 333 do CPC.

\section{1- Irrelevância do elemento subjetivo nos casos do inciso I do artigo 593 do Código de Processo Civil e naqueles do inciso II em que a notícia da pendência da ação conste de registro público}

A hipótese de fraude de execução prevista no inciso I do artigo 593 do CPC consiste na pendência de ação fundada em direito real. Vimos no item 2.1, supra, que a exigência do elemento subjetivo pelo entendimento dominante, nesse caso, deriva da 
aplicação do artigo 167, I, 21, da Lei n. ${ }^{\circ}$ 6.015/1973, que prevê a citação em ação (fundada em direito) real como um dos atos sujeitos a registro, cumulado com o artigo 169 dessa mesma lei, que estabelece que todos os atos do artigo 167 seriam obrigatórios. Não estando registrada a citação, o autor da ação teria de demonstrar a ciência do terceiro quanto à sua pendência. Já pressuposta aqui a ciência do réu, posto que o registro exigido é da citação.

Ocorre, contudo, que, à luz da legislação atual, o elemento subjetivo é absolutamente irrelevante para a configuração dessa hipótese de fraude de execução. Em primeiro lugar, porque a norma em que essa interpretação se fundamentava foi revogada.

Vimos no item 4.3, supra, que a exigência de demonstração da má-fé do terceiro nesse caso decorria da conjugação do artigo 895, I, do CPC de 1939, que previa essa mesma hipótese de fraude de execução, e do artigo 281 do Decreto n. ${ }^{\circ}$ 4.857/1939, que estabelecia a necessidade do registro da citação nas ações reais, para que os bens fossem considerados litigiosos para efeito de fraude de execução.

No entanto, vimos no item 4.4, supra, que esse artigo 281 não está mais em vigor, tendo sido revogado pela Lei n. ${ }^{\circ}$ 6.015/1973, que não repetiu a exigência de registro para a configuração da litigiosidade do bem para efeito de fraude de execução.

Além disso, o argumento de que a simples previsão da "obrigatoriedade" desse registro, prevista nos artigos 167, I, 21, e 169 da Lei n. ${ }^{\circ} 6.015 / 1973$, seria suficiente para suprir sua ausência do referido artigo 281 também não convence. Durante toda a discussão sobre os efeitos do registro da penhora, ficou claro que tal "obrigatoriedade" prevista nesse artigo 169 deve ser entendida como ônus e o efeito do registro é simplesmente tornar público o ato para elidir eventual alegação de boa-fé de terceiros.

Nesse caso, portanto, não tendo a Lei n. ${ }^{\circ}$ 6.015/1973 atribuído ao registro das citações em ações reais o efeito de condicionar a configuração da litigiosidade do bem para efeito de fraude de execução - como havia feito o Decreto n. ${ }^{\circ}$ 4.857/1939 no revogado artigo 281 -, já não há mais base legal para exigi-lo como requisito para essa hipótese de fraude de execução. 
Também a própria redação do inciso I do artigo 593 do CPC corrobora a irrelevância do elemento subjetivo para essa hipótese de fraude de execução. Além de não fazer qualquer menção a tal elemento - como os demais dispositivos que regularam essa hipótese desde o $\S 1^{\circ}$ do artigo $494^{\circ}$ do Regulamento 737/1850 -, a norma de 1973 limitou essa hipótese à pendência de ação fundada em direito real.

Em sendo real o direito em que se funda a ação, já tem ele, como uma de suas características principais, a sequela, que permite a seu titular alcançar o bem em poder de qualquer terceiro, ainda que de boa-fé, em razão de sua oponibilidade erga omnes. ${ }^{265}$ Sendo comumente afirmado que essa hipótese de fraude de execução destina-se a tutelar $o$ direito de sequela, ${ }^{266}$ é de se estranhar a exigência de má-fé pelo entendimento dominante.

Diante desse fato, seria lícito perguntar, então, que utilidade teria o registro em elidir a boa-fé do terceiro se mesmo sem ele seria possível alcançar o bem. As respostas a essas perguntas devem ser buscadas no direito material, pois embora irrelevante para a configuração da fraude de execução, a boa ou má-fé do terceiro possui grande

\footnotetext{
${ }^{265}$ Nesse sentido, cf. Washington de Barros Monteiro, que enuncia entre as características fundamentais dos direito reais, as de que ele " a) adere imediatamente à coisa, sujeitando-a diretamente ao titular; b) segue seu objeto, onde quer que este se encontre. É o direito de seqüela, que constitui o apanágio do direito real; c) é exclusivo, nesse sentido de que não é possível instalar-se direito real onde outro já exista; d) é provido de ação real, que prevalece contra qualquer detentor da coisa, razão pela qual preferem muitos denominá-lo absoluto (...)" (MONTEIRO, Washington de Barros. Curso de direito civil: direito das coisas. 17. ed. São Paulo: Saraiva, 2003. p. 14). Também Orlando Gomes: "as características dos direitos reais são a seqüela e a preferência. Já se disse, com razão, que constituem as suas superioridades sobre os direitos de crédito. (...) O direito de sequiela é o que tem o titular de direito real de seguir a coisa em poder de todo e qualquer detentor ou possuidor. Para significá-lo, em toda a sua intensidade, diz-se que o direito real adere à coisa como a lepra ao corpo (uti lepra cuti). Não importam usurpações; acompanhará sempre a coisa. Se grava determinado bem, como no caso de servidão, nenhuma transmissão o afetará, pois, seja qual for o proprietário do prédio serviente terá de suportar o encargo. Enfim, a inerência do direito ao seu objeto é tão substancial que o sujeito pode persegui-lo seja qual for a pessoa que o detenha. O direito de preferência é restrito aos direitos reais de garantia. (RA) O direito de preferência é referido no artigo 1.419 da lei n. ${ }^{\circ}$ 10.406/02, com redação mantida a partir do artigo 755 do CC de 1916. (RA) Consiste no privilégio de obter o pagamento de uma dívida com o valor de bem aplicado exclusivamente à sua satisfação. Constituído o direito real de garantia, a responsabilidade da obrigação se concentra sobre determinado bem do patrimônio do devedor. Para o caso de inadimplemento tem o credor o direito de se satisfazer sobre o valor desse bem, afastando credores que tenham apenas direito pessoal contra o devedor ou mesmo direito real de inscrição posterior. Em suma, a coisa dada em garantia é subtraída à execução coletiva. O credor pignoratício, ou hipotecário, prefere a todos os outros, o que é de evidente vantagem, pois plus cautionis est in re, quam in persona" (GOMES, Orlando. Direitos reais. 19. ed. rev. e atual. por Luiz Edson Fachin. Rio de Janeiro: Forense, 2008. p. 19-20).

Ainda nesse sentido - e especificamente em relação ao tema - a lição de Philadelpho Azevedo ao confrontar as normas do Código Civil de 1916 com o $\$ 1^{\circ}$ do art. $494^{\circ}$ do Reg. 737, que previa esse caso: "como corollario do systema real e não da presumpção absoluta de fraude, pelo facto de correr uma acção em juizo, se deve considerar em vigor o disposto no art. $494 \S 1^{\circ}$ do Regulamento 737, apezar dos prejuizos que podem advir a terceiros de bôa-fé; mesmo os possuidores mediatos não estão a salvo de reivindicação." (AZEVEDO, José Philadelpho de Barros e. Da fraude contra sentenças, cit., p. 28).
} 
relevância para outros fins, como a indenização em caso de evicção ou o prazo de aquisição da propriedade mediante usucapião (arts. 457, 1.238 e ss. e 1.260 e ss. do CC).

Muito não será preciso dizer no tocante à irrelevância do elemento subjetivo nos casos do inciso II do artigo 593 do CPC em que a notícia da pendência da ação conste de registro público; ela decorre das disposições do o $659, \S 4^{\circ}$, e 615 , § $3^{\circ}$, CPC, que instituem "presunção absoluta de conhecimento por terceiros".

Pode parecer despicienda a menção a esses casos, no presente capítulo, já que neles o entendimento dominante também não exige do credor a prova do elemento subjetivo, não existindo "confronto" algum a ser feito. Não é verdade.

A diferença de posicionamentos que se quer remarcar aqui é a do ângulo pelo qual essa questão é vista, o que interfere na interpretação da natureza que se atribui a essa presunção e, conseqüentemente, na questão da distribuição do ônus da prova, que será tratada no item 5.4, infra.

O entendimento dominante aborda essa questão do ponto de vista da prova: havendo a averbação da penhora ou do ajuizamento da execução no registro público, dispensa-se a prova do elemento subjetivo; não havendo, exige-se tal prova, com ônus para o credor. Ao ver a questão sob esse ângulo, interpreta-se a presunção prevista nos arts. $659, \S 4^{\circ}$, e $615-\mathrm{A}, \S 3^{\circ}$, do CPC como se se tratasse de presunção relativa, pois são presunções dessa natureza que acarretam tal efeito processual.

Ao contrário, nossa hipótese aborda a questão do ponto de vista dos requisitos necessários para a configuração da fraude de execução, sustentando que o elemento subjetivo é irrelevante para a configuração da fraude de execução nesse caso: não importa se o terceiro efetivamente tinha conhecimento da pendência da ação ou se, por alguma circunstância, sequer poderia saber dela; estando averbada a penhora ou a distribuição da execução no registro público, qualquer discussão a respeito desse fato é inadmissível. Vista a questão sob esse ângulo, a interpretação trata a presunção como absoluta, aproximando-se do texto, que lhe atribui expressamente essa natureza.

${ }^{266}$ Por todos, cf. THEODORO JÚNIOR, Humberto. Processo de execução, cit., p. 195. 
Mais uma vez oportunas aqui as lições de BARBOSA MOREIRA sobre as diferenças entre as presunções legais relativas e absolutas: "do exposto ressalta com meridiana clareza a função prática exercida pela presunção legal relativa: ela atua - e nisso se exaure o papel que desempenha - na distribuição do ônus da prova, dispensando deste o litigante a quem interessa a admissão do fato presumido (...) As presunções legais absolutas nada têm que ver com a prova (...) os fatos legalmente presumidos iuris et de iure, na verdade, não são apenas fatos que dispensem prova; são fatos irrelevantes já do ponto de vista material, isto é, fatos que não precisam ocorrer para que se produza o efeito previsto em lei." 267

Assim, já nesse primeiro ponto, relativo ao âmbito da relevância do elemento subjetivo para a configuração da fraude de execução, a hipótese aqui proposta mostra-se mais adequada às disposições legais referentes à matéria.

\section{2- Irrelevância do elemento subjetivo do devedor}

$\mathrm{O}$ segundo ponto de confronto entre o entendimento dominante e a hipótese aqui proposta diz respeito à relevância ou irrelevância da má-fé do devedor para a configuração da fraude de execução.

Em relação a ele, já analisamos no item 3.1, supra, que o entendimento dominante sustenta a necessidade ciência do devedor fundamentando-se em dois argumentos distintos, quais sejam, (i) o processo somente estaria pendente quando de sua citação; e, (ii) ainda que se considerasse pendente o processo antes da citação, somente seria razoável supor a fraude do devedor se esse já tivesse conhecimento da ação.

A nosso ver ambos os argumentos encontram-se suficientemente refutados pela doutrina processual com base na interpretação da legislação vigente.

Quanto ao primeiro argumento, a análise histórica feita no item 4.4, supra, evidenciou que, ao contrário do sistema do código de 1939, o CPC atual estabelece em seus artigos 262 e 263 que "o processo civil começa por iniciativa da parte", 
considerando-se "proposta a demanda, tanto que a petição inicial seja despachada pelo juiz, ou simplesmente distribuída onde houver mais de uma vara."

Até mesmo a truncada redação do artigo 219 corrobora essa interpretação. Portanto, tendo sido proposta a ação - o que ocorre no mais das vezes com a distribuição da petição inicial no cartório distribuidor -, a fraude de execução já pode ser configurada.

Sobre a ausência de base legal para esse primeiro argumento, MARIA BERENICE DiAs sustenta que "fixando a lei processual, em seu art. 263, o momento em que se instaura a relação jurídica processual: 'considera-se proposta a ação tanto que a petição inicial seja despachada pelo Juiz, ou simplesmente distribuída, onde houver mais de uma Vara', e estabelecendo o seu art. 593 como pressuposto para comprovar a fraude de execução, a existência de demanda, não se pode afastar tal marco para momento posterior, sem que isso disponha de falta de absoluto respaldo legal." 268

Apesar de ser ainda minoritário, o entendimento que dispensa a citação do devedor para se considerar pendente a ação tem persistido e, ao longo dos últimos anos, tem ganhado força no âmbito doutrinário, angariando cada vez mais novos defensores. ${ }^{269}$

primeira série. 2. ed. São Paulo: Saraiva, 1988. p. 60 e 67, respectivamente.

${ }^{268}$ DIAS, Maria Berenice. Fraude à execução (algumas questões controvertidas). Ajuris: revista da Associação dos Juízes do Rio Grande do Sul, Porto Alegre, v. 17, n. 50, p. 75-76, nov. 1990.

${ }^{269}$ Cf. Haroldo Cabral Figueiredo (Fraude de execução. Jurisprudência Brasileira, n. 104, p. 13-15, 1985); José Sebastião de Oliveira (Fraude à execução, cit., p. 76); Pedro dos Santos Barcelos (Fraude de execução. Revista dos Tribunais, São Paulo, v. 79, n. 658, p. 45, ago. 1990); Ronaldo Brêtas de Carvalho Dias, (Fraude no processo civil. 2. ed. Belo Horizonte: Del Rey, 2000. p. 16); Eduardo Henrique de Oliveira Yoshikawa (Do caráter objetivo da fraude à execução e suas consequências (artigo 593, II, do CPC), cit., p. 45; CAIS, Frederico Fontoura da Silva. Fraude de execução, cit., p. 135); e Luiz Fux, afirmando claramente esse último que "à luz do texto, é fraudulenta a alienação depois da propositura da ação e antes da citação, uma vez que a exigência da lei para considerar ineficaz o ato é de que, ao tempo da alienação, corra contra o devedor demanda capaz de reduzi-lo à insolvência. Ora, considera-se demandado o devedor, desde que distribuída a ação onde houver mais de um juízo com competência concorrente ou despachada, onde houver um só juízo (art. 263 do CPC)." (FUX, Luiz. O novo processo de execução: o cumprimento da sentença e a execução extrajudicial, cit., p. 99).

$\mathrm{Na}$ jurisprudência, contudo, tal posicionamento não tem demonstrado expansão. Ao contrário, atualmente, está praticamente consolidado no sentido de exigir a citação ou a prova, a cargo do credor, da ciência do devedor: "a alienação ou oneração de bens, antes da citação válida, não configura fraude de execução." (STJ, 4 ${ }^{\mathrm{a}}$ T., AgRg no REsp 316.905/SP, rel. Min. Luis Felipe Salomão, j. 20.11.08); "consoante entendimento das duas Turmas que compõem a $2^{a}$ Seção, não se configura fraude à execução se a venda do veículo pertencente à executada ocorreu antes da citação da devedora e da penhora do bem." (STJ, $4^{\mathrm{a}} \mathrm{T}$., REsp 694.728/RS, rel. Min. Jorge Scartezzini, j. 07.11.06). 
Além disso, tal interpretação foi reforçada pelas reformas processuais, uma vez que o legislador criou diversos mecanismos referentes à prática de atos processuais antes da citação do réu ou do devedor. O próprio artigo 615-A é exemplo disso, uma vez que permite a configuração da fraude de execução antes da citação do devedor. Outros dois exemplos são os artigos 253, II, alterado pela Lei n. ${ }^{\circ} 11.280 / 2006$ e o artigo 285-A, incluído pela Lei n. ${ }^{\circ}$ 11.277/2006.

Também os autores que sustentam o segundo argumento acabam, necessariamente, por refutar esse primeiro. Sobre o assunto, ensina DINAMARCO que “conceitualmente, processo pendente é o que já se iniciou e ainda não se extinguiu. Esse é o conceito elementar de litispendência."270

Já quanto ao segundo argumento, além de, historicamente, o direito positivo brasileiro não exigir a má-fé do devedor para a configuração dos casos de fraude de execução - e mesmo de fraude contra credores, como vimos -, nota-se que o artigo 659, $\S 4^{\circ}$, do CPC, ao excluir do tipo legal o elemento subjetivo, presumindo-o absolutamente, o faz apenas em relação ao terceiro e não em relação ao devedor, o que demonstra que sua má-fé sequer seria exigida, de início.

Interpretação contrária implicaria admitir que, em caso de fraude de execução decorrente de alienação de bem após a averbação da penhora em registro público, se o devedor demonstrasse não ter tido ciência da pendência da ação, a aquisição do bem pelo terceiro não seria mais considerada em fraude de execução, ficando o bem a salvo da atividade executiva.

A completa falta de sentido lógico nesse caso evidencia que a má-fé do devedor é de todo irrelevante para a configuração da fraude de execução. ${ }^{271}$

\footnotetext{
${ }^{270}$ DINAMARCO, Cândido Rangel. As fraudes do devedor, cit., p. 442, destaques no original.

${ }^{271} \mathrm{Em}$ apoio a esse ponto, cf. em termos semelhantes a Sérgio Coelho Junior: "a citação do réu é, de outro lado, absolutamente irrelevante para as consequências advindas para o terceiro, pois não pode servir de índício para a presunção de que este sabia da existência da ação. É no subjetivismo do adquirente que se deve buscar o fundamento da ineficácia do ato fraudulento." (COELHO JUNIOR, Sérgio. Fraude de execução e garantias fundamentais do processo, cit., p. 156).
} 
Por fim, outro importante argumento em favor da irrelevância do elemento subjetivo do devedor será explorado no capítulo 6, infra, em que se procurará demonstrar que o efeito da decretação da fraude de execução opera-se somente em relação ao terceiro.

Contrariamente à nossa hipótese, poder-se-ia levantar o argumento de que, em duas oportunidades relacionadas com a fraude de execução, o legislador considera relevante o elemento subjetivo do devedor. Trata-se dos artigos 600, I, c/c 601 do CPC, em que a fraude de execução é considerada como ato atentatório à dignidade da justiça, e 179 do Código Penal, que tipifica o crime de fraude à execução, nos seguintes termos:

"Art. 179 - Fraudar execução, alienando, desviando, destruindo ou danificando bens, ou simulando dívidas:

Pena - detenção, de 6 (seis) meses a 2 (dois) anos, ou multa.

Parágrafo único - Somente se procede mediante queixa."

No entanto, nota-se que, em nenhum dos casos, o efeito desencadeado pelo reconhecimento do elemento subjetivo do devedor é a possibilidade de o bem ser alcançado pelos atos executivos em patrimônio de terceiro. Ao contrário, os efeitos atribuídos por esses dispositivos à conduta de má-fé do devedor cingem-se à aplicação de penas - multa de até $20 \%$ do valor da execução, pelos artigos 600, I, e 601, CPC e detenção de seis meses a um ano, pelo artigo 179 do $\mathrm{CP}$ - ao devedor que praticar tais condutas.

É interessante observar, ainda, que as condutas descritas como crime de fraude à execução (art. 179, CP) não coincidem totalmente com os atos que podem ser praticados em fraude de execução (arts. 592, V, e 593, CPC), sendo aquelas mais amplas que esses. Assim, para o Código de Processo Civil os atos que podem ser praticados em fraude de execução são apenas a alienação ou a oneração de bens; já para o Código Penal, também configurariam crime de fraude à execução as condutas de desvio, destruição ou danificação de bens. ${ }^{272}$ Além disso, também prevalece entre os penalistas o entendimento

\footnotetext{
${ }^{272}$ Cf. Damásio E. de Jesus: “conduta típica: consiste em fraudar execução de sentença condenatória, evitando a penhora por intermédio da alienação de bens, desvio, destruição ou sua danificação, ou por simulação de dívidas. Pressuposto Típico é a existência de uma sentença a ser executada ou uma ação executiva." (JESUS, Damásio de. Código Penal anotado. 18. ed. atual. São Paulo: Saraiva, 2007. p. 688).
} 
de que tais condutas somente configurariam crime se praticadas no âmbito da execução e não na fase de conhecimento do processo. ${ }^{273}$

Também em relação ao artigo 600, I, CPC, prevalece o entendimento de que a conduta nele prevista também não seria coincidente com os atos previstos nos artigos 592, V e 593 do $\mathrm{CPC}^{274}$

Verifica-se, portanto, que esses dispositivos não tratam exatamente das hipóteses de fraude de execução previstas nos artigos 592, V e 593 do CPC e, menos ainda, estabelecem que o elemento subjetivo do devedor seria requisito para a sua configuração, de forma que não são capazes de infirmar a hipótese aqui defendida.

\section{3- Investigação do elemento subjetivo em sua feição original}

Demonstrado nos itens anteriores que somente o elemento subjetivo do terceiro - e não o do devedor - é relevante para a configuração da fraude de execução e que essa relevância somente se verifica nos casos do inciso II do artigo 593 do CPC em que a notícia da pendência da ação não conste de registro público, outro ponto em que devem ser confrontados o entendimento dominante e a hipótese aqui proposta diz respeito à feição que se atribui a esse elemento subjetivo do terceiro.

\footnotetext{
${ }^{273}$ Cf., nesse sentido, Paulo José da Costa Jr.: "pressuposto do crime é a existência de uma sentença a ser executada, ou de uma execução. Basta o ajuizamento da ação, não se fazendo mister que haja uma penhora efetiva. Em razão do início da execução, que o agente visa a fraudar, são praticados os atos enumerados pela lei: alienar, desviar, destruir, danificar bens ou simular dívidas." (COSTA JR., Paulo José. Comentários ao Código Penal: parte especial. 2. ed. São Paulo: Saraiva, 1989. v. 2, p. 434) e, também, Julio Fabbrini Mirabete, embora indique a existência de entendimento contrário: "pressuposto indeclinável da existência da fraude à execução é uma ação civil em fase de execução ou de uma ação executiva. Refere-se Noronha à 'execução aparelhada' e Bento de Faria à desnecessidade da execução ajuizada ou á iminência da execução, mas o tipo penal só existe quando houver fraude à execução. Já se tem decidido, porém, que basta haver uma lide civil com a citação do devedor para o processo, quer de conhecimento, quer de execução (RT 520/478)." (MIRABETE, Julio Fabbrini. Manual de direito penal: parte especial. 20. ed. São Paulo: Atlas, 2003. v. 2, p. 351).

${ }^{274}$ Cf., por todos, Dinamarco, que, invocando lições de Amílcar de Castro e Alcides de Mendonça Lima, afirma: "quanto à conduta consistente em fraudar a execução (art. 600, inc. I), não é pacífico em doutrina se se trata do próprio instituto da fraude de execução, disciplinado no art. 593 do Código de Processo Civil, ou se, mais amplamente, ali está previsto 'outro qualquer expediente capaz de frustar a execução, como, por exemplo, a ocultação de bens móveis, sem aliená-los'. A segunda solução parece mais perto da verdade, porque a fraude de execução (art. 593) não impede o curso das medidas executivas, nem exclui da responsabilidade patrimonial o bem alienado ou gravado (art. 592, inc. V); e o que se visa a reprimir, mediante a sanção ao contempt, são as medidas que conduzam àqueles resultados." (DINAMARCO, Cândido Rangel. Execução civil, cit., p. 188).
} 
Em relação a esse ponto, tanto o entendimento dominante, quanto nossa hipótese utilizam o termo má-fé para designar esse elemento subjetivo do terceiro, em oposição à boa-fé, que excluiria essa hipótese de fraude de execução.

No entanto, os sentidos atribuídos a má-fé são diversos. Para o entendimento dominante, a má-fé do terceiro corresponderia à sua ciência da ação pendente. ${ }^{275}$ Já nossa hipótese, resgatando a feição original do elemento subjetivo na fraude de execução, como visto no capítulo 4, infra, sustenta que tal má-fé decorreria da existência de razão para que esse terceiro soubesse da pendência da ação. ${ }^{276}$

Esse talvez seja o ponto mais difícil de se valer da legislação atual para contrapor os dois entendimentos, dado que, desde 1939, não há nenhum dispositivo específico sobre o assunto. A única norma que permite vislumbrá-lo - e, ainda assim, de forma oblíqua - é a do $\S 4^{\circ}$ do artigo 659 do CPC, que após a redação que lhe foi dada pelas Leis n. ${ }^{\text {os }} 10.444 / 2002$ e 11.382/2006, passou a dispor que a averbação da penhora no registro público gera "presunção absoluta de conhecimento por terceiros".

Lido à vista desarmada, tal dispositivo conduziria o intérprete mais ligeiro a concluir pela prevalência da feição dada a esse elemento subjetivo pelo

\footnotetext{
${ }^{275}$ É esse, por exemplo, o sentido usado pela súmula 375 do Superior Tribunal de Justiça, conforme visto no Apêndice 1 e na interpretação de Dinamarco (cf. As fraudes do devedor, cit., p. 446). Há autores que reservam o termo má-fé para a intenção de frustrar a execução, distinguindo-a da ciência. No entanto, acabam por exigir a ciência - e não a intenção - como requisito para a configuração da fraude de execução. Cf., entre outros, Eduardo Talamini e Elmar Tobias Talamini: "a questão da 'má-fé' não se confunde com a ciência, pelos adquirentes, da existência da demanda capaz de reduzir o alienante à insolvência. A má-fé consiste na 'intenção de prejudicar' credores (Amílcar de Castro. Comentários ao CPC. 3. ed. São Paulo: Ed. Revista dos Tribunais, v. 8, p.82). Já quando se trata da 'ciência da demanda', não se perquire da intenção de prejudicar terceiros. Basta que o adquirinte saiba que pende ação capaz de tornar o alienante insolvente. Mas tal 'ciência', essa sim, é imprescindível para a caracterização à fraude à execução. Apenas quando se provar eu o adquirente tinha ciência da existência da ação capaz de tornar o alienante insolvente, é que se caracterizará a fraude de execução (ainda que ele não pretendesse prejudicar terceiros). Em suma, quando se afirma que a má-fé é desnecessária para a caracterização da fraude de execução, quer com isso dizer-se que é dispensável o animo de prejudicar credores. Entretanto, o conhecimento pelo adquirente de demanda é capaz de reduzir o alienante à insolvência é requisito inafastável para ocorrência de fraude de execução" (TALAMINI, Eduardo; TALAMINI, Elmar Tobias. Embargos de terceiro - requisitos para caracterização de fraude à execução. Revista de Processo, São Paulo, n. 89, p. 242, jan./mar. 1998). Assim, para uniformidade da terminologia, esclarece-se que será utilizada a expressão má-fé no sentido de ciência e não de intenção, ainda que haja autores que façam ressalva semelhante à verificada acima.

${ }^{276} \mathrm{Cf}$. $\S 3^{\circ}$ do artigo $494^{\circ}$ do regulamento 737: "quando o possuidor dos bens tinha razão para saber que pendia demanda, e outros bens não tinha o executado por onde pudesse pagar" e artigos correspondentes nos diversos códigos estaduais e regulamentos federais até o advento do Código de Processo Civil de 1939.
} 
entendimento dominante. Presumido o "conhecimento" do terceiro, sua má-fé decorreria, portanto, de sua efetiva ciência da pendência da ação.

No entanto, aqui novamente a análise histórica feita no capítulo anterior fornece outra perspectiva de interpretação. Quando a redação do $\S 4^{\circ}$ do artigo 659 do CPC prevista na Lei n. ${ }^{\circ}$ 10.444/2002 foi idealizada, já prevalecia na jurisprudência do Superior Tribunal de Justiça o entendimento atualmente dominante, que exige a ciência para a caracterização da má-fé do terceiro. E a nova lei, ao ser elaborada, foi moldada conforme tal entendimento, até mesmo porque contou com a ativa participação de ministros daquele tribunal na elaboração de seu anteprojeto.

Tal constatação mostra que a análise à luz dessa norma estaria viciada, pois, ao fim e ao cabo, estar-se-ia analisando o entendimento dominante à luz dele mesmo.

Ainda que o $\S 4^{\circ}$ do art. 659 , do CPC não se afigure como critério válido para pautar o confronto aqui pretendido, dado que foi plasmado no próprio entendimento dominante, um cuidado essencial deve inspirar: sendo norma vigente, é preciso verificar se seus termos não inviabilizam ou excluem a intrepretação dada por nossa hipótese.

A resposta é negativa. Vimos acima que o referido $\S 4^{\circ}$ presume o "conhecimento" do terceiro, caso a penhora esteja averbada. Tal norma não exclui ou inviabiliza nossa hipótese, pois a presunção de conhecimento nela constante não é incompatível com ela. Presumido o conhecimento, que é mais grave e mais amplo, estaria presumida também - e com maior razão - a possibilidade desse conhecimento que, sendo mais branda e mais restrita, nele estaria contida.

Vale dizer, se o legislador presume o "conhecimento por terceiros", abrange tanto aquele conhecimento que possui razão para existir, quanto o que não possui. Havendo ou não razão para o terceiro ter conhecimento da ação pendente, esse é presumido, demonstrando nossa hipótese está contida naquela norma. 
Vemos assim que, embora não exclua o entendimento dominante, o que se explica devido à sua origem, o artigo $659, \S 4^{\circ}$, do CPC também não exclui a hipótese por nós proposta, permitindo que se prossiga no confronto objeto desse capítulo.

Diante da inexistência de dispositivo legal de que se extraia o significado da má-fé do terceiro, far-se-á a análise pela identificação da boa-fé que a ela se contrapõe. Tal análise ganha especial relevo atualmente, na medida em que o próprio legislador, no artigo 422 do Código Civil vigente, positivou a boa-fé, erigindo-a como regra integrativa de conduta, aplicável à generalidade dos negócios jurídicos. ${ }^{277}$

Em artigo específico sobre o tema, CARlos Augusto DE Assis define a boa-fé como "o estado psicológico daquele que pratica um ato crendo, erroneamente, estar diante de situação jurídica diferente da efetivamente existente." $\mathrm{O}$ autor, conclui, no entanto, que esse estado não se verifica no caso de negligência, pois "a boa-fé do adquirente, que merece integral proteção do direito, é a do adquirente cauteloso, ou seja, aquele que se cerca das garantias elementares antes de efetuar a transação."278

A mesma ideia da necessidade de diligência para embasar a crença errônea da qual advém a boa-fé é também encontrada na clássica obra de ALVINO LiMA, para quem "esta crença errônea e excusável não se justifica no caso de dúvida ou negligência; tôda pessoa que se vincula através da prática de um ato jurídico, tem o dever de tomar as precauções necessárias e verificar se o ato a concluir é realmente legal. A dúvida, assim como a negligência viciam a boa-fé, porquanto há uma verdadeira obrigação de examinar, com cuidado leal, se os atos que vamos praticar são ou não contrários ao direito. Consequentemente, tanto vale agir com a vontade ou o propósito deliberado de frustrar a lei, de se subtrair ao seu imperativo mediante subterfúgios, como ter praticado o ato, frustrando a lei, embora sem aquela intenção premeditada, mas sem a diligência

\footnotetext{
${ }^{277}$ Assim dispõe o referido artigo 422: Os contratantes são obrigados a guardar, assim na conclusão do contrato, como na sua execução, os princípios de probidade e boa-fé. Sobre sua aplicação aos casos de fraude de execução, cf. Luciano Mollica: "não há dúvidas de que, na realização dos negócios imobiliários, a boa-fé aplicável é a de cunho objetivo, pois se vincula a um comportamento padrão esperado do adquirente, que visa a demonstrar que o adquirente foi diligente na sua aquisição, especialmente para evitar ferir direitos de terceiros interessados. Até porque na outra ponta estará o interesse do credor, que não poderá ficar à mercê da negligência do terceiro adquirente (...) a boa-fé do adquirente imobiliário se relaciona intimamente aos cuidados por ele adotados quando da aquisição" (MOLLICA, Luciano. Novos contornos para a fraude de execução na alienação de bem imóvel, sob a perspectiva de dinamizar os negócios imobiliários, cit., p. 76).
} 
imprescindível e normal referida; ou ainda, sob a influência de dúvida quanto à legitimidade do ato concluído."279

Sem ingressar na tormentosa questão do conteúdo dessa diligência - que será abordada no item 7.6, infra -, o ponto para o qual se quer chamar a atenção aqui é que ela é considerada parte integrante da boa-fé. Vale dizer, só se considera de boa-fé o terceiro que agiu diligentemente, perquirindo, investigando, buscando saber se existiam motivos que pudessem ameaçar ou infirmar o negócio a ser realizado.

Transposta essa lição para a definição da má-fé, extrai-se, logicamente, a conclusão de que, não agindo com tal diligência, o terceiro estará de má-fé. Ou, noutros termos, havendo razão para que soubesse da pendência da ação e não tendo o terceiro tido a diligência de descobri-la, estará configurada a sua má-fé.

Tal conclusão, baseada no conceito de boa-fé dado pela doutrina clássica e amparado no artigo 422 do CC atual, reforça - também nesse ponto - a hipótese aqui defendida, em detrimento do entendimento dominante que, ao exigir a ciência do terceiro, acaba por limitar demais a verificação da fraude de execução nos casos concretos.

De fato, o corolário lógico da exigência da ciência para a caracterização da má-fe é a conclusão de que basta a ignorância do terceiro quanto à pendência da ação para que seja considerado de boa-fé, afastando a configuração da fraude de execução."280

Levada ao extremo a posição defendida pelo entendimento dominante, bastaria, portanto, que o terceiro se abstivesse de qualquer diligência em pesquisar a existência de ações pendentes envolvendo o devedor, provando que adquiriu o bem na

\footnotetext{
${ }^{278}$ ASSIS, Carlos Augusto de. Fraude à execução e boa-fé do adquirente, cit., p. 225 e 234, respectivamente.

${ }^{279}$ LIMA, Alvino. A fraude no direito civil, cit., p. 51. Ainda sobre o tema, cf. Marcelo Terra, com apoio em lição de Octávio Moreira Guimarães: "a boa-fé se origina de um erro escusável, de um engano relevado; há de ser certamente expressão de um ato sério e ponderado. Só erra escusadamente quem se atém ao fato e o examina e perquire; quem procede com diligência e cuidado. Quem errar por leviandade, por precipitação, ou, em suma, por culpa, erra sem escusa. (...) A caracterização da boa fé do terceiro adquirente resultará de sua atitude diligente (não a excessiva, e sim a do bom pai de família)." (TERRA, Marcelo. A fé pública registral. Revista de Direito Imobiliário, São Paulo, n. 26, p. 47-48, jul./dez. 1990).

${ }^{280}$ Fazendo esse raciocínio, cf., por exemplo, José Carlos Baptista Puoli que, ao comentar o artigo 659, $4^{\circ}$, CPC, sustenta que: "aquisição e/ou oneração (...) praticada de boa-fé" seria aquela realizada "na ignorância
} 
mais absoluta ignorância para que restasse configurada a sua boa-fé. Na realidade, dada a atribuição do ônus da prova ao credor - o que será analisado no próximo item -, o terceiro nem mesmo precisaria incomodar-se em provar sua ignorância, bastando alegá-la.

O absurdo da situação reforça a conclusão, já alcançada acima, de que é a feição original da má-fé do terceiro, decorrente da existência de razão para que ele soubesse da pendência da ação, que deve orientar sua aferição nos casos em que o elemento subjetivo seja relevante para a configuração da fraude de execução. Diríamos, portanto, que não basta haver ignorância, essa deve ser uma "ignorância diligente".

\section{4- Inexistência de regra excepcional de distribuição do ônus da prova}

Finalmente, o quarto ponto em que o entendimento dominante e a hipótese aqui proposta devem ser confrontados à luz da legislação atual é o relativo à distribuição dos ônus da prova da má-fé do terceiro, caso não esteja registrada a penhora ou a distribuição da execução.

Para o entendimento dominante, tal ônus caberia sempre ao credor, uma vez que, não estando averbada a penhora ou a distribuição da execução no registro público, ele não se beneficiaria da presunção existente nos artigos $659, \S 4^{\circ}$, ou $615-\mathrm{A}, \S 3^{\circ}$, do $\mathrm{CPC}$, que o dispensariam dessa prova.

Para nossa hipótese, a distribuição do ônus da prova do elemento subjetivo seguiria a regra geral do artigo 333 do CPC, uma vez que não existiria qualquer dispositivo legal que alteraria essa distribuição.

Em defesa de nossa hipótese, já levantamos, no item 5.1, supra, o fato de as presunções existentes nos artigos 659, $\S 4^{\circ}$, e 615-A, $\S 3^{\circ}$, do CPC serem de natureza absoluta e não relativa, de modo que seu efeito seria o de excluir a relevância do próprio 
elemento subjetivo do tipo legal da fraude de execução e não meramente o de dispensar sua prova, conforme a brilhante lição de BARBOSA MOREIRA, aqui já várias vezes citada. ${ }^{281}$

Sendo assim, e tal fato parece incontestável diante da própria redação do artigo $659, \S 4^{\circ}$, 282 e da interpretação amplamente majoritária que vem recebendo o artigo 615-A, $\S 3^{\text {o }}{ }^{283}$ se a hipótese não for de alienação de bem com penhora ou distribuição da execução averbadas - únicas em que o elemento subjetivo é excluído do tipo legal, por força da presunção absoluta -, volta a valer a regra geral de distribuição dos ônus da prova.

Mesmo que se admitisse como correta a interpretação de que tais presunções seriam relativas, o entendimento dominante ainda é falso nesse ponto. Explicase: ao dizer que, havendo a averbação, o credor estaria dispensado da prova da má-fé em razão da presunção e, não havendo a averbação, teria ele o ônus dessa prova; tal entendimento está admitindo que o ônus dessa prova seria sempre do credor e que a presunção relativa o estaria invertendo quando houvesse averbação.

Ocorre, contudo, que não é verdade que a presunção relativa sempre inverte o ônus da prova e, especialmente no que diz respeito à fraude de execução, tal assertiva é ainda menos verdadeira, como será visto adiante.

Em abono a essa nossa última afirmação, novamente as palavras de BARBOSA MOREIRA: não parece inteiramente exato dizer, todavia, que a presunção legal (relativa) se resolve em inversão do onus probandi. Com efeito, o resultado da aplicação da regra especial (contida no dispositivo que estabelece a presunção) pode perfeitamente coincidir, em determinado caso, com o resultado que se obteria aplicando à espécie a regra geral de distribuição daquele ônus. Isto é: pode acontecer que o ônus houvesse mesmo de recair, em virtude de sua posição processual, sobre a pessoa a quem a presunção legal desaproveita. É claro que a importância da presunção legal avulta precipuamente nos casos de não-coincidência, pois nestes é que ela produz efeitos práticos apreciáveis; mas permanece válida a observação de que as presunções legais não constituem propriamente exceções à regra comum sobre distribuição do ônus da prova: as normas que as consagram

${ }^{281}$ BARBOSA MOREIRA, José Carlos. Presunções e prova, cit., p. 63.

${ }^{282}$ Que prevê expressamente que a averbação gera: "presunção absoluta de conhecimento por terceiros". 
são, isso sim, normas especiais, que prevalecem sobre a regra geral, sem necessariamente contradizê-la in concreto. ${ }^{284}$

Fica claro, portanto, que a presunção relativa decorrente da averbação não implica que nos casos em que ela não incida, o ônus da prova seria sempre do credor. Assim, quer se considerando a presunção absoluta, quer relativa, para fora do campo de sua incidência - isto é, para os casos em que não haja averbação - a consequência é a mesma: vale a regra geral da distribuição do ônus da prova.

No entanto, sendo uma das principais características da fraude de execução a sua declaração no próprio processo pendente entre o credor e o devedor, com a imediata constrição do bem alienado, devendo o terceiro valer-se de ação autônoma de embargos de terceiro (arts. 1.046 e ss., CPC) para demonstrar a inocorrência da fraude de execução, a regra geral do ônus da prova fica ao mesmo tempo duplicada e invertida.

No processo principal, em que está se desenvolvendo a atividade executiva, o credor está no pólo ativo, cabendo a ele provar os fatos constitutivos de seu direito, inclusive do direito de executar bens alienados em fraude de execução. Cabe a ele, portanto, demonstrar que estão presentes os requisitos do artigo 593 do CPC e, na hipótese em que é relevante o elemento subjetivo (art. 593, II, sem averbação no registro público), também deverá fazer prova da má-fé do terceiro, demonstrando que ele tinha razão para saber da pendência da ação.

Inversamente, decretada a fraude de execução e constrito o bem, a matéria será discutida em embargos de terceiro, cabendo ao terceiro, como autor dos embargos, o ônus de provar os fatos constitutivos de seu direito de desconstituir a penhora sobre seu bem, inclusive - na hipótese sob análise - a sua boa-fé, demonstrando que, apesar de sua diligência, não teve razão para saber da ação pendente.

Nesse sentido, afirma PAulo Henrique dos SAntos Lucon que "fora do processo executivo e mediante o oferecimento de embargos, o terceiro deverá alegar e

\footnotetext{
${ }^{283}$ Cf., por todos, LEONEL, Ricardo de Barros. Reformas recentes do processo civil, cit., p. 37.

${ }^{284}$ BARBOSA MOREIRA, José Carlos. Presunções e prova, cit., p. 60-61.
} 
demonstrar a sua boa-fé e a conseqüente idoneidade do ato jurídico. (...) Por outro lado, deve ser sempre lembrado que, in executivis, compete sempre a quem alega a fraude de execução o ônus da prova da ciência dos adquirentes da pendência de processo capaz de conduzir o alienante à insolvência." 285

Nota-se, portanto, que a duplicidade da incidência da regra geral da distribuição do ônus da prova decorre de a questão ser discutida em dois processos. No processo de execução, incide por força dos artigos 333 cumulado com 598 do CPC e nos embargos de terceiro, pela conjugação do mesmo artigo 333 com o artigo 272 do CPC. Já a inversão do credor quanto ao ônus da prova desse mesmo fato num e noutro processo, decorre de sua inversão na posição processual invertida: no processo principal, figurará no polo ativo e, nos embargos de terceiro, estará no polo passivo.

Diferente seria se houvesse uma regra específica atribuindo o ônus da prova desse fato a tal ou qual litigante, ${ }^{286}$ ou se houvesse presunção legal relativa que abrangesse essa hipótese e se baseasse em fato verificável mais facilmente na generalidade das situações. Como ocorre, por exemplo, com a presunção de insolvência do artigo 750, I e II, do CPC, que deriva do fato de o devedor não possuir outros bens sujeitos à penhora ou de terem sido arrestados seus bens nas hipóteses do artigo 813, I a III do CPC.

É verdade que diversos autores e julgados sustentam haver presunção relativa de má-fé do terceiro em razão da pendência da ação. ${ }^{287}$ Embora esse entendimento

\footnotetext{
${ }^{285}$ LUCON, Paulo Henrique dos Santos. Fraude à execução, responsabilidade processual civil e registro da penhora, cit., p. 135. Também nesse mesmo sentido, embora referindo ao ônus da prova da insolvência, cf. Dinamarco, revendo sua posição anterior após melhor reflexão sobre a obra de Yussef Said Cahali: "o onus probandi é realmente do autor, até mesmo porque a insolvência integra a fattispecie conducente à inoponibilidade do ato (CPC, art. 333, inc. I). (...) É claro que, nos embargos de terceiro do adquirente contra a penhora em caso de alegado fraude de execução, constitui sempre ônus do autor a prova da existência de bens suficientes no patrimônio do devedor: nesse caso, o equilíbrio patrimonial é que comparece como fato constitutivo do direito do demandante." (DINAMARCO, Cândido Rangel. Execução civil, cit., p. 278-279).

${ }^{286}$ É, por exemplo, o que ocorre no artigo $611^{\circ}$ do Código Civil no Português, referente à impugnação pauliana: "incumbe ao credor a prova do montante das dívidas, e ao devedor ou a terceiro interessado na manutenção do acto a prova de que o obrigado possui bens penhoráveis de igual ou maior valor."

${ }^{287} \mathrm{Cf}$., por exemplo, entre os que engrossam as fileiras das posições intermediárias citadas na introdução desta tese, José Eli Salamacha: "haverá presunção relativa em benefício do credor (autor), podendo ser declarada de imediato a fraude à execução, se a demanda tramitar na mesma comarca em que se localizar o imóvel litigioso ou no domić́lio do alienante, cabendo ao adquirente provar o contrário por meio dos embargos de terceiro. (...) Se, no entanto, a demanda não correr na mesma comarca em que se localizar o imóvel objeto da alienação ou oneração, ou no domicílio do alienante, entendemos que a presunção relativa deva correr em favor do adquirente" (SALAMACHA, José Eli. Fraude de execução: direitos do credor e
} 
aponte para uma realidade desejável, carece ele de respaldo legal e, no caso dos julgados, cria situação de instabilidade jurídica que conspira contra a administração da justiça e a confiabilidade do próprio Poder Judiciário.

Válida, portanto, a esse respeito, a advertência de Flávio LuIZ YARSHELL, de que "as normas sobre o ônus da prova devem ser determinadas de antemão e independentemente da situação processual concreta, acentuando-se que a distribuição do ônus de prova pela lei é fator de segurança jurídica." e mais adiante reafirma: "a distribuição do ônus da prova é tarefa precípua do legislador, e apenas secundariamente do juiz, quando expressamente autorizado por aquele." 288

Por fim, registre-se que, além de não ser confirmado à luz da legislação vigente, uma vez que, fora das hipóteses dos artigos $659, \S 4^{\circ}, 615-\mathrm{A}$, vigora a regra geral de distribuição do ônus da prova (arts. 333, c/c 598 ou 272, CPC), o entendimento dominante impõe ao credor ônus de prova dificílima, o que limita muito o âmbito da verificação da ocorrência da fraude de execução. ${ }^{289}$

Encerrando esse capítulo, verifica-se, portanto, que, nos quatro pontos em que se confronta com o entendimento dominante, a hipótese defendida nesta tese apresenta-se mais adequada à legislação em vigor sobre a matéria, apresentando ainda vantagens relevantes para a aplicação do instituto da fraude de execução.

do adquirente de boa-fé, cit., p. 163-164) e um dos recentes acórdãos proferidos pelo Superior Tribunal de Justiça antes da súmula 375:"o inciso II, do art. 593, do CPC, estabelece uma presunção relativa da fraude, que beneficia o autor ou exequiente, razão pela qual é da parte contrária o ônus da prova da inocorrência dos pressupostos da fraude de execução" (STJ, $3^{\text {a }}$ T., REsp 618.625/SC, rel. Min. Nancy Andrighi, j. 19.02.08).

${ }^{288}$ YARSHELL, Flávio Luiz. Antecipação da prova sem o requisito da urgência e direito autônomo à prova. São Paulo: Malheiros Ed., 2009. p. 87 e 89.

${ }^{289}$ Basta verificar que, entre os únicos casos em que, considerando-se relevante o elemento subjetivo, a fraude de execução foi reconhecida, a má-fé fé do terceiro constava de prova irrefragável, como no Resp 555.044DF, em que a escritura pública da alienação constava registro da existência da citação e houve notícia do depoismento do corretor de imóveis atestando que os terceiros sabiam da existência da ação e de suas possíveis consequências para o negócio. 


\section{6- O EFEITO DO RECONHECIMENTO DA FRAUDE DE EXECUÇÃO: INOPONIBILIDADE DO LIMITE PATRIMONIAL DO TERCEIRO À ATIVIDADE EXECUTIVA}

Verificamos, nos dois capítulos anteriores, que a hipótese aqui proposta mostra-se mais fiel à história da fraude de execução, resgatando quase que totalmente a feição e a relevância que o elemento subjetivo tinha quando o instituto foi originalmente criado no direito brasileiro. Vimos também como nossa hipótese mostra-se mais adequada que o entendimento dominante em relação às normas vigentes sobre a matéria. $\mathrm{O}$ que se pretende fazer, neste sexto capítulo, é demonstrar como nossa hipótese - em especial no ponto em que se sustenta que somente a má-fé do terceiro é relevante para a configuração da fraude de execução - também está em consonância com a evolução e o estado atual da ciência processual em relação à responsabilidade executória, em que o tema se insere.

Embora trate também do estágio atual quanto à matéria, o presente capítulo está longe de repetir os argumentos expostos no capítulo anterior, em que a análise foi feita à luz da legislação atual. Até mesmo porque, embora já estejamos nos aproximando da marca de um século e meio desde a célebre obra de BRINZ e a divisão entre débito e responsabilidade não se afigure mais novidade para qualquer estudioso do Direito, os ordenamentos jurídicos ainda não assimilaram totalmente essa visão, mantendose arraigados a disciplina e dispositivos tradicionais sobre a matéria.

Evidência desse fato são as diversas disposições sobre responsabilidade executória previstas em códigos ou leis dedicados - ao menos preponderantemente - ao direito material, como os artigos 158 e seguintes do CC, que dispõem sobre a fraude contra credores, tratando-a como caso de anulabilidade do ato jurídico, ou o artigo 391 do CC, que repete a regra da responsabilidade executória primária já existente no 591 do CPC. ${ }^{290}$

\footnotetext{
${ }^{290}$ Tal fato não é exclusividade do ordenamento jurídico brasileiro. Como se mostram os dispositivos italianos e portugueses citados na introdução desta tese, em que até mesmo a ineficácia da alienação de bem penhorado é tratada nos Códigos Civis daques países. A análise histórica feita no capítulo 4, infra, mostrou, contudo, que tivemos dispositivos de conteúdo verdadeiramente processual - uma vez que completavam, restringiam ou condicionavam outros dos códigos processuais dedicados a hipóteses de responsabilidade executória secundária - tratados na legislação de registros públicos. Tal fato, porém deu-
} 
Especificamente em relação ao tema objeto desse capítulo, observa-se que, enquanto para a fraude contra credores a lei prevê expressamente que seu efeito é a anulação e a doutrina discute se tal efeito seria anulação ou ineficácia; para a fraude de execução, é praticamente pacífico na doutrina que seu efeito seria a ineficácia do ato em relação ao credor, embora a lei nada disponha nesse sentido.

É a lição que se colhe de SÁlVIO DE FIGUEIREDO TEIXEIRA, ao afirmar que "a alienação ou oneração do bem em fraude de execução não é inexistente, nula ou anulável, mas ineficaz, isto é, embora válida entre alienante e adquirente ou beneficiário, não produz efeitos em relação ao credor" ${ }^{291}$ e que, na mesma linha, complementa José ELI SALAMACHA que "o ato é ineficaz relativamente a credor, permanecendo válido o negócio jurídico entre devedor alienante e terceiro adquirente. ${ }^{292}$

De maneira um pouco diversa, sustenta DinAMARCo que o efeito do reconhecimento da fraude de execução seria a "ineficácia parcial" ou a "infra-eficácia", pois "não priva o negócio jurídico integralmente de sua eficácia", atingindo apenas o "efeito secundário" de "excluir o bem alienado do acervo que constitui a garantia geral pelas obrigações do alienante". Ainda segundo o autor, o ato seria "atacado de ineficácia relativa" ou "inoponibilidade" em relação ao credor. ${ }^{293}$

Para que se compreenda em sua integralidade a posição de DinAMARCO, deve-se observar, ainda, que o autor sustenta que tal ineficácia parcial e relativa decorre tanto do reconhecimento da prática de ato em fraude de execução quanto em fraude contra credores. A diferença entre as duas seria apenas que, na fraude de execução, a ineficácia seria originária, pois não seria necessária uma ação para vê-la reconhecida. Já na fraude

\footnotetext{
se em razão de uma maior praticidade ou conveniência identificada por Philadelpho Azevedo, como será visto quando voltarmos ao tema no capítulo 9, infra.

${ }^{291}$ TEIXEIRA, Sálvio de Figueiredo. Fraude de execução, cit., p. 8.

${ }^{292}$ SALAMACHA, José Eli. Fraude de execução: direitos do credor e do adquirente de boa-fé, cit., p. 151.

${ }^{293}$ Cf. DINAMARCO, Cândido Rangel. Execução civil, cit., p. 264 e 268-269, respectivamente. A lição é aceita integralmente por Frederico Fontoura da Silva Cais ao sustentar que tal ineficácia seria "parcial, porque o negócio jurídico produz seu efeito primário de transmitir o domínio do bem, ou seja, a transmissão é plenamente válida e eficaz, porém o negócio jurídico inquinado pela fraude não produz seu efeito secundário, consistente em excluir a responsabilidade do bem pelas obrigações de quem o aliena. Relativa, porque somente perante o credor é que o ato se considera ineficaz." (CAIS, Frederico Fontoura da Silva. Fraude de execução, cit., p. 143).
} 
contra credores, seria ulterior, eventual ou sucessiva, porque dependeria de seu reconhecimento por meio da ação pauliana. ${ }^{294}$

Temos para nós, contudo, que a tentativa de se procurar explicar o efeito do reconhecimento da fraude de execução sobre o ato jurídico de direito material em nada contribui para o aclaramento da matéria. Ao contrário, apenas gera mais dificuldade de compreensão sobre instituto que já não é simples.

Assim, entendemos que a estratégia mais adequada para se compreender o efeito do reconhecimento da fraude de execução é atacar a questão pela perspectiva da responsabilidade que recai sobre o bem objeto do ato obrigacional e não sobre o ato em si.

Com isso, desloca-se a discussão do plano do direito material para o plano do processo, em que se inserem as hipóteses de responsabilidade executória secundária e, entre elas, as dos bens alienados ou onerados em fraude de execução. ${ }^{295}$ Como ensina LiEBMAN, "a responsabilidade, ao invés de ser elemento da relação jurídica obrigacional, (...) é vinculo de direito público processual, consistente na sujeição dos bens do devedor [ou de terceiros] a serem destinados a satisfazer o credor, que não recebeu a prestação devida, por meio da realização da sanção por parte do órgão judiciário." 296

\footnotetext{
${ }^{294}$ E complementa o autor: "nisso reside a grande diferença da fraus pauliana em face da fraude de execução: é do credor o ônus de postular em juízo a retirada da eficácia secundária do ato realizado em fraude a credores, de modo que, por força da sentença (constitutiva) dada na actio pauliana, aquela responsabilidade excluída por força da alienação se restabeleça e se possa então obter a penhora. É como se vê, uma ineficácia eventual ou sucessiva essa que somente sobrevirá se e quando vier a ser proferida a sentença favorável ao credor (não ineficácia originária, como na fraude de execução)." (DINAMARCO, Cândido Rangel. Execução civil, cit., p. 274-275). Em sentido semelhante quanto à natureza da sentença na ação pauliana, cf. Paulo Henrique dos Santos Lucon: "uma vez procedente a demanda, cria-se uma situação jurídica nova (eficácia constitutiva positiva), restabelecendo a responsabilidade do bem pelas obrigações assumidas pelo alienante e permitindo sua excussão." (LUCON, Paulo Henrique dos Santos. Fraude à execução, responsabilidade processual civil e registro da penhora, cit., p. 132).

Em sentido oposto, defendendo a natureza declaratória da sentença da ação pauliana, cf. THEODORO JÚNIOR, Humberto. Fraude contra credores: a natureza da sentença pauliana, cit., p. 242; HANADA, Nelson. Da insolvência e sua prova na ação pauliana, cit., p. 92.

${ }^{295} \mathrm{Em}$ rigor, entendendo-se que sua eficácia seria igual à da fraude de execução, aqui também deveriam estar incluídos os bens alienados em fraude contra credores. No entanto, seja em razão das normas do Código Civil (arts. 158 e ss.), seja em razão das normas do Código de Processo Civil, em especial o rol - taxativo do art. 592, que prevê os casos excepcionais de responsabilidade executória secundária, não há como sustentar tal posicionamento senão contra legem.

${ }^{296}$ LIEBMAN, Enrico Tullio. Processo de execução, cit., p. 37, sem colchetes no original.
} 
Dessa forma, tanto a afirmação mais simples, de que o ato de alienação seria "ineficaz em relação ao credor", quanto a mais complexa de que o ato seria "ineficaz parcial, relativa e originariamente em relação ao credor", correspondem, no plano do direito processual, à declaração de que o bem permanece sujeito à atividade executiva decorrente do processo no curso ainda que em patrimônio de terceiro. Ou, mais tecnicamente, que o vínculo da responsabilidade executória pelo cumprimento forçado da obrigação objeto daquela ação pendente não abandona o bem alienado se tal alienação se der em alguma das circunstâncias previstas em lei como fraude de execução.

Por força da regra geral da responsabilidade executória, prevista no artigo 591 do CPC, a atividade executiva deve se realizar sobre bens existentes dentro dos limites patrimoniais do devedor. Se o ato transfere o bem para o patrimônio de um terceiro, os limites patrimoniais deste constituem barreira que, em regra, salvaguarda tal bem da atividade executiva estatal. Diz-se "em regra" porque as exceções são precisamente os casos de responsabilidade executória secundária previstos no artigo 592 do mesmo código.

Ao se dizer que o efeito da fraude de execução é a ineficácia do ato de alienação em relação ao credor o que se faz é tentar exprimir fenômeno existente no plano do direito processual vendo-o pelo ângulo do direito material. O que se quer exprimir, na realidade, é a inoponibilidade do limite do patrimônio do terceiro em relação à atividade executiva decorrente de processo específico sobre um ou mais bens também específicos.

Ao se tentar descrever o fenômeno como ineficácia do ato de direito material logo avultam as falhas de tal descrição e a necessidade de melhor detalhá-la, como bem se observa na lição de DINAMARCO ao descrevê-la como uma ineficácia parcial, relativa e originária. Contudo, ainda sua descrição está incompleta, pois nos parece que, visto o problema pelo plano material, dever-se-ia falar, na realidade, de uma ineficácia duplamente relativa e condicionada. 
Explica-se: inicialmente, a ineficácia seria relativa por se limitar a atingir a apenas um dos efeitos do ato de alienação, qual seja, o efeito processual de excluir o bem da responsabilidade do devedor; seria o "efeito secundário" descrito por DINAMARCO. ${ }^{297}$

Em segundo lugar, dir-se-ia também relativa tal ineficácia do ato porque limitada à atividade executiva decorrente daquele processo em curso que seria frustrada se o ato produzisse todos os seus efeitos. É sob esse aspecto que, equivocadamente, se diz que o ato é ineficaz em relação ao credor.

Não é o que se passa. A ineficácia ou inoponibilidade não tem como beneficiário o credor, pessoalmente, e sim a atividade executiva estatal. ${ }^{298}$

Ora, se o ato fosse ineficaz ou inoponível em relação ao credor, este, possuindo duas execuções em curso, poderia invocar a ineficácia do ato declarada na primeira para permitir a penhora do bem de terceiro também na segunda, ainda que nessa não estivessem presentes os requisitos ensejadores da fraude de execução. ${ }^{299} \mathrm{Da}$ mesma forma, fosse a ineficácia do ato limitada em relação ao credor, pessoalmente, dela não se

${ }^{297}$ Cf. DINAMARCO, Cândido Rangel. Execução civil, cit., p. 264. Contudo, não parece adequado rotular tal efeito de "secundário", principalmente em oposição ao que seria o "efeito primário" da alienação no plano do direito material, qual seja, privação do devedor e outorga ao adquirente de todos os direitos de uso, gozo e disposição do bem. Poder-se-ia dar a impressão de que o direito processual seria secundário em relação ao direito material. $\mathrm{O}$ efeito de excluir o bem da responsabilidade executória nada mais é que o efeito processual de toda alienação, pois essa retira o bem do patrimônio do devedor e o coloca em patrimônio de terceiro.

Tem razão, contudo, Dinamarco ao afirmar que tal efeito seria "não programado" pelos contratantes no negócio jurídico de alienação, pois, de fato, tal efeito decorre da lei processual, que é de ordem pública, e independe da vontade das partes.

${ }^{298}$ Em sentido similar, cf. José Carlos Barbosa Moreira, dizendo que a "alienação é válida e produz efeito entre as partes do contrato, embora permaneça relativamente ineficaz, no sentido de não obstar que o bem seja atingido pela exесис̧ão." (BARBOSA MOREIRA, José Carlos. O novo processo civil brasileiro. 21. ed. Rio de Janeiro: Forense, 2001. p. 227 - somente com os primeiros destaques no original); Teresa Arruda Alvim Wambier, que cita como exemplo de inoponibilidade "o ato praticado em fraude à execução, cuja eficácia não se opera em detrimento do resultado do processo." (WAMBIER, Teresa Arruda Alvim. Nulidades do processo e da sentença. 6. ed. São Paulo: Ed. Revista dos Tribunais, 2007. p. 139, nota 12 sem destaques no original); e, também, Luiz Fux ao afirmar que "a lei simplesmente ignora a venda, reputando-a 'ineficaz' em relação ao processo, com o que permite ao Estado-juiz atingir o bem no patrimônio de quem não é o devedor, mas responsável secundário" em fenômeno que sugestivamente denominou de "insensibilidade processual da transmissão do domínio" (FUX, Luiz. O novo processo de execução: o cumprimento da sentença e a execução extrajudicial, cit., p. 94 - com destaques no original).

${ }^{299}$ Assim, por exemplo, poder-se-ia imaginar caso em que o ato de alienação ocorreu após o ajuizamento da primeira execução, mas antes do ajuizamento da segunda execução promovida pelo mesmo credor. Se fosse válido o entendimento de que a ineficácia do ato beneficiaria o credor, pessoalmente, este poderia utilizarse dessa ineficácia também no segundo processo, penhorando os bens alienados a terceiro em decorrência daquele ato, independente o reconhecimento da fraude contra credores ou de execução. 
aproveitariam os sucessores, cessionários ou subrogados que poderiam prosseguir na execução já em curso (art. 567, CPC), o que não é verdadeiro. ${ }^{300}$

Por fim, dir-se-ia que tal ineficácia seria condicionada, pois estaria sujeita à condição resolutiva de não se verificar a frustração da atividade executiva que se antevia no momento da prática do ato, seja porque a própria ação pendente jamais chegou à fase executiva, sendo extinta antes, seja porque, no momento da execução, o bem objeto do direito real havia retornado ao patrimônio do devedor (na hipótese do art. 593, I, $\mathrm{CPC})^{301}$ ou os bens nele existentes - sujeitos à responsabilidade executória primária, portanto - seriam suficientes para safisfazer o crédito (na hipótese do art. 593, II, CPC). ${ }^{302}$

Em outras palavras, a ineficácia do ato de alienação praticado em fraude de execução somente existiria, portanto, enquanto permanecesse pendente a ação no curso da qual foi praticado e, ao mesmo tempo, no caso do artigo 593, II, do CPC, enquanto permanecessem insuficientes os bens sujeitos à responsabilidade executória primária (bens existentes no próprio patrimônio do devedor - art. 591, CPC).

Pode causar estranheza considerar que o ato, originalmente ineficaz, alcançaria sua eficácia supervenientemente. ${ }^{303}$ No entanto, poder-se-ia dizer, nas palavras

\footnotetext{
${ }^{300}$ Ao menos em relação à ineficácia decorrente do reconhecimento de fraude contra credores, assim já se pronunciou CAHALI, Yussef Said. Fraudes contra credores, cit., p. 162.

${ }^{301}$ A situação é cerebrina, mas pode ocorrer. Imagine-se, por exemplo, um bem alienado com pacto de retrovenda ou uma doação feita a filho que venha a falecer, sem deixar descendentes, no curso da ação.

${ }^{302}$ Também aqui, embora não seja muito comum, pode acontecer de o devedor melhorar sua situação patrimonial entre o momento da prática do ato de alienação e o momento do exercício da atividade executiva pelo credor. Nesse caso, embora o ato efetivamente tenha ocorrido em fraude de execução, isto é, tenha sido praticado no curso de uma ação que poderia tornar o devedor insolvente, não se verificando essa insolvência no momento da concretização da atividade executiva, o bem não poderá ser por ela alcançado, pois a responsabilidade executória secundária decorrente dessa segunda hipótese de fraude de execução é subsidiária.

${ }^{303}$ A mesma estranheza em relação a esse fenômeno foi sentida por Dinamarco, mas em relação à fraude contra credores, em que essa ineficácia também estaria condicionada ao decurso do prazo prescricional de quatro anos, previsto no artigo $178 \mathrm{de}$ CC/02. Deparando-se com ela, o autor foi levado a afirmar que o ato praticado em fraude contra credores seria, em princípio, plenamente eficaz e só perderia essa eficácia se, em quatro anos, a ação pauliana fosse ajuizada e julgada procedente, dizendo em seguida que "seria muito estranho dizer o inverso, ou seja, que o ato após os quatro anos ganharia uma eficácia que antes não tinha." (DINAMARCO, Cândido Rangel. Execução civil, cit., p. 274). Foi esse entendimento que o levou a sustentar, noutra oportunidade, que a sentença, na ação pauliana, seria uma sentença desconstitutiva da eficácia secundária do ato. Nas palavras do próprio autor: "o negócio fraudulento é originalmente eficaz e só uma sentença constitutiva negativa tem o poder de lhe retirar a eficácia prejudicial ao credor." (DINAMARCO, Cândido Rangel. Fraude contra credores alegada nos embargos de terceiro. In: Fundamentos do processo civil moderno. 3. ed. São Paulo: Malheiros, 2000. v. 1, p. 567).
} 
de LiEBman, que tal estranheza decorre da "dificuldade para exprimir este efeito meramente processual com os conceitos usuais do direito privado." ${ }^{304}$

Como contraprova ao que se expôs acima, sugere-se a seguinte reflexão: como explicar-se-iam os demais casos de responsbilidade executória secundária sob a ótica da ineficácia do ato jurídico de direito material? Na desconsideração da personalidade jurídica, o ato de constituição da pessoa jurídica - o contrato ou estatuto social, por exemplo - seria considerado ineficaz em relação ao credor? E na hipótese de responsabilidade do cônjuge, o casamento ou apenas a opção pelo regime de bens seriam considerados ineficazes em relação ao credor? Quantos e quais adjetivos teríamos de utilizar para qualificar tais casos de ineficácia? Não seria mais simples enunciar apenas que os limites patrimoniais do sócio ou do cônjuge não poderiam ser opostos à atividade executiva do Estado, nessas situações expressamente previstas em lei?

O ideal, portanto, para compreender o fenômeno do efeito da fraude de execução, é tentar vê-lo não pelo ângulo do direito material, onde está o ato jurídico, mas frente a frente, do plano do direito processual. Neste plano, não se encontram as pessoas do credor, do devedor ou do terceiro adquirente do bem e o ato de alienação, mas apenas seus patrimônios com os bens neles inseridos e a atividade executiva estatal. ${ }^{305}$

Assim, pela regra geral enunciada atualmente pelo artigo 591 do CPC, repetida desnecessariamente no artigo 391 do CC, somente os bens existentes no patrimônio do devedor serão objeto da atividade executiva. Os existentes no patrimônio de terceiro não estão sujeitos a ela. Em outras palavras, o limite do patrimônio do terceiro representa obstáculo que impede a atividade executiva de alcançar os bens nele inseridos para o cumprimento forçado da obrigação do devedor.

No entanto, os artigos 592, V, e 593 do CPC preveem que, excepcionalmente, nos casos em que o ingresso do bem no patrimônio do terceiro adquirente se deu em situação descrita em lei como fraude de execução, tal bem poderá ser alcançado pela atividade executiva ainda que esteja no patrimônio de terceiro.

\footnotetext{
${ }^{304}$ LIEBMAN, Enrico Tullio. Processo de execução, cit., p. 106.

${ }^{305}$ É o que, singelamente, procurou-se ilustrar na Figura 3 do Apêndice 3 desta tese.
} 
Pode-se dizer, assim, que o limite do patrimônio do terceiro adquirente será inoponível a essa atividade executiva que seria frustrada pelo ato praticado em fraude de execução e não a outra. Extrai-se dessa exposição, ainda, que considerar inoponível o limite patrimonial do terceiro não significa considerá-lo "como se não existisse", respondendo todos os bens deste em relação a todas as obrigações do devedor.

O efeito é relativo àquela determinada atividade executiva que seria frustrada pela saída do bem do patrimônio do devedor e àquele determinado bem que ingressou, em fraude de execução, no patrimônio de terceiro. ${ }^{306}$

A consequência da declaração de que o ato de alienação foi praticado em fraude de execução consiste, portanto, no reconhecimento de que o liame de direito público que liga a sujeição do bem (responsabilidade) à sanção executiva do Estado não foi rompido em razão do ingresso do bem em patrimônio de terceiro.

Nota-se, portanto, que o efeito do reconhecimento da fraude de execução não atinge o ato de direito material em si mesmo, o que poderia justificar a exigência da má-fé do devedor como partícipe do ato. Ao contrário, visto mais adequadamente, sob a ótica da responsabilidade executória, verifica-se que tal efeito se faz sentir apenas no patrimônio do terceiro, sendo absolutamente irrelevante ao patrimônio do devedor. ${ }^{307}$

Assim, ao sustentar que o elemento subjetivo relevante para a fraude de execução não inclui a má-fé do devedor, como exige o entendimento dominante, nossa hipótese está se alinhando com a visão da questão pelo ângulo do direito processual e de acordo com a perspectiva da responsabilidade executória.

\footnotetext{
${ }^{306}$ Valendo-se de imagem tirada da Biologia, pode-se dizer que o limite patrimonial, regido pelas normas de responsabilidade executória primária e secundária, funciona, no caso de fraude de execução, como a membrana plasmática, por ser semipermeável ou possuir permeabilidade seletiva, controlando o que entra ou sai da célula (cf. CAMPBELL, Neil A. Biology. 4. ed. Menlo Park: Benjamin; Cummings, 1996, p. 140 e ss.)

${ }^{307}$ Em relação a essa última conclusão, cf. Dinamarco que, em certa contradição com suas passagens antes citadas, sustenta que, na ação pauliana, "a legitimidade passiva é exclusiva do adquirente do bem, cuja esfera de direitos poderá resultar desfalcada se a demanda do credor vier a ser julgada procedente e, conseqüentemente, o bem adquirido puder ser submetido à penhora. $\mathrm{O}$ art. 161 do Código Civil insinua a legitimidade conjunta do devedor, ou mesmo um litisconsórcio necessário com o adquirente, mas isso não tem razão de ser porque em nada ficará afetado o seu patrimônio se a ação pauliana for julgada procedente e o bem puder ser penhorado; é rigorosamente indiferente para sua esfera de direitos que esse resultado seja obtido ou não" (DINAMARCO, Cândido Rangel. As fraudes do devedor, cit., p. 439).
} 


\section{7- AS CINCO VARIÁVEIS DA FRAUde DE EXECUÇÃo E SUA RELAÇÃO COM O ELEMENTO SUBJETIVO: PROPOSTA DE METODOLOGIA PARA ANÁLISE DA CONFIGURAÇÃo DE FRAUDE DE EXECUÇÃO}

Demontrada nossa hipótese nos capítulos anteriores e verificadas as suas vantagens em relação ao entendimento dominante, apresentamos aqui proposta de metodologia para aferir se o ato foi praticado ou não em fraude de execução, com base na feição do elemento subjetivo como a má-fé apenas do terceiro, decorrente da existência de razão para que ele soubesse da demanda, e na circunscrição do exame da presença desse elemento subjetivo apenas às hipóteses em que ele é relevante (art. 593, II, CPC, sem que conste notícia da pendência da ação em registros públicos).

A exposição será feita passando por cinco variáveis que influenciam na fraude de execução, quais sejam, (i) a ação pendente; (ii) o ato praticado em seu curso; (iii) o bem objeto desse ato; (iv) o momento processual em que o ato foi praticado; e (v) as pessoas envolvidas, em especial o terceiro, se imediato ou mediato.

A ordem dessas variáveis foi escolhida de modo que o intérprete analise primeiro a presença do elemento objetivo da fraude de execução, qual seja, a possibilidade de o ato frustrar a atividade executiva decorrente do processo em curso e, em seguida, o elemento subjetivo que, como demonstramos acima, sequer é exigido em todos os casos. ${ }^{308}$

\section{1- Ação fundada em direito real ou que possa reduzir o devedor à insolvência}

As ações no curso das quais os atos de alienação ou oneração de bens podem ser praticados em fraude de execução são, como visto no item 2.3, supra, a ação fundada em direito real (art. 593, I, CPC) e a ação que possa ensejar execução de obrigação de pagar quantia (art. 593, II, CPC). ${ }^{309}$

\footnotetext{
${ }^{308} \mathrm{Na}$ Figura 4 do Apêndice 3, apresenta-se fluxograma com os passos a serem percorridos na análise.

${ }^{309}$ Mantém-se aqui, portanto, a restrição à análise das duas hipóteses descritas nesses dois incisos, como já mencionamos ao final do item 2.4, supra.
} 
Dependendo de qual delas estiver pendente quando da prática do ato, este poderá ou não ser capaz de frustrar a sua atividade executiva.

Para a primeira, a frustração da atividade executiva se dá pela alienação ou oneração do próprio bem objeto da pretensão (não importa se a alienação foi gratuita ou onerosa, ainda que pelo valor de mercado do bem).

Para a segunda, a frustração da atividade executiva se dá pela insolvência do devedor ou, mais tecnicamente, pela inexistência, em seu patrimônio, de bens passíveis de serem penhorados naquela execução.

Imagine-se, em primeiro lugar, a hipótese de fraude de execução prevista no inciso I do artigo 593 do CPC, em que o ato de alienação é praticado na pendência de ação fundada em direito real, uma ação reivindicatória, por exemplo. Nesse caso, a alienação do próprio bem objeto da ação, gera, independentemente de qualquer análise referente ao patrimônio do devedor, a frustração da atividade executiva, pois esta teria por objeto aquele bem específico e não qualquer outro. ${ }^{310}$

Imagine-se agora a hipótese prevista no inciso II do artigo 593 do CPC, em que o ato é praticado estando em curso uma "ação capaz de reduzir o devedor a insolvência". Nesse segundo caso, a frustração da atividade executiva decorreria do fato de a alienação ter deixado o patrimônio do devedor sem bens suficientes sobre os quais poderia recair a penhora.

Nessa segunda hipótese, há que se ter em conta que, dependendo da obrigação em que se funde a ação, alguns bens poderão ou não estar sujeitos à penhora, ${ }^{311}$ de modo que a "insolvência" mencionada genericamente no artigo 593, II, CPC deve ser

\footnotetext{
${ }^{310}$ É o que Liebman mencionou como "bens que são o objeto final da execução" (cf. LIEBMAN, Enrico Tullio. Processo de execução, cit., p. 109).

${ }^{311}$ Como exemplos, basta lembrar o caso visto no item 2.3.3.4, supra, em que a impenhorabilidade do bem de família não é oponível para as execuções fundadas nas obrigações previstas no artigo $3^{\circ}$ da Lei n. ${ }^{\circ}$ 8.009/1990. Ou, ainda, o caso de uma obrigação garantida por hipoteca de terceiro, em que o conjunto de bens sujeitos à execução abrangerá não só os bens do devedor, mas também o imóvel de terceiro.
} 
interpretada de forma mais estrita, como a insuficiência de bens sujeitos à penhora naquela execução específica. ${ }^{312}$

Para verificar, portanto, se o ato praticado teria capacidade de frustrar a atividade executiva, deve-se analisar, de início, qual seria a atividade executiva que a ação pendente ensejaria: entrega de coisa certa ou pagamento de quantia e, nesse último caso, em quais dos bens especificamente poderia recair a atividade executiva.

\section{2- Ato de alienação ou oneração do bem}

Em seguida, deve-se analisar qual o tipo do ato cuja prática se está querendo reconhecer em fraude de execução, pois a diferença de seus efeitos também terá influência em sua capacidade de frustrar a atividade executiva.

É certo, contudo, que, entre o universo de atos que poderiam ser praticados para frustrar a atividade executiva, ${ }^{313}$ o CPC considerou que apenas dois tipos de ato poderiam ser praticados em fraude de execução: alienação ou gravação com ônus real (cf. arts. 592, V, e 593, caput, CPC).

Como já visto anteriormente, a responsabilidade que recai sobre os bens alienados ou gravados em fraude de execução é excepcional (responsabilidade executória secundária) e, como tal, deve ser interpretada restritivamente. ${ }^{314}$

\footnotetext{
${ }^{312}$ Nessa linha, Dinamarco afirma que "o patrimônio levado em conta para medir a solvência ou insolvência quando se trata de responsabilidade executiva é o conjunto de todos os bens economicamente apreciáveis do obrigado, não excluídos da responsabilidade por motivo algum (impenhorabilidades etc. ...); tanto é insolvente aquele que nada tem, ou pouco tem para responder por suas obrigações, como aquele que for dono de bens com valor acima dos débitos mas que por força de lei ou de algum ato particular estejam subtraídos à execução forçada (os bens de família, os dados em garantia real etc. ...)." (DINAMARCO, Cândido Rangel. As fraudes do devedor, cit., p. 433). Também em sentido semelhante, Araken de Assis: "no âmbito da fraude contra a execução (...), dispensável se revela a investigação do estado deficitário do patrimônio, bastando a inexistência de bens penhoráveis. Daí a noção mais adequada de frustração dos meios executórios." (ASSIS, Araken de. Manual do processo de execução, cit., p. 450-451).

${ }^{313}$ Como a destruição, a danificação ou o desvio de bens, apenas para se ficar nos citados pelo art. 179, CPC.

${ }^{314}$ Discorda-se, nesse ponto, de autores como Francisco Antonio Casconi, que sustentam que "certos atos, ainda que não enquadrados na figura da alienação ou oneração, podem igualmente representar fraude à execução. (...) Nestes termos, a indicação do art. 593, caput, seria apenas exemplificativa." (CASCONI, Francisco Antonio. Fraude de execução. In: HARADA, Kiyoshi (Coord.). Temas de processo civil. São Paulo: Juarez de Oliveira, 2002. p. 110).
} 
Ensina AMÍlCAR DE CASTRO que "compreende-se sob o nome de alienação todo e qualquer ato entre vivos pelo qual o devedor dispõe, a favor de terceiro, de bem que lhe pertence, por meio de transferência, ou renúncia". ${ }^{315}$ Nesse sentido, também a lição de MÁrio AguiAr Moura: “em matéria de alienação tem-se como suscetíveis de embasar o requisito: a) compra e venda; b) doação; c) cessão de crédito; d) remição de dívida; e) dação em pagamento. Incluem-se, ainda, outros atos que mesmo não sendo tipicamente de transferência de domínio, desfalcam o patrimônio do devedor, tais como renúncia de prescrição e renúncia de herança." 316

Os atos de alienação frustram a atividade executiva por retirarem os bens do patrimônio do devedor e os colocarem no patrimônio de terceiro, pondo-os a salvo, portanto, da responsabilidade que recai genericamente sobre todo o patrimônio do devedor para o satisfação coativa de suas obrigações.

Já a "gravação com ônus reais" abrange a instituição, sobre o bem, de direitos reais de garantia (como hipoteca, penhor e anticrese), de direitos reais de fruição (como superfície, servidão, usufruto, uso e habitação) ou, ainda, outros gravames reais como o direito do promitente comprador, denominado por alguns autores como "direito real de aquisição". 317

Tais gravames podem atuar de duas formas para frustrar a atividade executiva: ( $i$ ) ou constituem preferência sobre o bem em relação ao credor (direitos reais de garantia); ${ }^{318}$ ou (ii) retiram valor do bem, mediante a limitação de parte dos poderes do domínio, tornando-o insuficiente para satisfazer toda a obrigação objeto da execução. ${ }^{319}$

\footnotetext{
${ }^{315}$ CASTRO, Amílcar de. Comentários ao Código de Processo Civil, cit., v. 8, p. 81.

${ }^{316}$ MOURA, Mário Aguiar. Fraude de execução pela insolvência do devedor, cit., p. 303.

${ }^{317}$ Cf. LOUREIRO, Francisco Eduardo. In: PELUSO, Cezar (Coord.). Código Civil comentado. 3. ed. São Paulo: Manole, 2009. p. 1.158.

${ }^{318}$ Nesse ponto, por exemplo, a instituição de uma segunda hipoteca quando está em curso execução da primeira não será capaz de frustrar a atividade executiva, não configurando fraude de execução.

${ }^{319}$ Nesse sentido, cf. Araken de Assis: "há fraude na constituição de direitos reais de garantia (penhor hipoteca, anticrese) e direitos sobre coisa alheia (art. 1.225, III a VII, do CC de 2002), a exemplo do usufruto e da habitação, porque outorgam privilégio aos credores beneficiados ou desvaloriazam a coisa" (ASSIS, Araken de. Comentários ao Código de Processo Civil, cit., v. 6, p. 251) e Teori Albino Zavascki: "oneração é qualquer ato que, sem importar a transmissão da propriedade, do bem, limita as faculdades do domínio, mediante a criação, em favor do terceiro, de direito real. São direitos reais dessa espécie, os do art. 1.225 do Código Civil (CC/16, art. 674), divididos entre direitos de gozo e fruição (superfície, servidões, usufruto, uso, habitação, rendas sobre imóveis), e direitos de garantia (penhor, anticrese e
} 
Em relação à hipótese do inciso II do artigo 593 do CPC, o ato de alienação ou oneração também deve ser analisado em relação à sua posição na cadeia de atos praticados pelo devedor para gerar sua insolvência.

A análise é voltada para o passado e deve ser feita em ordem regressiva, ou anticronológica, dos atos mais recentes para os mais remotos, em busca daquele que causou a frustração da atividade executiva. O objetivo é exatamente verificar se o ato que se quer reconhecer como realizado em fraude de execução era apto, no momento em que foi praticado, a causar ou agravar a frustração daquela atividade executiva.

Como se observa, é da conjugação da análise dessas duas primeiras variáveis que se afere a existência do elemento objetivo da fraude de execução, qual seja a aptidão do ato para frustrar a atividade executiva decorrente da ação em curso.

Sendo irrelevante o elemento subjetivo para a configuração da fraude de execução na hipótese do inciso I do artigo 593 do CPC - como demonstramos nesta tese -, presente o elemento objetivo, o bem já poderá ser alcançado pela atividade executiva, não sendo necessária qualquer investigação sobre a má-fé do terceiro.

\section{3- Bem sujeito a registro público ou não}

Em relação ao bens objeto dos atos que podem ser praticados em fraude de execução, a análise que deve ser feita é apenas no sentido de verificar se são bens sujeitos ou não a registro público. Lembre-se aqui que não são apenas imóveis os bens sujeitos a registro público, mas também veículos automotores, embarcações, participações e direitos societários etc.

O fato de serem sujeitos a registro público permite que o terceiro possa ter conhecimento tanto da pendência da ação, por meio da inscrição de atos processuais

\footnotetext{
hipoteca). A promessa de compra e venda, agora expressamente arrolada como direito real (CC, art. 1.225, VII), já era considerada no regime anterior como apta a gerar, preenchidos certos requisitos, direito real oponível erga omnes. É direito real sui generis, que limita as faculdades do domínio relativamente ao bem comprometido, atribuindo ao comprador o poder de reivindicar a propriedade. Nessas condições, é negócio jurídico enquadrável no caput do art. 593 do CPC." (ZAVASCKI, Teori Albino. Comentários ao Código de Processo Civil, cit., v. 8, p. 267-268).
} 
como a hipoteca judiciária, a penhora ou a distribuição da execução (arts. 466, 615-A e $\left.659, \S 4^{\mathrm{o}}, \mathrm{CPC}\right)$, quanto da cadeia dos antecessores do alienante.

Essa variável, conjuntamente com as próximas duas, permitirá delimitar os casos em que o elemento subjetivo deve ser investigado e a forma pela qual essa investigação deve ser feita.

\section{4- Momento processual da prática do ato: registro possível ou não}

A análise do momento processual em que o ato de alienação é praticado também diz respeito à existência de atos processuais passíveis de registros.

Conforme demonstramos acima, a fraude de execução pode se verificar desde o ajuizamento da ação.

No entanto, diferentemente da hipótese do inciso I do artigo 593, CPC, em que a própria citação da ação fundada em direito real pode ser registrada no cartório imobiliário (cf. art. 167, I, 21, da Lei n. ${ }^{\circ}$ 6.015/1973), para a hipótese da fraude de execução prevista no inciso II desse mesmo artigo, apenas podem ser registrados os atos processuais relativos à hipoteca judiciária, penhora ou distribuição da execução (arts. 466, 615-A e 659, § $\left.4^{\circ}, \mathrm{CPC}\right)$.

Assim, imaginando-se o caso de uma ação que dê ensejo à execução de título judicial, durante a maior parte do processo não será possível ao credor registrar qualquer ato desse processo no cartório imobiliário. O primeiro ato que poderia registrar seria a hipoteca judicial e isso somente nos casos de bens imóveis.

A análise dessa variável, mostra que durante boa parte do processo, a inscrição de algum ato processual no registro público é impossível para o credor.

Sendo possível o registro, isto é, sendo o bem sujeito a registro público e já havendo ato processual passível de ser registrado, o credor tem o ônus de realizá-lo. Conforme verificamos nesta tese, essa foi a interpretação que prevaleceu quanto à 
"obrigatoriedade" prevista no artigo 169 da Lei n. ${ }^{\circ}$ 6.015/1973, principalmente à luz das diversas reformas do artigo $659, \S 4^{\circ}$, do CPC, em relação ao registro da penhora. ${ }^{320}$

Registrado o ato, por força da presunção absoluta de conhecimento por terceiro que o registro público gera - previsto, expressamente, no art. $659, \S 4^{\circ}$, do CPC, mas igualmente interpretado para os outros dois atos -, o elemento subjetivo passa a ser irrelevante para a configuração da fraude de execução, nesse caso.

Não registrado, deve ser investigada a presença do elemento subjetivo que, como vimos, consiste na má-fé do terceiro, decorrente da existência de razão para que esse pudesse saber da pendência daquela ação. ${ }^{321}$

\section{5- Terceiro imediato ou mediato}

Por fim, a quinta variável a ser considerada na análise diz respeito à pessoa que sofrerá os efeitos do reconhecimento da fraude de execução, ou seja, o terceiro. Quanto a este, deve-se distinguir se contratou diretamente com devedor (terceiro imediato) ou se contratou já com outro terceiro (terceiro mediato).

Tendo sido revogada, com o advento do CC, a norma do artigo 824 do Código Civil anterior - que, como visto, previa que o direito de prosseguir a execução contra terceiros mediatos dependida do registro da hipoteca judiciária -, não há que questionar que também esses podem ter seus bens alcançados em seu patrimônio em razão da fraude de execução.

\footnotetext{
${ }^{320}$ Já evocando essa ideia com base no artigo 240 da Lei n. ${ }^{\circ} 6.015 / 1973$, cf. Milton Flaks: "não se pode admitir que a lei tivesse a ingenuidade de supor que os credores, por simples amor ao próximo, promovessem o registro, arcando com os ônus financeiros, apenas para resguardar possível boa-fé de terceiros desconhecidos. Exatamente para impedir que terceiro adquirente do bem penhorado possa subtraílo à constrição judicial, provando a sua boa-fé e que, na data do ato de disposição, o devedor possuía meios de satisfazer o crédito, é que a lei concede ao credor a faculdade (...) de promover o registro, quando se tratar de imóvel" (FLAKS, Milton. Fraude de execução e fraude contra a fazenda. Revista Brasileira de Direito Processual, v. 34, p. 74, jul./ago. 1982).

${ }^{321}$ Fica bem evidente, aqui, a caracterização do registro como ônus. É interesse do próprio credor fazer o registro, pois se o fizer, estará resguardado de qualquer discussão sobre o elemento subjetivo. Estando presente o elemento objetivo e feito o registro, a fraude de execução já estará configurada independentemente de o terceiro estar, na realidade, de boa ou má-fé. Não a tendo feito, sujeitar-se-á a essa discussão que poderá ocorrer no próprio processo de execução ou na ação autônoma de embargos de terceiro.
} 
A distinção entre tratar-se de terceiro mediato ou imediato, contudo, tem relevância na investigação quanto à presença do elemento subjetivo, como será visto no próximo item, conjugando tal variável com as descritas nos dois itens anteriores.

\section{6- Delimitação dos casos em que o elemento subjetivo é relevante e sugestão de critério - extraído do ordenamento jurídico - para aferir sua presença}

Partindo da análise feita nos cinco itens precedentes, delimitamos a hipótese na qual é necessária a investigação da presença do elemento subjetivo: a prevista no inciso II do artigo 593 do CPC e em que não haja notícia da ação nos registros públicos em razão da inscrição da hipoteca judiciária, da penhora ou da distribuição da execução.

Esse caso pode ocorrer em diversas situações: (i) o bem alienado não é sujeito a registro público; (ii) o momento processual em que a alienação foi feita ainda não permitia a inscrição de nenhum ato advindo daquele processo no registro público; (iii) o credor já poderia fazer o registro, mas algum motivo alheio o impediu (v.g. necessidade de retificação da área no registro); ou (iv) simplesmente porque o credor não quis.

Não importa o motivo: não podendo, ou não querendo fazer o registro, a consequência para o credor é clara: não se beneficiará da presunção absoluta que excluiria a relevância do elemento subjetivo para a configuração da fraude de execução.

Nesse caso - e só nesse caso - a existência de má-fé do terceiro deverá ser investigada. Tal investigação, contudo, deve levar em conta a má-fé, como decorrente da existência de razão para que esse terceiro soubesse da ação pendente, exigindo dele, na consecução do negócio, que atue com diligência, pautando-se pelo pricípio da boa-fé (art. $422, \mathrm{CC})$.

Aqui alcança-se a tormentosa questão antes anunciada: qual o conteúdo da diligência que se espera do terceiro para que não seja considerado de má-fé?

Frente a essa questão, esquivam-se os autores e a jurisprudência, valendo-se de expressões as mais vagas. Dizem que o terceiro deve agir com a diligência 
razoável, a do bom pai de família, a do homem médio, a "do homem médio e não do neurótico ${ }^{\prime 322}$ ou outros termos similares que também não trazem segurança na aplicação da lei às situações concretas.

Basicamente as perguntas às quais se deve responder são: (i) deve o terceiro satisfazer-se com as certidões fornecidas pelos cartórios de registros públicos ou deve fazer pesquisa nos distribuidores forenses? (ii) Entendendo pela necessidade de consulta aos distribuidores forenses, em quais deles deve tal busca ser feita, em todas as comarcas do Brasil e no âmbito das Justiças Estadual, Federal, Trabalhista, Eleitoral e Militar? Deve-se pesquisar também os antecessores do alienante ou só este? Qual o período que a pesquisa deve abranger?

Identificadas, nesta tese, em que constitui a má-fé do terceiro e a hipótese em teria relevância para a configuração da fraude de execução, já se tem um ponto de partida para buscar, no ordenamento jurídico, critério para responder a essas perguntas.

A primeira resposta - quase intuitiva em razão do exposto acima - é que a diligência do terceiro não se pode limitar à análise da certidão do cartório de registro público em que esteja registrado o bem.

Em primeiro lugar porque essa diligência seria necessariamente parcial. Além de se aplicar apenas para bens sujeitos a registro, o que já deixaria sem regra boa parte das situações de fraude de execução, ${ }^{323}$ em diversos casos a informação da pendência da ação não constará das certidões de registros públicos, seja porque no processo ainda não

\footnotetext{
${ }^{322}$ TRT $15^{\mathrm{a}}$ Região, $3^{\mathrm{a}}$ T., AC. 007497/2001, rel. Des. Samuel Hugo Lima, j. 05.03.01.

${ }^{323}$ Nesse sentido, a observação de Leonardo Greco: "há um novo ambiente sociológico. Ser devedor não é mais uma vergonha e não pagar os débitos não é mais um sinal de desonra. (...) Há também um novo ambiente econômico. O patrimônio das pessoas não é mais essencialmente imobiliário. Houve uma extraordinária diversificação dos bens e dos tipos de investimentos possíveis, o que aumentou a dificuldade de conhecê-los." (GRECO, Leonardo. Em busca da efetividade do processo de execução. Comunicações: Caderno do Programa de Pós-Graduação em Direito da Unimep, Piracicaba, ano 3, n. 1, p. 156, ago. 1998). Tal alteração patrimonial também já foi sentida pela jurisprudência: "não se pode perder de vista que os bens não sujeitos a registro podem ter um elevado valor de mercado. E o caso por exemplo, das jóias e das obras de arte, de valor muitas vezes superior a imóveis de bom padrão" (TJSP, 10ª Câm. de Dir. Priv., AI 207.327-4, rel. Des. Ruy Camilo, j. 12.06.01). Além das jóias e obras de arte, mencionadas nesse acórdão, pode-se pensar, ainda, na vasta classe das máquinas e equipamentos, em safras colhidas, lotes de mercadorias, títulos de crédito etc.
} 
atingiu a fase dos atos processuais sujeitos a registro, seja por haver algum óbice para o registro, seja porque, sendo faculdade sua, o credor entendeu melhor não fazê-lo.

Em segundo lugar, a diligência do terceiro não deve se limitar à certidão do cartório de registros públicos porque a Lei n. ${ }^{\circ} 7.433 / 1985$ indica, em seu artigo $1^{\circ}, \S 2^{\circ}$, a necessidade de se pesquisar sobre "feitos pendentes" tendo prevalecido o entendimento jurisprudencial de que essa pesquisa deve se dar nos distribuidores forenses. ${ }^{324}$

Em terceiro lugar, limitar a busca aos registros públicos desconsidera a realidade do país, em que grande parte da população sequer vai aos cartórios para registrar o instrumento de aquisição do bem, ${ }^{325}$ não sendo de se esperar que tenha mais diligência quanto ao registro de um ato processual.

No tocante à segunda pergunta: em quais distribuidores a busca deve se concentrar, também a lei fornece o critério a ser utilizado: dispondo o artigo 593, II, do CPC que a fraude de execução estaria configurada quando pendesse "contra o devedor demanda capaz de reduzi-lo à insolvência" - ação, em regra, fundada em direito pessoal, sua competência, também em regra, deve ser a do foro do domicílio do réu, pessoa física, ou da sede ou sucursal da pessoa jurídica, tal como previsto nos artigos 94 e 100, IV, "a" e "b", do CPC.

\footnotetext{
${ }^{324} \mathrm{Cf}$. os acórdãos citados no item 4.4 e também o pronunciamento da Corregedoria Geral da Justiça no Processo CG n ${ }^{\circ}$ 204/2007, citado na nota 260. Ademais, a obtenção de certidões dos distribuidores forenses já é costume arraigado na sociedade brasileira, como indica Philadelpho Azevedo (cf. Da fraude contra sentenças, cit., p. 28-29). Houve grande preocupação do legislador processual desde a decada de $1930 \mathrm{em}$ melhorar as pesquisas nos distribuidores, de modo que ainda hoje esses são fonte relevante de informações quando da aquisição de um bem, como atesta Paulo Henrique dos Santos Lucon: "com a distribuição da demanda, poderão terceiros obter certidões junto aos distribuidores do domicílio do devedor. Mais do que uma garantia para as partes litigantes, a demanda regularmente proposta, indicando os nomes corretos, é um elemento de proteção para terceiros. É praxe, principalmente nas grandes cidades, em toda a negociação cercada de cuidados, exigir-se do alienante certidões negativas, principalmente dos distribuidores cíveis." (LUCON, Paulo Henrique dos Santos. Fraude à execução, responsabilidade processual civil e registro da penhora, cit., p. 138).

${ }^{325}$ Nesse sentido, cf. trecho do voto do Min. Athos Gusmão Carneiro em um dos precedentes da súmula 84 do Superior Tribunal de Justiça, que permite a oposição de embargos de terceiro com base em compromisso de compra e venda, ainda que este não esteja registrado: "no nosso país, principalmente nas camadas pobres da população, um grande número de negócios, e até direi, a maior parte dos negócios, é efetuada de maneira menos formal, e até absolutamente informal. Compram-se e vendem-se pequenos terrenos, apartamentos e casas apenas mediante a emissão de recibos, sinais de arras e mesmo de promessas de compra-e-venda ou 'transferências de posse' redigidos de forma singela. E é muitíssimo comum que esses documentos não venham a ser registrados no Registro de Imóveis, inclusive porque com frequencia os termos em que estão vazados não permitiriam o registro." (STJ, $4^{\mathrm{a}}$ T., REsp. 1.172/SP, rel. Min. Athos Carneiro, j. 16.04.90).
} 
Já no que diz respeito aos órgãos do Poder Judiciário, a diligência deverá se limitar, ordinariamente, à busca nos distribuidores das Justiças Estadual, Federal e Trabalhista. Somente se o alienante for, sabidamente, militar ou político, é que a busca deverá envolver também as Justiças Eleitoral e Militar.

Quanto à terceira pergunta, cabe distinguir se o bem é ou não sujeito a registro. Sendo sujeito a registro público, nele o terceiro poderá colher as informações referentes aos antecessores do alienante e, com base nessas informações - em especial seus nomes e endereços da época em que alienaram o bem -, poderá, igualmente, proceder a busca nos distribuidores forenses desses locais, verificando se na data da alienação do bem pendia contra tais antecessores demanda que pudesse configurar aquela alienação como realizada em fraude de execução. ${ }^{326}$

Não sendo bem sujeito a registro, o terceiro não tem, em princípio, razão para saber dos antecessores do alienante, de modo que sua diligência limitar-se-á apenas em relação à busca de ações pendentes em face do próprio alienante.

Por fim, em relação ao período de tempo que a busca deve envolver, a localização da resposta no ordenamento jurídico se complica, uma vez que a eficácia da decisão que reconhece a fraude de execução é declaratória, não estando sujeita à prescrição. ${ }^{327}$ Desse modo, ainda que a alienação tenha ocorrido há trinta anos, poderia ser declarada como realizada em fraude de execução atualmente.

O que se sujeita à prescrição é a pretensão objeto da ação pendente. Uma vez prescrita essa, não há interesse processual em ser reconhecida a fraude. ${ }^{328}$ Atualmente,

\footnotetext{
${ }^{326}$ Especificamente em relação aos bens imóveis, diz Mollica: "para comprovar sua boa-fé, não basta que o adquirente do bem obtenha os documentos acima indicados apenas em nome do vendedor do imóvel. Se assim fosse, a qualquer devedor bastaria conferir o imóvel a uma pessoa jurídica ou alienar o imóvel a um amigo, que não tivesse qualquer tipo de restrição em suas certidões, para que o adquirente, solicitando as certidões apenas do vendedor, pudesse alegar a boa-fé, em total prejuízo dos credores." (MOLLICA, Luciano. Novos contornos para a fraude de execução na alienação de bem imóvel, sob a perspectiva de dinamizar os negócios imobiliários, cit., p. 98).

${ }^{327}$ Sobre o tema da imprescritibilidade das pretensões declaratórias, cf. o clássico artigo de Agnelo Amorim Filho, Critério científico para distinguir a prescrição da decadência e para identificar as ações imprescritíveis. Revista de Direito Processual Civil, v. 3, P. 95-132, jan./jun. 1961. Também essa parece ser a posição de Pedro Belmiro Welter (Fraude de execução, cit., p. 97).

${ }^{328}$ Nesse sentido, José Sebastião de Oliveira: "o terceiro embargante pode, ainda, arguir a prescrição do direito do credor embargado que, sendo direito oriundo de execução de título judicial, prescreve em vinte
} 
depois que a Lei n. ${ }^{\circ}$ 11.280/2006 tornou a prescrição matéria de ordem pública, pode esta ser suscitada também pelo terceiro, como mais um motivo para desconstituir a penhora, caso seu bem tenha sido constrito em razão da fraude de execução.

Contudo, essa prescrição - embora possível de ser suscitada até mesmo pelo terceiro, em razão da Lei n. ${ }^{\circ}$ 11.280/2006 - não nos auxilia na solução da diligência que se espera dele para que não se configure a sua má-fé. De fato, sendo necessário haver ação pendente para a caracterização da fraude de execução, essa prescrição, quando existir, já terá se verificado antes do ajuizamento da ação ou tratar-se-á de prescrição intercorrente, de difícil configuração e impossível estabelecimento de uma regra geral, dado que se contaria do último ato de cada ação em curso, em cada caso concreto.

Cientes dessa situação, os autores sugerem, segundo seus próprios critérios, quais seriam os períodos que a busca deveria abranger.

Sustentando período de vinte anos, JosÉ SEBASTIÃo DE OlIVEIRA diz que "o adquirente do imóvel, para resguardar seus direitos, tem de obter a certidão vintenária desse bem e, concomitantemente, também as certidões negativas de ações cíveis e criminais de todas as pessoas que já figuraram como titulares do domínio daquele bem, pois só assim, estaria livre de futuramente ser surpreendido co a apreensão do bem adquirido, fundada numa alienação anterior em fraude de execução. As certidões dos distribuidores hoje são tão importantes como a negativa de ônus do cartório imobiliário, principalmente considerando que uma ação de conhecimento de cunho condenatório pode arrastar-se por muitos anos" 329

Discordando do referido autor, LUCIANO MolliCA propõe período de dez anos, embora confesse não haver "resposta científica para tal proposição", dizendo ser tal prazo "razoável", uma vez que "dez anos, regra geral, é tempo mais do que suficiente para o trâmite de qualquer demanda, inclusive eventual demanda de conhecimento." ${ }^{330}$

anos (...) e de direito fundado em título de crédito, é necessário ater-se às legislações específicas" (Fraude à execução, cit., p. 109-110).

${ }^{329}$ OLIVEIRA, José Sebastião de. Fraude à execução, cit., p. 111.

${ }^{330}$ MOLLICA, Luciano. Novos contornos para a fraude de execução na alienação de bem imóvel, sob a perspectiva de dinamizar os negócios imobiliários, cit., p. 98-99. 
Embora concordemos que a declaração de inoponibilidade proveniente do reconhecimento da fraude de execução não esteja sujeita à prescrição e que as prescrições prévias ou intercorrentes das pretensões objeto das ações em curso não permitam construir um critério geral para a diligência esperada do terceiro, entendemos que, também aqui, seria possível buscar no ordenamento jurídico a resposta para a questão.

Nossa atenção se volta-se para outra forma de prescrição, que igualmente proporciona segurança na aquisição do bem: a prescrição aquisitiva, ou usucapião.

Como se sabe, a posse continuada de um bem gera para o possuidor, ainda que esteja de má-fé, a aquisição originária de sua propriedade, após o decurso do prazo previsto em lei (cf. arts. 1.238 do CC). Tal posse, por força do artigo 1.243 do CC, não precisa ser o de apenas um titular, admitindo-se o cômputo da posse dos antecessores.

Assim, o terceiro deveria pesquisar a existência de ações pendentes pelo prazo suficiente para que se verifique a prescrição aquisitiva, ${ }^{331}$ o que, considerando-se os prazos mais longos da usucapião, implica uma busca de quinze anos para os bens imóveis (art. 1.238, CC) ${ }^{332}$ e de cinco anos para os bens móveis (art. 1.261, CC).

Ocorrida a prescrição aquisitiva, portanto, o bem de terceiro - agora fruto de aquisição originária - não mais poderá ser alcançado pela atividade executiva. ${ }^{333}$

\footnotetext{
${ }^{331}$ Embora entenda que a pesquisa do terceiro deva concentrar-se na análise das informações constantes nos registros públicos, Marcelo Terra, sustenta nossa afirmação no sentido de que a busca de eventuais vícios que coloquem em risco a aquisição do bem deve se dar por prazo suficiente para que se verifique a prescrição aquisitiva: "a fé pública registral não deriva de um único assento, mas sim de todo um conjunto de inscrições, no sentido amplo de registro. (...) Em face da falibilidade humana (do registrador), a inscrição pode se achar em desacordo com o título, ocasionando a tão temida incompatibilidade entre a realidade registral e a extratabular. Entendemos, assim, a necessidade de o adquirente, para configuração de sua boa fé, proceder ao estudo dos títulos registrados, ao menos no período suficiente para a prescrição aquisitiva." (TERRA, Marcelo. A fé pública registral, cit., p. 48).

${ }^{332}$ No entanto, considerando a regra do artigo 2.028 do CC e eventuais prazos de usucapião em curso na data de sua vigência, até 11 de janeiro de 2013, as buscas deverão abranger vinte anos (prazo anterior, que ainda não teria alcançado sua metade até 11.01.2003), somente após poderão ser de quinze anos. Dependendo do imóvel e da situação, esses prazos podem ainda diminuir, conforme os artigos 1.038 e seguintes do CC.

${ }^{333}$ Embora bastante rara, essa situação já foi apreciada pela jurisprudência:

"Embargos de terceiro - penhora de imóvel - Alegação de usucapião pelos embargantes - Admissibilidade Posse por tempo suficiente (...) Se é possível alegar usucapião em defesa de ação reivindicatória, nada impede a sua utilização em embargos de terceiro, comprovando deste modo, os embargantes, a posse sobre o bem contritado e a própria aquisição do domínio pela prescrição aquisitiva ( $2^{\circ}$ TAC-SP, $2^{\text {a }}$ Câm., Apel.
} 
Pela nossa análise, portanto, a diligência que o ordenamento jurídico impõe ao terceiro para verificar se há ação pendente que possa comprometer a aquisição do bem em razão da fraude de execução seria: a busca nos cartórios distribuidores do foro de domicílio do devedor, pessoa física, ou da sede ou sucursal da pessoa jurídica - e, no caso de bens registráveis, também de seus antecessores - pelo prazo suficiente para que se verifique a prescrição aquisitiva do bem objeto do contrato, sendo em regra, de quinze anos para bens imóveis e cinco anos para bens móveis. ${ }^{334}$

Não agindo com tal diligência, estará configurada a sua má-fé. No entanto, não é esse o único meio de configurá-la. É possível que, mesmo que a ação esteja pendente em foro diverso do domicílio do devedor, haja razão para que o terceiro saiba desse fato.

Essa razão - que não será a diligência esperada acima - pode ser demonstrada na execução, sendo aqui muito importante as presunções clássicas de fraude, como a alienação entre parentes ou amigos, o preço vil pago pelo terceiro, a permanência do devedor na posse do bem e outras extraídas das regras de experiência (art. 335, CPC).

Tais fatos atuam no convencimento do julgador por força de presunção simples (ou hominis), uma vez que dificilmente se terá uma prova cabal da má-fé do terceiro como no caso do Resp 555.044-DF, em que o reconhecimento da fraude de execução baseou-se em prova documental por escritura pública e depoimento de testemunha quanto ao conhecimento da pendência da ação pelos terceiros. ${ }^{335}$

181.735-3, rel. Juiz Egas Galbiatti, j. 14.08.85, in Jurisprudência Brasileira, vol. 175, Curitiba: Juruá, 1995, p. 239/240).

${ }^{334}$ Não quer isso dizer, contudo, que esses sejam os únicos documentos a serem verificados na aquisição de um bem. São os que configuram a diligência exigida do terceiro para que não esteja, de plano configurada a sua má-fé em relação a essa hipótese de fraude de execução. Para a hipótese do artigo 593, III, c/c o art. 185 do CTN, outros serão exigidos, como a certidões negativas de débitos fiscais. No entanto, por uma opção metodológica da exposição (cf. ressalva feita no item 2.4), não é essa a hipótese de que estamos tratando.

${ }^{335}$ Barbosa Moreira, ilustra bem a situação: "o órgão judicial, para formar sua convicção e julgar a causa, precisa esclarecer-se acerca dos fatos relevantes, e essa, como ninguém ignora é a função das provas. Pode acontecer, no entanto - e o caso não é raro -, que, com referência a determinado fato, decisivo para a solução do litígio, a atividade instrutória se revele incapaz de ministrar, diretamente, elementos bastantes de convicção; e, por outro lado, venha aos autos material probatório suficiente para que o juiz se convença de ter ocorrido fato diverso, mas relacionado com aquele que constituía o thema probandum. A relação entre os dois fatos - o conhecido e o desconhecido - é tal, suponhamos, que da existência do primeiro se possa logicamente inferir, senão com absoluta certeza, ao menos com forte dose de probabilidade, a 
Fecha-se assim, a exposição da metodologia sugerida para a análise da configuração das hipóteses de fraude de execução dos artigos 593, I e II, do CPC.

Em primeiro lugar, deve-se analisar a presença do elemento objetivo, ou seja, se o ato praticado frustrou ou não a atividade executiva (não era o bem litigioso ou não reduziu à insolvência). Em caso positivo, a fraude de execução estará configurada na hipótese do inciso I e deve prosseguir na hipótese do inciso II.

Num segundo momento - e somente na hipótese do inciso II -, deve-se analisar se o bem que foi alienado era sujeito a registro público e se nele estava inscrita notícia da pendência da ação. Nesse caso, por força da presunção absoluta, o elemento subjetivo é irrelevante e a fraude de execução estará configurada.

Não havendo o registro, deve-se investigar a presença da má-fé do terceiro, demonstrando-se que havia razão para que ele soubesse da existência da ação, seja porque não agiu com a diligência esperada - tal com descrita acima -, seja por outra razão. 


\section{8- O FUTURO DA FRAUDE DE EXECUÇÃO}

Embora consideremos que a hipótese interpretativa apresentada nesta tese e a metodologia nela baseada sejam aptas a fornecer maior segurança na aferição da relevância do elemento subjetivo para a configuração das hipóteses de fraude de execução, não se pode negar que a matéria comporta - e até clama - por melhor tratamento legal.

Tal afirmação baseia-se não apenas no crescente descompasso entre a legislação processual e a de direitos públicos a partir de $1939,{ }^{336}$ mas também na indesejável fragmentação da disciplina do instituto em diversos diplomas legislativos, que somente dificultam sua aplicação, ${ }^{337}$ dando causa aos diversos entendimentos existentes sobre o tema.

Assim, tendo ciência de projetos de lei que propõem alterações na disciplina da fraude de execução, dedicamos o presente capítulo a analisar os rumos que neles estão sendo propostos, fazendo em seguida as sugestões que nos parecem pertinentes.

\section{1- Alterações previstas em legislação projetada: suas vantagens e desvantagens}

Atualmente, há dois projetos relacionados ao tema tratado nesta tese em trâmite na Câmara dos Deputados. O primeiro deles é o Projeto de Lei n. ${ }^{\circ}$ 3.057, de 2000, que dispõe sobre matérias relacionadas ao parcelamento do solo urbano, já tendo sofrido diversas emendas e alterações. ${ }^{338}$ O segundo é o Projeto de Lei n. ${ }^{\circ} 5.159$, de 2009 , oriundo de anteprojeto sugerido pela Associação Brasileira das Entidades de Crédito Imobiliário e Poupança - ABECIP, Câmara Brasileira da Indústria da Construção - CBIB, Instituto de Registro Imobiliário do Brasil - IRIB e Sindicato das Empresas de Compra, Venda,

\footnotetext{
${ }^{336}$ Tal como exposto nos itens 4.3 e 4.4 e ilustrado graficamente na Figura 2 do Apêndice 3 desta tese.

${ }^{337}$ É o que observa Alcides de Mendonça Lima, ele mesmo vítima do engano causado pela não repetição da norma do artigo 281 do Decreto n. ${ }^{\circ} 4.857 / 1939$ pela Lei n. ${ }^{\circ}$ 6.015/1973 mencionado nos itens 4.4 e 5.1 desta tese: "o Código, aliás, ao tratar da 'fraude de execução' [refere-se aqui à hipótese do artigo 593, I, do $\mathrm{CPC}$ ] deveria referir-se à exigência da inscrição, porque, pela redação já tradicional, a impressão que se dá é que basta a propositura da ação, como única prova que o credor deverá fazer, para tornar ineficaz o ato entre o devedor e o terceiro. Somente o Regulamento dos Registros Públicos é que menciona a formalidade. O intérprete menos avisado, porém, poderá ater-se aos termos apenas do Código, cuja omissão é injustificável." (LIMA, Alcides de Mendonça. Comentários ao Código de Processo Civil, cit., v. 6, t. 2, p. 570 - sem colchetes no original).
} 
Locação e Administração de Imóveis Residenciais e Comerciais de São Paulo - SECOVI, que foi discutido no Primeiro Encontro de Jovens Processualistas, realizado em São Paulo em dezembro de 2008, pelo Instituto Brasileiro de Direito Processual - IBDP.

No que diz respeito ao tema objeto desta tese, ambos os projetos sugerem alterações praticamente idênticas nos artigos 167 e 172 da Lei n. ${ }^{\circ}$ 6.015/1973, como se observa no quadro abaixo:

\begin{tabular}{|c|c|}
\hline PL n. ${ }^{\circ} 3.057 / 2000$ & PL n. ${ }^{\circ} 5.159 / 2009$ \\
\hline $\begin{array}{l}\text { "Art. 167. No Registro de Imóveis, além da } \\
\text { matrícula, será feito o registro de: (...) } \\
\S 1^{\circ} \text { Será objeto de averbação: } \\
\text { I - a penhora, o arresto ou o sequestro; } \\
\text { II - medida judicial acautelatória ou medida } \\
\text { administrativa prevista em lei; (...) } \\
\text { V - a notícia de ajuizamento de ação real, } \\
\text { pessoal reipersecutória ou condenatória, cujos } \\
\text { resultados ou responsabilidade patrimonial } \\
\text { possam interferir em direitos registrados, após } \\
\text { a citação, bem assim do ajuizamento de ação } \\
\text { de execução, podendo os interessados requerer } \\
\text { ao juiz da causa o seu cancelamento nos casos } \\
\text { de excesso, descabimento, substituição por } \\
\text { outro imóvel ou prestação de caução, e, sendo } \\
\text { o caso, o reconhecimento de litigância de má- } \\
\text { fé; } \\
\text { VI - a inscrição de débito, em nome do titular } \\
\text { do direito real registrado, como dívida ativa da } \\
\text { União, dos Estados, do Distrito Federal, dos } \\
\text { Municípios ou das respectivas autarquias, } \\
\text { mediante requerimento da autoridade } \\
\text { competente; (...) } \\
\S 4^{\circ} \text { Perdem eficácia os atos previstos nos } \\
\text { inciso II, V e VI do § } 1^{\circ} \text { deste artigo, se, no } \\
\text { prazo de } 60 \text { (sessenta) meses a contar da sua } \\
\text { efetivação, não for requerida ou determinada, } \\
\text { conforme o caso, sua prorrogação." } \\
\text { (...) }\end{array}$ & $\begin{array}{l}\text { "Art. 167. No Registro de Imóveis, além da } \\
\text { matrícula, será feito o registro de: (...) } \\
\S 1^{\circ} \text { Será objeto de averbação: (...) } \\
\text { VII - a penhora, o arresto ou o sequiestro; } \\
\text { VIII- a medida judicial acautelatória, o } \\
\text { arrolamento fiscal, ou a medida administrativa } \\
\text { acautelatória prevista em lei; } \\
\text { IX - a notícia de ajuizamento de ação real, } \\
\text { pessoal reipersecutória ou de outro tipo de } \\
\text { ação, cujos resultados ou responsabilidade } \\
\text { patrimonial possam interferir em direitos } \\
\text { registrados, bem assim do ajuizamento de ação } \\
\text { de execução, podendo o interessado requerer } \\
\text { ao juiz da causa o seu cancelamento nos casos } \\
\text { de excesso, descabimento, substituição por } \\
\text { outro imóvel ou prestação de caução, e, sendo } \\
\text { o caso, o reconhecimento de litigância de má } \\
\text { fé; } \\
\text { (...) } \\
\S 8^{\circ} \text { A notificação, a interpelação o protesto } \\
\text { contra alienação de bens, de que trata os arts. } \\
867 \text { a } 873 \text {, da Lei no } 5.869 \text {, de } 11 \text { de janeiro de } \\
1973 \text { (Código de Processo Civil), bem assim } \\
\text { quaisquer outros procedimentos judiciais que } \\
\text { não admitam o contraditório, não poderão ser } \\
\text { inferiores ao valor do imóvel que foi objeto da } \\
\text { mesma; } \\
\text { (...) } \\
\S 11 \text { A notícia de ajuizamento de ações, nas } \\
\text { comarcas onde houver o serviço de registro de } \\
\text { Distribuição, será realizada mediante certidão } \\
\text { de feitos ajuizados expedida por este." }\end{array}$ \\
\hline $\begin{array}{l}\text { "Art. 172. No Registro de Imóveis, serão feitos } \\
\text { os registros e averbações de todos os títulos e }\end{array}$ & $\begin{array}{l}\text { "Art. 172. No Registro de Imóveis, serão feitos } \\
\text { os registros e averbações de todos os títulos e }\end{array}$ \\
\hline
\end{tabular}

${ }^{338} \mathrm{O}$ texto citado nesta tese é o do segundo substitutivo, publicado no Diário da Câmara dos Deputados de 20 de fevereiro de 2008, Suplemento n. ${ }^{\circ}$ 14, p. 02. Configurando-se, até 21 de dezembro de 2009, a versão atual do referido projeto de lei (cf. consulta, nessa data, no sítio eletrônico <www.camara.gov.br>). 


\begin{tabular}{|c|c|}
\hline $\begin{array}{l}\text { atos inter vivos ou mortis causa, para } \\
\text { constituição, transmissão ou extinção de } \\
\text { direitos, para a sua disponibilidade ou sua } \\
\text { validade em relação a terceiros, bem assim de } \\
\text { fatos aos quais se deva dar publicidade, nos } \\
\text { termos desta Lei. (...) } \\
\S 6^{\circ} \text { Ressalvado o disposto nos arts. } 129 \text { e } 130 \\
\text { da Lei n } 11.101 \text {, de } 9 \text { de fevereiro de } 2005 \text {, } \\
\text { não poderão ser opostos, ao terceiro de boa-fé } \\
\text { que tiver adquirido imóvel a título oneroso, } \\
\text { fatos ou situações jurídicas não constantes da } \\
\text { matrícula. } \\
\S 7^{\circ} \text { Uma vez procedidas às averbações de que } \\
\text { tratam os incisos V e VI do } \S 1^{\circ} \text { do art. } 167 \text {, } \\
\text { para os fins previstos nos arts. } 472 \text { e } 593 \text { do } \\
\text { Código de Processo Civil, os posteriores } \\
\text { adquirentes não serão considerados terceiros } \\
\text { de boa fé. } \\
\S 8^{\circ} \text { A averbação da existência de ações reais } \\
\text { ou pessoais reipersecutórias, que tenham como } \\
\text { objeto direitos registrados, torna absoluta, para } \\
\text { os efeitos do art. } 219 \text { do Código de Processo } \\
\text { Civil, a presunção de conhecimento por }\end{array}$ & $\begin{array}{l}\text { atos inter vivos ou mortis causa, para } \\
\text { constituição, transmissão ou extinção de } \\
\text { direitos, para a sua disponibilidade ou sua } \\
\text { validade em relação a terceiros. } \\
(\ldots) \\
\S 5^{\circ} \text { Ressalvado o disposto nos arts. } 120 \\
{[\text { rectius: } 129] \text { e } 130 \text {, da Lei n }{ }^{\circ} 11.101 \text {, de } 09 \text { de }} \\
\text { fevereiro de } 2005 \text {, não poderão ser opostos ao } \\
\text { terceiro de boa-fé que tiver adquirido direitos } \\
\text { reais sobre o imóvel a título oneroso, fatos ou } \\
\text { situações jurídicas não constantes da matrícula. } \\
\S 6^{\circ} \text { Uma vez procedidas as averbações de que } \\
\text { tratam os incisos V e VI [rectius: IX e X] do } \S \\
1^{\circ} \text { do art. } 167 \text {, para os fins previstos nos arts. } \\
472 \text { e } 593 \text { do Código de Processo Civil, os } \\
\text { posteriores adquirentes não serão considerados } \\
\text { terceiros de boa fé. } \\
\S 7^{\circ} \text { A averbação da existência de ações reais } \\
\text { ou pessoais reipersecutórias, que tenham como } \\
\text { objeto direitos registrados, torna absoluta, para } \\
\text { os efeitos do art. } 219 \text { do Código de Processo } \\
\text { Civil, a presunção de conhecimento por } \\
\text { terceiros da litigiosidade da coisa." }\end{array}$ \\
\hline
\end{tabular}

A tendência dessas propostas, como se observa, é a ampliação da possibilidade de utilização do registro público para dar notícia da pendência da ação, permitindo que tal se faça desde o início da ação seja ela real, pessoal reipersecutória ou condenatória, possibilitando conhecimento por terceiros.

Na linha dos artigos 659, § $4^{\circ}$, depois da Lei n..$^{\circ}$ 10.444/2001, e 615-A, ambos do CPC, permite-se a averbação da notícia da pendência da ação no registro imobiliário sem que tal averbação configure requisito da fraude de execução, como ocorria nos artigos 950, I, e 969, III, dos códigos processuais de São Paulo e do Distrito Federal, respectivamente. ${ }^{339} \mathrm{O}$ efeito da averbação, como prevê o artigo 167 projetado é apenas para dar publicidade ao ato, eliminando a boa-fé do terceiro. A redação dos parágrafos desse dispositivo, contudo, poderia se mais clara, como a do atual $\S 4^{\circ}$ do artigo 659 do Código de Processo Civil.

\footnotetext{
${ }^{339}$ Também era essa a intenção original do PL n. ${ }^{\text {3 }} 3.057 / 2000$, como se vê na redação que dava ao $\S 9^{\circ}$ ao art. 172: "o reconhecimento da ineficácia da alienação ou oneração por fraude à execução depende de prévio registro do ajuizamento da ação nos termos do art. 167, XI" (cf. <www.camara.gov.br>).
} 
Comentando essas alterações quando constavam do PL n. ${ }^{\circ} 20 / 2007,{ }^{340}$ LuCIANO MolliCA afirma que "a possibilidade de que todo e qualquer autor de uma ação de conhecimento, mesmo antes que se tenha o mínimo de certeza quanto ao direito demandado, possa averbar a existência de sua demanda na certidão de matrícula de imóveis de propriedade do réu deve ser vista com ressalvas. Trata-se de instrumento perigoso, se utilizado maliciosamente pelo autores, podendo causar sérios prejuízos ao demandado, na medida em que, sob o ponto de vista prático, poderá implicar em um completo congelamento do patrimônio do demandado durante o moroso trâmite de um processo, no qual, ainda nem sequer haverá uma sentença de primeiro grau favorável ao autor." 341

Não nos parece, que, nesse ponto, as propostas legislativas mereçam crítica, uma vez que a situação projetada é mais segura que a atual, em que se permite, a averbação de protesto contra alienação de bens, ${ }^{342}$ que nada mais é do que mera notificação judicial em que não há exercício do contraditório e os autos sequer ficam em cartório para consulta ao público, por força do artigo 872 do Código de Processo Civil.

A crítica que fazemos, nesse ponto, é em relação ao $\S 8^{\circ}$ do artigo 167 projetado pelo PL n. ${ }^{o}$ 5.159/2009, um vez que ainda mantém a possibilidade de averbação

\footnotetext{
${ }^{340}$ O PL n. ${ }^{\circ}$ 20/2007 foi apensado ao PL n. ${ }^{\text {3 } 3.057 / 2000, ~ c o n f o r m e ~ d e c i s a ̃ o ~ d a ~ M e s a ~ D i r e t o r a ~ d a ~ C a ̂ m a r a ~ d o s ~}$ Deputados publicada no Diário da Câmara dos Deputados de 26 de junho de 2007, p. 31.668, col. 2, ao deferir o requerimento n. ${ }^{\circ}$ 1161/07 da Deputada Maria do Carmo Lara (cf. www.camara.gov.br). O teor dos dispositivos aqui tratados e os constantes no PL n. ${ }^{\circ}$ 20/2007 é, no entanto, praticamente idêntico.

${ }^{341}$ MOLLICA, Luciano. Novos contornos para a fraude de execução na alienação de bem imóvel, sob a perspectiva de dinamizar os negócios imobiliários, cit., p. 207.

${ }^{342}$ Nesse sentido, o entendimento já pacífico do Superior Tribunal de Justiça: "O poder geral de cautela do juiz, disciplinado no art. 798 do CPC, é supedâneo para permitir a averbação, no registro de imóveis, do protesto de alienação de bens, e se justifica pela necessidade de dar conhecimento do protesto a terceiros, servindo, desse modo, como advertência a pretendentes à aquisição dos imóveis do possível devedor, resguardando, portanto, os interesses de eventuais adquirentes e do próprio credor. Precedente da Corte Especial." (STJ, 3 ${ }^{\mathrm{a}}$ T., REsp. 695.095/PR , rel. Min. Nancy Andrighi, j. 26.10.06. Também 4 T., RMS 28.290/RN, rel. Min. João Otávio de Noronha, j. 05.05.09. No Estado de São Paulo, tal entendimento encontra-se até mesmo positivado pelo Provimento n. ${ }^{\circ}$ 20/2007 da Corregedoria Geral da Justiça, publicado no DJE de 18.07.2007, que assim dispõe: "Considerando a recente publicação (DJ de 28.05.2007) do julgado pelo Egrégio Superior Tribunal de Justiça, por sua Corte Especial, que, em sede de Embargos de Divergência em Recurso Especial (EREsp n ${ }^{\circ}$ 440.837-RS), fixou o entendimento pela admissibilidade da averbação do protesto contra alienação de bens imóveis no registro predial, como expressão do poder geral de cautela do juiz e para proteção ao adquirente de boa fé, por via do princípio de publicidade; (...) Resolve: Artigo $1^{\circ}$ - O item 68.3 do Capítulo XX do Provimento CG no 58/89 (Normas de Serviço da Corregedoria Geral da Justiça - Serviços Extrajudiciais), passa a vigorar com a seguinte redação: '68.3. O protesto contra alienação de bens, o arrendamento e o comodato são atos insuscetíveis de registro, admitindo-se a averbação do protesto contra alienação de bens diante de determinação judicial expressa do juiz do processo'."
} 
dos protestos contra alienação de bens, enquanto seu anteprojeto - discutido no Primeiro Encontro de Jovens Processualistas - a excluía, estando previsto nos seguintes termos:

"§ $8^{\circ}$ A notificação, a interpelação o protesto contra alienação de bens, de que trata os arts. 867 a 873 da Lei n. ${ }^{\circ} 5.869$, de 11 de janeiro de 1973 (Código de Processo Civil), bem assim quaisquer outros procedimentos judiciais que não admitam o contraditório, não poderão ser objeto de averbação nos termos do inciso VIII, do $\S 1^{\circ}$. (sic) ${ }^{, 343}$

Quanto à possibilidade de averbação do ajuizamento da ação no registro imobiliário, já a sugerira, na forma de hipoteca judicial, PHILADELPHO AZEVEDO, como se observa do seguinte trecho de sua obra, que data de 1920: "para não surpreender a bôa fé de $3^{\text {os }}$ o melhor systema seria o da prenotação das acções reaes e a hypotheca judicial em bens do devedor por occasião do início das demais acções (...). O interessado apreciaria a probabilidade de exito das acções, o valor do risco etc. e si fizesse o negocio arcaria conscientemente com as responsabilidades sem poder allegar innocencia; seria isso preferivel a comprar na ignorancia bens litigiosos ou de modo a produzir a insolvencia do devedor, sendo affinal delles desapossado na execução e sem meios de ressarcimento."344

Em outras palavras, a averbação simplesmente garante a maior facilidade de acesso do terceiro à informação de que a ação está pendente, permitindo que este avalie o risco que a ação pendente repreentaria ao negócio. De nada adiantaria permitir a averbação apenas a partir da sentença de primeiro grau e manter o marco inicial da fraude de execução a partir do ajuizamento da ação, ou da citação, conforme o entendimento dominante. $\mathrm{O}$ resultado será invariavelmente a situação de insegurança vivenciada hoje.

Além disso, outras duas vantagens presentes na disciplina proposta pelos projetos de lei - e que contrabalanceiam o sistema - são a possibilidade de o interessado requerer o cancelamento ou a substituição do bem sobre o qual recaiu a averbação da

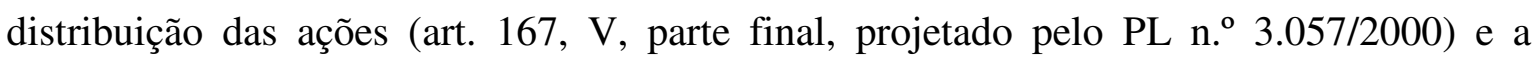
previsão do prazo de sessenta meses para a sua duração caso não haja prorrogação (art. $167, \S 4^{\circ}$, projetado também pelo PL n. $\left.{ }^{\circ} 3.057 / 2000\right)$.

\footnotetext{
${ }^{343}$ Textos de Anteprojetos Elaborados em 2008, Brasília: IBDP, 2008, item 7, p. 46.

${ }^{344}$ AZEVEDO, José Philadelpho de Barros e. Da fraude contra sentenças, cit., p. 39.
} 
Como já foi visto no item 4.2, supra, a possibilidade de substituição, redução ou cancelamento da averbação no registro público era medida salutar, criada pelo Decreto n. ${ }^{\circ}$ 18.542/1928 (art. 258, $\S 2^{\circ}$ ) em relação à hipoteca judiciária e existente até 1973, quando foi revogada pela atual Lei de Registros Públicos. Por tal medida, assegurava-se ao devedor a possibilidade de transferir a averbação da hipoteca judicial a outros bens, permitindo-o alienar o anteriormente objeto da averbação.

Impedia-se, com isso, que o credor, originalmente quirografário, adquirisse status de credor real, mediante a adstrição de determinado bem à garantia de seu crédito, como ocorre na hipoteca convencional. O retorno dessa norma ao ordenamento jurídico tornaria o sistema mais equilibrado, ainda mais se se considerar que o arco temporal seria ampliado, sendo a averbação possível já desde o ajuizamento da demanda.

Por fim, a previsão do prazo de duração de sessenta meses para as averbações das distribuições viria para resolver problema existente no atual sistema do artigo 615-A do CPC. De fato, referido artigo não prevê hipótese de cancelamento do registro, principalmente nos casos em que o credor deixar de informar a realização da averbação no processo. Nesse caso, a norma projetada apresenta solução adequada ao prever o cancelamento automático da averbação, impedindo que permaneçam averbadas no registro imobiliário, o ajuizamento de processos há muito extintos.

No entanto, há também desvantagens nas propostas feitas nesses projetos de lei. A principal delas é insistir na modificação da disciplina da fraude de execução instituto de direito processual - por meio de alterações na Lei de Registros Públicos.

Conforme analisado ao longo desta tese, tal prática mostrou-se extremamente prejudicial ao instituto da fraude de execução, pois, de um lado, dificultou muito sua interpretação, dada a constante necessidade de conjugação de várias normas a serem aplicadas e, de outro lado, tornou-o particularmente vulnerável às alterações legislativas não sincronizadas, tal como vem ocorrendo desde 1939.

Além disso, se, na década de 1920, havia motivo para PHILADELPHO AZEVEDO inserir normas de natureza processual na legislação relativa aos registros 
públicos, uma vez que essa era nacional, enquanto os códigos processuais eram estaduais e dificilmente poder-se-ia operacionalizar a reforma de todos eles -, atualmente, não há qualquer razão para isso. ${ }^{345}$

Tanto o CPC, quanto a Lei n. $^{\circ}$ 6.015/1973 são leis ordinárias, com matéria afeta à competência da União Federal, de modo que sua alteração é feita da mesma forma, pelo mesmo órgão e mediante o mesmo quorum, não havendo sentido em preferir alocar novas regras sobre a fraude de execução na lei relativa a registros públicos.

Tal opção seria, ainda, necessariamente parcial, tendo em vista que a Lei n. ${ }^{\circ}$ 11.382/2006 ampliou a possibilidade de averbações da penhora e da distribuição da execução para outros bens que não imóveis, em outros registros públicos, como o de veículos automotores, participações societárias etc. (cf. art. 615-A e 659, $\S 4^{\circ}$ e $6^{\circ}, \mathrm{CPC}$ ). Dessa forma, a alteração das regras da fraude de execução somente em relação ao registro de imóveis contribuiria para tornar mais fragmentada a disciplina do instituto, prejudicando ainda mais a sua já difícil interpretação.

Ao lado dessa desvantagem inicial, há ainda outra que diz respeito à previsão, no artigo 172 projetado $\left(\S \S 7^{\circ}\right.$ e $8^{\circ}$ dos PL n. ${ }^{\text {os }} 3.057 / 2000$ e 5.159/2009, respectivamente), no sentido de que, a averbação da pendência da ação real ou reipersecutória "torna absoluta, para os efeitos do art. 219 do Código de Processo Civil, a presunção de conhecimento por terceiros da litigiosidade da coisa".

Da forma como está redigida, fazendo menção que tal presunção é "para efeitos do art. 219 do Código de Processo Civil" a norma contribuirá apenas para aumentar a dificuldade de interpretação, uma vez que tal artigo não atribui qualquer consequência à boa-fé do terceiro.

\footnotetext{
${ }^{345}$ Cf. a justificativa de Philadelpho Azevedo: "dada, porem, a intima connexão desses preceitos com o regimen immobiliario, (...) seria preferível que partisse de uma lei federal a adoção dessas excellentes medidas, aproveitando-se, por exemplo, o projecto do Sr. Maximiniano de Figueiredo de regulamentação dos registros publicos" (Da fraude contra sentenças, cit., p. 42).
} 
Ademais, em relação à hipótese de fraude de execução do artigo 593, I, do CPC, já demonstramos nesta tese que a boa-fé do terceiro é absolutamente irrelevante em razão da própria inoponibilidade erga omnes de que já gozam os direitos reais.

\section{2- Sugestão alternativa para a disciplina futura da fraude de execução}

Alternativamente às alterações propostas nos PLs n..$^{\circ}$ 3.057/2000 5.951/2009, sugere-se, nesse item um novo rumo a ser trilhado, aproveitando-se das vantagens já presentes nessa propostas, superando as desvantagens acima apontadas e outras que foram sendo verificadas ao longo da análise empreendida nesta tese.

Pela análise histórica do capítulo 4 , vimos que duas são as causas da indefinição quanto à feição e à relevância que o elemento subjetivo para a configuração da fraude de execução.

Sua origem mais recente é precisamente o descompasso entre a legislação processual e registrária, surgido com a mudança da disciplina tradicional da fraude de execução pelo Código de Processo Civil de 1939 e agravado com as alterações da Lei n. ${ }^{\circ}$ 6.015/1973 e das reformas processuais de 1994, 2002 e 2006. Em relação a esse ponto, os projetos de lei apenas perpetuam - e talvez até agravarão - esse problema.

Já a origem mais remota do problema identificado consiste na iniquidade que certas hipóteses legais de fraude de execução, por abstraírem totalmente a relevância do elemento subjetivo, geram em relação a terceiros de boa-fé. Diante desses casos, historicamente a jurisprudência tem procurado adotar interpretação que, fugindo ao rigor do texto legal, acabe por admitir a discussão desse elemento.

Tal problema acompanha o instituto desde o seu surgimento no direito processual brasileiro, inicialmente em relação às hipóteses de alienação de bem litigioso e de bem penhorado, previstas nos $\S \S 1^{\circ}$ e $2^{\circ}$ do art. $494^{\circ}$ do Reg. 737/1850. Nas décadas de 1920 e 1930, houve grande avanço na tentativa de sua solução graças aos esforços de 
Philadelpho AzEVEDo, que instituiu novas formas de utilização do registro de imóveis para proporcionar maior facilidade de ciência pelos terceiros, tendo alguns códigos processuais até mesmo atrelado a configuração dessas hipóteses de fraude de execução à necessidade de inscrição da citação da ação real ou reipersecutória e da penhora, como o Código de Processo Civil e Comercial do Estado de São Paulo (cf. art. 950, I) e, apenas em relação aos bens penhorados pelo artigo 969, III, do código do Distrito Federal.

Grande parte desse avanço foi perdido com as alterações trazidas pelo Código de Processo Civil de 1939, em especial a supressão da hipótese de fraude de execução decorrente da alienação de bem penhorado e da menção à "existência de razão para que o terceiro soubesse da pendência de ação contra o devedor que pudesse reduzi-lo à insolvência", hipótese correspondente ao $§ 3^{\circ}$ do art. 494º do Regulamento 737/1850. Essa era a expressão que permitia a investigação da presença da má-fé do terceiro e sua supressão provocou o surgimento do entendimento dominante.

Nesse ponto, os projetos de lei trazem novos avanços, em especial a possibilidade de averbação da notícia da pendência da ação desde o seu ajuizamento, que conta ainda com a possibilidade de substituição do bem em cujo registro público foi feita essa averbação e o estabelecimento prazo de duração para tal averbação, uma vez que se trata de ato provisório por natureza, devendo ser substituída pela averbação da penhora. Por fim, outro importante avanço incorporado nesses projetos de lei é a interpretação de que a averbação do ato processual no registro público tem por fim da publicidade ao ato, apenas eliminar a possibilidade de alegação de boa-fé pelo terceiro.

O novo rumo que sugerimos seria implementar essas importantes alterações e avanços para o regime da fraude de execução não por meio de alteração na Lei n. ${ }^{\circ}$ 6.015/1973, mas por alterações no Código de Processo Civil, eliminando, assim a fragmentação de sua disciplina legal antes mencionada. Na legislação relativa aos registros públicos, permaneceria a regulamentação relativa apenas à matéria registrária (previsão dos atos que podem ser registrados ou averbados, requisitos para o seu registro, custas etc.) e não aos efeitos - processuais - quanto à configuração da fraude de execução. 
Aproveitando-se o ensejo da implementação de tais avanços, outras correções poderiam ser feitas, desde as mais simples, como a previsão, no $\S 4^{\circ}$ do artigo 659 do CPC da possibilidade de averbação da penhora também em bens móveis sujeitos a registro, até outras de maior envergadura, como o restabelecimento da hipótese de fraude de execução decorrente da alienação de bem penhorado, arrestado ou sequestrado, suprimindo a lacuna criada pelo código de 1939 que tanta discussão ainda causa e restaurando-se o alinhamento com o artigo 167, I, 5, da Lei n. ${ }^{\circ}$ 6.015/1973. E, ainda, a supressão da hipótese do inciso III do artigo 593 do CPC, uma vez que os casos de crédito tributário e a alienação no período suspeito da falência não precisam da remissão feita por esse inciso; já existindo antes mesmo dessa norma.

Com a criação da possibilidade de averbação do ajuizamento da ação desde a fase de conhecimento, que poderia ser prevista por meio de acréscimo no artigo 263 do CPC, ${ }^{346}$ perderiam sentido, devendo ser revogadas, as disposições sobre a hipoteca judiciária (art. 466, CPC) - instituto pouquíssimo utilizado entre nós - e averbação da distribuição da execução (art. 615-A, CPC) - instituto também envolto em polêmica.

Com essas alterações, mantida a hipótese de fraude de execução prevista no inciso I do artigo 593 do CPC, com a possibilidade de registro de seu ajuizamento para os fins regulados no direito material, quase um século depois de sua idealização, o brilhante sistema idealizado por PHILADELPHO AZEVEDO em sua obra. ${ }^{347}$

No entanto, considerando as alterações sociais e econômicas antes mencionadas com apoio em LEONARDO GRECO, ${ }^{348}$ bem como os avanços, principalmente na década de 1930, no sistema de busca nos distribuidores forenses, ${ }^{349}$ um sistema completo de combate à fraude de execução não poderia se basear apenas nas certidões de registros públicos. Assim, também devem ser contemplados no novo dispositivo sobre a matéria a possibilidade de o terceiro ter razão para saber da existência da ação devido à sua

\footnotetext{
${ }^{346}$ Cf. Apêndice 4.

${ }^{347}$ Cf. AZEVEDO, José Philadelpho de Barros e. Da fraude contra sentenças, cit., p. 39.

${ }^{348}$ GRECO, Leonardo. Em busca da efetividade do processo de execução, cit., p. 156.

${ }^{349}$ Dada a tecnologia atual e a existência do Conselho Nacional de Justiça, poderia até mesmo evoluir para a implantação, em nível nacional, do registro geral idealizado por Alcântara Machado para o Judiciário paulista naquela época. Um primeiro passo nesse sentido, já pode ter sido dado com a unificação dos registros processuais prevista na Resolução CNJ n. ${ }^{\circ}$ 65, de 18 de dezembro de 2008.
} 
diligência junto a tais distribuidores ou devido a outras razões normalmente baseada nas presunções clássicas de fraude.

Tendo por base a análise aqui empreendida, esboçamos, no Apêndice 4 desta tese, sugestões de alteração para os artigos 263, 593 e 659 do CPC, no sentido do mencionado nesse capítulo. 


\section{9- CONCLUSÃO}

Partimos, nesta tese, de pergunta para a qual não havia ainda uma resposta definitiva: seria relevante para a configuração dos casos de fraude de execução previstos no artigo 593 do CPC a boa ou a má-fé das pessoas nelas envolvidas?

Dado o descompasso existente entre os dispositivos que regem a matéria, as posições a seu respeito vão de um extremo ao outro, passando por uma plêiade de correntes intermediárias sem que haja uma explicação satisfatória ao problema.

O entendimento dominante atribui relevância exacerbada ao elemento subjetivo e o generaliza para todos os casos de fraude de execução, limitando a aplicação do instituto de tal forma, que chega praticamente a anulá-lo.

Em busca da resposta a essa questão, rastreamos as alterações legislativas que deram origem ao descompasso atual, especificamente na disciplina dada pelo Código de Processo Civil de 1939. Prosseguindo na análise, resgatamos a feição e a relevância que eram atribuídas ao elemento subjetivo desde a origem da fraude de execução em 1850.

Essa análise corroborou nossa hipótese original, qual seja: a de que o elemento subjetivo não é relevante para a configuração da fraude de execução em todos os casos do artigo 593. Ao contrário, nas hipóteses de pendência de ação fundada em direito real (art. 593, I, CPC), naquelas em que a pendência de ação que possa reduzir o devedor à insolvência constar de registro público (arts. 593, II, c/c 466, 659, § 4º e 615-A, todos do $\mathrm{CPC}$ ); e até mesmo em outras legalmente previstas, como a do ato praticado no período suspeito da falência (arts. 593, III, c/c 129 da Lei n. ${ }^{\circ}$ 11.101/2005), a boa ou má-fé do terceiro é irrelevante para a configuração da fraude de execução.

Nos demais casos, em que o elemento subjetivo seja, de fato, relevante para a configuração da fraude de execução, demonstramos que a investigação deve se limitar à esfera do terceiro, aferindo se havia ou não razão para esse saber da pendência da demanda, e não exigir prova de sua ciência efetiva.

Ainda em contraposição ao entendimento dominante - que atribui ao credor o ônus da prova da presença do elemento subjetivo - demonstramos, com base em 
lição de BARBOSA MOREIRA, não haver regra legal alterando a distribuição dos ônus da prova nesse caso.

Entre as vantagens da hipótese proposta, encontra-se a possibilidade de uma aplicação mais ampla e, ao mesmo tempo, mais segura do instituto, permitindo inclusive a sugestão de metodologia - baseada nas leis vigentes - para o reconhecimento da fraude de execução em seus diversos casos.

Diante da existência de projetos de lei versando sobre o assunto, propomos, à luz da análise feita nesta tese, rumo alternativo para restabelecer e aprimorar a disciplina original da fraude de execução, proporcionando maior segurança na aplicação do instituto. 


\section{REFERÊNCIAS BIBLIOGRÁFICAS}

ADONI, André Luis. O reconhecimento da fraude de execução em embargos de terceiro: breve reflexão sobre a visão do Tribunal de Justiça acerca da boa-fé do terceiro adquirente. Revista Jurídica Logos, São Paulo, n. 3, p. 7-16, jan./dez. 2007.

ALBUQUERQUE, Magnus Augusto Cavalcanti de. A compra e venda de bens penhorados. Revista dos Tribunais, São Paulo, v. 76, n. 620, p. 259-261, jun. 1987.

ALMEIDA, Cândido Mendes de. Código Philipino ou Ordenações e Leis do Reino de Portugal. Rio de Janeiro: Typ. do Instituto Philomathico, 1870. Livro III e Livro IV.

ALTEMANI, Nelson. Fraude de execução. RJTJSP, São Paulo, n. 40, p. 19-34, maio/jun. 1976.

ALVIM, Arruda. O terceiro adquirente de bem imóvel do réu, pendente ação reivindicatória não inscrita no registro de imóveis, e a eficácia da sentença em relação a esse terceiro, no direito brasileiro. Revista de Processo, São Paulo, v. 8, n. 31, p. 189-198, jul./set. 1983.

AMADEO, Rodolfo da Costa Manso Real. Embargos de terceiro: legitimidade passiva. São Paulo: Atlas, 2006.

AMADEO, Rodolfo da Costa Manso Real. O novo procedimento da execução de título executivo judicial de obrigação de pagar quantia. In: CARMONA, Carlos Alberto (Coord.). Reflexões sobre a reforma do Código de Processo Civil: estudos em homenagem a Ada Pellegrini Grinover, Cândido R. Dinamarco e Kazuo Watanabe. São Paulo: Atlas, 2007. p. 281-315.

AMADEO, Rodolfo da Costa Manso Real. Reflexões sobre a averbação do ajuizamento da execução: artigo 615-A da Lei n. ${ }^{\circ}$ 11.382, de 6 de dezembro de 2006. In: COSTA, Susana Henriques da (Coord.). Execução extrajudicial: modificações da Lei $n .^{\circ}$ 11.382/2006. São Paulo: Quartier Latin, 2007. p. 157-172.

AMENDOEIRA JR., Sidnei. Execução e impugnação da sentença arbitral. In: SHIMURA, Sérgio; WAMBIER, Tereza Arruda Alvim (Coords.). Processo de execução e assuntos afins. São Paulo: Ed. Revista dos Tribunais, 2001. v. 2, p. 685-721.

AMERICANO, Jorge. Comentários ao Código do Processo Civil do Brasil. São Paulo: Saraiva, 1943. v. 4. 
AMERICANO, Jorge. Commentarios ao Codigo do Processo Civil e Commercial do Estado de São Paulo. São Paulo: Saraiva, 1934. v. 1.

AMERICANO, Jorge. Da acção pauliana. 2. ed., São Paulo: Saraiva, 1932.

AMORIM FILHO, Agnelo. Critério científico para distinguir a prescrição da decadência e para identificar as ações imprescritíveis. Revista de Direito Processual Civil, v. 3, P. 95 132, jan./jun. 1961.

ANDRIGHI, Fátima Nancy. O Registro da penhora e a reforma do Código de Processo Civil. In: TEIXEIRA, Sálvio de Figueiredo (Coord.), Reforma do Código de Processo Civil. São Paulo: Saraiva, 1996.

ANDRIGHI, Fátima Nancy. O registro da penhora e a reforma do Código de Processo Civil. Revista de Processo, São Paulo, v. 20, n. 80, p. 7-9, out./dez. 1995.

ANKUM, H. Interditum fraudatorium et restitutio in integrum ob fraudem. In: ARANGIORUIZ, Vincenzo. Synteleia, Napoli: Javene, 1964.

ARAGÃO, Evaristo; MEDEIROS, Maria Lúcia L. C. de. A fraude de execução e o terceiro adquirente. In: SHIMURA, Sérgio; WAMBIER, Tereza Arruda Alvim (Coords.). Processo de execução e assuntos afins. São Paulo: Ed. Revista dos Tribunais, 2001. v. 2, p. 343-358.

ARAGÃO, Severiano Ignácio de. Fraude à execução ou à ação condenatória. $A D V$ Advocacia Dinâmica, São Paulo, v. 10, n. 4, p. 31, jan. 1990.

ARAÚJO CINTRA, Antônio Carlos de; GRINOVER, Ada Pellegrini; DINAMARCO, Cândido Rangel. Teoria geral do processo. 16. ed. São Paulo: Malheiros, 2000.

ARAÚJO, José Henrique Mouta. Novas perspectivas ligadas à fraude à execução: comentários ao art. 615-A do CPC. Revista Dialética de Direito Processual, São Paulo, n. 63, p. 59-64, jun. 2008.

ARMANDO, Nicanor N. Fraude aos credores e à execução perante os tribunais. Belo Horizonte: UFMG, 1967.

ARMELIN, Donaldo. O processo de execução e a reforma do Código de Processo Civil. In: TEIXEIRA, Sálvio de Figueiredo (Coord.), Reforma do Código de Processo Civil. São Paulo: Saraiva, 1996.

ARMELIN, Donaldo. Registro da penhora e fraude de execução. Revista do Advogado, São Paulo, n. 40, p. 69-75, jul. 1993. 
ASSIS, Araken de. Comentários ao Código de Processo Civil. 2. ed. Rio de Janeiro: Forense, 2003.

ASSIS, Araken de. Fraude à execução e legitimidade do terceiro hipotecante. Revista Jurídica, n. 168, p. 5-20, out. 1991.

ASSIS, Araken de. Manual da execução. 12. ed. São Paulo: Ed. Revista dos Tribunais, 2009.

ASSIS, Araken de. Manual do processo de execução. 8. ed. São Paulo: Ed. Revista dos Tribunais, 2002.

ASSIS, Carlos Augusto de. Fraude à execução e boa-fé do adquirente. Genesis: Revista de direito processual civil. Curitiba, v. 5, n. 16, p. 224-240, abr./jun. 2000.

ASSIS, José Eduardo Ribeiro de. Termo inicial à caracterização da fraude à execução. In: TUBENCHLAK, J.; BUSTAMANTE, R. (Coords.). Livro de estudos jurídicos. Rio de Janeiro: Instituto de Estudos Jurídicos, 1991. v. 7, p. 237-241.

ATEM, Abraão, A fraude de execução na alienação onerosa. Revista dos Tribunais, São Paulo, n. 242, p. 33-34, dez. 1955.

AZEVEDO JÚNIOR, José Osório de. A Súmula 621 do STF e o imóvel loteado. Revista dos Tribunais, São Paulo, n. 611, p. 276-279, set. 1986.

AZEVEDO, Alvaro Villaça. Código Civil comentado. São Paulo: Atlas, 2003. v. 2.

AZEVEDO, Antônio Junqueira de. Negócio jurídico, existência, validade e eficácia. 4. ed. São Paulo: Saraiva, 2002.

AZEVEDO, José Philadelpho de Barros e. Da fraude contra sentenças. Rio de Janeiro: Faculdade Livre do Rio de Janeiro, 1920.

AZEVEDO, Luiz Carlos de. Da penhora. São Paulo: Resenha Tributária e FIEO, 1994.

AZEVEDO, Luiz Carlos de. Fraude contra credores. Revista da Escola Paulista da Magistratura, São Paulo, v. 3, n. 1, p. 53-65, jan./jun. 2002.

BARBOSA MOREIRA, José Carlos. A Emenda Constitucional 45 e o processo. In: Temas de direito processual: nona série. São Paulo: Saraiva, 2007. 
BARBOSA MOREIRA, José Carlos. Anotações sobre o título da prova do novo Código Civil. In: Temas de direito processual: nona série. São Paulo: Saraiva, 2007. p. 141158.

BARBOSA MOREIRA, José Carlos. Cumprimento e execução de sentença: necessidade de esclarecimentos conceituais. In: . Temas de direito processual: nona série. São Paulo: Saraiva, 2007. p. 315-332.

BARBOSA MOREIRA, José Carlos. Invalidade e ineficácia do negócio jurídico. Revista de Direito Privado, São Paulo, v. 4, n. 15, p.217-229, jul./set. 2003.

BARBOSA MOREIRA, José Carlos. Notas sobre a efetividade do processo. In: Temas de direito processual: terceira série. São Paulo: Saraiva, 1984.

BARBOSA MOREIRA, José Carlos. O novo processo civil brasileiro. 21. ed. Rio de Janeiro: Forense, 2001.

BARBOSA MOREIRA, José Carlos. Presunções e prova. In: Temas de direito processual: primeira série. 2. ed. São Paulo: Saraiva, 1988. p. 55-71.

BARBOSA MOREIRA, José Carlos. Presunções e prova. In: Temas de direito processual: primeira série. 2. ed. São Paulo: Saraiva, 1988.

BARBOSA MOREIRA, José Carlos. Reflexões críticas sobre uma teoria da condenação civil. In: Temas de direito processual: primeira série. 2. ed. São Paulo: Saraiva, 1988. p. $72-80$.

BARCELOS, Pedro dos Santos. Fraude de execução. Revista dos Tribunais, São Paulo, v. 79, n. 658, p. 43-51, ago. 1990.

BASTOS, José Tavares. Código Judiciário do Estado do Rio de Janeiro. Rio de Janeiro: Jacintho Ribeiro dos Santos, 1919.

BAUMOHL, Debora Ines Kram. A nova execução civil: a desestruturação do processo de execução. São Paulo: Atlas, 2006.

BAYEUX FILHO, José Luiz. Fraude contra credores e fraude de execução. Revista de Processo, São Paulo, v. 16, n. 61, p. 250-256, jan./mar. 1991.

BEVILÁQUA, Clóvis. Código Civil dos Estados Unidos do Brasil. 2. ed. Rio de Janeiro: Ed. Rio, 1976. 
BEZERRA FILHO, Manoel Justino. Ação pauliana e embargos de terceiro: fraude contra credores e fraude de execução: possibilidade ou não de discussão da fraude contra credores em embargos de terceiro. Revista dos Tribunais, São Paulo, v. 73, n. 581, p. 25-34, mar. 1984.

BONAMIGO, Laércio Flávio. Fraude contra credores, fraude à execução e boa-fé: a jurisprudência e a Lei no 11.382/06. Informativo Jurídico Consulex, Brasília, n. 19, p.9-11, maio 2007.

BONÍCIO, Marcelo José Magalhães. A averbação e a fraude de execução na reforma do CPC: artigo 615-A. Revista Magister de Direito Civil e Processual Civil, Porto Alegre, n. 20, p. 68-69, set./out. 2007.

BONÍCIO, Marcelo José Magalhães. Apontamentos sobre a aparente necessidade de averbação para a configuração da fraude de execução segundo as novas regras do artigo 615-A do CPC. In: CARVALHO, Milton Paulo de. Direito Processual Civil. São Paulo: Quartier Latin, 2007. p. 367-373.

BONSIGNORI, Ângelo. L'Esecuzione forzata. Turim: G Giappichelli, 1996.

BRANDÃO, Karem. A alienação fraudulenta de bens sob a ótica do art. 615-A do CPC. Informativo Jurídico Consulex, Brasília, n. 25, p. 5-7, jun. 2007.

BRENNER, Ana Cristina. A fraude à execução examinada a partir da jurisprudência do Superior Tribunal de Justiça. Revista de Processo, São Paulo, n. 143, p. 186-200, jan. 2007.

BUENO, Cassio Scarpinella. A nova etapa da reforma do Código de Processo Civil. São Paulo: Saraiva, 2007.v. 3.

BUENO, Francisco da Silvera. Grande dicionário etimológico-prosódico da língua portuguesa. 2. tir. São Paulo: Saraiva, 1968. v. 1.

BÚRIGO, Vandré Augusto. A garantia do crédito tributário: a presunção de fraude à execução. Revista Dialética de Direito Tributário, São Paulo, n. 92, p. 83, maio 2003.

BUSSADA, Wilson. Fraude à execução e fraude contra credores interpretadas pelos tribunais. Bauru: Edipro, 1994.

CADIET, Loic. Code de Procédure Civile. 13. ed. Paris: Litec, 2000.

CAETANO, Marcello. História do direito português. Lisboa: Verbo, 2000. 
CAHALI, Yussef Said. Fraudes contra credores. 3. ed. São Paulo: Ed. Revista dos Tribunais, 2002.

CAIS, Frederico Fontoura da Silva. Embargos de terceiro e fraude à execução. Revista de Processo, São Paulo, v. 26, n. 102, p. 109-138, abr./jun. 2001.

CAIS, Frederico Fontoura da Silva. Fraude de execução. São Paulo: Saraiva, 2005.

CAMARA LEAL, Antônio Luiz da. Comentários ao Código de Processo Civil e Comercial do Estado de São Paulo. São Paulo: Liv. Acadêmica, 1930.

CAMBLER, Everaldo. Fraude de execução. Revista de Processo, São Paulo, v. 15, n. 58, p. 157-161, abr./jun. 1990, pp. 157/161.

CAMPBELL, Neil A. Biology. 4. ed. Menlo Park: Benjamin; Cummings, 1996.

CAMPOS, Gledson Marques de; DESTEFANI, Marcos. O novo art. 615-A e a fraude de execução. Revista Dialética de Direito Processual, São Paulo, n. 60, p. 53-62, mar. 2008.

CARMONA, Carlos Alberto. A arbitragem no processo civil brasileiro. São Paulo: Malheiros, 1993.

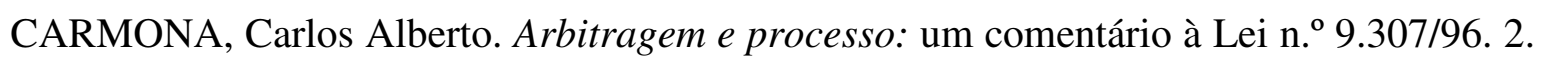
ed. São Paulo: Atlas, 2004.

CARMONA, Carlos Alberto. O processo de execução depois da reforma. In: TEIXEIRA, Sálvio de Figueiredo (Coord.), Reforma do Código de Processo Civil. São Paulo: Saraiva, 1996.

CARNELUTTI, Francesco. Lezioni di diritto processuale civile: processo di esecuzione. Padova: Cedam, 1932. v. 1.

CARNELUTTI, Francesco. Sistema di diritto processuale civile. Padova: Cedam, 1936 v. 1.

CARPI, Federico; COLESANTI, Vittorio; TARUFFO, Michele. Commentario breve al Codice di Procedura Civile. 4. ed. Milano: Cedam, 2002.

CARVALHO, Ernesto Antunes de. Reflexões sobre a configuração da fraude de execução segundo a atual jurisprudência do STJ. In: SHIMURA, Sérgio; WAMBIER, Tereza Arruda Alvim (Coords.). Processo de execução e assuntos afins. São Paulo: Ed. Revista dos Tribunais, 2001. v. 2, p. 314-342. 
CARVAlHO, Luiz Antonio da Costa. O Espírito do Código de Processo Civil. Rio de Janeiro: Labor, 1941.

CASCONI, Francisco Antonio. Fraude de execução. In: HARADA, Kiyoshi (Coord.). Temas de processo civil. São Paulo: Juarez de Oliveira, 2002.

CASSOL, Mariana Helena. Fraude e averbação da execução. IOB - Repertório de Jurisprudência: civil, processual, penal e comercial, São Paulo, v. 3, n. 2, p. 49-44, jan. 2008.

CASTRO, Amílcar de. Comentários ao Código de Processo Civil. Rio de Janeiro: Forense, 1941. v. 10.

CASTRO, Amílcar de. Comentários ao Código de Processo Civil. São Paulo: Ed. Revista dos Tribunais, 1974. v. 8.

CASTRO, Amílcar de. Ensaios Jurídicos. Revista Forense, Rio de Janeiro, n. 55, p. 147155, jul./dez. 1930

CAVALIERI FILHO, Sérgio. Programa de responsabilidade civil. 7. ed. São Paulo: Atlas, 2007.

CENEVIVA, Walter. Lei de Registros Públicos comentada. 10. ed. São Paulo: Saraiva, 1995.

CHICUTA, Kioitsi. Averbação do ajuizamento da execução no registro de imóveis: reflexos da alteração do CPC pela Lei n ${ }^{\circ}$ 11.382/2006. Revista do Advogado, São Paulo, v. 27, n. 90, p. 78-85, mar. 2007.

CHIOVENDA, Giuseppe. Instituições de direito processual civil. Trad. de Guimarães Menegale, notas de Enrico Tullio Liebman. São Paulo: Saraiva, 1965. v. 1

CODIGO do Processo Civil e Commercial do Estado do Rio Grande do Sul com a jurisprudencia do Superior Tribunal do Estado até 1920, com innumeros commentarios de doutrina e com as modificações introduzidas pelo Codigo Civil brasileiro. 2. ed. Porto Alegre: Livraria do Globo, 1922.

COELHO JUNIOR, Sérgio. Fraude de execução e garantias fundamentais do processo. Rio de Janeiro: Lumen Juris, 2006.

COMPARATO, Fábio Konder. Essai d'analyse dualiste de l'obligation en droit privé. Paris: Dalloz, 1964. 
CORRAL, D. Idelfonso L. García del. Cuerpo del derecho civil romano. Barcelona: Hermanos Kriegel, Hermann Y Osenbruggen, 1897. t.3.

CORRÊA, Wilson Leite. Da fraude de execução: aspectos polêmicos. Esmagis, Mato Grosso do Sul, n. 12, p. 119-130, jul. 2001.

COSTA JR., Paulo José. Comentários ao Código Penal: parte especial. 2. ed. São Paulo: Saraiva, 1989. v. 2.

COSTA, Moacyr Lobo da. Revogação da sentença. São Paulo: Ícone, 1995.

COSTA, Salustiano Orlando de Araujo. Código Commercial do Brasil. 7. ed. Rio de Janeiro: Livraria Francisco Alves, 1912. t. 2.

CRUZ E TUCCI, José Rogério. Limites subjetivos da eficácia da sentença e da coisa julgada civil. Tese (Titularidade) - Faculdade de Direito, Universidade de São Paulo, São Paulo, 2006.

CRUZ E TUCCI, José Rogério. Limites subjetivos da eficácia da sentença e da coisa julgada civil. São Paulo: Ed. Revista dos Tribunais, 2006.

CRUZ E TUCCI, José Rogério; AZEVEDO, Luiz Carlos de. Lições de história do processo civil romano. São Paulo: Ed. Revista dos Tribunais, 2001.

DALL AGNOL JUNIOR, Antonio Janyr. Fraude contra credores: estrutura e função. Ajuris, Porto Alegre, n. 58, p. 5-41.

DIAS, Maria Berenice. Fraude à execução (algumas questões controvertidas). Ajuris: revista da Associação dos Juízes do Rio Grande do Sul, Porto Alegre, v.17, n.50, p.72-81, nov. 1990.

DIAS, Ronaldo Brêtas de Carvalho. Da fraude à execução. Revista Forense, Rio de Janeiro, n. 290, p. 67-80, abr./jun. de 1985.

DIAS, Ronaldo Brêtas de Carvalho. Fraude à execução pela insolvência do devedor: alienação do imóvel penhorado: ausência de registro. Revista de Processo, São Paulo, v. 24, n. 94, p. 67-74, abr./jun. 1999.

DIAS, Ronaldo Brêtas de Carvalho. Fraude de execução: ausência de registro da penhora: alienações posteriores. Revista Jurídica da Procuradoria Geral da Fazenda Estadual, Belo Horizonte, n. 4, p. 42-50, out./dez. 1991. 
DIAS, Ronaldo Bretas de Carvalho. Fraude no processo civil. 2. ed. Belo Horizonte: Del Rey, 2000.

DIAS, Rosana Josefa Martins. Proteção ao processo: tutela cautelar, lealdade processual e fraude à execução. Rio de Janeiro: Renovar, 1994.

DINAMARCO, Cândido Rangel. A reforma da reforma. São Paulo: Malheiros, 2002.

DINAMARCO, Cândido Rangel. A reforma do Código de Processo Civil. 3. ed. São Paulo: Malheiros, 1996.

DINAMARCO, Cândido Rangel. As fraudes do devedor. In: Instituições de direito processual civil. 3. ed. São Paulo: Malheiros, 2009. v. 4.

DINAMARCO, Cândido Rangel. Bens impenhoráveis. In: Instituições de direito processual civil. 3. ed. São Paulo: Malheiros, 2009. v. 4.

DINAMARCO, Cândido Rangel. Desconsideração da personalidade jurídica, fraude e ônus da prova. In: Fundamentos do processo civil moderno. 3. ed. São Paulo: Malheiros, 2000. v. 4.

DINAMARCO, Cândido Rangel. Execução civil. 8. ed. Paulo: Malheiros, 2002.

DINAMARCO, Cândido Rangel. Fraude contra credores alegada nos embargos de terceiro. In: . Fundamentos do processo civil moderno. 3. ed. São Paulo: Malheiros, 2000. v. 1.

DINAMARCO, Cândido Rangel. Instituições de direito processual civil. 3. ed. São Paulo: Malheiros, 2009. v. 4.

DINAMARCO, Cândido Rangel. Instituições de direito processual civil. 6. ed. São Paulo: Malheiros, 2009. v. 2.

DONOSO, Denis. Sistematização da fraude de execução do art. 593, II, do CPC, em razão da alienação de imóveis: considerações sobre a boa-fé e o novo art. 615-A, parágrafo $3^{\circ}$. Revista Dialética de Direito Processual, São Paulo, n. 53, p. 27-43, ago. 2007.

ERPEN, Décio Antônio. A declaração da fraude à execução: consequiências e aspectos registrais. Revista dos Tribunais, v. 81, n. 675, p. 17-20, jan. 1992.

ERPEN, Décio Antônio. A fraude à execução e a nova lei das escrituras públicas. Revista dos Tribunais, São Paulo, v. 76, n. 624, p. 35-42, out. 1987. 
ERPEN, Décio Antônio. A fraude à execução e a publicidade registral. Revista dos Tribunais, São Paulo, n. 577, p. 21-29, nov. de 1983.

ERPEN, Décio Antônio. A fraude à execução e o desprestígio da função jurisdicional. Revista dos Tribunais, São Paulo, v. 80, n. 672, p. 80-89, out. 1991.

ERPEN, Décio Antônio. Das novas regras da execução e o registro imobiliário. Revista do Advogado, São Paulo, v. 27, n. 90, p. 22-33, mar. 2007.

ERPEN, Décio Antônio. Das novas regras da execução e o registro imobiliário: da reserva de prioridade: do bloqueio registral da Lei 11.382/2006 - artigo 615-A. Revista IOB de Direito Civil e Processual Civil, n. 53, p. 7-21, maio/jun. 2008.

ESPÍNOLA, Eduardo. Código de Processo do Estado da Bahia anotado. Bahia: Typ Bahiana, 1916.

FIGUEIREDO, Haroldo Cabral. Fraude de execução. Jurisprudência Brasileira, n. 104, p. 13-15, 1985.

FIGUEIREDO, Teixeira, Sálvio de. A presença admirável, no Império, do Conselheiro Lafayette Rodrigues Pereira. BDjur, Brasília, DF. Disponível em: <http://www.bdjur.stj.gov.br/dspace/handle/2011/8847>. Acesso em 24 nov. 2009.

FLAKS, Milton. Fraude de execução e fraude contra a fazenda. Revista Brasileira de Direito Processual, v. 34, p. 74, jul./ago. 1982.

FONSECA, Rodrigo Garcia da. Arbitragem e a reforma processual da execução. sentença parcial e cumprimento da sentença. Anotações em torno da Lei 11.232/2005. Revista de Arbitragem e Mediação, São Paulo, v. 4, n. 14, p. 30-47, jul./set. 2007.

FORNACIARI JÚNIOR, Clito. A reforma do Código de Processo Civil. São Paulo: Saraiva, 1996.

FORNACIARI JÚNIOR, Clito. A validade da alienação em fraude à execução. In Revista Nacional de Direito e Jurisprudência, Ribeirão Preto, v.9, n. 101, p. 11-12, maio de 2008.

FREITAS, Augusto Teixeira de. Consolidação das leis civis. 2. ed. Rio de Janeiro: Typ. Universal de Laemmert, 1865.

FUX, Luiz. O novo processo de execução: o cumprimento da sentença e a execução extrajudicial. Rio de Janeiro: Forense, 2008. 
GAMA FILHO, Fabiana. A fraude pauliana nos embargos de terceiro. Rio de Janeiro: Lumen Juris, 1997.

GOMES, Orlando. Direitos reais. 19. ed. rev. e atual. por Luiz Edson Fachin. Rio de Janeiro: Forense, 2008.

GONÇALVES, Luiz da Cunha. Tratado de direito civil. Coimbra: Coimbra Ed., 1932. v. 5.

GRANDINETTI, Eugenio Achille. Fraude à execução: pontos controvertidos. Jurisprudência Brasileira, n. 118, p. 13-25, 1987.

GRECO, Leonardo. Em busca da efetividade do processo de execução. Comunicações: Caderno do Programa de Pós-Graduação em Direito da Unimep, Piracicaba, ano 3, n. 1, p. 153-205, ago. 1998.

GUERRA FILHO, Willis Santiago, Responsabilidade patrimonial e fraude à execução. Revista de Processo, São Paulo, v. 17, n. 65, p.174-181, jan./mar. 1992.

GUIMARÃES, Hahnemann. Fraude de execução. Revista de Jurisprudência Brasileira, Rio de Janeiro, v. 82, p. 123-124, jan./fev. de 1949.

GUIMARÃES, Hahnemann. Revogação dos actos praticados em fraude de credores segundo o direito romano, Rio de Janeiro: Typ. D’A Encadernadora S.A., 1930.

GUSMÃO, Helvecio de. Código do Processo Civil e Commercial para o Districto Federal. Rio de Janeiro: Jacyntho Ribeiro dos Santos, 1931.

HANADA, Nelson. Da insolvência e sua prova na ação pauliana. 3. ed. São Paulo: Ed. Revista dos Tribunais, 1997.

HIRONAKA, Giselda Maria Novaes. Responsabilidade pressuposta. Belo Horizonte: Del Rey, 2005.

IMPALLOMENI, Giambattista. Fraudatorium interdictum. Labeo, Napoli, v. 23, n. 1, p. 83-91, 1977.

IMPALLOMENI, Giambattista. Studi sui mezzi di revoca degli atti fraudolenti nel diritto romano clássico. Padova: CEDAM, 1958.

JACOMINO, Sérgio. A averbação premonitória, publicidade registral e distribuidores: a probatio diabolica e o santo remédio. Boletim do IRIB em Revista, n. 331, p. 12, abr./jun. de 2007. 
JESUS, Damásio de. Código Penal anotado. 18. ed. atual. São Paulo: Saraiva, 2007..

LAGOEIRO, Manoel. Commentarios ao Codigo do Processo Civil. Belo Horizonte: Imprensa Official, 1930.

LEITÃO, Arthur de Freitas. Notas ao Processo Civil e Commercial-Regulamento 737, de 1850. 2. ed. São Paulo: C. Teixeira \& Cia, 1928.

LEITÃO, Arthur de Freitas. Regulamento 737, de 1850. São Paulo, 1920.

LENZ, Luis Alberto Thompson Flores. A natureza das normas processuais e o registro da penhora. Revista dos Tribunais, São Paulo, v. 77, n. 627, p. 60-68, jan. 1988.

LEONEL, Ricardo de Barros. Reformas recentes do processo civil. São Paulo: Método, 2007

LIEBMAN, Enrico Tullio. Embargos do executado: oposições de mérito no processo de execução. Tradução da 2. ed. italiana por J. Guimarães Menegale. 2. ed. São Paulo: Saraiva, 1968.

LIEBMAN, Enrico Tullio. Il titolo esecutivo riguardo ai terzi. Rivista di Diritto Processuale Civile, Padova, v. 11, p. 127-153, 1934. pt. 1.

LIEBMAN, Enrico Tullio. Pluralidade de partes legítimas à impugnação de um único ato. In: ___ Eficácia e autoridade da sentença e outros escritos sobre a coisa julgada. Tradução de Alfredo Buzaid e Benvindo Aires. Rio de Janeiro: Forense, 1945. p. 197-206.

LIEBMAN, Enrico Tullio. Processo de execução. Com notas de atualização do Prof. Joaquim Munhoz de Mello. 5. ed. São Paulo: Saraiva, 1986.

LIMA, Alcides de Mendonça. Comentários ao Código de Processo Civil. 3. ed. Rio de Janeiro: Forense, 1979. v. 6, t. 2.

LIMA, Alcides de Mendonça. Fraude de execução. Revista dos Tribunais, São Paulo, n. 485, p. 39-46, mar. 1976.

LIMA, Alcides de Mendonça. Processo de conhecimento e processo de execução. Rio de Janeiro: Forense, 1993.

LIMA, Alvino. A fraude no direito civil. São Paulo: Saraiva, 1965.

LIMA, Herotides da Silva. Código de Processo Civil brasileiro comentado. São Paulo: Saraiva, 1940. v. 1. 
LOBÃO, Manuel de Almeida e Sousa. Tratado encyclopedico, pratico e critico sobre as execuções. Lisboa: Nacional, 1865.

LOMBARDI, Mariana Capela. Da coisa julgada civil: limites subjetivos e extensão a terceiros. Dissertação (Mestrado) - Faculdade de Direito, Universidade de São Paulo, São Paulo, 2008.

LUCON, Paulo Henrique dos Santos. Fraude à execução, responsabilidade processual civil e registro da penhora. Revista Sintese de Direito Civil e Processual Civil, Porto Alegre, v. 1, n. 5, p. 131-144, maio/jun. 2000.

MACHADO, Sylvio Marcondes. Da relação obrigacional: dualismo conceitual. In: Problemas de direito mercantil. São Paulo: Max Limonad, 1970. p. 101-127.

MACHADO, Sylvio Marcondes. Do objeto de direito: patrimônio. In: . Problemas de direito mercantil. São Paulo: Max Limonad, 1970. p. 67-99.

MALHEIROS, Aristides Malheiros. Codigo do Processo Civil e Commercial do Est. de São Paulo. São Paulo: Ed. Revista dos Tribunais, 1930.

MANSO, Manoel da Costa. Votos e accordams: julgamentos proferidos no Tribunal de Justiça do Estado de S. Paulo. São Paulo: Saraiva, 1922.

MARCATO, Antonio Carlos (Coord.). Código de Processo Civil interpretado. 3. ed. São Paulo: Atlas, 2008.

MARMITT, Arnaldo. A penhora. 3. ed. Rio de Janeiro: Aide, 2003.

MARQUES, José Frederico. Instituições de direito processual civil. 3. ed. Rio de Janeiro: Forense, 1971. v. 5.

MARTINS, Pedro Batista. Em defesa do ante-projeto de Código de Processo Civil. Revista Forense, Rio de Janeiro, n. 78, abr./jun. 1939.

MARTINS, Pedro Batista; LEAL, Victor Nunes. Código de Processo Civil com índice alfabético e analítico precedido da Exposição de Motivos do Ministro Francisco Campos. Rio de Janeiro: José Olympio, 1939.

MATHEUS, Rodrigo. Registro da penhora e fraude à execução. Revista de Processo, São Paulo, v. 23 n. 92, p. 125-142, out./dez. 1998.

MAXILIANO, Carlos. Hermenêutica e aplicação do direito. 19. ed. Rio de Janeiro: Forense, 2001. 
MELLO JÚNIOR, David Alves de. Prova da propriedade de embarcação ou navio. Revista do Tribunal Regional do Trabalho da $11^{a}$ Região, Manaus, v. 5, n. 5, p. 30-32, 1997.

MELLO, Marcelo Augusto Santana de. A averbação premonitória introduzida pela Lei 11.382/2006. Boletim do IRIB em Revista, n. 331, abr./jun. 2007.

MELLO, Rogério Licastro Torres de. O responsável executivo secundário. São Paulo: Quartier Latin, 2006.

MELO, Marcelo Augusto Santana de. O registro de imóveis e o princípio da fé-pública registral. Revista de Direito Imobiliário, São Paulo, v. 30, n. 63, p. 53-81, jul./dez. 2007.

MESQUITA, José Ignacio Botelho de. Coisa julgada. Rio de Janeiro: Forense, 2004.

MESQUITA, José Ignacio Botelho de. Da ação civil. São Paulo: Ed. Revista dos Tribunais, 1975.

MESQUITA, José Ignacio Botelho de. Da ação de evicção. In: Teses, estudos $e$ pareceres de processo civil. São Paulo: Ed. Revista dos Tribunais, 2005. v. 1, p. 200-226.

MESQUITA, José Ignacio Botelho de. Limites ao poder do juiz nas cautelares antecipatórias. In: __ Teses, estudos e pareceres de processo civil. São Paulo: Ed. Revista dos Tribunais, 2007. v. 3.

MIRABETE, Julio Fabbrini. Manual de direito penal: parte especial. 20. ed. São Paulo: Atlas, 2003. v. 2.

MIRANDA, Francisco Cavalcanti Pontes de. Comentários ao Código de Processo Civil. Atualização legislativa por Sérgio Bermudes. 2. ed. rev. e aumen. Rio de Janeiro: Forense, 2001. t. 9.

MIRANDA, Francisco Cavalcanti Pontes de. Comentários ao Código de Processo Civil. 2. ed. Rio de Janeiro: Forense, 1961. t. 13.

MIRANDA, Francisco Cavalcanti Pontes de. Tratado de direito privado. Rio de Janeiro: Borsoi, 1954. t. 4.

MOLLICA, Luciano. Novos contornos para a fraude de execução na alienação de bem imóvel, sob a perspectiva de dinamizar os negócios imobiliários. 2009. Tese (Doutorado). Faculdade de Direito, Universidade de São Paulo, São Paulo, 2009. 
MONTEIRO NETO, Nelson. Ajuizamento da demanda, averbação no registro de imóveis e fraude à execução, novo art. 615-A do CPC: Lei 11.382. Revista Dialética de Direito Processual, São Paulo, n. 49, p. 107-111, abr. 2007.

MONTEIRO, Washington de Barros. Curso de direito civil: direito das coisas. 17. ed. São Paulo: Saraiva, 2003.

MOREIRA ALVES, José Carlos. Direito romano. Rio de Janeiro: Forense, 2001. v. 1.

MOREIRA, Fernando Mil Homens. Rápida exposição sobre a nova orientação da $3^{\mathrm{a}}$ turma do STJ a respeito do ônus da prova da (in)ocorrência de fraude à execução. Revista de Processo, São Paulo, v. 33, n. 161, p. 239-242, jul. 2008.

MOSCON, Cledi de Fátima Manica. Fraude de execução judicial. São Paulo: LTr, 2007.

MOURA, Mário Aguiar. Fraude contra credores e embargos de terceiro. Revista dos Tribunais, São Paulo, n. 617, p. 25-27, mar. 1987.

MOURA, Mário Aguiar. Fraude de execução pela insolvência do devedor. Revista dos Tribunais, São Paulo, n. 509, p. 296-303, mar. 1978.

NASCIMENTO, Cláudio Nunes do. Fraude de execução: caracterização: desnecessidade da inscrição da penhora. Revista dos Tribunais, São Paulo, n. 490, p. 19-21, ago. 1976.

NEGRÃO, Theotônio. Código de Processo Civil e legislação processual em vigor. 34. ed. São Paulo: Saraiva, 2002.

NERY JR., Nelson. Atualidades sobre o processo civil. São Paulo: Ed. Revista dos Tribunais, 1995.

NERY JR., Nelson. Código de Processo Civil Comentado. 10. ed. São Paulo: Ed. Revista dos Tribunais, 2007.

NERY JÚNIOR, Nelson. Fraude contra credores e os embargos de terceiro. Revista Brasileira de Direito Processual, Uberaba, n. 30, p. 55-70, 1981.

NERY JÚNIOR, Nelson; NERY, Rosa Maria Andrade. Código de Processo Civil comentado. 4. ed. São Paulo: Ed. Revista dos Tribunais, 1999.

NOLASCO, Rita Dias. Nova hipótese de fraude à execução. ASSIS, Araken et al. (Coord.). Direito civil e processo: estudos em homenagem ao professor Arruda Alvim. São Paulo: Ed. Revista dos Tribunais, 2007, p. 1425-1433. 
NONATO, Orozimbo. Fraude contra credores. Rio de Janeiro: Jurídica Universitária, 1969.

OLIVEIRA FILHO, J. de. A fraude de execução e o seu conceito legal. Archivo Judicario, suplemento, v. 49, p. 39-42, jun./mar. 1939.

OLIVEIRA, Antonio de Almeida. A lei das execuções. Rio de Janeiro: B. L. Garnier, 1887.

OLIVEIRA, Arthur Ribeiro de. Codigo do Processo Civil com annotações. Belo Horizonte: Imprensa Oficial, 1922.

OLIVEIRA, Arthur Ribeiro de. Commentarios do Projeto do Codigo do Processo Civil e Commercial da República dos Estados Unidos do Brasil. Rio de Janeiro: Imprensa Official, 1935.

OLIVEIRA, Carlos Alberto Alvaro. Alienação da coisa litigiosa. 2. ed. Rio de Janeiro: Forense, 1986.

OLIVEIRA, José Sebastião de. Fraude à execução. 2. ed. São Paulo: Saraiva, 1988.

OLIVEIRA, Paulo de. Atentado: fraude de execução. Revista Brasileira de Direito Processual, Uberaba, n. 53, p.174-180, jan./mar. 1987.

ORLANDI NETO, Narciso. Registro da penhora. Revista do Advogado, São Paulo, v. 27, n. 90, p. 104-112, mar. 2007.

PACHECO, José da Silva. Doação de imóvel feita por fiador de locação de imóvel alheio, antes da sentença que julgou ação de despejo. ADV Advocacia Dinâmica, São Paulo, v. 20, n. 42 , p. $652-650$, out. 2000 .

PACHECO, José da Silva. Fraude à execução: não demonstração pela parte credora de que o adquirente do bem sabia da existência da demanda contra o alienante. ADV Advocacia Dinâmica, São Paulo, v. 19, n. 33, p. 536-533, ago. 1999.

PAIVA, João Pedro Lamana. A fraude à execução e a averbação acautelatória e/ou premonitória à luz das inovações trazidas pelas Leis 11.382/2006 e 11.419/2006. Revista de Direito Imobiliário, n. 64, p. 155-162, jan./jun. 2008.

PARENTE, Eduardo de Albuquerque. A eficácia cautelar na averbação da demanda executiva. In: CIANCI, Mirna; QUARTIERI, Rita; MOURÃO, Luiz Eduardo; GIANNICO, Ana Paula C. (Coord.). Temas atuais das tutelas diferenciadas: estudos em homenagem ao prof. Donaldo Armelin. São Paulo: Ed. Revista dos Tribunais, 2009. 
PAUlA, Alexandre de. Código de Processo Civil anotado. 7. ed. São Paulo: Ed. Revista dos Tribunais, 1998. v. 3.

PAULA, Alexandre de. O processo civil à luz da jurisprudência. Rio de Janeiro: Forense, 1960. v. 27.

PAVAN, Dorival Renato; CARVALHO, Cristiane Costa. Da necessidade do registro da penhora como condição para se operar a fraude à execução: algumas considerações. Revista de Processo, São Paulo, v. 22, n. 88, p. 92-101, out./dez. 1997.

PEÑA, Ricardo Chemale Selistre. Fraude à execução. Porto Alegre: Livraria do Advogado, 2009.

PEREIRA, Caio Mário da Silva. Responsabilidade civil. 9. ed. Rio de Janeiro: Forense, 2001.

PEREIRA, Lafayette Rodrigues. Direito das coisas. Adaptação do Código Civil por José Bonifácio de Andrada e Silva. 5. ed. Rio de Janeiro: Freitas Bastos, 1943. v. 2.

PINTO, Rodrigo Strobel; TEIVE, Marcelo Muller. Averbação acional e constrição preliminar: críticas e sugestões ao pretenso art. 615-A do CPC, constante do Projeto de Lei 4.497/2004. Revista de Processo, v. 31, n. 138, p. 139-148, ago. 2006.

PORTUGAL NETO, Clotario de Macedo. Do conhecimento e declaração de fraude à execução nos próprios autos do processo de execução. Revista da Associação dos Magistrados do Paraná, Curitiba, v.5, n. 19, p. 410-414, jan./mar. 1980.

QUARTIERI, Rita. A averbação do ajuizamento da execução e reflexos na disciplina da fraude à execução. In: ASSIS, Araken et al. (Coords.). Direito civil e processo: estudos em homenagem ao professor Arruda Alvim. São Paulo: Ed. Revista dos Tribunais, 2007. p. $1435-1448$.

RAMOS, André de Carvalho. Fraude à execução e ciência inequívoca do litígio. Boletim dos Procuradores da República, São Paulo, v. 5, n. 57, p. 22-24, jan. 2003.

RESENDE, Ivana Herminia Ueda. A alienação de coisa litigiosa e a alienação de coisa sobre que incide constrição judicial. Revista de Doutrina e Jurisprudência do Tribunal de Justiça do Distrito Federal e Territórios, Brasília, n. 53, p. 13-23, jan./abr. 1997.

RESTIFFE, Paulo Sérgio. Fraude em execução: nova definição do marco temporal. Revista do Instituto dos Advogados de São Paulo, São Paulo, v. 9, n. 19, p. 258-273, jan./jun. 2007. 
RIBAS, Antonio Joaquim. Consolidação das Leis do Processo Civil commentada. Rio de Janeiro: Dias da Silva Junior, 1879. v. 2.

RIO GRANDE DO SUL. Codigo do Processo Civil e Commercial do Estado do Rio Grande do Sul. Edição Oficial. Porto Alegre: Officinas Typographicas d'A Federação, 1908.

RODRIGUES FILHO, Eulâmpio. Alienação em fraude de execução: ineficácia relativa. Revista de Crítica Judiciária, Rio de Janeiro, n. 5, p. 131-142, 1989.

ROSA, Luiz Carlos Goiabeira. Da fraude à execução antes da citação do devedor: da responsabilidade solidária do sócio na execução trabalhista. Revista do Curso de Direito da Universidade Federal de Uberlândia, Uberlândia, v. 29, n. 1/2, p. 39-46, dez. 2000.

SALAMACHA, José Eli. A fraude de execução no direito comparado. Revista de Processo, São Paulo, v. 31, n. 131, p. 96-116, jan. 2006.

SALAMACHA, José Eli. Fraude à execução no direito comparado e a nova modalidade de fraude à execução do art. 615-A do CPC. Revista de Direito Privado, São Paulo, n. 32, p. 75-97, out./dez. 2007.

SALAMACHA, José Eli. Fraude contra credores: efeitos da sentença na ação pauliana. Revista de Processo, São Paulo, v. 31, n. 135, p. 75-89, maio 2006.

SALAMACHA, José Eli. Fraude de execução: direitos do credor e do adquirente de boafé. São Paulo: Ed. Revista dos Tribunais, 2005.

SALAMACHA, José Eli. Reforma processual: o veto parcial aos arts. 649 e 650 da Lei 11.382/2006 e a nova modalidade de fraude à execução. In: ASSIS, Araken et al. (Coords.). Direito civil e processo: estudos em homenagem ao professor Arruda Alvim. São Paulo: Ed. Revista dos Tribunais, 2007. p. 1295-1322.

SANTINI, José Raffaelli. Fraude de execução: doutrina, prática, jurisprudência. São Paulo: LEUD, 1999.

SANTOS, Ernane Fidelis dos. Alienação da coisa litigiosa e intervenção de terceiros. Revista Dialética de Direito Processual, São Paulo, n. 8, p. 24-32, nov. 2003.

SANTOS, J. M. de Carvalho. Código de Processo Civil interpretado. Rio de Janeiro: Freitas Bastos, 1941. v. 10. 
SANTOS, Moacyr Amaral. Primeiras linhas de direito processual civil: adaptadas ao novo Código de Processo Civil. São Paulo: Saraiva, 1978.

SANTOS, Moacyr Amaral. Primeiras linhas de direito processual civil. 3. ed. São Paulo: Saraiva, 1979. v. 3.

SHIMURA, Sérgio. Arresto cautelar. 3. ed. São Paulo: Ed. Revista dos Tribunais, 2005.

SHIMURA, Sérgio. Título executivo. 2. ed. São Paulo: Método, 2005.

SILVA FILHO, Elvino. A insegura proteção registral nos negócios imobiliários do Brasil. Revista de Direito Imobiliário, São Paulo, n. 30, p. 7-31, jul./dez. 1992.

SILVA, Bruno Mattos e. Fraude à execução, registro imobiliário e boa-fé objetiva. Revista de Direito Imobiliário, São Paulo, v. 22, n. 47, p. 129-134, jul./dez. 1999.

SILVA, De Placido e. Comentários ao Código de Processo Civil. 3. ed. São Paulo: Guaíra, 1948. v. 4.

SILVA, De Placido e. Comentários ao Código de Processo Civil. 4. ed. Rio de Janeiro: [s.n.], 1956.

SILVA, Ederaldo Paulo da. Fraude à execução. Doutrina Adcoas, v. 7, n. 23, p. 466-468, dez. 2004.

SILVA, Mario Braule Pinto da. Execução: responsabilidade patrimonial. Revista Jurídica, Porto Alegre, n. 245, p. 34-36, mar. 1998.

SILVA, Nuno J. Espinosa Gomes da. História do direito português. Lisboa: Fundação Calouste Gulbenkian, 1991.

SILVA, Ovídio Araújo Baptista da. Comentários ao Código de Processo Civil. São Paulo: Ed. Revista dos Tribunais, 2000.

SILVA, Ovídio Araújo Baptista da. Curso de processo civil. São Paulo: Ed. Revista dos Tribunais, 2000. v. 1 e v. 2.

SOLAZZI, Siro. La revoca degli atti fraudolenti nel diritto romano. Napoli: DOTT, 1934.

SOUZA, Gelson Amaro de. Fraude à execução e a natureza do direito protegido. Revista Jurídica, Porto Alegre, v. 53, n. 336, p. 21-28, out. 2005. 
SOUZA, Gelson Amaro de. Fraude de execução e o direito de defesa do adquirente. São Paulo: Juarez de Oliveira, 2002.

SOUZA, Joaquim José Caetano Pereira e. Primeiras linhas sobre o processo civil. Coimbra: Imprensa Litteraria, 1872. t. 3.

TALAMINI, Eduardo; TALAMINI, Elmar Tobias.Embargos de terceiro - requisitos para caracterização de fraude à execução. Revista de Processo, São Paulo, n. 89, jan./mar. 1998.

TEIXEIRA, Sálvio de Figueiredo. A arbitragem no sistema jurídico brasileiro. Revista dos Tribunais, São Paulo, v. 86, n. 735, p. 38-48, jan. 1997.

TEIXEIRA, Sálvio de Figueiredo. Fraude de execução. Revista dos Tribunais, São Paulo, n. 609 , p. 7-14, jul. 1986.

TERRA, Marcelo. A fé pública registral. Revista de Direito Imobiliário, São Paulo, n. 26, p. 36-55, jul./dez. 1990.

TESHEINER, José Maria Rosa. Coisa litigiosa! Porto Alegre: CORAG, 1973.

THEODORO JÚNIOR, Humberto. A fraude de execução e o regime de sua declaração em juízo. Revista de Processo, São Paulo, v. 26, n. 102, p. 68-88, abr./jun. 2001.

THEODORO JÚNIOR, Humberto. A reforma da execução do título extrajudicial. Rio de Janeiro: Forense, 2007.

THEODORO JÚNIOR, Humberto. Alguns problemas pendentes de solução após a reforma da execução dos títulos extrajudiciais (Lei 11.382/2006). Revista de Processo, São Paulo, v. 33, n. 156, p. 10-35, fev. 2008.

THEODORO JÚNIOR, Humberto. Comentários ao novo Código Civil. Rio de Janeiro: Forense, 2003, v. 3, t. 1.

THEODORO JÚNIOR, Humberto. Crédito hipotecário: dação em pagamento: fraude de execução: conseqüências. Revista Dialética de Direito Processual, São Paulo, n. 53, p. 7485, ago. 2007.

THEODORO JÚNIOR, Humberto. Fraude contra credores e fraude de execução. Revista Síntese de Direito Civil e Processual Civil, Porto Alegre, v. 2, n. 11, p. 140-159, maio/jun. 2001.

THEODORO JÚNIOR, Humberto. Fraude contra credores: a natureza da sentença pauliana. 2. ed. Belo Horizonte: Del Rey, 2001. 
THEODORO JÚNIOR, Humberto. Fraude de execução. Alienação de bem pelo devedor quando em curso ação de conhecimento. Boa-fé do terceiro adquirente. Relevância do elemento subjetivo. Inconfiguração de fraude (Parecer). Revista Síntese de Direito Civil e Processual Civil, Porto Alegre, v. 1, n. 5, p. 145-159, maio/jun. 2000.

THEODORO JÚNIOR, Humberto. Processo de execução. 21. ed. São Paulo: LEUD, 2002.

THEODORO JÚNIOR, Humberto. Tutela jurisdicional dos direitos em matéria de responsabilidade civil: execução - penhora e questões polêmicas. Revista Síntese de Direito Civil e Processual Civil, Porto Alegre, v. 2, n. 12, p. 14-35, jul./ago. 2001.

TOLEDO, Paulo F. C. Salles de; ABRÃO, Carlos Henrique (Coords.), Comentários à Lei de Recuperação de Empresas e Falência, São Paulo: Saraiva, 2005.

TORTORO JÚNIOR, Carlos Augusto. A fraude de execução no Código de Processo Civil e suas implicações processuais: estudo analítico dos demais casos previstos em lei. Revista Nacional de Direito e Jurisprudência, Ribeirão Preto, v. 7, n. 76, p. 49-75, abr. 2006.

VIANNA, Ataliba. Inovações e obscuridades do Codigo do Processo Civil e Comercial brasileiro. São Paulo: Martins, 1940.

VIEIRA, Cícero Augusto (Org.). Projeto do Código de Processo Civil e Comercial dos Estados Unidos do Brasil. São Paulo: Brasileira, 1939.

VILLAR, Wilard de Castro. Processo de execução. São Paulo: Ed. Revista dos Tribunais, 1975.

WAMBIER, Luiz Rodrigues; TALAMINI, Eduardo. Curso avançado de processo civil. 10. ed. São Paulo: Ed. Revista dos Tribunais, 2009.

WAMBIER, Teresa Arruda Alvim. Nulidades do processo e da sentença. 6. ed. São Paulo: Ed. Revista dos Tribunais, 2007.

WELTER, Belmiro Pedro. Fraude de execução. 3. ed. Porto Alegre: Síntese, 1998.

WELTER, Belmiro Pedro. Fraude de execução: quando ocorre. Revista Jurídica, Porto Alegre, v. 45, n. 239, p. 5-13, set. 1997.

WINTER, Felipe Arthur. Fraude a execução. Revista de Processo, São Paulo, v. 16, n. 63, p. 184-189, jul./set. 1991. 
YARSHELL, Flávio Luiz. Antecipação da prova sem o requisito da urgência e direito autônomo à prova. São Paulo: Malheiros Ed., 2009.

YARSHELL, Flávio Luiz. Simulação e processo de execução. In: SHIMURA, Sérgio; WAMBIER, Teresa Arruda Alvim (Coords.). Processo de execução e assuntos afins. São Paulo: Ed. Revista dos Tribunais, 1998.

YOSHIKAWA, Eduardo Henrique de Oliveira. Do caráter objetivo da fraude à execução e suas consequências (artigo 593, II, do CPC). Revista Dialética de Direito Processual, n. 25 , p. 45, abr. 2005.

ZAVASCKI, Teori Albino. Comentários ao Código de Processo Civil. 2. ed. São Paulo: Ed. Revista dos Tribunais, 2003. v. 8.

ZAVASCKI, Teori Albino. Processo de execução: parte geral. 3. ed. São Paulo: Ed. Revista dos Tribunais, 2004.

ZULIANI, Ênio Santarelli. Jurisdição penal e civil: integração e conflitos. Revista do Advogado, São Paulo, v. 25, n. 81, p. 34-55, abr. 2005. 


\section{RESUMO}

Verificada a existência de diversos entendimentos conflitantes a respeito da relevância que a boa ou a má-fé desempenham para a configuração da fraude de execução e dos riscos decorrentes da indefinição quanto à matéria, propõe-se, nesta tese, a apresentação de nova hipótese interpretativa que, à luz da história e do regramento atual do instituto, identifique qual é e em que casos se faz relevante o elemento subjetivo na fraude de execução.

Para atingir esse objetivo, parte-se da análise das hipóteses de fraude de execução previstas na legislação em vigor e do estabelecimento de algumas premissas conceituais necessárias ao desenvolvimento do trabalho. Também no início da tese, é exposto o entendimento atualmente dominante na doutrina e na jurisprudência em relação à matéria, apresentando-se críticas em relação ao mesmo, com base em pesquisa de casos concretos julgados pelo Superior Tribunal de Justiça.

Em seguida, são identificadas a feição e a relevância do elemento subjetivo tal como originalmente apresentadas na história do instituto, confrontando-as com as que lhe estabelece entendimento dominante e demonstrando a sua prevalência tanto à luz da legislação em vigor, quanto em relação à moderna concepção da responsabilidade patrimonial.

A tese prossegue com a apresentação de sugestão de metodologia para análise dos casos de fraude de execução.

Finalmente, conclui-se o trabalho com a verificação das propostas legislativas para a disciplina futura da fraude de execução, apresentando-se sugestão alternativa, baseada na análise dos problemas verificados e na solução oferecida pela hipótese apresentada nesta tese. 


\begin{abstract}
Once verified the existence of many conflicting positions about the relevance that the good or bad faith may have on the configuration of the "fraude de execução" (literally: fraud of execution) and the risks deriving from the lack of definition about this subject, we propose, on this thesis, to present a new interpretative hypothesis which, on the light of the history and recent ruling of the institute, identifies what is the subjective element in the "fraude de execução" and in which cases it becomes relevant.
\end{abstract}

In order to achieve such aim, we start from the analysis of the hypothesis of "fraude de execução" foreseen in the current law and by establishing some conceptual premises that are necessary to the development of the work. Also, in the beginning of the thesis, we expose the prevailing position on the current jurisprudence and doctrine and criticize it based on the research of precedents of our Superior Court (Superior Tribunal de Justiça).

Afterwards, we identify the features and relevance of the subjective element such as originally presented on the history of the institute, comparing them with those established by the dominant position and demonstrating its prevalence, even on the light of the effective rules, than in relation to the modern concept of patrimonial responsibility.

The thesis continues with the suggestion of a methodology to analyze the cases of "fraude de execução".

Finally, the work is concluded with the study of the bills regarding the future ruling of the "fraude de execução" and an alternative suggestion is presented, based on the analysis of the problems verified and on the solution offered by the hypothesis presented on this thesis. 


\section{RIASSUNTO}

Verificata l'esistenza di diverse opinioni confliggenti riguardo la rilevanza che la buona o la mala fede rivestono nella configurazione della "fraude de execução" (alla lettera: frode di esecuzione) e dei rischi decorrenti dalla mancata definizione della materia, nella presente tesi si propone la presentazione di una nuova ipotesi interpretativa che, alla luce della storia e della regolamentazione attuale dell'istituto, identifichi cosa sia e in quali casi rivesta rilevanza l'elemento soggettivo nell'ambito della "fraude de execução".

Per raggiungere tale finalità, si parte dall'analisi delle ipotesi di “fraude de execução" previste nella legislazione vigente e dalla fissazione di alcune premesse concettuali necessarie allo svolgimento del lavoro. All'inizio della tesi, inoltre, viene esposto l'orientamento sulla materia attualmente predominante in seno alla dottrina e alla giurisprudenza, e vi si fanno delle critiche, sulla base della ricerca eseguita su dei casi concreti giudicati dal Superiore Tribunale di Giustizia.

In seguito, vengono identificate le caratteristiche e la rilevanza dell'elemento soggettivo originariamente presentate nel corso della storia dell'istituto, mettendole a confronto con quelle determinate dall'orientamento predominante, e se ne dimostra la prevalenza, alla luce sia della legislazione vigente, sia della moderna concezione della responsabilità patrimoniale.

La tesi prosegue con la presentazione di un suggerimento per una metodologia volta all'analisi dei casi di "fraude de execução".

Infine, il lavoro termina con la verifica delle proposte legislative per la disciplina futura della "fraude de execução", presentando un suggerimento alternativo, basato sull'analisi dei problemi verificati e sulla soluzione offerta dall'ipotesi presentata nel corso della tesi. 


\section{APÊNDICES}

\section{Apêndice 1 - Relatório da análise dos precedentes da súmula 375 do Superior Tribunal de Justiça}

A súmula 375, editada pela Corte Especial do Superior Tribunal de Justiça em 18 de março de 2009, com o seguinte enunciado: "o reconhecimento da fraude à execução depende do registro da penhora do bem alienado ou da prova de má-fé do terceiro adquirente," baseia-se em 21 acórdãos, julgados entre 1991 e 2008, sendo 3 da Segunda Seção; 2 da Primeira Turma; 4 da Segunda Turma, 4 da Terceira Turma; e 8 da Quarta Turma.

Buscando verificar em que consistiria a "má-fé" mencionada na súmula, bem como as provas que teriam sido admitidas para comprová-la nos casos em que o credor não registrara a penhora, analisamos cada um desses acórdãos, cujos dados encontram-se apresentados na Tabela 1 que segue esse relatório, ordenados por data de julgamento, do mais recente para o mais remoto.

Em nossa análise, levamos em consideração os seguintes elementos:

1) Coluna "Ato": identifica o tipo do ato jurídico praticado, se se tratava de alienação ou oneração de bens;

2) Coluna "Bem": identifica o tipo de bem objeto desse ato, se imóveis, veículos, linhas telefônicas etc.

3) Coluna "Momento processual": identifica o momento processual em que o ato foi praticado, dividindo-se em 4 momentos: (i) entre a propositura da ação e citação ("antes da citação"); (ii) entre a citação e a penhora ("antes da penhora"); (iii) entre a penhora e seu registro ("após a penhora"); e (iv) após o registro da penhora ("após o registro da penhora"). 
4) Coluna "Terceiro": identifica se o terceiro envolvido negociou diretamente com o devedor ("imediato") ou se negociou já com um terceiro ("mediato").

5) Coluna "Exige citação ou ciência do devedor?": identifica se o acórdão exigia, para a configuração da fraude de execução, a necessidade da ciência do devedor quanto à pendência da ação, seja por sua citação, seja pela existência de prova nesse sentido, a cargo do credor. Quando o ato havia sido praticado em momento processual outro que não "antes da citação", consta da planilha que o devedor já havia sido citado.

6) Coluna "Exige registro ou ciência do terceiro?": identifica se o acórdão exigia, para a configuração da fraude de execução, a necessidade de ciência do terceiro quanto à pendência da ação, seja em razão do registro da penhora, seja pela existência de prova nesse sentido, a cargo do credor. Quando a ausência de ciência do devedor foi motivo suficiente para o não reconhecimento da fraude de execução, consta da planilha "N/A", significando "não se aplica".

7) Coluna "Fraude de execução reconhecida?": identifica se, no caso apreciado no acórdão, a fraude de execução foi ou não reconhecida.

8) Coluna "Recurso provido?": identifica se o acórdão proveu ou não o recurso dirigido ao Superior Tribunal de Justiça.

Diante dos dados, a primeira observação que se faz é que em todos os acórdãos exigia-se a comprovação da efetiva ciência do terceiro e não da mera existência de razão para esse terceiro saber da ação pendente.

Além disso, verificou-se que, em nenhum dos acórdãos a fraude de execução foi reconhecida, impedindo a análise quanto à prova admitida para a demonstração da má-fé.

Em dois casos (REsp 734.280/RJ, j. 01.03.07 e REsp 140.670-GO, j. 14.10.07) a prática do ato deu-se antes da citação, sendo que, nesses, o não reconhecimento 
da fraude de execução fundou-se também na falta de citação (ou prova da ciência) do devedor, na linha da jurisprudência unânime do Superior Tribunal de Justiça.

Na análise, verificamos que dos 21 casos, em apenas 7, a penhora já havia sido realizada, de modo que, nos outros 14, o registro sequer era possível.

Vimos também que 10 dos precedentes versam sobre casos envolvendo terceiros imediatos e 11, terceiros mediatos, não fazendo qualquer distinção entre eles.

Por fim, observamos que cinco casos eram de execução fiscal, de modo que a hipótese de fraude de execução neles seria a dos artigos 185 do CTN c/c 593, III, do $\mathrm{CPC}$, sendo todos os outros referentes à hipótese prevista no inciso II desse último artigo. 
Tabela 1. Acórdãos Súmula 375.

\begin{tabular}{|c|c|c|c|c|c|c|c|c|c|}
\hline Recurso & $\begin{array}{l}\text { Data do } \\
\text { julgamento }\end{array}$ & Ato & Bem & $\begin{array}{l}\text { Momento } \\
\text { processual }\end{array}$ & Terceiro & $\begin{array}{c}\text { Exige } \\
\text { citação ou } \\
\text { ciência do } \\
\text { devedor? }\end{array}$ & $\begin{array}{c}\text { Exige } \\
\text { registro ou } \\
\text { ciência do } \\
\text { terceiro? }\end{array}$ & $\begin{array}{l}\text { Fraude de } \\
\text { execuçãoo } \\
\text { reconhecida? }\end{array}$ & $\begin{array}{l}\text { Recurso } \\
\text { provido? }\end{array}$ \\
\hline $\begin{array}{l}\text { REsp 865.974-RS } \\
\left(1^{\text {a }} \text { Turma }\right)\end{array}$ & 02.09 .08 & alienação & imóvel & antes da penhora & mediato & já citado & $\operatorname{sim}$ & não & não \\
\hline $\begin{array}{l}\text { REsp 810.170-RS } \\
\quad\left(2^{\mathrm{a}} \text { Turma }\right)\end{array}$ & 17.08.08 & alienação & imóvel & após a penhora & mediato & já citado & $\operatorname{sim}$ & não & não \\
\hline $\begin{array}{c}\text { Ag Rg no REsp } \\
\text { 1.046.004-MT } \\
\left(2^{\mathrm{a}} \text { Turma }\right)\end{array}$ & 10.06 .08 & $\begin{array}{l}\text { alienação (arrematação } \\
\text { judicial) }\end{array}$ & imóvel & antes da penhora & imediato & já citado & $\operatorname{sim}$ & não & não \\
\hline $\begin{array}{l}\text { REsp 495.914-SP } \\
\quad\left(4^{\mathrm{a}} \text { Turma }\right)\end{array}$ & 08.04 .08 & alienação & imóvel & após a penhora & mediato & já citado & $\operatorname{sim}$ & não & não \\
\hline $\begin{array}{l}\text { REsp 921.160-RS } \\
\left.\text { ( } 3^{\mathrm{a}} \text { Turma }\right)\end{array}$ & 08.02 .08 & alienação & imóvel & antes da penhora & imediato & já citado & $\operatorname{sim}$ & não & não \\
\hline 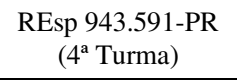 & 19.06.07 & alienação & imóvel & antes da penhora & mediato & já citado & $\operatorname{sim}$ & não & não \\
\hline $\begin{array}{l}\text { REsp 944.250-RS } \\
\quad\left(2^{\mathrm{a}} \text { Turma }\right)\end{array}$ & 07.08 .07 & alienação & veículo & antes da penhora & imediato & já citado & $\operatorname{sim}$ & não & não \\
\hline $\begin{array}{l}\text { EREsp 509.827-SP } \\
\left(2^{\mathrm{a}} \text { Seção) }\right.\end{array}$ & 25.04.07 & $\begin{array}{l}\text { alienação (compromisso de } \\
\text { compra e venda) }\end{array}$ & imóvel & antes da penhora & imediato & já citado & $\operatorname{sim}$ & não & $\begin{array}{c}\text { não } \\
\text { (o REsp.sim) }\end{array}$ \\
\hline $\begin{array}{l}\text { REsp 734.280-RJ } \\
\quad\left(2^{\mathrm{a}} \text { Turma }\right)\end{array}$ & 01.03 .07 & alienação & imóvel & antes da citação & imediato & $\operatorname{sim}$ & N/A & não & $\operatorname{sim}$ \\
\hline $\begin{array}{l}\text { REsp 739.388-MG } \\
\left(1^{\text {a }} \text { Turma }\right)\end{array}$ & 28.03.06 & alienação & imóvel & antes da penhora & mediato & já citado & $\operatorname{sim}$ & não & $\operatorname{sim}$ \\
\hline $\begin{array}{l}\text { EREsp 144.190-SP } \\
\quad\left(2^{\mathrm{a}} \text { Seção) }\right.\end{array}$ & 14.09 .05 & alienação (venda) & imóvel & antes da penhora & mediato & já citado & $\operatorname{sim}$ & não & $\begin{array}{c}\text { não } \\
\text { (o REsp.sim) }\end{array}$ \\
\hline $\begin{array}{l}\text { REsp 66.180-PR } \\
\quad\left(4^{\mathrm{a}} \text { Turma) }\right.\end{array}$ & 27.04 .99 & alienação & imóvel & após a penhora & imediato & já citado & $\operatorname{sim}$ & não & não \\
\hline $\begin{array}{l}\text { REsp 193.048-PR } \\
\quad\left(4^{\mathrm{a}} \text { Turma) }\right.\end{array}$ & 02.02 .99 & $\begin{array}{l}\text { alienação (distrato de } \\
\text { compra e venda e hipoteca) }\end{array}$ & imóvel & antes da penhora & imediato & já citado & $\operatorname{sim}$ & não & não \\
\hline $\begin{array}{l}\text { REsp 186.633-MS } \\
\text { (4 } 4^{\mathrm{a}} \text { Turma) }\end{array}$ & 29.10 .98 & alienação & imóvel & após a penhora & imediato & já citado & $\operatorname{sim}$ & não & $\operatorname{sim}$ \\
\hline $\begin{array}{l}\text { REsp 123.616-SP } \\
\text { ( } 3^{\mathrm{a}} \text { Turma) }\end{array}$ & 24.11.98 & alienação (venda) & imóvel & após a penhora & mediato & já citado & $\operatorname{sim}$ & não & não \\
\hline
\end{tabular}


(cont. Tabela 1)

\begin{tabular}{|c|c|c|c|c|c|c|c|c|c|}
\hline Recurso & $\begin{array}{c}\text { Data do } \\
\text { julgamento }\end{array}$ & Ato & Bem & Momento processual & Terceiro & $\begin{array}{c}\text { Exige } \\
\text { citação ou } \\
\text { ciência do } \\
\text { devedor? }\end{array}$ & $\begin{array}{c}\text { Exige } \\
\text { registro ou } \\
\text { ciência do } \\
\text { terceiro? }\end{array}$ & $\begin{array}{c}\text { Fraude de } \\
\text { execução } \\
\text { reconhecida? }\end{array}$ & $\begin{array}{l}\text { Recurso } \\
\text { provido? }\end{array}$ \\
\hline $\begin{array}{c}\text { REsp 135.228-SP } \\
\text { (3 } 3^{\mathrm{a}} \text { Turma) }\end{array}$ & 02.12 .97 & alienação (venda) & imóvel & após a penhora & mediato & já citado & $\operatorname{sim}$ & não & não \\
\hline $\begin{array}{c}\text { EREsp 114.415-MG } \\
\left(2^{\mathrm{a}} \text { Seção) }\right.\end{array}$ & 12.11 .97 & alienação (venda) & imóvel & após a penhora & mediato & já citado & sim & não & $\begin{array}{c}\text { não } \\
\text { (o REsp.tb não) }\end{array}$ \\
\hline $\begin{array}{l}\text { REsp 140.670-GO } \\
\left.\text { ( } 3^{\text {a }} \text { Turma }\right)\end{array}$ & 14.10 .97 & alienação & imóvel & antes da citação & imediato & $\operatorname{sim}$ & N/A & não & sim \\
\hline $\begin{array}{l}\text { REsp 40.854-SP } \\
\quad\left(4^{\mathrm{a}} \text { Turma }\right)\end{array}$ & 12.08 .97 & alienação (venda) & imóvel & antes da penhora & imediato & já citado & sim & não & $\operatorname{sim}$ \\
\hline $\begin{array}{c}\mathrm{Ag} \operatorname{Rg} \text { no } \mathrm{Ag} 54.824-\mathrm{MG} \\
\text { (4 } 4^{\mathrm{a}} \text { Turma) }\end{array}$ & 16.12 .94 & alienação & imóvel & após a penhora & mediato & já citado & $\operatorname{sim}$ & não & não \\
\hline $\begin{array}{c}\mathrm{Ag} \mathrm{Rg} \text { no } \mathrm{Ag} 4.602-\mathrm{PR} \\
\text { (4 } \text { ( }^{\mathrm{a}} \text { Turma) }\end{array}$ & 04.03 .91 & alienação & imóvel & antes da penhora & mediato & já citado & sim & não & não \\
\hline
\end{tabular}


Apêndice 2 - Relatório da análise da jurisprudência do Superior Tribunal de Justiça sobre o tema da súmula 375

\section{1- Introdução e justificativa}

Embora já houvesse diversos artigos doutrinários e comentários de acórdãos que tratassem da jurisprudência do Superior Tribunal de Justiça quanto à relevância dada ao elemento subjetivo para a configuração da fraude de execução, até o presente momento, não havia sido feita nenhuma pesquisa científica que buscasse examinar, com rigor metodológico, tal assunto.

Assim, tendo em vista os resultados obtidos na análise dos precedentes da súmula 375, feita no Apêndice 1, supra, buscou-se verificar se as mesmas informações se repetiam em base mais ampla e mais homogênea.

Procurou-se ainda verificar que provas estariam sendo admitidas para demonstração da má-fé, o que não foi possível identificar nos precedentes da súmula, uma vez que em nenhum deles a fraude de execução havia sido reconhecida.

\section{2- Metodologia: etapas da pesquisa}

A metodologia utilizada nessa pesquisa compôs-se de duas etapas:

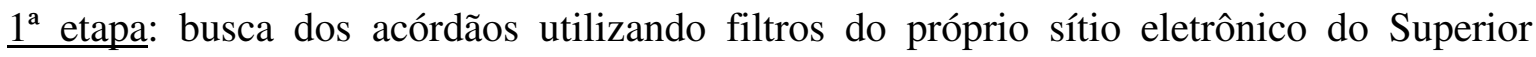
Tribunal de Justiça e triagem das ocorrências com exclusão de algumas decisões, obtendo a amostra objeto de análise na $2^{\mathrm{a}}$ etapa.

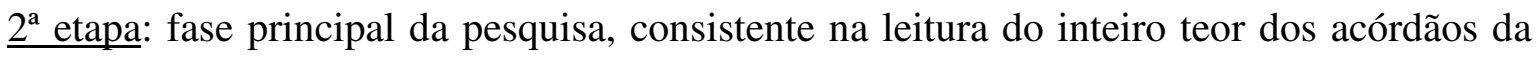
amostra obtida na $1^{\mathrm{a}}$ etapa e tabulação dos dados neles contidos de acordo com as variáveis da pesquisa, compondo o banco de dados final. 
As atividades desenvolvidas em cada uma dessas etapas e os resultados obtidos estão descritos separadamente abaixo.

2.1- Primeira etapa: coleta e triagem dos acórdãos que tratam da relevância do elemento subjetivo para configuração de fraude de execução prevista no artigo 593, II, CPC

Tendo em vista que os precedentes da súmula 375 tratavam de casos referentes às hipóteses de fraude de execução dos incisos II e III do artigo 593 do CPC e que um dos objetivos dessa pesquisa é limitar as eventuais interferências dos casos do inciso III, principalmente os relacionados às execuções fiscais, para a coleta dos acórdãos, foram utilizados, de forma concomitante, dois filtros disponíveis no próprio sítio eletrônico do Superior Tribunal de Justiça:

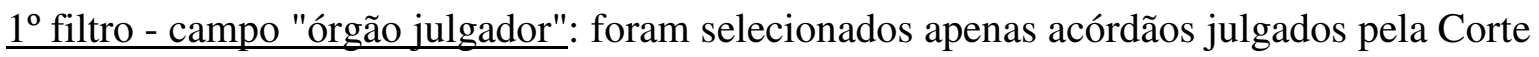
Especial, Segunda Seção e Terceira e Quarta Turmas.

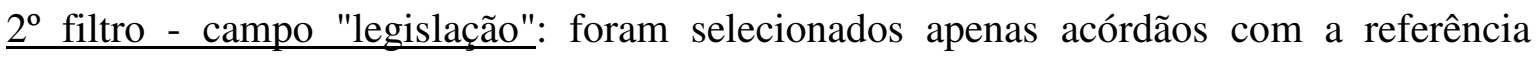
"CÓDIGO DE PROCESSO CIVIL DE 1973 (CPC-73)", "ART 593" e "INC 2".

Pelo uso concomitante desses filtros, foi obtido um universo amostral composto por 224 acórdãos, julgados por esses órgãos entre 1989 e 2008.

Em seguida, foi feita a triagem dos acórdãos, excluindo-se aqueles em que: (i) essa hipótese de fraude de execução não era o objeto do recurso; (ii) a fraude de execução não foi apreciada; (iii) o ato havia sido praticado antes do ajuizamento da ação; e (iv) o motivo do não reconhecimento da fraude de execução foi a ausência do elemento objetivo (insolvência).

Obteve-se, então, uma amostra de 152 acórdãos, sendo 2 da Corte Especial; 4 da Segunda Seção; 69 da Terceira Turma; e 77 da Quarta Turma. Tais acórdãos foram dispostos nas Tabelas 2 a 5, que seguem esse relatório, ordenados, em cada uma delas, pela data de julgamento, do mais recente para o mais remoto. 
2.2. Segunda etapa: análise e tabulação dos acórdãos

Tal como se fez em relação aos precedentes que embasaram a súmula 375 , foram verificados, em cada um dos 152 acórdãos da amostra, os seguintes elementos:

1) Coluna "Ato": identifica o tipo do ato jurídico praticado, se se tratava de alienação ou oneração de bens;

2) Coluna "Bem": identifica o tipo de bem objeto desse ato, se imóveis, veículos, linhas telefônicas etc.

3) Coluna "Momento processual": identifica o momento processual em que o ato foi praticado, dividindo-se em 4 momentos: (i) entre a propositura da ação e citação ("antes da citação"); (ii) entre a citação e a penhora ("antes da penhora"); (iii) entre a penhora e seu registro ("após a penhora"); e (iv) após o registro da penhora ("após o registro da penhora").

4) Coluna "Terceiro": identifica se o terceiro envolvido negociou diretamente com o devedor ("imediato") ou se negociou já com um terceiro ("mediato").

5) Coluna "Exige citação ou ciência do devedor?": identifica se o acórdão exigia, para a configuração da fraude de execução, a necessidade da ciência do devedor quanto à pendência da ação, seja por sua citação, seja pela existência de prova nesse sentido, a cargo do credor. Quando o ato havia sido praticado em momento processual outro que não "antes da citação", consta da planilha que o devedor já havia sido citado.

6) Coluna "Exige registro ou ciência do terceiro?": identifica se o acórdão exigia, para a configuração da fraude de execução, a necessidade de ciência do terceiro quanto à pendência da ação, seja em razão do registro da penhora, seja pela existência de prova nesse sentido, a cargo do credor. Quando a ausência de ciência do devedor foi motivo 
suficiente para o não reconhecimento da fraude de execução, consta da tabela a sigla "N/A", significando "não se aplica".

7) Coluna "Fraude de execução reconhecida?": identifica se, no caso apreciado no acórdão, a fraude de execução foi ou não reconhecida.

8) Coluna "Recurso provido?": identifica se o acórdão proveu ou não o recurso dirigido ao Superior Tribunal de Justiça.

Em todos os casos, quando o acórdão não especificava algum desses elementos, consta da tabela a sigla "N/E", significando "não especificado".

Com base nos dados obtidos, foram identificados como pertencentes ao entendimento dominante, os acórdãos que exigem a ciência tanto do devedor quanto do terceiro para a configuração da fraude de execução, seguindo o padrão dos que embasam a súmula 375.

\section{3- Resultados}

Dos 152 acórdãos analisados, 137 (ou 90,13\% do total) foram identificados como seguindo o entendimento dominante, entre eles, os 2 da Corte Especial; todos os 4 da Segunda; 55 da Terceira Turma e todos os 77 da Quarta Turma, o que confirma - como se esperava - que, embora houvesse recentes julgados em sentido divergentes da Terceira Turma (cf. RMS 24.493-RJ, j. 23.10.07 e REsp 655.000-SP, j. 23.08.07 - Tabela 4), o teor da súmula 375 representa a posição dominante da jurisprudência do Superior Tribunal de Justiça quanto ao tema.

Dos 137 acórdãos que seguem o entendimento dominante, em apenas 10 (ou 7,29\% deles) a fraude de execução foi reconhecida, sendo 3 da Terceira Turma, (REsp 186.789-PR, j. 14.12.99; REsp 116.827-RS, j. 20.05.99; e REsp 74.222-RS, j. 14.05.96); 7 da Quarta Turma (REsp 824.520-SP, j. 20.11.08; REsp 513.919-RS, j. 15.09.05; REsp 555.044-DF, j. 04.11.03; REsp 224.264-SP, j. 25.10.99; REsp 182.099-SP, j. 03.11.98; REsp 97.646-SP, j. 15.10.96) e nenhum da Corte Especial ou da Segunda Seção. 
E, desses 10 acórdãos, em apenas um houve registro da penhora. Nos outros 9, a fraude de execução só foi reconhecida mediante prova evidente da má-fé do terceiro, por documentos ou testemunhas, ou ainda, no caso de ser parente próximo do devedor (filho, irmão). O quadro abaixo permite a melhor visualização, correlacionando o recurso e a prova pela qual se considerou demonstrada a má-fé do terceiro:

\begin{tabular}{|l|l|}
\hline \multicolumn{1}{|c|}{ Recurso } & \multicolumn{1}{|c|}{ Prova da má-fé do terceiro } \\
\hline REsp 186.789-PR & registro da penhora \\
\hline REsp 116.827-RS & $\begin{array}{l}\text { publicação de edital de protesto contra alienação de bens em jornal de } \\
\text { circulação no local em que residia o terceiro }\end{array}$ \\
\hline REsp 74.222-RS & $\begin{array}{l}\text { prova nas instâncias ordinárias, de que a cadeia de alienaçães se deu } \\
\text { em "circunstâncias estranhíssimas", entre elas alienação para o } \\
\text { companheiro da devedora e que "em substância, houve apenas uma } \\
\text { alienação" }\end{array}$ \\
\hline REsp 824.520-SP & doação de pai para filha \\
\hline REsp 513.919-RS & $\begin{array}{l}\text { embora não mencione qual prova foi produzida, diz que "nas } \\
\text { instâncias ordinárias restou comprovada a má-fé" }\end{array}$ \\
\hline REsp 555.044-DF & $\begin{array}{l}\text { na escritura pública de aquisição constou terem sido apresentadas } \\
\text { certidões forenses que informavam a pendência da ação. Também } \\
\text { prova testemunhal do corretor de imóveis }\end{array}$ \\
\hline REsp 224.264-SP & doação de pai para filho \\
\hline REsp 185.138-SP & prova testemunhal da ciência dos adquirentes \\
\hline REsp 182.099-SP & doação de pai para filha \\
\hline REsp 97.646-SP & alienação entre irmãos \\
\hline
\end{tabular}

Vimos, portanto, que o entendimento dominante acaba por restringir demais a análise da fraude de execução, exigindo prova dificílima, que somente se verifica nos casos mais aberrantes. 
Tabela 2. Acórdãos da Corte Especial.

\begin{tabular}{|c|c|c|c|c|c|c|c|c|c|}
\hline Recurso & $\begin{array}{c}\text { Data do } \\
\text { julgamento }\end{array}$ & Ato & Bem & $\begin{array}{l}\text { Momento } \\
\text { processual }\end{array}$ & Terceiro & $\begin{array}{l}\text { Exige citação } \\
\text { ou ciência do } \\
\text { devedor? }\end{array}$ & $\begin{array}{l}\text { Exige registro ou } \\
\text { ciência do terceiro? }\end{array}$ & $\begin{array}{l}\text { Fraude de } \\
\text { execução } \\
\text { reconhecida? }\end{array}$ & $\begin{array}{l}\text { Recurso } \\
\text { provido? }\end{array}$ \\
\hline EREsp 259.890-SP & 02.06 .04 & $\begin{array}{l}\text { alienação (transferência } \\
\text { a título de integralização } \\
\text { de capital social) }\end{array}$ & imóvel & antes da citação & imediato & $\operatorname{sim}$ & N/A & não & não \\
\hline EREsp 101.472-RJ & 25.06 .01 & alienação (venda) & $\begin{array}{l}\text { título social } \\
\text { de clube }\end{array}$ & antes da penhora & mediato & já citado & $\operatorname{sim}$ & não & sim \\
\hline
\end{tabular}


Tabela 3. Acórdãos da Segunda Seção.

\begin{tabular}{|c|c|c|c|c|c|c|c|c|c|}
\hline Recurso & $\begin{array}{c}\text { Data do } \\
\text { julgamento }\end{array}$ & Ato & Bem & $\begin{array}{l}\text { Momento } \\
\text { processual }\end{array}$ & Terceiro & $\begin{array}{l}\text { Exige citação ou } \\
\text { ciência do } \\
\text { devedor? }\end{array}$ & $\begin{array}{c}\text { Exige registro ou } \\
\text { ciência do } \\
\text { terceiro? }\end{array}$ & $\begin{array}{l}\text { Fraude de } \\
\text { execução } \\
\text { reconhecida? }\end{array}$ & $\begin{array}{l}\text { Recurso } \\
\text { provido? }\end{array}$ \\
\hline EREsp 509.827-SP & 25.04 .07 & $\begin{array}{c}\text { alienação (compromisso } \\
\text { de compra e venda) }\end{array}$ & imóvel & antes da penhora & imediato & já citado & $\operatorname{sim}$ & não & $\begin{array}{c}\text { não } \\
\text { (o REsp. sim) }\end{array}$ \\
\hline EREsp 144.190-SP & 14.09 .05 & alienação (venda) & imóvel & antes da penhora & mediato & já citado & sim & não & $\begin{array}{c}\text { não } \\
\text { (o REsp. sim) }\end{array}$ \\
\hline REsp 442.583-MS & 27.11 .02 & alienação (venda) & imóvel & após a penhora & imediato & já citado & $\operatorname{sim}$ & não & $\operatorname{sim}$ \\
\hline EREsp 114.415-MG & 12.11 .97 & alienação (venda) & imóvel & após a penhora & mediato & já citado & $\operatorname{sim}$ & não & $\begin{array}{l}\text { não } \\
\text { (o REsp. tb } \\
\text { não) }\end{array}$ \\
\hline
\end{tabular}


Tabela 4. Acórdãos da Terceira Turma.

\begin{tabular}{|c|c|c|c|c|c|c|c|c|c|}
\hline Recurso & $\begin{array}{c}\text { Data do } \\
\text { julgamento }\end{array}$ & Ato & Bem & Momento processual & Terceiro & $\begin{array}{c}\text { Exige citação } \\
\text { ou ciência do } \\
\text { devedor? }\end{array}$ & $\begin{array}{c}\text { Exige } \\
\text { registro ou } \\
\text { ciência do } \\
\text { terceiro? }\end{array}$ & $\begin{array}{l}\text { Fraude de } \\
\text { execução } \\
\text { reconhecida? }\end{array}$ & $\begin{array}{l}\text { Recurso } \\
\text { provido? }\end{array}$ \\
\hline Ag Rg no Ag 929.630-SP & 18.12 .08 & $\begin{array}{c}\text { alienação (dação em } \\
\text { pagamento) }\end{array}$ & imóvel & apóa a penhora & imediato & já citado & sim & não & não \\
\hline RMS 24.493-RJ & 23.10 .07 & alienação (venda) & imóvel & antes da penhora & imediato & já citado & não & $\operatorname{sim}$ & não \\
\hline REsp 655.000-SP & 23.08 .07 & $\begin{array}{c}\text { alienação (dação em } \\
\text { pagamento) }\end{array}$ & imóvel & antes da penhora & imediato & já citado & não & $\operatorname{sim}$ & não \\
\hline REsp 819.198-RJ & 25.04 .06 & alienação (venda) & imóvel & antes da penhora & imediato & já citado & não & $\operatorname{sim}$ & sim \\
\hline REsp 623.775-RS & 25.10 .05 & alienação (venda) & veículo & antes da penhora & imediato & já citado & sim & não & $\operatorname{sim}$ \\
\hline REsp 255.230-RJ & 01.09 .05 & alienação (venda) & imóvel & antes da citação & imediato & sim & N/A & não & não \\
\hline REsp 648.457-MT & 04.08 .05 & alienação (venda) & imóvel & antes da penhora & mediato & já citado & $\operatorname{sim}$ & não & não \\
\hline REsp 625.235-RJ & 21.09 .04 & alienação (venda) & imóvel & antes da citação & imediato & sim & N/A & não & sim \\
\hline AgRg no REsp 625.232-RJ & 29.06 .04 & alienação (venda) & imóvel & antes da citação & imediato & $\operatorname{sim}$ & N/A & não & não \\
\hline REsp 439.418-SP & 23.09 .03 & $\begin{array}{c}\text { alienação (compromisso } \\
\text { de compra e venda) }\end{array}$ & imóvel & antes da penhora & imediato & já citado & $\operatorname{sim}$ & não & sim \\
\hline REsp 175.831-SP & 07.11 .02 & alienação fiduciária & veículo & antes da penhora & mediato & já citado & $\operatorname{sim}$ & não & $\operatorname{sim}$ \\
\hline REsp 442.778-SP & 01.10 .02 & $\begin{array}{c}\text { alienação (compromisso } \\
\text { de compra e venda) }\end{array}$ & imóvel & antes da penhora & imediato & já citado & não & sim & não \\
\hline REsp 418.109-SP & 24.06 .02 & alienação & veículo & antes da citação & imediato & $\operatorname{sim}$ & N/A & não & sim \\
\hline REsp 337.385-SP & 28.05 .02 & alienação & $\begin{array}{c}\text { linha } \\
\text { telefônica }\end{array}$ & antes da citação & imediato & sim & N/A & não & $\operatorname{sim}$ \\
\hline
\end{tabular}


(cont. Tabela 4)

\begin{tabular}{|c|c|c|c|c|c|c|c|c|c|}
\hline Recurso & $\begin{array}{c}\text { Data do } \\
\text { julgamento }\end{array}$ & Ato & Bem & Momento processual & Terceiro & $\begin{array}{c}\text { Exige citação } \\
\text { ou ciência do } \\
\text { devedor? }\end{array}$ & $\begin{array}{c}\text { Exige } \\
\text { registro ou } \\
\text { ciência do } \\
\text { terceiro? }\end{array}$ & $\begin{array}{l}\text { Fraude de } \\
\text { execução } \\
\text { reconhecida? }\end{array}$ & $\begin{array}{l}\text { Recurso } \\
\text { provido? }\end{array}$ \\
\hline REsp 351.490-SP & 21.05 .02 & oneração & imóvel & após a penhora & imediato & já citado & não & $\operatorname{sim}$ & não \\
\hline REsp 234.473-SP & 22.10 .01 & alienação (venda) & imóvel & antes da penhora & imediato & já citado & $\operatorname{sim}$ & não & não \\
\hline REsp 298.558-RJ & 12.06 .01 & alienação (venda) & imóvel & antes da penhora & mediato & já citado & $\operatorname{sim}$ & não & não \\
\hline REsp 144.200-SP & 01.03 .01 & alienação (venda) & imóvel & antes da citação & imediato & $\operatorname{sim}$ & N/A & não & não \\
\hline REsp 146.295-RS & 20.02 .01 & alienação (venda) & imóvel & antes da citação & imediato & $\operatorname{sim}$ & N/A & não & $\operatorname{sim}$ \\
\hline REsp 256.110-SP & 26.10 .00 & alienação (venda) & imóvel & após a penhora & mediato & já citado & $\operatorname{sim}$ & não & $\operatorname{sim}$ \\
\hline REsp 202.084-PR & 29.06 .00 & alienação & imóvel & antes da citação & imediato & $\operatorname{sim}$ & N/A & não & não \\
\hline REsp 225.091-GO & 29.06 .00 & alienação & imóvel & após a penhora & mediato & já citado & $\operatorname{sim}$ & não & $\operatorname{sim}$ \\
\hline REsp 245.064-MG & 15.06 .00 & alienação (venda) & imóvel & após a penhora & imediato & já citado & $\operatorname{sim}$ & não & $\operatorname{sim}$ \\
\hline REsp 226.413-SP & 08.06 .00 & alienação (venda) & imóvel & antes da citação & imediato & $\operatorname{sim}$ & não & $\operatorname{sim}$ & não \\
\hline REsp 186.789-PR & 14.12 .99 & alienação (venda) & imóvel & $\begin{array}{c}\text { após o registro da } \\
\text { penhora }\end{array}$ & mediato & já citado & $\operatorname{sim}$ & $\operatorname{sim}$ & não \\
\hline REsp 209.778-SP & 09.12 .99 & $\mathrm{n} / \mathrm{d}(11)$ & imóvel & antes da citação & $\mathrm{N} / \mathrm{E}$ & $\operatorname{sim}$ & N/A & não & $\operatorname{sim}$ \\
\hline REsp 235.639-RS & 19.11.99 & alienação (venda) & imóvel & antes da citação & imediato & $\operatorname{sim}$ & N/A & não & $\operatorname{sim}$ \\
\hline REsp 145.296-SP & 18.11 .99 & alienacão (venda) & imóvel & após a penhora & mediato & já citado & $\operatorname{sim}$ & não & $\operatorname{sim}$ \\
\hline
\end{tabular}


(cont. Tabela 4)

\begin{tabular}{|c|c|c|c|c|c|c|c|c|c|}
\hline Recurso & $\begin{array}{c}\text { Data do } \\
\text { julgamento }\end{array}$ & Ato & Bem & Momento processual & Terceiro & $\begin{array}{l}\text { Exige citação } \\
\text { ou ciência do } \\
\text { devedor? }\end{array}$ & $\begin{array}{c}\text { Exige } \\
\text { registro ou } \\
\text { ciência do } \\
\text { terceiro? }\end{array}$ & $\begin{array}{l}\text { Fraude de } \\
\text { execução } \\
\text { reconhecida? }\end{array}$ & $\begin{array}{c}\text { Recurso } \\
\text { provido? }\end{array}$ \\
\hline $\mathrm{Ag} \operatorname{Rg}$ no Ag 221.907-SP & 25.10 .99 & alienação & veículo & antes da penhora & imediato & já citado & não & $\operatorname{sim}$ & não \\
\hline REsp 166.787-SP & 10.08 .99 & alienação (venda) & imóvel & antes da penhora & mediato & já citado & sim & não & sim \\
\hline REsp 116.827-RS & 20.05 .99 & alienação & imóvel & antes da penhora & imediato & já citado & sim & sim & não \\
\hline REsp 171.917-SP & 04.03 .99 & alienação & $\mathrm{N} / \mathrm{E}$ & antes da citação & $\mathrm{N} / \mathrm{E}$ & $\operatorname{sim}$ & N/A & não & não \\
\hline REsp 123.616-SP & 24.11 .98 & alienação (venda) & imóvel & após a penhora & mediato & já citado & sim & não & não \\
\hline REsp 155.355-PE & 06.10 .98 & alienação (venda) & veículo & antes da penhora & mediato & já citado & $\operatorname{sim}$ & não & não \\
\hline REsp 153.458-MG & 04.12 .97 & alienação (venda) & veículo & antes da citação & imediato & $\operatorname{sim}$ & N/A & não & sim \\
\hline REsp 135.228-SP & 02.12 .97 & alienação (venda) & imóvel & após a penhora & mediato & já citado & sim & não & não \\
\hline REsp 103.823-SP & 23.09 .97 & alienação & imóvel & antes da citação & imediato & sim & N/A & não & sim \\
\hline REsp 113.666-DF & 13.05.97 & alienação & imóvel & após a penhora & imediato & já citado & sim & não & $\operatorname{sim}$ \\
\hline REsp 74.222-RS & 14.05 .96 & alienação (venda) & $\begin{array}{c}\text { linha } \\
\text { telefônica }\end{array}$ & antes da penhora & mediato & já citado & sim & sim & não \\
\hline REsp 60.660-PR & 17.10 .95 & alienação (venda) & imóvel & antes da penhora & imediato & já citado & sim & não & não \\
\hline REsp 65.536-SP & 14.08 .95 & alienação (venda) & imóvel & após a penhora & imediato & já citado & não & $\operatorname{sim}$ & não \\
\hline
\end{tabular}


(cont. Tabela 4)

\begin{tabular}{|c|c|c|c|c|c|c|c|c|c|}
\hline Recurso & $\begin{array}{c}\text { Data do } \\
\text { julgamento }\end{array}$ & Ato & Bem & Momento processual & Terceiro & $\begin{array}{c}\text { Exige citação } \\
\text { ou ciência do } \\
\text { devedor? }\end{array}$ & $\begin{array}{c}\text { Exige } \\
\text { registro ou } \\
\text { ciência do } \\
\text { terceiro? } \\
\end{array}$ & $\begin{array}{l}\text { Fraude de } \\
\text { execução } \\
\text { reconhecida? }\end{array}$ & $\begin{array}{l}\text { Recurso } \\
\text { provido? }\end{array}$ \\
\hline REsp 61.114-MG & 29.05 .95 & alienação (venda) & $\begin{array}{l}\text { linha } \\
\text { telefônica }\end{array}$ & antes da penhora & mediato & já citado & não & $\operatorname{sim}$ & $\operatorname{sim}$ \\
\hline REsp 53.756-SP & 25.10 .94 & $\begin{array}{l}\text { alienação (compromisso } \\
\text { de compra e venda) }\end{array}$ & imóvel & antes da citação & imediato & $\operatorname{sim}$ & N/A & não & $\operatorname{sim}$ \\
\hline REsp 47.806-RJ & 02.08 .94 & alienação (venda) & imóvel & após a penhora & imediato & já citado & $\operatorname{sim}$ & não & não \\
\hline REsp 40.739-SP & 19.04 .94 & $\begin{array}{l}\text { alienação (compromisso } \\
\text { de compra e venda) }\end{array}$ & imóvel & antes da citação & imediato & $\operatorname{sim}$ & N/A & não & $\operatorname{sim}$ \\
\hline REsp 40.620-SP & 24.02 .94 & alienação (venda) & imóvel & antes da citação & mediato & $\operatorname{sim}$ & N/A & não & $\operatorname{sim}$ \\
\hline REsp 3.259-RS & 22.02 .94 & $\begin{array}{c}\text { alienação (dação em } \\
\text { pagamento) }\end{array}$ & imóvel & após a penhora & imediato & já citado & $\operatorname{sim}$ & não & não \\
\hline REsp 38.012-PR & 29.11 .93 & alienação & $\begin{array}{l}\text { linha } \\
\text { telefônica }\end{array}$ & antes da citação & imediato & $\operatorname{sim}$ & N/A & não & $\operatorname{sim}$ \\
\hline REsp 38.239-SP & 05.10 .93 & alienação & imóvel & antes da penhora & imediato & já citado & não & $\operatorname{sim}$ & não \\
\hline REsp 36.039-RJ & 29.09 .93 & alienação (venda) & $\begin{array}{c}\text { linha } \\
\text { telefônica }\end{array}$ & antes da citação & imediato & $\operatorname{sim}$ & N/A & não & $\operatorname{sim}$ \\
\hline REsp 30.599-RJ & 29.06 .93 & alienação (venda) & imóvel & antes da citação & mediato & $\operatorname{sim}$ & N/A & não & $\operatorname{sim}$ \\
\hline REsp 19.114-SP & 10.05 .93 & alienação (venda) & imóvel & antes da penhora & imediato & já citado & $\operatorname{sim}$ & não & $\operatorname{sim}$ \\
\hline REsp 23.507-SP & 26.04 .93 & alienação (doação) & imóvel & antes da penhora & imediato & já citado & não & $\operatorname{sim}$ & não \\
\hline REsp 29.138-SP & 30.03 .93 & $\begin{array}{c}\text { alienação (dação em } \\
\text { pagamento) }\end{array}$ & imóvel & antes da citação & imediato & $\operatorname{sim}$ & N/A & não & $\operatorname{sim}$ \\
\hline Ag Rg no Ag 30.018-RJ & 09.03 .93 & alienação & imóvel & antes da citação & imediato & $\operatorname{sim}$ & N/A & não & não \\
\hline
\end{tabular}


(cont. Tabela 4)

\begin{tabular}{|c|c|c|c|c|c|c|c|c|c|}
\hline Recurso & $\begin{array}{c}\text { Data do } \\
\text { julgamento }\end{array}$ & Ato & Bem & Momento processual & Terceiro & $\begin{array}{l}\text { Exige citação } \\
\text { ou ciência do } \\
\text { devedor? }\end{array}$ & $\begin{array}{c}\text { Exige } \\
\text { registro ou } \\
\text { ciência do } \\
\text { terceiro? } \\
\end{array}$ & $\begin{array}{l}\text { Fraude de } \\
\text { execução } \\
\text { reconhecida? }\end{array}$ & $\begin{array}{l}\text { Recurso } \\
\text { provido? }\end{array}$ \\
\hline REsp 22.330-MG & 16.12 .92 & $\begin{array}{l}\text { alienação (compromisso } \\
\text { de compra e venda) }\end{array}$ & imóvel & antes da citação & imediato & $\operatorname{sim}$ & N/A & não & $\operatorname{sim}$ \\
\hline REsp 23.355-RJ & 10.08 .92 & alienação (venda) & $\begin{array}{l}\text { linha } \\
\text { telefônica }\end{array}$ & antes da citação & imediato & $\operatorname{sim}$ & N/A & não & não \\
\hline REsp 15.641-SP & 25.02.92 & alienação (venda) & imóvel & antes da citação & imediato & $\operatorname{sim}$ & N/A & não & não \\
\hline REsp 15.841-MG & 24.02.92 & alienação (venda) & imóvel & antes da citação & imediato & $\operatorname{sim}$ & não & $\operatorname{sim}$ & $\operatorname{sim}$ \\
\hline REsp 11.178-SP & 13.08 .91 & alienação & $\mathrm{N} / \mathrm{E}$ & antes da citação & imediato & $\operatorname{sim}$ & N/A & não & $\operatorname{sim}$ \\
\hline REsp 8.548-SP & 21.05.91 & alienação (venda) & imóvel & antes da citação & imediato & $\operatorname{sim}$ & N/A & não & $\operatorname{sim}$ \\
\hline $\mathrm{Ag} \operatorname{Rg}$ no Ag 9.500-SP & 21.05 .91 & alienação (venda) & imóvel & após a penhora & mediato & já citado & $\operatorname{sim}$ & não & não \\
\hline REsp 7.712-RS & 09.04 .91 & $\begin{array}{c}\text { alienação (dação em } \\
\text { pagamento) }\end{array}$ & imóvel & após a penhora & imediato & já citado & não & $\operatorname{sim}$ & $\operatorname{sim}$ \\
\hline REsp 7.429-PR & 12.03 .91 & alienação (venda) & imóvel & antes da citação & imediato & $\operatorname{sim}$ & N/A & não & não \\
\hline REsp 6.189-SP & 04.12 .90 & alienação (venda) & imóvel & antes da citação & imediato & $\operatorname{sim}$ & não & $\operatorname{sim}$ & não \\
\hline REsp 5.208-SP & 29.10 .90 & alienação & imóvel & antes da citação & imediato & $\operatorname{sim}$ & N/A & não & não \\
\hline REsp 2.653-MS & 18.09 .90 & alienação (venda) & imóvel & antes da citação & mediato & $\operatorname{sim}$ & N/A & não & $\operatorname{sim}$ \\
\hline REsp 2.053-MS & 21.08 .90 & alienação (venda) & imóvel & antes da citação & imediato & $\operatorname{sim}$ & N/A & não & não \\
\hline REsp 2.597-RS & 29.06 .90 & alienação (venda) & imóvel & após a penhora & imediato & já citado & não & $\operatorname{sim}$ & sim \\
\hline
\end{tabular}


Tabela 5. Acórdãos da Quarta Turma.

\begin{tabular}{|c|c|c|c|c|c|c|c|c|c|}
\hline Recurso & $\begin{array}{l}\text { Data do } \\
\text { julgamento }\end{array}$ & Ato & Bem & Momento processual & Terceiro & $\begin{array}{l}\text { Exige citação ou } \\
\text { ciência do } \\
\text { devedor? }\end{array}$ & $\begin{array}{c}\text { Exige } \\
\text { registro ou } \\
\text { ciência do } \\
\text { terceiro? }\end{array}$ & $\begin{array}{l}\text { Fraude de } \\
\text { execução } \\
\text { reconhecida? }\end{array}$ & $\begin{array}{l}\text { Recurso } \\
\text { provido? }\end{array}$ \\
\hline REsp 824.520-SP & 20.11 .08 & alienação (doação) & imóvel & antes da citação & imediato & $\operatorname{sim}$ & $\operatorname{sim}$ & $\operatorname{sim}$ & não \\
\hline REsp 170.430-SP & 28.08 .07 & alienação (venda) & imóvel & após a penhora & mediato & já citado & $\operatorname{sim}$ & não & $\operatorname{sim}$ \\
\hline REsp 943.591-PR & 19.06.07 & alienação & imóvel & antes da penhora & mediato & já citado & $\operatorname{sim}$ & não & não \\
\hline REsp 784.995-MT & 14.11.06 & alienação (venda) & veículo & antes da penhora & imediato & já citado & $\operatorname{sim}$ & não & $\operatorname{sim}$ \\
\hline REsp 513.919-RS & 15.09 .05 & alienação (venda) & imóvel & após a penhora & imediato & já citado & $\operatorname{sim}$ & sim & não \\
\hline Ag Rg no Ag 658.180-GO & 23.08 .05 & alienação (venda) & imóvel & antes da penhora & imediato & já citado & $\operatorname{sim}$ & não & não \\
\hline REsp 50.878-RJ & 19.04 .05 & alienação (venda) & linha telefônica & após a penhora & mediato & já citado & $\operatorname{sim}$ & não & não \\
\hline REsp 618.444-SC & 07.04 .05 & alienação (venda) & veículo & após a penhora & mediato & já citado & $\operatorname{sim}$ & não & não \\
\hline REsp 432.185-SP & 03.03 .05 & alienação (venda) & imóvel & após a penhora & imediato & já citado & $\operatorname{sim}$ & não & sim \\
\hline Ag Rg no Ag 540.193-PR & 02.09 .04 & $\begin{array}{l}\text { alienação (compromisso de } \\
\text { compra e venda) }\end{array}$ & imóvel & após a penhora & $\mathrm{N} / \mathrm{E}$ & já citado & sim & não & não \\
\hline REsp 555.044-DF & 04.11 .03 & alienação & imóvel & antes da penhora & imediato & já citado & $\operatorname{sim}$ & $\operatorname{sim}$ & não \\
\hline REsp 448.120-MT & 21.10 .03 & $\begin{array}{c}\text { alienação (compromisso de } \\
\text { compra e venda) }\end{array}$ & imóvel & antes da citação & mediato & $\operatorname{sim}$ & N/A & não & não \\
\hline REsp 532.946-PR & 21.08 .03 & alienação & imóvel & antes da penhora & imediato & já citado & $\operatorname{sim}$ & não & não \\
\hline
\end{tabular}


(cont. Tabela 5)

\begin{tabular}{|c|c|c|c|c|c|c|c|c|c|}
\hline Recurso & $\begin{array}{c}\text { Data do } \\
\text { julgamento }\end{array}$ & Ato & Bem & Momento processual & Terceiro & $\begin{array}{c}\text { Exige citação ou } \\
\text { ciência do } \\
\text { devedor? }\end{array}$ & $\begin{array}{c}\text { Exige } \\
\text { registro ou } \\
\text { ciência do } \\
\text { terceiro? }\end{array}$ & $\begin{array}{c}\text { Fraude de } \\
\text { execução } \\
\text { reconhecida? }\end{array}$ & $\begin{array}{l}\text { Recurso } \\
\text { provido? }\end{array}$ \\
\hline REsp 489.346-MG & 06.05 .03 & alienação & imóvel & antes da penhora & imediato & já citado & $\operatorname{sim}$ & não & sim \\
\hline Ag Rg no Ag 389.569-MG & 27.08 .02 & alienação (venda) & veículo & antes da penhora & imediato & já citado & $\operatorname{sim}$ & não & não \\
\hline REsp 182.760-SP & 27.06 .02 & $\begin{array}{c}\text { alienação (dação em } \\
\text { pagamento) }\end{array}$ & imóvel & antes da penhora & imediato & já citado & $\operatorname{sim}$ & não & $\operatorname{sim}$ \\
\hline REsp 316.301-SP & 27.06 .02 & alienação & imóvel & antes da citação & imediato & $\operatorname{sim}$ & N/A & não & sim \\
\hline REsp 316.244-SP & 27.06 .02 & oneração (hipoteca) & imóvel & antes da citação & imediato & $\operatorname{sim}$ & N/A & não & $\operatorname{sim}$ \\
\hline REsp 200.262-SP & 25.06 .02 & alienação & imóvel & antes da penhora & imediato & já citado & $\operatorname{sim}$ & não & $\operatorname{sim}$ \\
\hline REsp 235.201-SP & 25.06 .02 & alienação & imóvel & antes da penhora & mediato & já citado & $\operatorname{sim}$ & não & $\operatorname{sim}$ \\
\hline REsp 351.807-SP & 04.06 .02 & $\begin{array}{l}\text { alienação (compromisso de } \\
\text { compra e venda) }\end{array}$ & imóvel & após a penhora & imediato & já citado & $\operatorname{sim}$ & não & $\operatorname{sim}$ \\
\hline REsp 253.707-PR & 14.05 .02 & alienação (venda) & veículo & antes da citação & imediato & $\operatorname{sim}$ & N/A & não & $\operatorname{sim}$ \\
\hline REsp 254.554-SP & 27.11 .01 & alienação (venda) & imóvel & antes da penhora & imediato & já citado & $\operatorname{sim}$ & não & $\operatorname{sim}$ \\
\hline REsp 302.959-DF & 26.06 .01 & alienação (venda) & imóvel & antes da citação & imediato & $\operatorname{sim}$ & N/A & não & $\operatorname{sim}$ \\
\hline REsp 103.719-SP & 13.02.01 & alienação (venda) & imóvel & após a penhora & mediato & já citado & $\operatorname{sim}$ & não & não \\
\hline REsp 39.887-SP & 19.10 .00 & alienação (venda) & imóvel & após a penhora & mediato & já citado & sim & não & $\operatorname{sim}$ \\
\hline
\end{tabular}


(cont. Tabela 5)

\begin{tabular}{|c|c|c|c|c|c|c|c|c|c|}
\hline Recurso & $\begin{array}{c}\text { Data do } \\
\text { julgamento }\end{array}$ & Ato & Bem & Momento processual & Terceiro & $\begin{array}{c}\text { Exige citação ou } \\
\text { ciência do } \\
\text { devedor? }\end{array}$ & $\begin{array}{c}\text { Exige } \\
\text { registro ou } \\
\text { ciência do } \\
\text { terceiro? } \\
\end{array}$ & $\begin{array}{c}\text { Fraude de } \\
\text { execução } \\
\text { reconhecida? }\end{array}$ & $\begin{array}{l}\text { Recurso } \\
\text { provido? }\end{array}$ \\
\hline REsp 268.259-SP & 17.10 .00 & $\begin{array}{c}\text { alienação (dação em } \\
\text { pagamento) }\end{array}$ & imóvel & antes da citação & imediato & $\operatorname{sim}$ & N/A & não & sim \\
\hline REsp 257.331-SP & 05.10 .00 & alienação (venda) & imóvel & antes da citação & mediato & $\operatorname{sim}$ & N/A & não & sim \\
\hline REsp 189.720-PE & 15.08 .00 & alienação & linha telefônica & antes da citação & imediato & $\operatorname{sim}$ & N/A & não & não \\
\hline REsp 221.720-SP & 15.08 .00 & alienação & linha telefônica & antes da citação & imediato & $\operatorname{sim}$ & N/A & não & sim \\
\hline REsp 131.587-RJ & 18.05 .00 & alienação & imóvel & após a penhora & mediato & já citado & sim & não & não \\
\hline REsp 248.323-SP & 04.05 .00 & alienação (venda) & imóvel & antes da penhora & mediato & já citado & $\operatorname{sim}$ & não & $\operatorname{sim}$ \\
\hline REsp 246.625-MG & 04.05 .00 & alienação (venda) & imóvel & antes da penhora & mediato & já citado & $\operatorname{sim}$ & não & $\operatorname{sim}$ \\
\hline REsp 110.336-PR & 16.03 .00 & alienação (venda) & imóvel & após a penhora & mediato & já citado & $\operatorname{sim}$ & não & sim \\
\hline REsp 232.548-SP & 14.12 .99 & alienação (venda) & imóvel & antes da citação & imediato & sim & N/A & não & $\operatorname{sim}$ \\
\hline REsp 235.267-SP & 14.12 .99 & alienação (venda) & imóvel & antes da penhora & imediato & já citado & $\operatorname{sim}$ & não & não \\
\hline REsp 212.107-SP & 04.11 .99 & alienação (venda) & imóvel & antes da citação & imediato & sim & N/A & não & sim \\
\hline REsp 224.264-SP & 25.10 .99 & alienação (doação) & imóvel & antes da penhora & imediato & já citado & sim & $\operatorname{sim}$ & não \\
\hline REsp 214.990-SP & 02.09 .99 & alienação (venda) & imóvel & após a penhora & imediato & já citado & $\operatorname{sim}$ & não & $\operatorname{sim}$ \\
\hline
\end{tabular}


(cont. Tabela 5)

\begin{tabular}{|c|c|c|c|c|c|c|c|c|c|}
\hline Recurso & $\begin{array}{c}\text { Data do } \\
\text { julgamento }\end{array}$ & Ato & Bem & Momento processual & Terceiro & $\begin{array}{l}\text { Exige citação ou } \\
\text { ciência do } \\
\text { devedor? }\end{array}$ & $\begin{array}{c}\text { Exige } \\
\text { registro ou } \\
\text { ciência do } \\
\text { terceiro? } \\
\end{array}$ & $\begin{array}{c}\text { Fraude de } \\
\text { execução } \\
\text { reconhecida? }\end{array}$ & $\begin{array}{l}\text { Recurso } \\
\text { provido? }\end{array}$ \\
\hline REsp 215.306-MG & 10.08 .99 & $\begin{array}{l}\text { alienação (dação em } \\
\text { pagamento) }\end{array}$ & imóvel & após a penhora & imediato & já citado & $\operatorname{sim}$ & não & sim \\
\hline REsp 185.138-SP & 20.05 .99 & alienação (venda) & imóvel & antes da penhora & mediato & já citado & sim & $\operatorname{sim}$ & não \\
\hline REsp 185.813-MG & 05.11 .98 & alienação (venda) & imóvel & antes da penhora & mediato & já citado & $\operatorname{sim}$ & não & sim \\
\hline REsp 182.099-SP & 03.11 .98 & alienação (doação) & imóvel & $\begin{array}{l}\text { após o registro da } \\
\text { penhora }\end{array}$ & imediato & já citado & $\operatorname{sim}$ & $\operatorname{sim}$ & sim \\
\hline REsp 172.354-SP & 01.09 .98 & $\begin{array}{l}\text { alienação (integralização de } \\
\text { capital social) }\end{array}$ & imóvel & antes da citação & imediato & sim & N/A & não & sim \\
\hline REsp 166.322-SP & 07.05 .98 & alienação & linha telefônica & antes da citação & imediato & $\operatorname{sim}$ & N/A & não & $\operatorname{sim}$ \\
\hline REsp 77.161-SP & 19.02 .98 & alienação (venda) & imóvel & antes da penhora & mediato & já citado & $\operatorname{sim}$ & não & não \\
\hline REsp 145.371-MG & 14.10 .97 & alienação (venda) & imóvel & após a penhora & imediato & já citado & $\operatorname{sim}$ & não & sim \\
\hline REsp 136.342-PR & 14.10.97 & alienação & imóvel & após a penhora & mediato & já citado & sim & não & sim \\
\hline REsp 40.854-SP & 12.08 .97 & alienação (venda) & imóvel & antes da penhora & imediato & já citado & sim & não & sim \\
\hline REsp 113.871-DF & 12.05 .97 & alienação (venda) & imóvel & antes da penhora & imediato & já citado & $\operatorname{sim}$ & não & sim \\
\hline REsp 114.415-MG & 23.04.97 & alienação (venda) & imóvel & após a penhora & mediato & já citado & $\operatorname{sim}$ & não & não \\
\hline REsp 49.780-RS & 23.04 .97 & $\begin{array}{l}\text { alienação (compromisso de } \\
\text { compra e venda) }\end{array}$ & imóvel & após a penhora & imediato & já citado & $\operatorname{sim}$ & não & não \\
\hline
\end{tabular}


(cont. Tabela 5)

\begin{tabular}{|c|c|c|c|c|c|c|c|c|c|}
\hline Recurso & $\begin{array}{c}\text { Data do } \\
\text { julgamento }\end{array}$ & Ato & Bem & Momento processual & Terceiro & $\begin{array}{l}\text { Exige citação ou } \\
\text { ciência do } \\
\text { devedor? }\end{array}$ & $\begin{array}{c}\text { Exige } \\
\text { registro ou } \\
\text { ciência do } \\
\text { terceiro? } \\
\end{array}$ & $\begin{array}{l}\text { Fraude de } \\
\text { execução } \\
\text { reconhecida? }\end{array}$ & $\begin{array}{l}\text { Recurso } \\
\text { provido? }\end{array}$ \\
\hline REsp 56.056-RS & 04.02 .97 & alienação (venda) & imóvel & após a penhora & $\mathrm{N} / \mathrm{E}$ & já citado & $\operatorname{sim}$ & não & não \\
\hline REsp 108.774-PR & 04.02 .97 & alienação & imóvel & antes da citação & imediato & sim & N/A & não & não \\
\hline REsp 97.646-SP & 15.10 .96 & alienação (venda) & imóvel & antes da penhora & imediato & já citado & $\operatorname{sim}$ & $\operatorname{sim}$ & não \\
\hline REsp 35.342-MG & 15.10 .96 & alienação (venda) & imóvel & antes da citação & imediato & $\operatorname{sim}$ & N/A & não & $\operatorname{sim}$ \\
\hline REsp 42.005-SP & 24.09 .96 & alienação & linha telefônica & antes da penhora & imediato & já citado & $\operatorname{sim}$ & não & não \\
\hline REsp 37.931-RJ & 16.04 .96 & alienação & imóvel & antes da citação & imediato & $\operatorname{sim}$ & N/A & não & não \\
\hline REsp 76.063-RS & 08.04 .96 & $\begin{array}{c}\text { alienação (dação em } \\
\text { pagamento) }\end{array}$ & imóvel & antes da citação & mediato & sim & N/A & não & não \\
\hline REsp 62.732-SP & 27.11 .95 & alienação (venda) & imóvel & antes da citação & imediato & sim & N/A & não & sim \\
\hline $\mathrm{Ag} \operatorname{Rg}$ no $\mathrm{Ag}$ & 24.05 .94 & alienação & imóvel & antes da citação & imediato & sim & N/A & não & não \\
\hline REsp 45.519-SP & 12.04 .94 & alienação (venda) & imóvel & antes da citação & imediato & $\operatorname{sim}$ & N/A & não & não \\
\hline REsp 45.170-SP & 12.04 .94 & alienação & linha telefônica & antes da citação & imediato & $\operatorname{sim}$ & N/A & não & sim \\
\hline REsp 40.306-SP & 30.11 .93 & alienação & imóvel & antes da citação & imediato & sim & N/A & não & não \\
\hline REsp 37.011-SP & 14.09 .93 & alienação (venda) & imóvel & após a penhora & mediato & já citado & $\operatorname{sim}$ & não & $\operatorname{sim}$ \\
\hline
\end{tabular}


(cont. Tabela 5)

\begin{tabular}{|c|c|c|c|c|c|c|c|c|c|}
\hline Recurso & $\begin{array}{c}\text { Data do } \\
\text { julgamento }\end{array}$ & Ato & Bem & Momento processual & Terceiro & $\begin{array}{l}\text { Exige citação ou } \\
\text { ciência do } \\
\text { devedor? }\end{array}$ & $\begin{array}{c}\text { Exige } \\
\text { registro ou } \\
\text { ciência do } \\
\text { terceiro? } \\
\end{array}$ & $\begin{array}{l}\text { Fraude de } \\
\text { execução } \\
\text { reconhecida? }\end{array}$ & $\begin{array}{l}\text { Recurso } \\
\text { provido? }\end{array}$ \\
\hline REsp 13.352-RJ & 24.11 .92 & alienação (doação) & imóvel & antes da citação & imediato & $\operatorname{sim}$ & N/A & não & sim \\
\hline REsp 16.823-SP & 16.11 .92 & alienação (doação) & imóvel & antes da citação & imediato & sim & N/A & não & sim \\
\hline REsp 27.431-SP & 10.11 .92 & alienação (venda) & imóvel & antes da citação & imediato & $\operatorname{sim}$ & N/A & não & não \\
\hline REsp 10.520-PR & 14.09 .92 & $\begin{array}{c}\text { alienação (cessão e } \\
\text { transferência de direitos) }\end{array}$ & imóvel & antes da citação & imediato & $\operatorname{sim}$ & N/A & não & não \\
\hline REsp 4755-SP & 30.06 .92 & alienação & imóvel & antes da citação & imediato & $\operatorname{sim}$ & N/A & não & não \\
\hline REsp 4.132-RS & 02.10 .91 & alienação (venda) & sim (imóvel) & antes da penhora & imediato & já citado & $\operatorname{sim}$ & não & não \\
\hline $\mathrm{Ag} \operatorname{Rg}$ no Ag 5351-SP & 06.11 .90 & $\begin{array}{l}\text { alienação (compromisso de } \\
\text { compra e venda) }\end{array}$ & sim (imóvel) & antes da citação & imediato & sim & N/A & não & não \\
\hline REsp 3.771-GO & 16.10 .90 & alienação & sim (imóvel) & antes da penhora & imediato & já citado & $\operatorname{sim}$ & não & não \\
\hline REsp 2.429-SP & 19.06 .90 & $\begin{array}{l}\text { alienação (dação em } \\
\text { pagamento) }\end{array}$ & sim (imóvel) & antes da citação & imediato & sim & N/A & não & não \\
\hline REsp 2.573-RS & 14.05 .90 & alienação (venda) & sim (imóvel) & antes da citação & imediato & sim & N/A & não & não \\
\hline $\mathrm{Ag} \operatorname{Rg}$ no ag 2.761-SP & 24.04 .90 & alienação (venda) & sim (imóvel) & antes da citação & imediato & sim & N/A & não & não \\
\hline Ag Rg no Ag 272-SP & 17.04 .90 & alienação (venda) & sim (imóvel) & antes da citação & imediato & sim & N/A & não & não \\
\hline
\end{tabular}




\section{Apêndice 3 - Figuras}
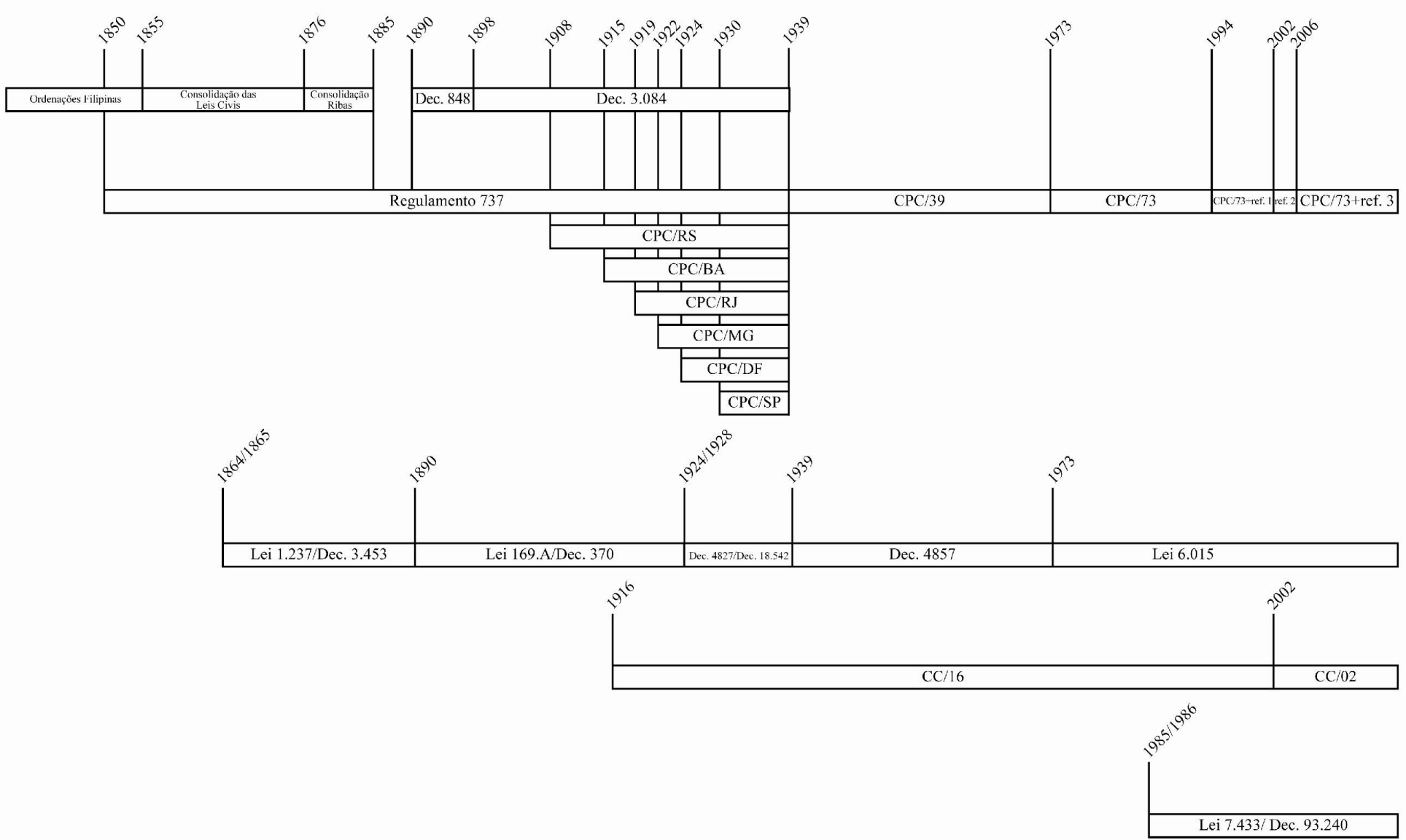

Figura 1. Linha do tempo da legislação aplicável ao objeto desta tese. 

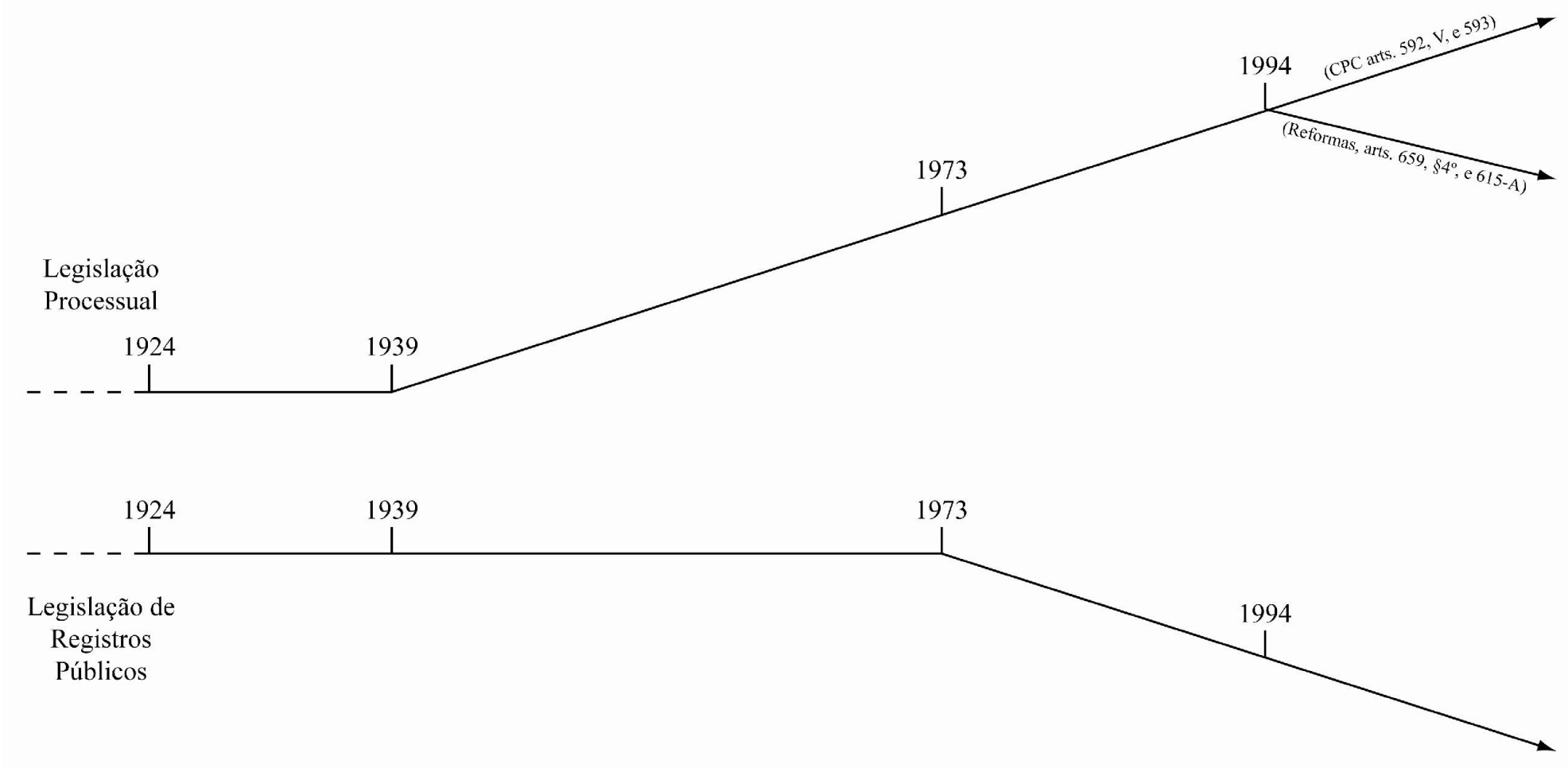

Figura 2. Vetores das alterações na legislação processual e registrária - a quebra do paralelismo. 

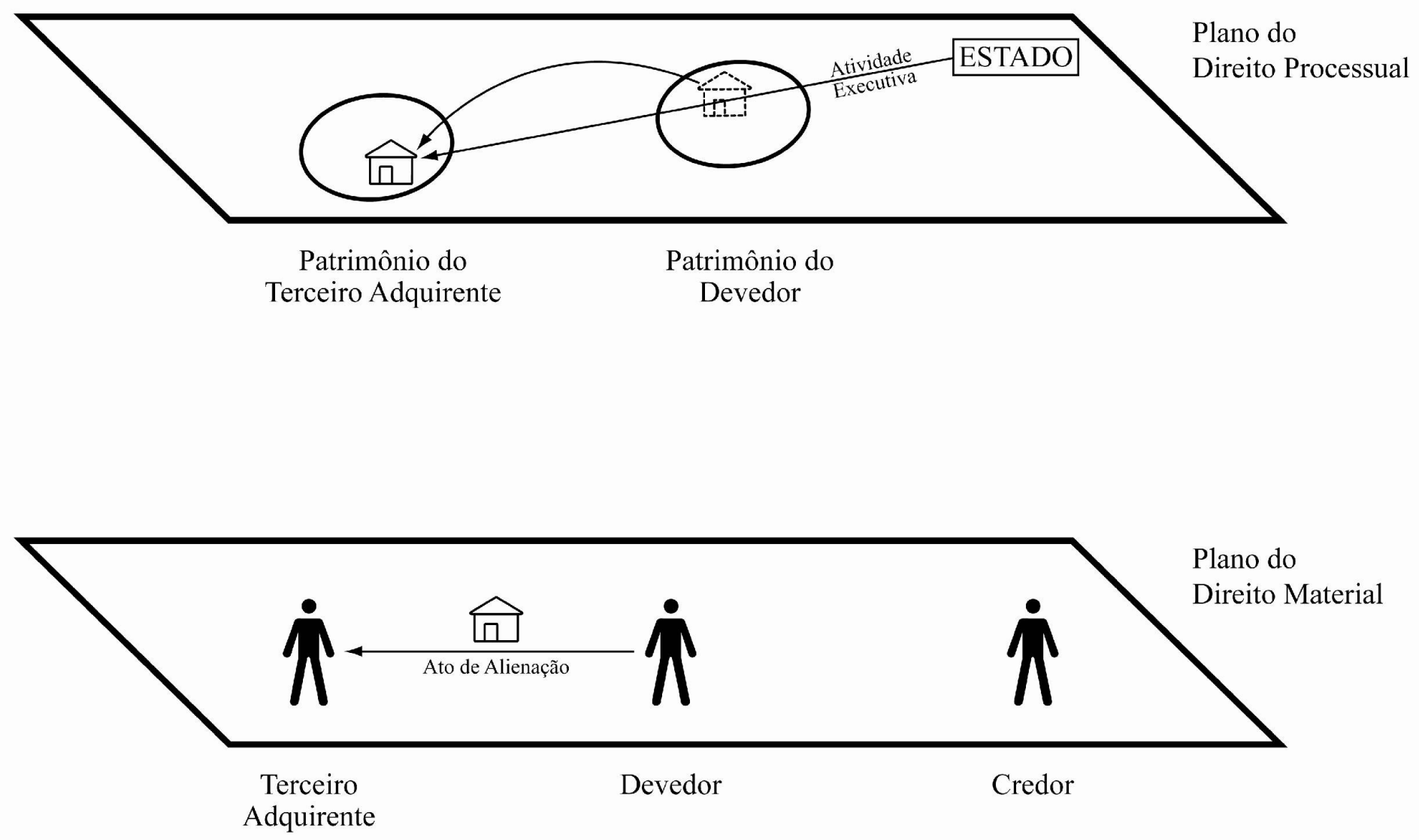

Figura 3. Ilustração dos planos de direito material e processual. 


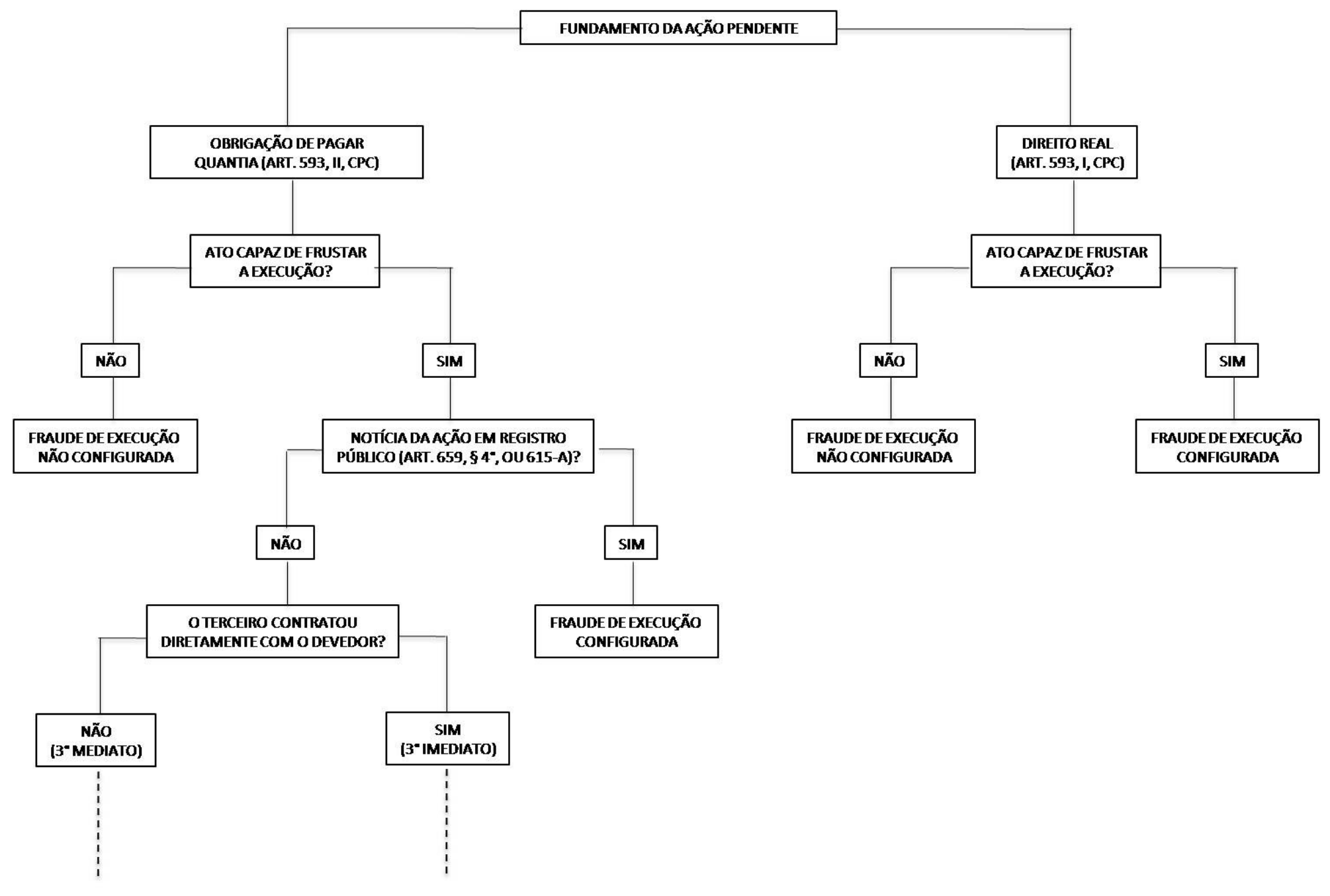

Figura 4. Fluxograma da metodologia proposta no capítulo 7. 
(cont. Figura 4)

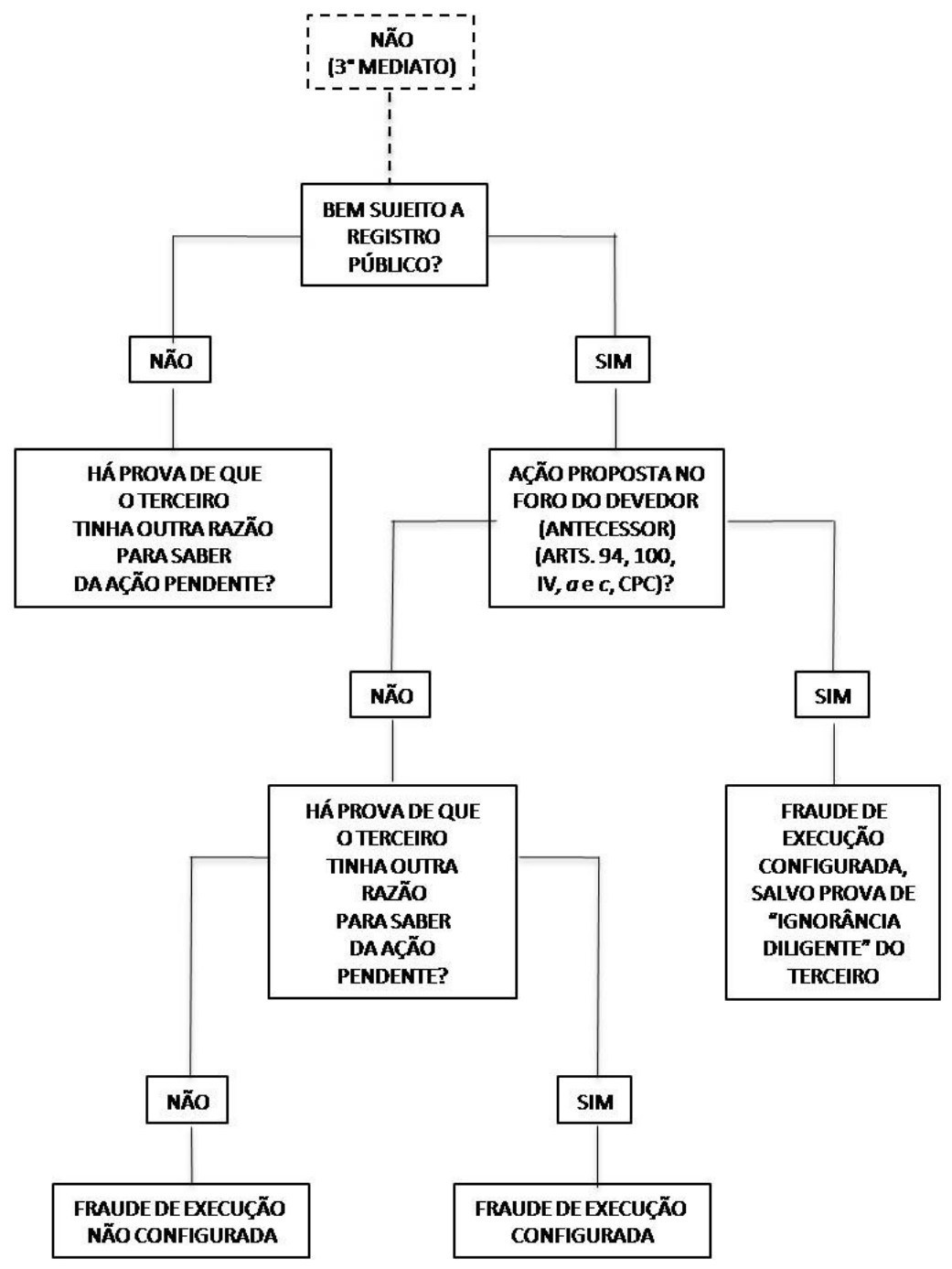

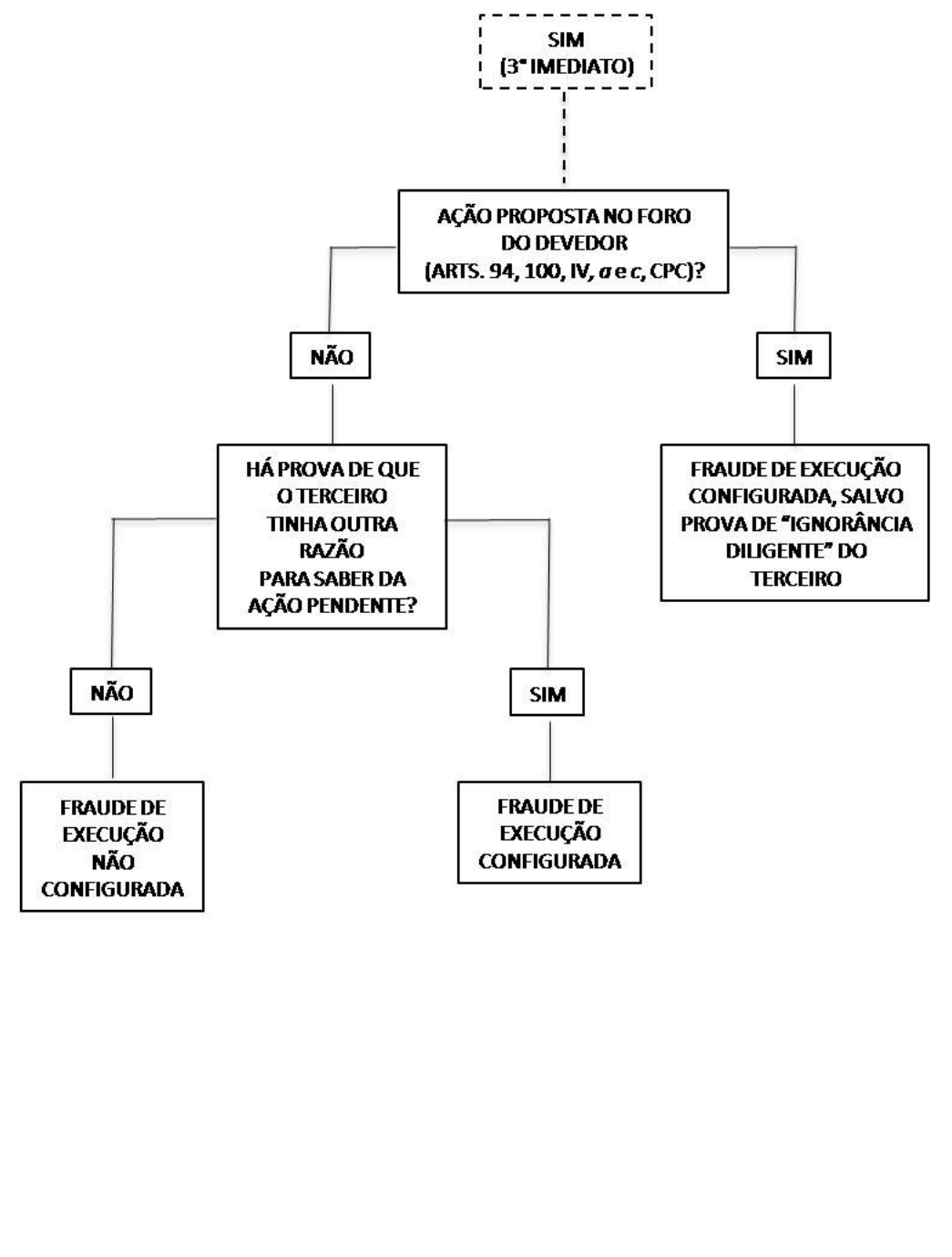




\section{Apêndice 4 - Propostas de alterações legislativas}

Art. 263. Considera-se proposta a ação, tanto que a petição inicial seja despachada pelo juiz, ou simplesmente distribuída, onde houver mais de uma vara. A propositura da ação, todavia, só produz, quanto ao réu, os efeitos mencionados no art. 219 depois que for validamente citado.

$\S 1^{\circ} \mathrm{O}$ autor poderá, no ato da distribuição, obter certidão comprobatória do ajuizamento da ação condenatória ou da execução, com identificação das partes e valor da causa, para fins de averbação no registro de imóveis, registro de veículos ou registro de outros bens sujeitos a penhora ou arresto.

$\S 2^{\circ}$ Perde a eficácia a averbação prevista no parágrafo anterior, se, no prazo de 60 (sessenta) meses a contar da sua efetivação, não for averbada a penhora ou deferida sua prorrogação.

$\S 3^{\circ}$ Pode o interessado requerer ao juiz da causa o cancelamento da averbação nos casos de excesso ou sua substituição por outro bem.

Art. 593. Considera-se em fraude de execução a alienação ou oneração de bens:

I- quando sobre eles pender ação fundada em direito real;

II- quando o terceiro tem razão para saber que os bens são objeto de penhora, arresto, ou sequestro em ação pendente;

III- quando o terceiro tem razão para saber da pendência de ação que possa reduzir o devedor à insolvência;

$\S 1^{\circ}$ A averbação dos atos de constrição ou do ajuizamento da ação, previstos nos incisos II e III do caput, nos registros públicos de imóveis, veículos ou de outros bens sujeitos a registro, geram presunção absoluta de seu conhecimento por terceiros;

$\S 2^{\circ} \mathrm{O}$ registro das ações mencionadas nos incisos II e III do caput nos cartórios distribuidores do foro do domicílio do devedor gera presunção relativa de que o terceiro tem razão para saber da pendência dessas ações;

$\S 3^{\circ}$ Em se tratando de bens sujeitos a registro público, a presunção relativa prevista no parágrafo anterior decorre também do registro das ações mencionadas nos incisos II e III do caput nos cartórios distribuidores do foro do domicílio dos antecessores do devedor constante do registro público e do foro da situação do bem, se for imóvel.

Art. 659 A penhora deverá incidir em tantos bens quantos bastem para o pagamento do principal atualizado, juros custas e honorários advocatícios. (...) 
$\S 4^{\circ}$ A penhora de bens imóveis realizar-se-á mediante auto ou termo de penhora, cabendo ao exeqüente, sem prejuízo da imediata intimação do executado (art. 652, $\S 4^{\circ}$ ), providenciar, para presunção absoluta da possibilidade de conhecimento por terceiros, a respectiva averbação no ofício imobiliário, registro de veículos ou outros registros públicos mediante a apresentação de certidão de inteiro teor do ato, independentemente de mandado judicial. (...)

$\S 6^{\circ}$ Obedecidas as normas de segurança que forem instituídas, sob critérios uniformes, pelos Tribunais, a penhora de numerário e as averbações de penhoras de bens imóveis e móveis podem ser realizadas por meios eletrônicos. 


\section{ÍNDICE DE FONTES}

FONTES JURÍDICAS ANTIGAS

CORPUS IURIS CIVILIS

Digesta

D. $42,8,1 \mathrm{pr}$.

D. $42,8,10 p r$.

FONTES JURÍDICAS INTERMÉDIAS

Ordenações Afonsinas

Ord. Afons. 3, 91

Ordenações Filipinas

Ord. Filip. 3, 84, 14

Ord. Filip. 3, 86, 1

Ord. Filip. 3, 86, 13

Ord. Filip. 3, 86, 15

Ord. Filip. 3, 86, 16

Ord. Filip. 3, 86, 17

Ord. Filip. 4, 10, 3

Ord. Filip. 4, 10, 4

Ord. Filip. 4, 10, 7

Ord. Filip. 4, 10, 9

Ordenações Manuelinas

Ord. Manuel. 3, 71

FONTES JURÍDICAS MODERNAS

\section{Alemanha}

$Z P O$

$\S 325$ 
Brasil

$C C / 1916$

artigos 106 a 113

artigos 106 e 107

artigo 107

artigo 109

artigo 145

artigo 147

artigo $816, \S \S 2^{\circ}$ e $3^{\circ}$

artigo 824

artigo 1.396

artigo 1.407

artigo 1.491

artigo 1.554

\section{Código Comercial}

artigo 350

artigo 261

Código de Processo Civil e Comercial do Rio Grande do Sul (Lei n. ${ }^{\circ}$ 65/1908)

artigo 957

artigo 965

artigo $984,1^{\circ}$ e $2^{\circ}$

Código de Processo Civil e Comercial para o Distrito Federal (Decreto n. ${ }^{\circ}$ 16.752/1924)

artigo 903, VI

artigo 969 , I-IV

artigo 969, IV

Código do Processo Civil de Minas Gerais (Lei n. ${ }^{\circ}$ 830/1922)

artigo 1.289

artigo 1.290

Código do Processo Civil e Comercial do Estado de São Paulo (Lei n. $\left.{ }^{\circ} 2.421 / 1930\right)$

artigo 118 
artigo 119

artigo 949, I

artigo 949, II

artigo 950

artigo 950, parágrafo único

artigo $950, \mathrm{I}$

artigo 950, II

artigo 950, III

artigo 951

artigo $1.119, \S 2^{\circ}$

Código do Processo do Estado da Bahia de 1915

artigo $1.062,6^{\circ}$

artigo $1.063,1^{\circ}, 2^{\circ}$ e $3^{\circ}$

Código Judiciário do Rio de Janeiro (Lei n. $\left.{ }^{o} 1.580 / 1919\right)$

artigo $2.138,3^{\circ}$

artigo $2.139,1^{\circ}, 2^{\circ}$ e $3^{\circ}$

CPC/1939 (Decreto-Lei $n^{\circ} 1.608 / 1939$ )

artigo 50

artigo 166

artigo 196

artigo 292

artigo 284

artigo 888, V

artigo 895

artigo 895, I

artigo 895, II

artigo 895, III

artigo 895, IV

artigo $939, \S 2^{\circ}$

\section{CPC/1973}

artigo $42, \S 3^{\circ}$

artigo 219

artigo 251

artigo 262

artigo 263

artigo 466

artigo 466, parágrafo único, I e III

artigo 475-J 
artigo 475-R

artigo 592, V

artigo 593

artigo 593, I

artigo 593, II

artigo 593, III

artigo 615-A, § $3^{\circ}$

artigo 617

artigo 626

artigo 659

artigo $659, \S 4^{\circ}$

artigo $659, \S 6^{\circ}$

artigo 669

artigo 698

artigo $738, \mathrm{I}$

CTN

artigo 185

Consolidação das Leis Civis de 1855

artigo 348

artigo 349

artigo 926

Consolidação das Leis do Processo Civil de 1876

artigo $1.241, \S 6^{\circ}$

artigo $1.247, \S 4^{\circ}$

artigo $1.247, \S \S 1^{\circ}, 2^{\circ}$ e $3^{\circ}$

$C F / 1891$

$C F / 1934$

Disposições Transitórias

artigo 11

Decreto n. $^{\circ} 169$ A/1890

artigo $3^{\circ}, \S 11$ 
Decreto $n .^{\circ} 370 / 1890$

artigo 201

Decreto $n .^{\circ} 482 / 1846$

Decreto $n .^{\circ} 763 / 1890$

Decreto $n .^{\circ} 848 / 1890$

artigo 246, "f"

artigo 247

Decreto $n .^{\circ} 2.044 / 1908$

artigo 29, IV

Decreto $n .^{\circ} 3.084 / 1898$

artigo 491, "f"

artigo 493

Decreto $n .^{\circ} 3.453 / 1865$

artigo 123

artigo 136, § 10

artigo 224

Decreto $n .^{\circ} 4.857 / 1939$

artigo 179

artigo 274

artigo 280

artigo 281

Decreto . $^{\circ}$ 5.746/1929

artigo $55, \mathrm{n}^{\circ} 7$

Decreto $n^{\circ} 18.542 / 1928$ 
artigo 258

artigos 266

artigo 267

artigo 173, IV, VI e VII

Decreto $n .^{\circ} 22.866 / 1933$

$\operatorname{artigo} 2^{\circ}$

Decreto $n .^{\circ} 93.240 / 1986$

artigo $1^{\circ}$

artigo $1^{\circ}$, IV

$\operatorname{artigo} 2^{\circ}$

Decreto Legislativo $n .^{\circ} 4.827 / 1924$

artigo $5^{\circ}, \mathrm{V}$

artigo $5^{\circ}$, VII e VIII

Decreto-Lei $n .^{\circ} 7.661 / 1945$

artigo 52, VII

Lei $.^{\circ} 317 / 1843$

artigo 35

Lei $n^{\circ} 1.237 / 1864$

$\operatorname{artigo} 3, \S \S 1^{\circ}, 2^{\circ}$ e 12

Lei $n^{\circ} 3.272 / 1885$

$\operatorname{artigo} 7^{\circ}$

Lei $.^{\circ} 6.015 / 1973$

artigo 167

artigo 167, I, 2

artigo 167, I, 5 
artigo 167, I, 21

artigo 169

artigo 240

artigo 245

Lei $n .^{\circ} 7.433 / 1985$

$\operatorname{artigo} 1^{\circ}, \S \S 2^{\circ}$ e $3^{\circ}$

Lei $n .^{\circ} 8.935 / 1994$

Lei $n^{\circ} 8.953 / 1994$

Lei $.^{\circ} 10.444 / 2002$

Lei $.^{\circ} 11.382 / 2006$

Lei $.^{\circ} 11.419 / 2006$

Projecto do Codigo do Processo Civil e Commercial do Estado de São Paulo artigo 1.325

Projeto do Código de Processo Civil e Comercial dos Estados Unidos do Brasil artigos 888 a 893

artigo 1.118

Regulamento 737/1850

artigo 60

artigo 62

artigo $492, \S 6^{\circ}$

artigo $494, \S \S 1^{\circ}$ a $3^{\circ}$

\section{Itália}

$C C$ 
artigo 555

\section{Portugal}

CPC

artigo 838, n. 3

Decreto $n .^{\circ} 329-A / 95$

Decreto n. $^{\circ}$ 375-A/99 